UNIVERSIDADE ESTADUAL PAULISTA “JÚLIO DE MESQUITA FILHO” FACULDADE DE CIÊNCIAS AGRONÔMICAS CÂMPUS DE BOTUCATU

CRESCIMENTO, PRODUTIVIDADE, ACÚMULO E EXPORTAÇÃO DE NUTRIENTES EM CULTIVARES DE BATATA (Solanum tuberosum L.)

\author{
ADALTON MAZETTI FERNANDES
}

Dissertação apresentada à Faculdade de Ciências Agronômicas da UNESP - Câmpus de Botucatu, para obtenção do título de Mestre em Agronomia (Agricultura)

BOTUCATU-SP

Fevereiro - 2010 
UNIVERSIDADE ESTADUAL PAULISTA “JÚLIO DE MESQUITA FILHO” FACULDADE DE CIÊNCIAS AGRONÔMICAS CÂMPUS DE BOTUCATU

\section{CRESCIMENTO, PRODUTIVIDADE, ACÚMULO E EXPORTAÇÃO DE NUTRIENTES EM CULTIVARES DE BATATA (Solanum tuberosum L.)}

\section{ADALTON MAZETTI FERNANDES}

Orientador: Prof. Dr. Rogério Peres Soratto

Dissertação apresentada à Faculdade de Ciências Agronômicas da UNESP - Câmpus de Botucatu, para obtenção do título de Mestre em Agronomia (Agricultura)

BOTUCATU-SP

Fevereiro - 2010 
FICHA CATALOGRÁFICA ELABORADA PELA SEÇÃO TÉCNICA DE AQUISIÇÃO E TRATAMENTO DA INFORMAÇÃO - SERVIÇO TÉCNICO DE BIBLIOTECA E DOCUMENTAÇÃ̃O - UNESP - FCA - LAGEADO - BOTUCATU (SP)

Fernandes, Adalton Mazetti, 1982-

Crescimento, produtividade, acúmulo e exportação de nutrientes em cultivares de batata (Solanum tuberosum I.)

/ Adalton Mazetti Fernandes. - Botucatu : [s.n.], 2010. xii, $144 \mathrm{f}$ : tabs., gráfs., fots. color.

Dissertação (Mestrado) - Universidade Estadual Paulista, Faculdade de Ciências Agronômicas, Botucatu, 2010 Orientador: Rogério Peres Soratto Inclui bibliografia.

1. Solanum tuberosum. 2. Análise de crescimento. 3. Exportação de nutrientes. 4. Absorção de nutrientes. 5. Nutrição mineral. I. Soratto, Rogério Peres. II. Universidade Estadual Paulista "Júlio de Mesquita Filho" (Campus de Botucatu). Faculdade de Ciências Agronômicas. III. Título. 
UNIVERSIDADE ESTADUAL PAULISTA "JÚLIO DE MESQUTTA FILHO" FACULDADE DE CIÊNCIAS AGRONÔMICAS

CAMPUS DE BOTUCATU

\section{CERTIFICADO DE APROVAÇĀO}

TITULO CRESCIMENTO, PRODUTIVIDADE, ACÚMULO E EXPORTACÃO DE NUTRIENTES EM CULTIVARES DE BATATA (Solanum tuberosum L.)

ALUNO: ADALTON MAZETTI FERNANDES

ORIENTADOR: PROF DR. ROGÉRIO PERES SORATTO

Aprovado pela Comissão Examinadora

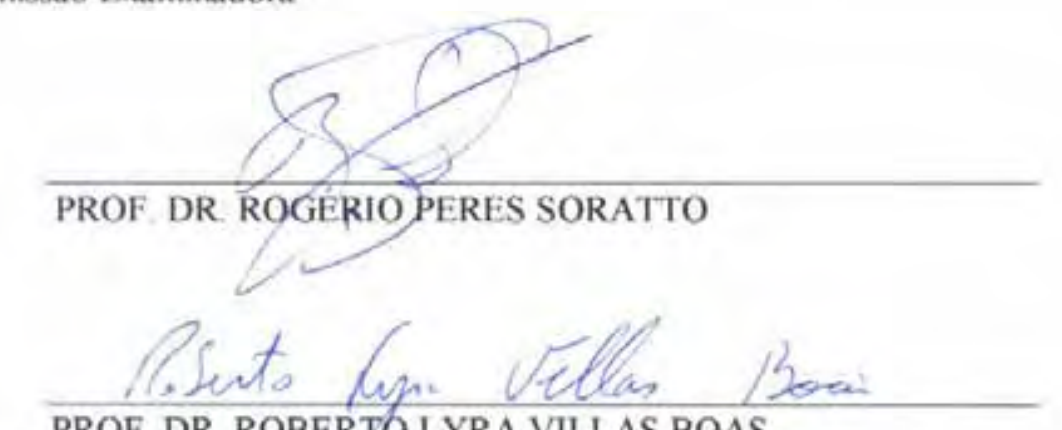

PROF. DR. ROBERTO LYRA VILLAS BOAS

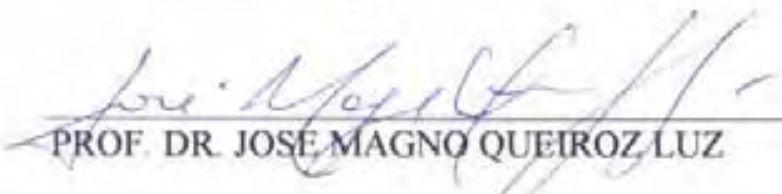

Data da Realização: 08 de fevereiro de 2010 
Ofereço aos meus pais Anísio Fernandes e Marlene Mazetti Fernandes, pela educação e por tudo que fizeram e continuam fazendo por mim.

Dedico à minha noiva Selma Rodrigues da Mota pela convivência agradável, generosidade e amparo nos momentos pessoais mais difíceis. 


\section{AGRADECIMENTOS}

A Deus pela preciosidade da vida.

Ao Conselho Nacional de Desenvolvimento Científico e Tecnológico (CNPQ), pela concessão da bolsa de mestrado.

Ao prof. Dr. Rogério Peres Soratto pela atenção, pelos valiosos ensinamentos, pela paciência e pela orientação que me deram suporte para a realização deste trabalho.

Ao Grupo Ioshida pela concessão da área e por todo o suporte logístico para condução do experimento.

Ao produtor Tadashi Takaku pelo fornecimento dos tubérculossemente das cultivares Atlantic e Markies.

À Associação Brasileira da Batata (ABBA) pelo auxílio financeiro que permitiu a realização das análises laboratoriais.

Ao colega Genivaldo D. de Souza-Schlick pelo auxílio nas coletas de dados no campo e processamento das amostras.

À estagiária Beatrice Luciana Silva e aos agora alunos de pósgraduação Susiane, Lucas e Suelen pelo auxílio nas coletas e processamento de amostras.

A todo o corpo docente da pós-graduação pelos conhecimentos divididos.

Aos funcionários da biblioteca pela atenção.

Aos funcionários do Departamento de Produção Vegetal, pelo auxílio direto e indireto, que permitiu a realização deste trabalho.

A todos aqueles que colaboraram direta ou indiretamente na realização deste trabalho. 


\section{SUMÁRIO}

Página

LISTA DE TABELAS ….................................................................................. VII

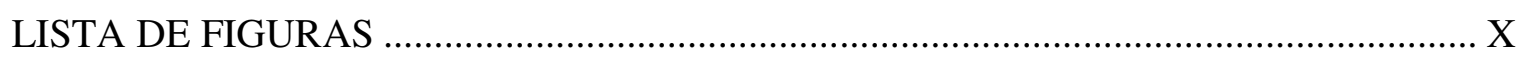

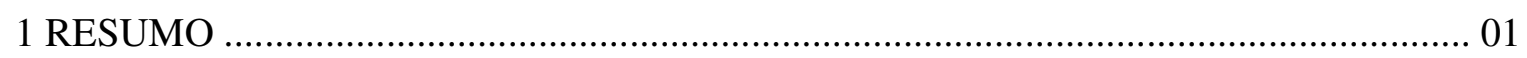

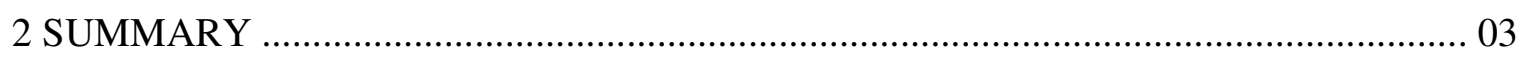

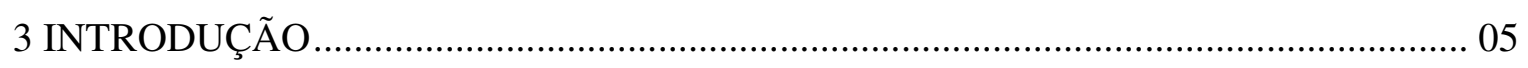

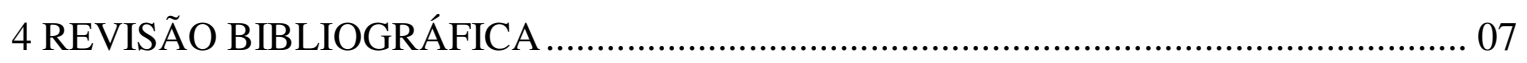

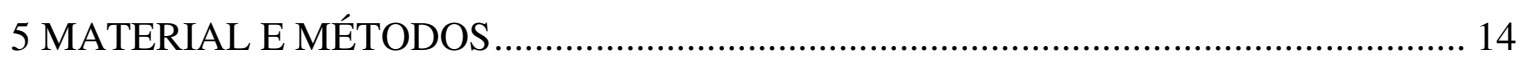

5.1 Caracterização da área experimental e condução do experimento............................... 14

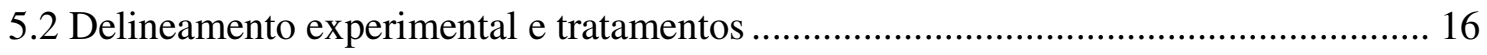

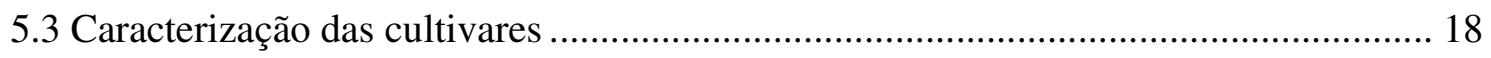

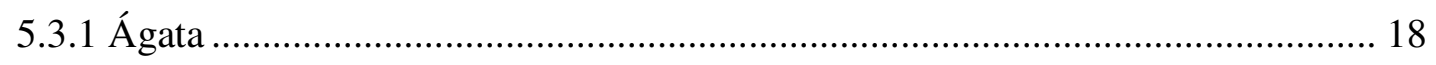

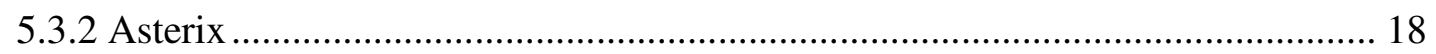

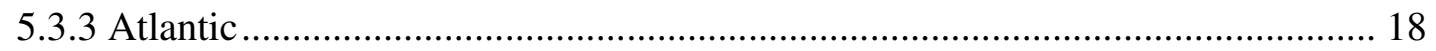

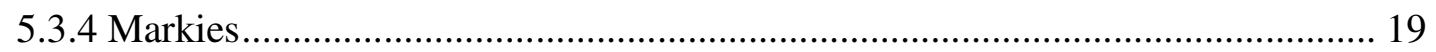

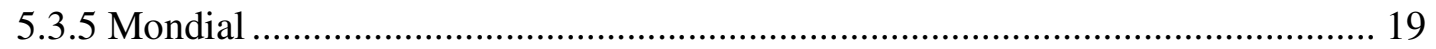

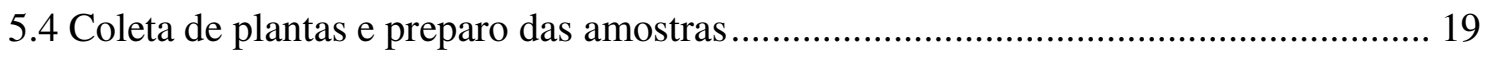

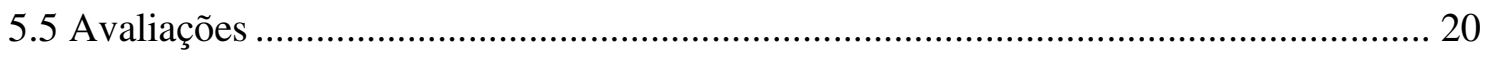

5.5.1 Número médio de hastes por planta e comprimento da maior haste................... 20

5.5.2 Número médio de folhas na maior haste e por planta....................................... 21

5.5.3 Número e massa fresca de tubérculos ............................................................... 21

5.5.4 Acúmulo de massa de matéria seca.................................................................. 21

5.5.5 Taxa de acúmulo massa de matéria seca............................................................ 21

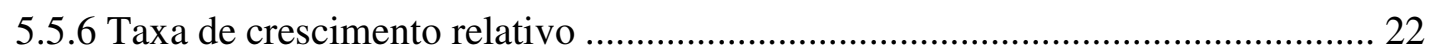

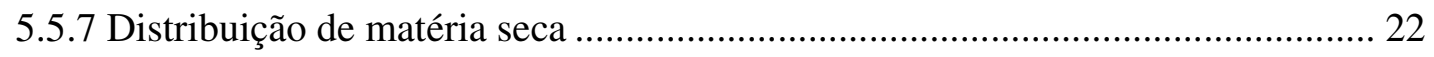

5.5.8 Produtividade e classificação dos tubérculos produzidos ................................... 22

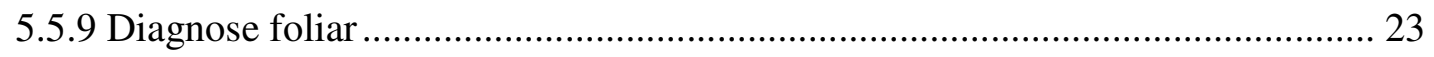

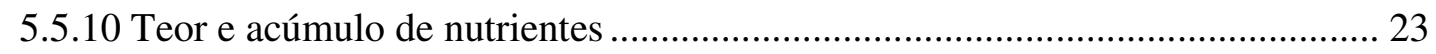

5.5.11 Porcentagem e taxa de absorção de nutrientes ................................................... 23

5.5.12 Porcentagem de matéria seca e exportação de nutrientes .................................. 24 


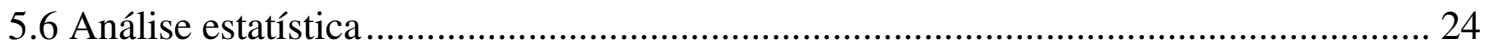

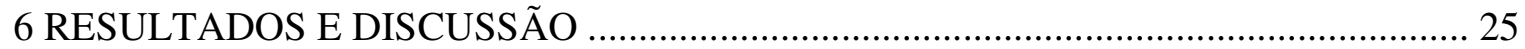

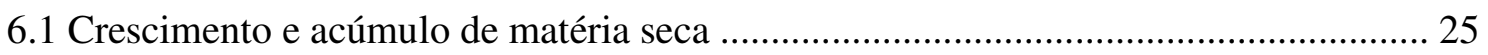

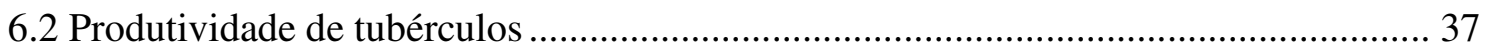

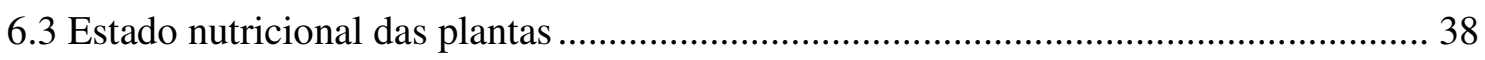

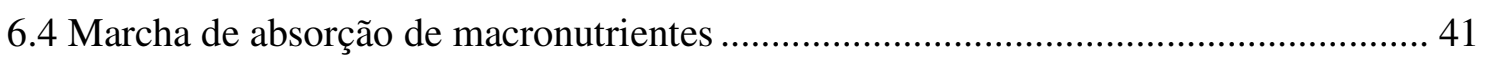

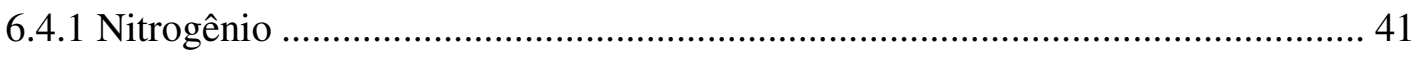

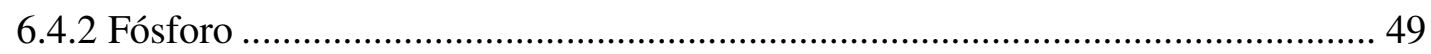

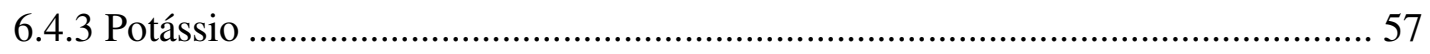

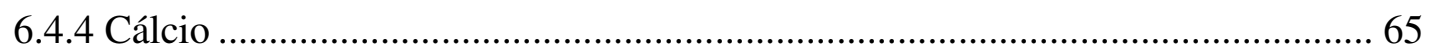

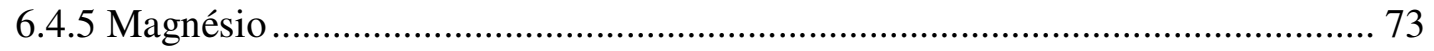

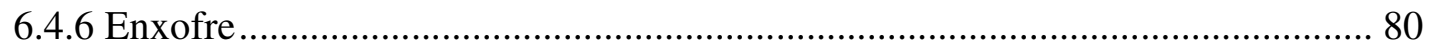

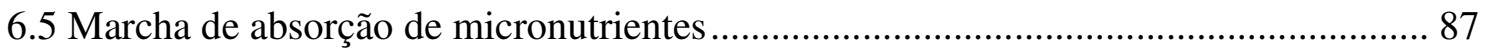

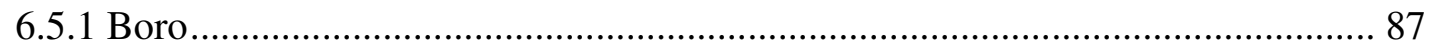

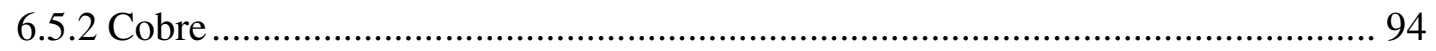

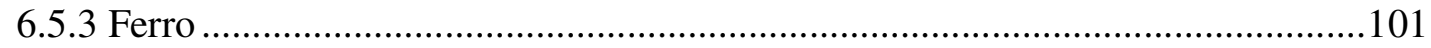

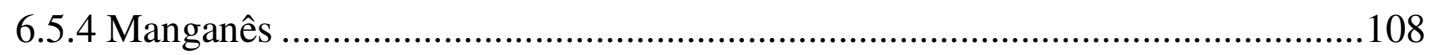

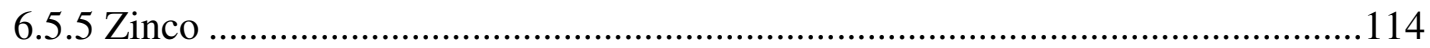

6.6 Porcentagem de matéria seca e exportação de nutrientes .........................................121

6.7 Relações entre crescimento, marcha de absorção e prática de adubação.....................126

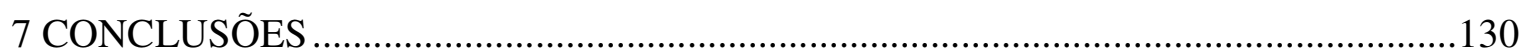

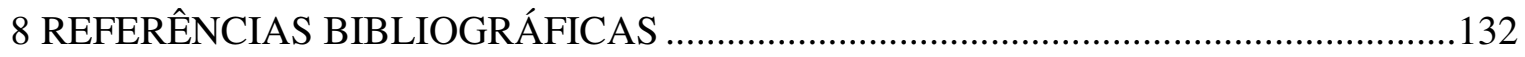

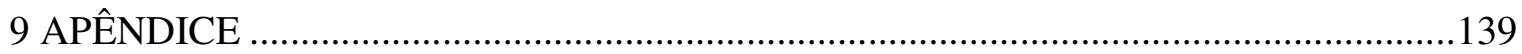




\section{LISTA DE TABELAS}

\section{Tabela}

Página

1 Atributos químicos do solo nas profundidades de 0-0,20 e 0,20-0,40 m antes da instalação do experimento. Estância Lago - Grupo Ioshida, 2008

2 Tratamentos fitossanitários empregados em cultivares de batata. Estância Lago Grupo Ioshida, 2008

3 Porcentagem de MS em cada órgão das plantas, em relação à MS total das plantas de cultivares de batata ao longo do ciclo.

4 Quantidade máxima de MS acumulada, taxa diária máxima de acúmulo e época de maior taxa de acúmulo de MS nos tubérculos e nas plantas de cultivares de batata.

5 Produtividade total, comercial e por classes (especial, primeira, segunda e miúda) de tubérculos das cultivares de batata na safra de inverno 38

6 Teores foliares dos nutrientes N, P, K, Ca, Mg, S, B, Cu, Fe, Mn e Zn, aos 30 dias após a emergência, de cultivares de batata

7 Teor de $\mathrm{N}$ em cada parte das plantas de cultivares de batata ao longo do ciclo da cultura

8 Quantidade máxima de $\mathrm{N}$ acumulada, taxa diária máxima de acúmulo e época de maior taxa de acúmulo de $\mathrm{N}$ nos tubérculos e nas plantas de cultivares de batata

9 Percentual de $\mathrm{N}$ acumulado pelas plantas em cada fase do desenvolvimento das cultivares de batata (valores obtidos das equações ajustadas)

10 Teor de $\mathrm{P}$ em cada parte das plantas de cultivares de batata durante o ciclo da cultura

11 Quantidade máxima de $\mathrm{P}$ acumulada, taxa diária máxima de acúmulo e época de maior taxa de acúmulo de $\mathrm{P}$ nos tubérculos e nas plantas de cultivares de batata

12 Percentual de $\mathrm{P}$ acumulado pelas plantas em cada fase do desenvolvimento das cultivares de batata (valores obtidos das equações ajustadas)

13 Teor de $\mathrm{K}$ em cada parte das plantas de cultivares de batata durante o ciclo da cultura

14 Quantidade máxima de $\mathrm{K}$ acumulada, taxa diária máxima de acúmulo e época de maior taxa de acúmulo de $\mathrm{K}$ nos tubérculos e nas plantas de cultivares de batata 
Tabela

Página

15 Percentual de $\mathrm{K}$ acumulado pelas plantas em cada fase do desenvolvimento das cultivares de batata (valores obtidos das equações ajustadas).

16 Teor de Ca em cada parte das plantas de cultivares de batata durante o ciclo da cultura

17 Quantidade máxima de Ca acumulada, taxa diária máxima de acúmulo e época de maior taxa de acúmulo de Ca nos tubérculos e nas plantas de cultivares de batata

18 Percentual de $\mathrm{Ca}$ acumulado pelas plantas em cada fase do desenvolvimento das cultivares de batata (valores obtidos das equações ajustadas).

19 Teor de Mg em cada parte das plantas de cultivares de batata durante o ciclo da cultura

20 Quantidade máxima de $\mathrm{Mg}$ acumulada, taxa diária máxima de acúmulo e época de maior taxa de acúmulo de $\mathrm{Mg}$ nos tubérculos e nas plantas de cultivares de batata

21 Percentual de $\mathrm{Mg}$ acumulado pelas plantas em cada fase do desenvolvimento das cultivares de batata (valores obtidos das equações ajustadas).

22 Teor de $\mathrm{S}$ em cada parte das plantas de cultivares de batata durante o ciclo da cultura

23 Quantidade máxima de $\mathrm{S}$ acumulada, taxa diária máxima de acúmulo e época de maior taxa de acúmulo de $\mathrm{S}$ nos tubérculos e nas plantas de cultivares de batata

24 Percentual de S acumulado pelas plantas em cada fase do desenvolvimento das cultivares de batata (valores obtidos das equações ajustadas).

25 Teor de B em cada parte das plantas de cultivares de batata durante o ciclo da cultura

26 Quantidade máxima de B acumulada, taxa diária máxima de acúmulo e época de maior taxa de acúmulo de B nos tubérculos e nas plantas de cultivares de batata

27 Percentual de B acumulado pelas plantas em cada fase do desenvolvimento das cultivares de batata (valores obtidos das equações ajustadas).

28 Teor de $\mathrm{Cu}$ em cada parte das plantas de cultivares de batata durante o ciclo da cultura 
29 Quantidade máxima de $\mathrm{Cu}$ acumulada, taxa diária máxima de acúmulo e época de maior taxa de acúmulo de $\mathrm{Cu}$ nos tubérculos e nas plantas de cultivares de batata

30 Percentual de $\mathrm{Cu}$ acumulado pelas plantas em cada fase do desenvolvimento das cultivares de batata (valores obtidos das equações ajustadas).

31 Teor de Fe em cada parte das plantas de cultivares de batata durante o ciclo da cultura

32 Quantidade máxima de Fe acumulada, taxa diária máxima de acúmulo e época de maior taxa de acúmulo de Fe nos tubérculos e nas plantas de cultivares de batata

33 Percentual de Fe acumulado pelas plantas em cada fase do desenvolvimento das cultivares de batata (valores obtidos das equações ajustadas).

34 Teor de Mn em cada parte das plantas de cultivares de batata durante o ciclo da cultura

35 Quantidade máxima de Mn acumulada, taxa diária máxima de acúmulo e época de maior taxa de acúmulo de Mn nos tubérculos e nas plantas de cultivares de batata

36 Percentual de Mn acumulado pelas plantas em cada fase do desenvolvimento das cultivares de batata (valores obtidos das equações ajustadas).

37 Teor de $\mathrm{Zn}$ em cada parte das plantas de cultivares de batata durante o ciclo da cultura

38 Quantidade máxima de Zn acumulada, taxa diária máxima de acúmulo e época de maior taxa de acúmulo de $\mathrm{Zn}$ nos tubérculos e nas plantas de cultivares de batata

39 Percentual de $\mathrm{Zn}$ acumulado pelas plantas em cada fase do desenvolvimento das cultivares de batata (valores obtidos das equações ajustadas).

40 Porcentagem de MS e teor de macronutrientes nos tubérculos de cultivares de batata na colheita final

41 Exportação por área e por tonelada de tubérculos dos macronutrientes N, P, K, $\mathrm{Ca}, \mathrm{Mg}$ e $\mathrm{S}$ nas cultivares de batata na colheita final

42 Teor, exportação por área e por tonelada de tubérculos dos micronutrientes $\mathrm{B}, \mathrm{Cu}$, $\mathrm{Fe}, \mathrm{Mn}$, e $\mathrm{Zn}$ nas cultivares de batata na colheita final 


\section{LISTA DE FIGURAS}

\section{Figura}

Página

1 Precipitação pluvial, irrigação, temperaturas máximas e mínimas registradas na área experimental durante o período de junho a outubro de 2008

2 Número de hastes por planta (A) e comprimento da maior haste (B) de cultivares de batata ao longo do ciclo.

3 Número de folhas na maior haste (A) e número de folhas por planta (B) de cultivares de batata ao longo do ciclo.

4 Número de tubérculos por planta (A), massa fresca média de tubérculos (B), massa fresca de tubérculos por planta $(\mathrm{C})$ e massa fresca de tubérculos por área (D) de cultivares de batata ao longo do ciclo. 28

5 Quantidade de MS nos tubérculos-semente (A), raízes (B), hastes (C), folhas (D), tubérculos (E) e na planta inteira (F) de cultivares de batata ao longo do ciclo. 30

6 Taxa de acúmulo de MS nos tubérculos (A) e na planta inteira (B) de cultivares de batata ao longo do ciclo.

7 Taxa de crescimento relativo de plantas cultivares de batata ao longo do ciclo 36

8 Quantidade de N nos tubérculos-semente (A), raízes (B), hastes (C), folhas (D), tubérculos (E) e na planta inteira (F) de cultivares de batata ao longo do ciclo.

9 Taxa de acúmulo de $\mathrm{N}$ nos tubérculos (A) e nas plantas (B) de cultivares de batata ao longo do ciclo

10 Quantidade de P nos tubérculos-semente (A), raízes (B), hastes (C), folhas (D), tubérculos (E) e na planta inteira (F) de cultivares de batata ao longo do ciclo.

11 Taxa de acúmulo de $\mathrm{P}$ nos tubérculos (A) e nas plantas (B) de cultivares de batata ao longo do ciclo

12 Quantidade de K nos tubérculos-semente (A), raízes (B), hastes (C), folhas (D), tubérculos $(\mathrm{E})$ e na planta inteira $(\mathrm{F})$ de cultivares de batata ao longo do ciclo.

13 Taxa de acúmulo de K nos tubérculos (A) e nas plantas (B) de cultivares de batata ao longo do ciclo 
Figura

Página

14 Quantidade de Ca nos tubérculos-semente (A), raízes (B), hastes (C), folhas (D), tubérculos $(\mathrm{E})$ e na planta inteira $(\mathrm{F})$ de cultivares de batata ao longo do ciclo...

15 Taxa de acúmulo de Ca nos tubérculos (A) e nas plantas (B) de cultivares de batata ao longo do ciclo

16 Quantidade de Mg nos tubérculos-semente (A), raízes (B), hastes (C), folhas (D), tubérculos $(\mathrm{E})$ e na planta inteira $(\mathrm{F})$ de cultivares de batata ao longo do ciclo.

17 Taxa de acúmulo de $\mathrm{Mg}$ nos tubérculos (A) e nas plantas (B) de cultivares de batata ao longo do ciclo

18 Quantidade total de S nos tubérculos-semente (A), raízes (B), hastes (C), folhas (D), tubérculos (E) e na planta inteira (F) de cultivares de batata ao longo do ciclo

19 Taxa de acúmulo de $\mathrm{S}$ nos tubérculos (A) e nas plantas (B) de cultivares de batata ao longo do ciclo

20 Quantidade de B nos tubérculos-semente (A), raízes (B), hastes (C), folhas (D), tubérculos $(\mathrm{E})$ e na planta inteira $(\mathrm{F})$ de cultivares de batata ao longo do ciclo.

21 Taxa de acúmulo de B nos tubérculos (A) e nas plantas (B) de cultivares de batata ao longo do ciclo.

22 Quantidade de $\mathrm{Cu}$ nos tubérculos-semente (A), raízes (B), hastes (C), folhas (D), tubérculos $(\mathrm{E})$ e na planta inteira $(\mathrm{F})$ de cultivares de batata ao longo do ciclo.

23 Taxa de acúmulo de $\mathrm{Cu}$ nos tubérculos (A) e nas plantas (B) de cultivares de batata ao longo do ciclo

24 Quantidade de Fe nos tubérculos-semente (A), raízes (B), hastes (C), folhas (D), tubérculos (E) e na planta inteira $(\mathrm{F})$ de cultivares de batata ao longo do ciclo.

25 Taxa de acúmulo de Fe nos tubérculos (A) e nas plantas (B) de cultivares de batata ao longo do ciclo

26 Quantidade de Mn nos tubérculos-semente (A), raízes (B), hastes (C), folhas (D), tubérculos (E) e na planta inteira $(\mathrm{F})$ de cultivares de batata ao longo do ciclo.

27 Taxa de acúmulo de Mn nos tubérculos (A) e nas plantas (B) de cultivares de batata ao longo do ciclo 
Figura

Página

28 Quantidade de Zn nos tubérculos-semente (A), raízes (B), hastes (C), folhas (D), tubérculos $(\mathrm{E})$ e na planta inteira $(\mathrm{F})$ de cultivares de batata ao longo do ciclo. 116

29 Taxa de acúmulo de Zn nos tubérculos (A) e nas plantas (B) de cultivares de batata ao longo do ciclo 


\section{RESUMO}

A cultura da batata tem grande importância para o Brasil e para o Estado de São Paulo. Porém, apesar de sua importância, falta maiores informações sobre a fisiologia e nutrição mineral desta cultura, limitando a obtenção de elevadas produtividades, com alta qualidade e baixo custo de produção, já que as peculiaridades de cada cultivar podem fazer grande diferença no manejo. Além disso, as doses de fertilizantes normalmente utilizadas na cultura da batata são elevadas, o que gera grande impacto no custo de produção e riscos ambientais. Assim, para obtenção da máxima eficiência produtiva, faz-se necessário o conhecimento do desenvolvimento da planta e da absorção e acumulação de nutrientes nas diferentes fases de desenvolvimento. O objetivo deste trabalho foi avaliar o crescimento, acúmulo de nutrientes durante o ciclo, produtividade de tubérculos e exportação de nutrientes em cinco cultivares de batata. O delineamento experimental utilizado foi o de blocos casualizados, em esquema de parcela subdividida, com quatro repetições. As parcelas foram constituídas pelas cultivares (Ágata, Asterix, Atlantic, Markies e Mondial) e as subparcelas por épocas de coletas de plantas, que foram realizadas a cada 7 dias após a emergência até a colheita final. Cada parcela foi constituída por 10 linhas de $10 \mathrm{~m}$ de comprimento. Todas as cultivares tiveram crescimento lento até o início da fase de enchimento de tubérculos. Desta época até o final do ciclo ocorreu o desenvolvimento dos tubérculos, com a máxima taxa de acúmulo de MS concentrando-se no início dessa fase. A cultivar Mondial foi mais tardia em acumular MS, apresentando as maiores taxas de crescimento na fase final do ciclo. 
As cultivares Ágata, Atlantic e Markies apresentam crescimento semelhante durante todo o ciclo, porém dentre elas, a cultivar Ágata foi mais produtiva. As cultivares Asterix e Mondial apresentaram maior acúmulo de MS, maior produtividade de tubérculos e maior extração de nutrientes do solo. A cultivar Asterix apresentou alta extração e exportação de nutrientes, enquanto, a cultivar Mondial obteve alta extração, porém, menor exportação de nutrientes quando comparada à Ágata. A época de maior taxa de absorção de nutrientes em todas as cultivares ocorreu no início da fase de enchimento de tubérculos, coincidindo, com a época de máxima taxa de produção de MS. Os nutrientes $\mathrm{Cu}$ e $\mathrm{Zn}$ foram mais absorvidos na fase final de enchimento de tubérculos e durante a fase de maturação. A seqüência de extração de nutrientes em todas as cultivares foi: $\mathrm{K}\left(204 \mathrm{~kg} \mathrm{ha}^{-1}\right)>\mathrm{N}\left(102 \mathrm{~kg} \mathrm{ha}^{-1}\right)>\mathrm{Ca}\left(41 \mathrm{~kg} \mathrm{ha}^{-1}\right)>\mathrm{P}$ $\left(16 \mathrm{~kg} \mathrm{ha}^{-1}\right)>\operatorname{Mg}\left(11 \mathrm{~kg} \mathrm{ha}^{-1}\right)>\mathrm{S}\left(8 \mathrm{~kg} \mathrm{ha}^{-1}\right)>\mathrm{Fe}\left(1.885 \mathrm{~g} \mathrm{ha}^{-1}\right)>\mathrm{Mn}\left(540 \mathrm{~g} \mathrm{ha}^{-1}\right)>\mathrm{Zn}(335 \mathrm{~g}$ $\left.\mathrm{ha}^{-1}\right)>\mathrm{Cu}\left(101 \mathrm{~g} \mathrm{ha}^{-1}\right)>\mathrm{B}\left(58 \mathrm{~g} \mathrm{ha}^{-1}\right)$. A seqüência de exportação de nutrientes nas cultivares Ágata, Asterix e Atlantic foi: K $\left(176 \mathrm{~kg} \mathrm{ha}^{-1}\right)>\mathrm{N}\left(67 \mathrm{~kg} \mathrm{ha}^{-1}\right)>\mathrm{P}\left(13 \mathrm{~kg} \mathrm{ha}^{-1}\right)>\mathrm{Mg}(7 \mathrm{~kg} \mathrm{ha}$ $\left.{ }^{1}\right)>\mathrm{S}\left(5 \mathrm{~kg} \mathrm{ha}^{-1}\right)>\mathrm{Ca}\left(2 \mathrm{~kg} \mathrm{ha}^{-1}\right)>\mathrm{Fe}\left(282 \mathrm{~g} \mathrm{ha}^{-1}\right)>\mathrm{Zn}\left(121 \mathrm{~g} \mathrm{ha}^{-1}\right)>\mathrm{Mn}\left(50 \mathrm{~g} \mathrm{ha}^{-1}\right)>\mathrm{B}(38$ $\left.\mathrm{g} \mathrm{ha}^{-1}\right)>\mathrm{Cu}\left(27 \mathrm{~g} \mathrm{ha}^{-1}\right)$. Nas cultivares Markies e Mondial o $\mathrm{Cu}\left(67 \mathrm{~g} \mathrm{ha}^{-1}\right)$ foi mais exportado que o B $\left(30 \mathrm{~g} \mathrm{ha}^{-1}\right)$. 
GROWTH, YIELD, ACCUMULATION AND EXPORTATION OF NUTRIENTS IN POTATO CULTIVARS (Solanum tuberosum L.). Botucatu, 2010. 144p. Dissertação (Mestrado em Agronomia/Agricultura) - Faculdade de Ciências Agronômicas, Universidade Estadual Paulista.

Author: ADALTON MAZETTI FERNANDES

Adviser: ROGÉRIO PERES SORATTO

\section{SUMMARY}

The potato crop has great economical importance for Brazil and São Paulo State. However, despite its importance, it lacks more information about physiology and mineral nutrition of this crop, limiting to obtain high yield, high quality and low production cost, since the peculiarities of each cultivar can make difference in management. Furthermore, the fertilizers rates commonly used in potato crop are high, which has a strong impact on production costs and environmental risks. To get the maximum production efficiency, it is necessary to understand the development of the plant, uptake and accumulation of nutrients in different stages of the plant development. The objective of this study was to evaluate growth, nutrient accumulation, tubers yield and the nutrient exportation in five potato cultivars. The experimental design was the completely randomized block in split-plot with four replications. The plots treatments consisted of potato cultivars (Ágata, Asterix, Atlantic, Markies and Mondial) and subplots were established by harvest time of plants, were carried out every 7 day after emergence to last harvest. Each plot consisted of 10 lines of $10 \mathrm{~m}$ in length. All cultivars showed slow growth until the beginning of the tubers bulking stage. Since this time until the end of the cycle, occurred the tubers development, with maximum dry matter accumulation rate focusing in this initial stage. Mondial cultivar took longer time to accumulate dry matter, presenting the highest growth rates in the final stage of the cycle. Ágata, Atlantic and Markies cultivars, had similar growth throughout the cycle, but among them Agata showed higher 
yield. Mondial and Asterix cultivars had higher dry matter accumulation, higher tubers yield and higher nutrients uptake of soil. Asterix showed high uptake and exportation of nutrients, while Mondial showed high uptake but lower exportation nutrients in contrast to Ágata. The period of greatest rate of nutrients uptake, in all cultivars, occurred in the beginning of tubers bulking stage, coinciding with the time maximum dry matter accumulation rate. $\mathrm{Cu}$ and $\mathrm{Zn}$ showed higher uptake in the final stage of the tubers bulking and during the maturation stage. The sequence of nutrient accumulation, in all cultivars was: $\mathrm{K}\left(204 \mathrm{~kg} \mathrm{ha}^{-1}\right)>\mathrm{N}\left(102 \mathrm{~kg} \mathrm{ha}^{-1}\right)$ $>\mathrm{Ca}\left(41 \mathrm{~kg} \mathrm{ha}^{-1}\right)>\mathrm{P}\left(16 \mathrm{~kg} \mathrm{ha}^{-1}\right)>\mathrm{Mg}\left(11 \mathrm{~kg} \mathrm{ha}^{-1}\right)>\mathrm{S}\left(8 \mathrm{~kg} \mathrm{ha}^{-1}\right)>\mathrm{Fe}\left(1.885 \mathrm{~g} \mathrm{ha}^{-1}\right)>\mathrm{Mn}$ $\left(540 \mathrm{~g} \mathrm{ha}^{-1}\right)>\mathrm{Zn}\left(335 \mathrm{~g} \mathrm{ha}^{-1}\right)>\mathrm{Cu}\left(101 \mathrm{~g} \mathrm{ha}^{-1}\right)>\mathrm{B}\left(58 \mathrm{~g} \mathrm{ha}^{-1}\right)$. The sequence of nutrient exportation in Ágata, Asterix and Atlantic cultivars was: $\mathrm{K}\left(176 \mathrm{~kg} \mathrm{ha}^{-1}\right)>\mathrm{N}\left(67 \mathrm{~kg} \mathrm{ha}^{-1}\right)>\mathrm{P}$ $\left(13 \mathrm{~kg} \mathrm{ha}^{-1}\right)>\operatorname{Mg}\left(7 \mathrm{~kg} \mathrm{ha}^{-1}\right)>\mathrm{S}\left(5 \mathrm{~kg} \mathrm{ha}^{-1}\right)>\mathrm{Ca}\left(2 \mathrm{~kg} \mathrm{ha}^{-1}\right)>\mathrm{Fe}\left(282 \mathrm{~g} \mathrm{ha}^{-1}\right)>\mathrm{Zn}\left(121 \mathrm{~g} \mathrm{ha}^{-}\right.$ $\left.{ }^{1}\right)>\mathrm{Mn}\left(50 \mathrm{~g} \mathrm{ha}^{-1}\right)>\mathrm{B}\left(38 \mathrm{~g} \mathrm{ha}^{-1}\right)>\mathrm{Cu}\left(27 \mathrm{~g} \mathrm{ha}^{-1}\right)$. Markies and Mondial cultivars showed higher exportation of $\mathrm{Cu}\left(67 \mathrm{~g} \mathrm{ha}^{-1}\right)$ than $\mathrm{B}\left(30 \mathrm{~g} \mathrm{ha}^{-1}\right)$.

Keywords: Solanum tuberosum, growth analysis, nutrient uptake, nutrient exportation, mineral nutrition. 


\section{INTRODUÇÃO}

A batata (Solanum tuberosum L.) é uma fonte cada vez mais importante de alimento, sendo fornecedora de proteína de alta qualidade, vitaminas e sais minerais, além de proporcionar energia oriunda dos carboidratos, ocupando o quarto lugar entre os alimentos mais consumidos no mundo, sendo superada apenas pelo trigo, arroz e milho. Além disso, a eficiência produtiva dessa cultura garante elevado aproveitamento de áreas destinadas à produção de alimentos, característica importante num cenário mundial de constante crescimento populacional e insegurança alimentar.

No Estado de São Paulo, o segundo maior produtor do Brasil em 2008, a produção de batata está concentrada nas regiões Nordeste e Sudoeste, onde se destacam os municípios de Vargem Grande do Sul e Itapetininga, respectivamente, regiões nas quais freqüentemente são atingidas produtividades superiores a $30 \mathrm{t} \mathrm{ha}^{-1}$. Nessas regiões o plantio da batata é realizado de fevereiro a agosto, porém, concentrando-se em junho-julho.

A cultura da batata apresenta ciclo relativamente curto e altos rendimentos por área, sendo deste modo muito exigente quanto à presença de nutrientes, na forma prontamente disponível na solução do solo. Assim, no cultivo da batata, normalmente são utilizadas altas doses de fertilizantes inorgânicos, o que torna elevados os custos de produção e os riscos de contaminação ambiental. De forma geral, nos últimos anos tem ocorrido melhoria do material de propagação e incorporação de novas fronteiras de produção, o que tem permitido um melhor aproveitamento dos insumos modernos, contribuindo para o 
aumento da produtividade por área. Entretanto, apesar da sua importância e do grande número de pesquisas sobre a cultura, falta maiores informações na área de fisiologia e nutrição mineral de plantas limitando que o binômio produtividade $\mathrm{x}$ qualidade seja atingido, já que as peculiaridades de cada cultivar fazem grande diferença no manejo e na produtividade da cultura.

A determinação da absorção e do acumulo de nutrientes nas diferentes fases de desenvolvimento da planta é importante, porque permitem determinar as épocas em que os elementos são mais exigidos durante o desenvolvimento da cultura e a distribuição desses nas diferentes estruturas da planta. Assim, a utilização de curvas de acúmulo de nutrientes para as diversas cultivares, como um parâmetro para a recomendação de adubação, é uma boa indicação da necessidade de nutrientes em cada etapa do ciclo de desenvolvimento da planta, indicando as quantidades de nutrientes absorvidas, auxiliando no estabelecimento de um programa de fertilização do solo, visando atingir sua máxima capacidade produtiva, com menor custo e risco ao ambiente. Assim, o objetivo deste trabalho foi avaliar o crescimento, acúmulo de nutrientes durante o ciclo, produtividade de tubérculos e exportação de nutrientes em cinco cultivares de batata. 


\section{REVISÃO BIBLIOGRÁFICA}

A batata, também conhecida como batata inglesa, é uma solanácea anual originária da Cordilheira dos Andes, na América do Sul. O sistema radicular é delicado e superficial, com raízes concentrando-se até $30 \mathrm{~cm}$ de profundidade. Apresenta caules aéreos, herbáceos, e suas raízes originam-se na base desses caules e hastes. Também possui caules subterrâneos adaptados para reserva e reprodução chamados de tubérculos, que é a parte da planta de interesse biológico e econômico (FILGUEIRA, 2000; FORTES; PEREIRA, 2003). A eficiência produtiva da cultura da batata garante elevado aproveitamento de áreas destinadas à produção de alimentos, característica importante num cenário mundial de constante crescimento populacional. A batata é a quarta cultura em importância mundial e a segunda mais largamente distribuída no mundo, ficando atrás somente do milho (BEUKEMA et al., 1990). É cultivada em mais de 125 países, em uma área de 18,5 milhões de hectares, com uma produção de 309 milhões de toneladas em 2007 (FAO, 2009).

No Brasil, a produção de batata em 2009 alcançou 3,4 milhões de toneladas, numa área de 139,4 mil hectares (IBGE, 2009). O estado de São Paulo ocupa uma posição de destaque na produção nacional, sendo o segundo maior produtor no ano de 2008 com produção de 750 mil toneladas, superado apenas por Minas Gerais (AGRIANUAL, 2009). 
A cultura da batata apresenta ciclo relativamente curto, três a quatro meses, com alta produção por área, sendo deste modo muito exigente quanto à presença de nutrientes, na forma prontamente disponível na solução do solo (MAGALHÃES, 1985; FELTRAN, 2005). Além disso, devido aos altos rendimentos, a extração de nutrientes é relativamente alta (REIS JÚNIOR; MONNERAT, 2001). Assim, no cultivo da batata em sistemas intensivos, normalmente são utilizadas altas doses de fertilizantes químicos com $\mathrm{N}, \mathrm{P}$ e K (COGO et al., 2006; SILVA et al., 2007). De acordo com a Anda (2000), a batata é a cultura que apresenta a maior demanda relativa de fertilizantes $\left(1.940 \mathrm{~kg} \mathrm{ha}^{-1}\right)$, cerca de 5,7 vezes maior que a soja, porém, podendo chegar a atingir até $6.000 \mathrm{~kg} \mathrm{ha}^{-1}$ de fertilizantes aplicados em um único cultivo (RIBEIRO, 1999), o que aumenta substancialmente os custos de produção da cultura (SILVA et al., 2000). Segundo a Agrianual (2009), dependendo da época de cultivo, o custo com fertilizantes pode representar mais de $32 \%$ dos custos de produção.

A resposta da batateira à aplicação de fertilizantes varia de acordo com a cultivar, densidade de plantio, cultura antecessora, conteúdo de nutrientes no solo, umidade do solo e manejo da cultura, ou seja, o sistema de produção como um todo. Desta forma, é importante observar o momento adequado para realização das práticas culturais, a precisão e o equilíbrio na quantidade de insumos, fundamentais para obtenção de produtividades satisfatórias (FONTES, 1997a). Além disso, as doses de adubação, a serem fornecidas no decorrer do ciclo, devem ser determinadas considerando-se os critérios de produtividade e sustentabilidade da produção, porque os nutrientes não absorvidos pelas plantas apresentam risco de poluição ambiental (EPPENDORFER; EGGUM, 1994; ANDRIOLO et al., 2006).

$\mathrm{Na}$ literatura brasileira existem trabalhos sobre crescimento de cultivares de batata (GARGANTINI et al., 1963; REIS JÚNIOR; FONTES, 1999; AGUIAR NETTO et al., 2000; OLIVEIRA, 2000; MELO et al., 2003; YORINORI, 2003; FAVORETO, 2005, BARCELOS et al., 2007). A análise do crescimento é tida como método-padrão para se medir a produtividade biológica de uma cultura (MAGALHÃES, 1979). Além disso, ela baseia-se, fundamentalmente, no fato de que cerca de 90\%, em média, da matéria seca (MS) acumulada pelas plantas ao longo do seu desenvolvimento resulta da atividade fotossintética; permitindo avaliar o crescimento final da planta como um todo e a contribuição dos diferentes órgãos no desenvolvimento total (BENINCASA, 2003). Dessa forma, tal análise tem 
permitido avaliar as diferenças de comportamento entre os cultivares utilizados e visa o levantamento de informações fisiológicas que facilitem a tomada de decisões relativas ao manejo da cultura. A análise de crescimento é realizada por meio de avaliações seqüenciais do acúmulo de fitomassa ou de índices fisiológicos dela obtidos (GAVA et al., 2001). Os índices determinados na análise de crescimento indicam a capacidade do sistema assimilatório das plantas em sintetizar (fonte) e alocar a matéria orgânica nos diversos órgãos (drenos) que dependem da fotossíntese, respiração e translocação de fotoassimilados dos sítios de fixação de carbono aos locais de utilização ou de armazenamento, onde ocorrem o crescimento e a diferenciação dos órgãos (FONTES et. al., 2005). Dois índices bastante utilizados para determinar o padrão de crescimento vegetal e que não requerem, para sua avaliação, o conhecimento da área foliar da planta, são a taxa de produção de MS (TPMS) e a taxa de crescimento relativo (TCR), que indicam, respectivamente, o acúmulo de MS em função da área de solo, por unidade de tempo e o acúmulo de MS por unidade de MS presente no início de determinado período (MAGALHÃES, 1979; LUCCHESI, 1984; BEADLE, 1987).

Na batateira, o acúmulo de MS e sua distribuição na planta pode ser dividido em quatro estádios fenológicos, com base no crescimento da parte aérea e dos tubérculos. O Estádio I ou "crescimento vegetativo", tem início com o desenvolvimento dos brotos. Nesse período, a MS acumulada é proveniente do desenvolvimento rápido das raízes e da parte aérea, indo desde a emergência até o início do "inchamento" dos tubérculos. O Estádio II ou "tuberização", dura em média de 10 a 14 dias e tem início com a formação dos tubérculos nas pontas dos estolões, mas eles ainda não estão desenvolvidos. Esse estádio vai até o início do enchimento dos primeiros tubérculos. Embora a formação de tubérculos continue durante o próximo estádio de desenvolvimento, os tubérculos que definirão a colheita formam-se nesse estádio. O estádio III ou "enchimento dos tubérculos", é caracterizado por uma taxa de aumento constante de massa e tamanho dos tubérculos. A parte aérea continua a crescer, porém os aumentos na MS total são, na maior parte, devido aos tubérculos. Este é o estádio mais longo e vai até a maturação. O estádio IV ou "maturação", é marcado pelo início do amarelecimento dos caules, senescência de folhas e redução da taxa de crescimento dos tubérculos. Nessa fase, o aumento da MS dos tubérculos é resultado, principalmente da translocação de materiais a partir da parte aérea e raízes (KLEINKOPF et al. 1981; ROBERTS; DOLE, 1985; OJALA, et al., 1990; BIEMOND; VOS, 1992). 
Estudos realizados por Macedo et al. (1977), demonstraram que de modo geral, as curvas que descrevem a absorção de nutrientes pela batateira segue o padrão da curva de acúmulo de MS. Assim, o estudo sobre o acúmulo de MS e a absorção de nutrientes em função do estádio fenológico da planta fornecem informações para o conhecimento das épocas em que elas absorvem nutrientes em maiores proporções e, ao mesmo tempo, torna-se possível o conhecimento a respeito das épocas mais propícias à adição dos nutrientes, em formas prontamente disponíveis às plantas (MAGGIO, 2006). Embora o acúmulo de MS e de nutrientes sejam afetados por fatores ligados ao genótipo e ao ambiente, de modo geral, os nutrientes são absorvidos em função do ciclo e da translocação na planta (MACEDO JUNIOR, 1998), pois, o acúmulo e a distribuição dos nutrientes na planta dependem de seu estádio de desenvolvimento (MARSCHNER, 1995).

Assim, a utilização de curvas de acúmulo de nutrientes para as diversas cultivares, como um parâmetro para a recomendação de adubação, é uma boa indicação da necessidade de nutrientes em cada etapa do desenvolvimento da planta, indicando as quantidades de nutrientes absorvidas para se atingir certa massa de material seco, auxiliando assim no estabelecimento de um programa de fertilização do solo para a cultura (ROBERTS; DOLE, 1985; VILLAS BÔAS et al., 2001).

Esta importância sobre o conhecimento da marcha de absorção de nutrientes foi ressaltada por Fayad et al. (1998), após verificarem que as curvas de crescimento e de absorção de nutrientes pelo tomateiro, em função da sua idade, fornecem informações de grande importância para um plano de manejo e condução da planta, fertirrigação e adubação.

Embora a marcha de absorção de nutrientes seja afetada por diversos fatores, de modo geral, pode-se dizer que os nutrientes são absorvidos durante todo o ciclo, sendo as diferenças verificadas nas velocidades de absorção destes em função do estádio de desenvolvimento da cultura, como foi demonstrado por Carolus (1937), em experimento utilizando uma cultivar de batata de ciclo vegetativo longo, onde a cultura absorveu somente $9 \%$ da quantidade total dos nutrientes nas primeiras sete semanas de seu ciclo, $16 \%$ da sétima até a nona semana, $67 \%$ da décima até a décima segunda semana e, finalmente, $8 \%$ dos nutrientes restantes, entre a décima terceira e a décima quarta semana.

Assim, é de fundamental importância respeitar as fases de desenvolvimento durante o ciclo da planta e interpretá-las para realizar o manejo da adubação, 
pois, as exigências de cada nutriente variam de acordo com a marcha de absorção. Yorinori (2003) quando avaliou a curva de crescimento e acúmulo de nutrientes pela cultura da batata cv. 'Atlantic' na região de Itapetininga-SP, observou um padrão diferente de absorção do nitrogênio $(\mathrm{N})$ e do potássio $(\mathrm{K})$ na safra das águas e das secas, sendo que na safra das águas o $\mathrm{N}$ apresentou maior acúmulo que o $\mathrm{K}$.

Dessa forma, devido principalmente aos períodos de máxima absorção pela planta é que a exigência das culturas por nutrientes não pode ser inferida somente a partir da extração total, sendo necessário o estudo da marcha de absorção dos nutrientes em função do tempo, para prever como, quando e quanto de adubo deve ser aplicado (DUARTE et al., 2003). Yorinori (2003) observou durante a safra das águas que a cultivar Atlantic chegou a absorver 6,5 $\mathrm{kg} \mathrm{ha}^{-1}$ dia $^{-1}$ de $\mathrm{K}$ entre os 63 e 69 dias após o plantio (DAP), sendo que nesse mesmo período ocorreram as maiores taxas de absorção de $\mathrm{P}$, porém, com valores 10 vezes menores que os obtidos para o K. Estes resultados demonstram a necessidade da alta disponibilidade desses elementos durante esse período, pois, trata-se da época em que se observaram as maiores taxas de absorção.

Estudos realizados por Hawkins (1946) demonstraram que o acúmulo máximo de todos os macronutrientes ocorreu cerca de 10 dias antes de se atingir a produção máxima de material seco e que o maior acúmulo de MS na parte aérea ocorreu entre 61-70 DAP, e para os tubérculos, entre 82-91 DAP. O acúmulo máximo de MS total ocorreu 85 DAP. Além disso, os resultados mostraram que os tubérculos acumularam as maiores quantidades de $\mathrm{N}$, fósforo $(\mathrm{P})$ e enxofre $(\mathrm{S})$ e a parte aérea, as maiores quantidades de cálcio (Ca) e magnésio ( $\mathrm{Mg}$ ). Quanto ao $\mathrm{K}$, o acúmulo foi semelhante, para os tubérculos e a parte aérea.

O trabalho de Gargantini et al. (1963), demonstrou esta variação na absorção de nutrientes pela cultivar 'Bintje' em função do tempo. Estes autores observaram que os períodos de máxima absorção do $\mathrm{N}, \mathrm{K}, \mathrm{Mg}$ e $\mathrm{S}$ foram verificados entre 40 e 50 dias após a emergência, enquanto que o $\mathrm{P}$ e o $\mathrm{Ca}$ foram absorvidos continuamente do início ao final do ciclo, atingindo o acúmulo máximo aos 80 dias após a emergência. Os autores ainda relatam que o maior acúmulo de MS ocorreu aos 70 dias após a emergência, ou seja, após a máxima absorção dos nutrientes. Assim, o acúmulo de MS pode não ser suficiente para se 
determinar com precisão qual a melhor época e quantidade de fertilizantes a se fornecer a cultura.

Além disso, estudos realizados por Macedo et al. (1977) demonstraram diferenças entre as cultivares quanto à época preferencial de absorção de N. Estes autores observaram que das seis cultivares nacionais de batata avaliadas todas apresentaram a época de máxima exigência por $\mathrm{N}$ por volta dos 45 dias após a emergência. No entanto, após esse período as cultivares de ciclo tardio continuaram absorvendo o nutriente em taxas mais elevadas até o final do ciclo.

Através do estudo da marcha de absorção, Yorinori (2003) observou que $20 \%$ de todo o $\mathrm{N}$ extraído pela cultura da batata foi absorvido na tuberização e $60 \%$ no enchimento de tubérculos, durante a safra das águas, ao passo que na safra das secas, esses valores corresponderam a 24 e $76 \%$, respectivamente, confirmando os relatos de Ezeta e McCollum (1972) que demonstraram que para a maioria das cultivares de batata, a quantidade de $\mathrm{N}$ acumulado no início da tuberização foi menor que 50\% do total. Dessa maneira, o estudo da marcha de absorção de nutrientes permite estabelecer os períodos de maior necessidade de elementos essenciais, bem como, as quantidades mínimas que devem ser restituídas ao solo para fins de manutenção da fertilidade. Porém, os valores de extração de nutrientes pela cultura batata, na sua maioria, são bastante variáveis, pois, dependem de diversos fatores, principalmente da produtividade (FONTES, 1997a).

Dessa forma, o conhecimento da quantidade de nutrientes acumulados nas plantas, principalmente na parte colhida, é importante para se avaliar a remoção dos nutrientes da área de cultivo e, tem sido um dos componentes necessários para as recomendações econômicas de adubação. Na literatura tem-se observado algumas variações na quantidade de nutrientes acumulados nos tubérculos da batata, como é relatado no trabalho de Hawkins (1946), onde os tubérculos acumularam as maiores quantidades de N, P e S; enquanto, Feltran e Lemos (2001), observaram em quatro cultivares de batata a seguinte ordem de exportação de nutrientes pelos tubérculos: K, N, P, Mg, Ca, boro (B) e zinco ( $\mathrm{Zn}$ ). Contanto, Paula et al. (1986) observou que os macronutrientes acumulados em maiores quantidades na MS total (parte aérea + tubérculo), em ordem decrescente, foram de $\mathrm{K}, \mathrm{N}, \mathrm{Ca}$, $\mathrm{P}, \mathrm{Mg}$ e $\mathrm{S}$, sendo que os tubérculos acumularam as maiores quantidades de macronutrientes, com exceção do $\mathrm{Ca}$, que teve o maior acúmulo na parte aérea. 
Assim, conhecer sobre a nutrição e o comportamento da cultura da batata durante o crescimento e o desenvolvimento em certos ambientes de cultivo é de suma importância, para que se possa disponibilizar nutrientes de forma prontamente assimiláveis a fim de atingir sua máxima capacidade produtiva (FAVORETTO, 2005).

Pelo fato da batateira ser uma planta que se desenvolve rapidamente, havendo assim, uma grande exigência de nutrientes num curto espaço de tempo, e uma vez que, as informações em relação à marcha de absorção de nutrientes pela cultura são muitas vezes antigas (GARGANTINI et al., 1963; MACEDO et al., 1977; PAULA et al., 1986) ou, quando atuais são restritas a poucas cultivares (YORINORI, 2003), existe a necessidade de se estabelecer a curva de acúmulo de MS e de nutrientes para as cultivares mais importantes, nas principais regiões produtoras, como é a região sudoeste do Estado de São Paulo, visando obter maior eficiência dos fertilizantes utilizados, aumento da produtividade e qualidade da batata produzida, redução dos custos de produção e dos riscos de contaminação ambiental. 


\section{MATERIAL E MÉTODOS}

\subsection{Caracterização da área experimental e condução do experimento}

O experimento foi conduzido no ano agrícola de 2008/09, em uma propriedade pertencente ao Grupo Ioshida - Estância Lago, no município de Itaí (SP), localizada na latitude $23^{\circ} 28^{\prime} 44^{\prime}$ ' S e na longitude $49^{\circ} 08^{\prime} 19^{\prime}$ ' W e com altitude média de 670 m. O Clima da região é Cfa, segundo a classificação de Köppen. Os dados climáticos, temperaturas máximas e mínimas, precipitação e irrigação durante o período de condução do experimento, encontram-se na Figura 1.

O solo do local é um Latossolo Vermelho distrófico (EMBRAPA, 1999). Antes da instalação do experimento foram coletadas amostras de solo da camada de 00,20 e 0,20-0,40 m na área experimental para determinação das características químicas (RAIJ et al., 2001) e granulométricas do solo (EMBRAPA, 1997) (Tabela 1).

A área tinha sido cultivada anteriormente com milho e o preparo do solo para o cultivo da batata foi realizado de forma convencional com a seguinte sequiência de operações: dessecação, roçagem, duas gradagens pesadas, escarificação, aração e uma gradagem leve às vésperas do plantio. Não realizou-se calagem na área experimental e a adubação de plantio foi a mesma utilizada na área comercial do produtor, a qual, constou da aplicação no sulco de $2.100 \mathrm{~kg} \mathrm{ha}^{-1}$ do fertilizante formulado 04-30-10. Juntamente com o 
fertilizante e antes do plantio, aplicaram-se no sulco os inseticidas tiametoxam (148 g do i.a. $\left.\mathrm{ha}^{-1}\right)$ e clorpirifós $\left(1.470 \mathrm{~g}\right.$ do i.a. ha $\left.{ }^{-1}\right)$, e o fungicida pencicuron $\left(516,5 \mathrm{~g}\right.$ do i.a. ha $\left.{ }^{-1}\right)$. $\mathrm{O}$ plantio foi feito manualmente em 08 de junho de 2008, ou seja, na "safra de inverno", utilizando-se o espaçamento de $0,80 \mathrm{~m}$ entre linhas e $0,35 \mathrm{~m}$ entre os tubérculos-semente, visando atingir uma população de 35.714 plantas por hectare.

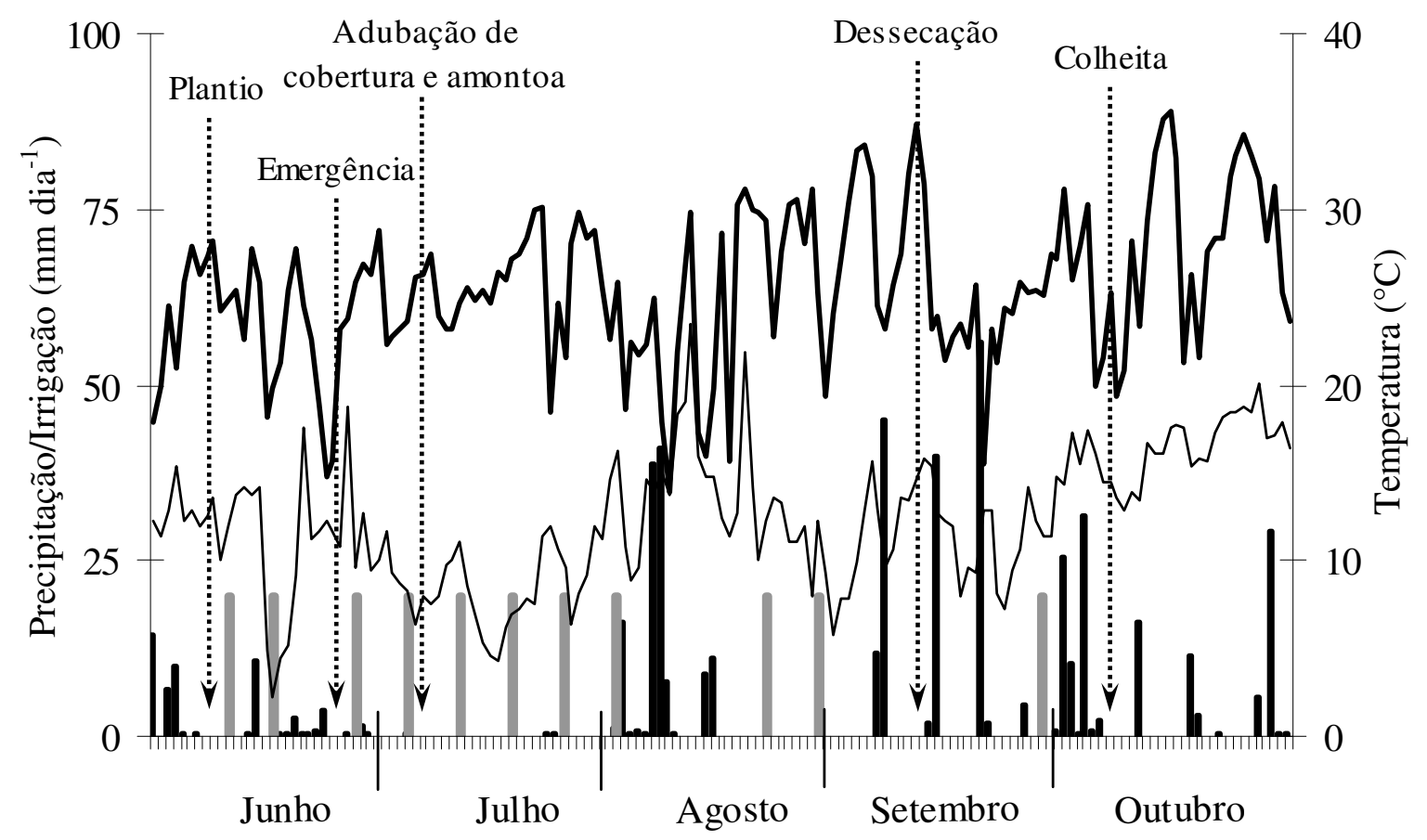

Figura 1. Precipitação pluvial (|), irrigação ( $)$, temperaturas máximas ( $)$ e mínimas ( _ ) registradas na área experimental durante o período de junho a outubro de 2008.

Tabela 1. Atributos químicos do solo nas profundidades de 0-0,20 e 0,20-0,40 m antes da instalação do experimento. Média de quatro repetições.

\begin{tabular}{|c|c|c|c|c|c|c|c|c|c|c|}
\hline Profundidade & $\mathrm{pH}$ & $\mathrm{P}_{\text {resina }}$ & M.O. & $\mathrm{K}$ & $\mathrm{Ca}$ & $\mathrm{Mg}$ & $\mathrm{H}+\mathrm{Al}$ & CTC & SB & $\mathrm{V}$ \\
\hline $\mathrm{m}$ & $\mathrm{CaCl}_{2}$ & $\mathrm{mg} \mathrm{dm}^{-3}$ & $\mathrm{~g} \mathrm{dm}^{-3}$ & & & \multicolumn{3}{|c|}{$-\mathrm{mmol}_{\mathrm{c}} \mathrm{dm}^{-3}$} & & $\%$ \\
\hline $0,0-0,20$ & 4,4 & 71 & 31,8 & 5,6 & 28,6 & 6,1 & 74,7 & 115,1 & 40,4 & 35,1 \\
\hline $0,20-0,40$ & 4,3 & 68 & 32,1 & 4,5 & 25,0 & 4,4 & 78,4 & 112,3 & 33,9 & 30,2 \\
\hline Profundidade & B & $\mathrm{Cu}$ & $\mathrm{Fe}$ & $\mathrm{Mn}$ & $\mathrm{Zn}$ & \multicolumn{2}{|c|}{$\mathrm{S}-\mathrm{SO}_{4}{ }^{2-}$} & Areia & Silte & Argila \\
\hline $\mathrm{m}$ & & & $\mathrm{mg} \mathrm{dm}$ & & & & & & $\mathrm{g} \mathrm{kg}^{-1}$ & \\
\hline $0,0-0,20$ & 2,1 & 1,7 & 32,2 & 17,1 & 3,1 & \multicolumn{2}{|c|}{23,1} & 182 & 268 & 550 \\
\hline $0,20-0,40$ & 2,7 & 1,6 & 34,2 & 17,1 & 2,3 & \multicolumn{2}{|c|}{31,1} & - & - & - \\
\hline
\end{tabular}


Utilizou-se tubérculos-semente certificados, tipo III (diâmetro entre 30 e $40 \mathrm{~mm}$ ) com peso médio de $41 \mathrm{~g}, 48 \mathrm{~g}, 36 \mathrm{~g}, 28 \mathrm{~g}$ e $31 \mathrm{~g}$, respectivamente, para as cultivares Ágata, Asterix, Atlantic, Markies e Mondial. Os tubérculos sementes receberam tratamento com oxitetraciclina+estreptomicina $\left(4,25+22,12 \mathrm{~g}\right.$ do i.a. ha $\left.{ }^{-1}\right)$, mancozebe $(115,7 \mathrm{~g}$ do i.a. ha ${ }^{1}$ ) e pencicuron (361,6 g do i.a. ha $\left.{ }^{-1}\right)$. As emergências das plantas ocorreram aos 18, 17, 17, 19 e 20 DAP para as cultivares Ágata, Asterix, Atlantic, Markies e Mondial, respectivamente. Aos 29 DAP fez-se a aplicação da adubação de cobertura com $227 \mathrm{~kg} \mathrm{ha}^{-1}$ do formulado 2005-20 e, simultâneamente com a operação de amontoa, fez-se a aplicação do fungicida penicurom (516,5 g do i.a. ha $\left.{ }^{-1}\right)$ e do inseticida clorpirifós (1.470,0 g do i.a. ha $\left.{ }^{-1}\right)$.

A irrigação da área experimental foi realizada por sistema de aspersão do tipo convencional, de acordo com as recomendações técnicas para a cultura na região e critérios adotados pelo produtor, visando atender as necessidades hídricas do sistema soloplanta, durante todo o ciclo da cultura, cujas quantidades de água aplicadas encontram-se na Figura 1. O controle fitossanitário foi realizado segundo recomendações técnicas para a cultura e critérios adotados pelo produtor, utilizando-se produtos recomendados para a cultura da batata (Tabela 2).

Aos 97 dias após o plantio foi realizada a dessecação da parte aérea de todas as cultivares de batata com o herbicida diquat (330,6 g do i.a. ha $\left.{ }^{-1}\right)$, e 25 dias após a dessecação (122 DAP) realizou-se a colheita dos tubérculos.

\subsection{Delineamento experimental e tratamentos}

O delineamento experimental utilizado foi o de blocos casualizados, em esquema de parcela subdividida, com quatro repetições. As parcelas foram constituídas por cinco cultivares de batata (Ágata, Asterix, Atlantic, Markies e Mondial) e as subparcelas por épocas de coletas de plantas (avaliações), que foram realizadas no momento do plantio (tubérculos-semente) e aos 20, 27, 34, 41, 48, 55, 62, 69, 76, 83, 90 e 97 DAP. Cada parcela foi constituída por 10 linhas de $10 \mathrm{~m}$ de comprimento. Para as avaliações foram consideradas as linhas centrais desprezando $0,5 \mathrm{~m}$ na extremidade de cada fileira de plantas e uma fileira de cada lado da unidade experimental. 
Tabela 2. Tratamentos fitossanitários empregados em cultivares de batata na safra de inverno. Itaí (SP), 2008.

\begin{tabular}{|c|c|c|}
\hline Dias após o Plantio & Ingrediente ativo & Dose \\
\hline DAP & & g do i.a. ha \\
\hline 3 & parationa-metílica & 247,9 \\
\hline \multirow{2}{*}{11} & metribuzim & 238,0 \\
\hline & parationa-metílica & 247,9 \\
\hline \multirow{3}{*}{23} & chorothalonil & 971,1 \\
\hline & fluazifope-P-butílico & 103,3 \\
\hline & parationa-metílica & 247,9 \\
\hline \multirow{3}{*}{32} & chorothalonil & $1.033,1$ \\
\hline & parationa-metílica & 247,9 \\
\hline & cloridrato de propamocarbe & 924,9 \\
\hline \multirow{3}{*}{39} & mancozeb & $1.983,5$ \\
\hline & abamectina & 11,2 \\
\hline & parationa-metílica & 247,9 \\
\hline \multirow{3}{*}{51} & mancozebe & $1.652,9$ \\
\hline & fenamidone & 148,8 \\
\hline & parationa-metílica & 247,9 \\
\hline \multirow{3}{*}{52} & clorotalonil & 892,6 \\
\hline & parationa-metílica & 247,9 \\
\hline & azoxytrobin & 49,6 \\
\hline \multirow{3}{*}{58} & clorotalonil & 892,6 \\
\hline & cloridrato de propamocarbe & 895,0 \\
\hline & metamidofós & 247,9 \\
\hline \multirow{3}{*}{64} & clorotalonil & 892,6 \\
\hline & tebuconazol & 103,3 \\
\hline & metamidofós & 247,9 \\
\hline \multirow{3}{*}{71} & abamectina & 11,2 \\
\hline & chorothalonil & 826,4 \\
\hline & teflubenzuron & 12,4 \\
\hline \multirow{2}{*}{74} & clorotalonil & 892,6 \\
\hline & metamidofós & 247,9 \\
\hline \multirow{3}{*}{79} & clorotalonil & 892,6 \\
\hline & dimetomorfe & 206,6 \\
\hline & metamidofós & 247,9 \\
\hline \multirow{2}{*}{82} & casugamicina & 24,8 \\
\hline & parationa-metílica & 247,9 \\
\hline \multirow{2}{*}{88} & teflubenzuron & 18,6 \\
\hline & parationa-metílica & 247,9 \\
\hline 97 & parationa-metílica & 247,9 \\
\hline 107 & parationa-metílica & 247,9 \\
\hline
\end{tabular}




\subsection{Caracterização das cultivares}

\subsection{1 Ágata}

Apresenta um alto rendimento, porém, com um teor muito baixo de MS, tendo como uma das suas características maturação precoce. As plantas possuem hastes finas e moderadamente finas com tubérculos ovais; casca amarela e predominantemente lisa, polpa de cor amarelo-claro e olhos superficiais. Apresenta polpa bastante consistente e de cor firme quando cozida, sendo recomendado para o consumo na forma cozida ou assada. É um material susceptível a requeima das folhas (Phytophthora infestans), razoavelmente resistente ao vírus Yn e imune ao cancro (NIVAP, 2007; ABBA, 2009).

\subsubsection{Asterix}

É uma cultivar semi-tardio, de pele vermelha, que apresenta rendimento bastante elevado com produção uniforme e tubérculos ovais-alongados de tamanho médio a grande com polpa amarela. Essa cultivar apresenta uma alta produção e alto teor de MS, sendo bastante resistente ao enegrecimento interno. Apresenta muito boas características tanto para o cozimento quanto para fritas, sendo bastante utilizada industrialmente na fabricação de pré-fritas congeladas em função do seu formato ovalalongado propiciar um ótimo aproveitamento no corte em palitos. É resistente a nematóides e ao cancro (verruga), apresenta boa resistência ao vírus $\mathrm{A}, \mathrm{X}$ e $\mathrm{Yn}$, resistência moderada à sarna comum (Streptomyces spp.) e a requeima (NIVAP, 2007; ABBA, 2009).

\subsubsection{Atlantic}

Possui baixos teores de açúcares redutores e teores altos de sólidos solúveis, características ideais para batata com finalidade industrial, além de possuir um ciclo médio-precoce. As plantas têm de porte médio a alto, ereto e hastes grossas. Os tubérculos apresentam formato oval-arredondado com polpa e película branca, olhos semi-profundos e brotação tardia. Essa cultivar tem potencial de produção mediana, porém, com alta percentagem de tubérculos graúdos e MS, sendo especialmente indicado para o preparo de 
chips e batata-palha. Possui baixa resistência a requeima, suscetibilidade a pinta preta (Alternaria solani S.), resistência ao vírus do mosaico leve (PVX) e sendo suscetível ao vírus do enrolamento da folha (PLRV) e ao vírus do mosaico (PVY) (ELMA CHIPS, 2000; ABBA, 2009).

\subsubsection{Markies}

Apresenta maturação tardia a muito tardia com alta produtividade. As plantas são bastante vigorosas com porte ereto, o que facilita a realização das práticas culturais. Seu ciclo varia de 90 a 100 dias para o completo desenvolvimento dos tubérculos e concentração da MS. Há uma predominância de tubérculos graúdos, com formato ovalalongado, olhos superficiais, pele amarela clara e lisa, atendendo, perfeitamente, às exigências do mercado consumidor. Os tubérculos apresentam um bom teor de MS e equilíbrio entre açúcares redutores e amido, que lhes conferem dupla aptidão de uso, ou seja, boa qualidade após o preparo, tanto na forma de cozimento para atender ao mercado de consumo in natura, como na forma de fritura destinada a fins industriais. Possui uma boa tolerância a requeima (NIVAP, 2007; ABBA, 2009).

\subsubsection{Mondial}

São plantas altas, de rendimento muito alto e com teor mediano a baixo de MS, características que atendem ao mercado de consumo fresco. Possui folhas grandes de desenvolvimento rápido, hastes firmes e semi-eretas, de cor verde escuro. Seus tubérculos são oval-alongados, grandes, com olhos superficiais, casca lisa e cor amarelo. Sua polpa é de cor amarelo claro e quando cozida apresenta-se um pouco farinhenta. É susceptível a requeima das folhas e ao vírus do enrolamento, imune ao cancro; resistente ao nematóide dourado e moderadamente resistente a sarna comum (NIVAP, 2007; ABBA, 2009).

\subsection{Coleta de plantas e preparo das amostras}

As coletas iniciaram-se antes do plantio, coletando-se amostras de 
tubérculos-semente de cada cultivar e, após a emergência, as coletas de plantas foram realizadas semanalmente, ou seja, aos 20, 27, 34, 41, 48, 55, 62, 69, 76, 83, 90 e 97 DAP sempre na parte da manhã. Antes do plantio foram coletados quatro tubérculos-semente de cada repetição, e aos 20, 27 e 34 DAP coletaram-se oito, cinco e cinco plantas por unidade experimental, respectivamente. A partir dos 41 DAP foram coletadas quatro plantas por unidade experimental. Em cada data de coleta foi definido o estádio de desenvolvimento das plantas de cada cultivar, sendo considerado como: Estádio I - crescimento vegetativo, da emergência até 34 DAP; Estádio II - tuberização, de 35 a 41 DAP; Estádio III - enchimento de tubérculos, de 42 a 90 DAP e Estádio IV - maturação, de 91 a 122 DAP.

As coletas foram realizadas seguindo alguns critérios, como: a) seleção de plantas que tinham de todos os lados plantas competitivas e b) seleção de plantas aparentemente bem nutridas e com ausência de sintomas de viroses, até quando possível.

Após serem removidas do campo, as plantas foram levadas ao Laboratório de Campo da Faculdade de Ciências Agronômicas - UNESP, campus de Botucatu e lavadas em água de torneira e água deionizada. Posteriormente, foram secadas ao ar por cerca de duas horas, para retirar o excesso de água, em seguida, separadas em tubérculossemente, raízes, hastes, folhas e tubérculos e avaliadas. Os tubérculos foram fatiados e, da mesma forma que as demais partes das plantas, foram acondicionados em sacos de papel e submetidos à secagem em estufa com circulação forçada de ar a $65{ }^{\circ} \mathrm{C}$ até atingir peso constante, o que durou em média 96 h. Após a secagem, foi determinada a MS das amostras em balança analítica, moídas em moinho tipo Wiley, com peneira de $1 \mathrm{~mm}$ e armazenadas, para posterior análise.

\subsection{Avaliações}

\subsubsection{Número médio de hastes por planta e comprimento da maior haste}

Estas avaliações foram realizadas em cada data de coleta de plantas em todas as plantas coletadas de cada unidade experimental, contando-se o número de hastes nas plantas coletadas e determinando-se o comprimento da maior haste a partir do ponto de inserção da haste no tubérculo-semente até o tufo apical. 


\subsubsection{Número médio de folhas na maior haste e por planta}

Foram determinados em todas as coletas, contando-se o número de folhas nas maiores hastes das plantas e, em todas as hastes de cada planta para a obtenção do número total de folhas por plantas.

\subsubsection{Número e massa fresca de tubérculos}

Em todas as coletas realizadas após o início da tuberização, os tubérculos, após lavagem, secagem ao ar e contagem, foram pesados para determinação da massa fresca média de tubérculos, da massa fresca de tubérculos por planta e da massa fresca de tubérculos por área.

\subsubsection{Acúmulo de matéria seca}

O acúmulo de MS foi determinado em cada órgão da planta (tubérculos-semente, raízes, hastes, folhas e tubérculos) e na planta toda pela soma do total acumulado em cada órgão da planta, em todas as coletas, de acordo com o descrito no item 5.4 .

\subsubsection{Taxa de acúmulo massa de matéria seca}

Os índices fisiológicos utilizados para avaliar possíveis diferenças entre os cultivares, foram à taxa de acúmulo de matéria seca da planta inteira e, a taxa de acúmulo de matéria seca nos tubérculos, obtidas pela manipulação das funções de ajuste.

A taxa de acúmulo de matéria seca da planta e dos tubérculos foi obtida por meio da derivada primeira das equações ajustadas de acúmulo de matéria seca da planta e dos tubérculos, determinando-se assim, os pontos de inflexão para cada equação. $\mathrm{O}$ ponto de inflexão representa o dia do ciclo de desenvolvimento da planta em que a taxa de acúmulo diário de matéria seca da planta e do tubérculo atingem o valor máximo. Do início do ciclo até o ponto de inflexão, a taxa de acúmulo diário é crescente e, após esse período, a taxa 
apresenta valores decrescentes. Já o ponto de máximo representa o dia do ciclo de desenvolvimento da planta em que o acúmulo de MS atinge o valor máximo. Após esse período, a planta começa a perder mais biomassa do que sua alocação.

\subsubsection{Taxa de crescimento relativo}

A taxa de crescimento relativo (TCR) é a medida mais apropriada para a avaliação do crescimento vegetal, que é dependente da quantidade de material que está sendo acumulado (MAGALHÃES, 1979). A TCR é definida como o aumento de matéria seca por unidade de matéria seca presente no início de determinado período, a qual foi obtida segundo a seguinte fórmula descrita por Radford (1967):

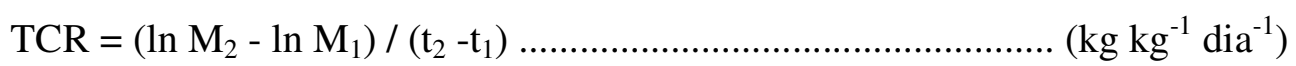

$\mathrm{M}_{1}$ e $\mathrm{M}_{2}$ é massa do órgão ou da planta referente aos tempos $\mathrm{t}_{1}$ e $\mathrm{t}_{2}$, respectivamente; ln é logaritmo neperiano.

\subsubsection{Distribuição de matéria seca}

Este parâmetro permite inferir outro processo fisiológico muito pouco estudado que é a translocação orgânica. Em muitos casos, a análise deste parâmetro facilita bastante a compreensão do comportamento vegetal em termos de produtividade (BENINCASA, 2003). A distribuição de matéria seca nos diferentes órgãos das plantas de batata foi calculada em porcentagem de matéria seca de cada órgão, em relação à matéria seca total obtida em cada amostragem ao longo do ciclo de desenvolvimento.

\subsubsection{Produtividade e classificação dos tubérculos produzidos}

Foi avaliada mediante a coleta dos tubérculos de 20 plantas por unidade experimental, 25 dias após a dessecação da parte aérea (122 DAP) de todas as cultivares. Os tubérculos colhidos foram lavados e classificados segundo o diâmetro em quatro classes: especial ou "graúda" (tubérculos com diâmetro maior que $45 \mathrm{~mm}$ ), primeira (tubérculos com diâmetro entre 33 e $45 \mathrm{~mm}$ ), segunda (tubérculos com diâmetro entre 23 e 33 
mm) e miúda (tubérculos com diâmetro inferior a $23 \mathrm{~mm}$ ). Após classificados os tubérculos foram pesados para determinação da produtividade de tubérculos por classes. A partir do somatório de todas as classes determinou-se a produtividade total de tubérculos e, a produtividade comercial de tubérculos foi obtida a partir do somatório das três primeiras classes (especial ou "graúda", primeira e segunda).

\subsubsection{Diagnose foliar}

Aos 30 dias após a emergência (DAE) (48 DAP) foi realizada a amostragem de folhas (terceira folha a partir do tufo apical) em cada unidade experimental de acordo com Lorenzi et al. (1997), para que fossem realizadas as determinações dos teores de $\mathrm{N}, \mathrm{P}, \mathrm{K}, \mathrm{Ca}, \mathrm{Mg}, \mathrm{S}, \mathrm{B}, \mathrm{Cu}, \mathrm{Fe}, \mathrm{Mn}$ e $\mathrm{Zn}$, segundo metodologia proposta por Malavolta et al. (1997).

\subsubsection{Teor e acúmulo de nutrientes}

As amostras utilizadas para determinação da MS, depois de moídas, foram submetidas à análise dos teores de $\mathrm{N}, \mathrm{P}, \mathrm{K}, \mathrm{Ca}, \mathrm{Mg}, \mathrm{S}, \mathrm{B}, \mathrm{Cu}, \mathrm{Fe}, \mathrm{Mn}$, e $\mathrm{Zn}$, segundo metodologia proposta por Malavolta et al. (1997). De posse desses resultados, foram estimadas as quantidades de nutrientes acumuladas em cada parte da planta, multiplicando-se o teor de cada nutriente pela MS do referido órgão. As quantidades de nutrientes acumuladas na planta inteira foram determinadas pela soma da quantidade de nutriente em cada órgão da planta.

\subsubsection{Porcentagem e taxa de absorção de nutrientes}

A porcentagem de absorção de nutrientes ao longo do ciclo das plantas foi obtida pela relação entre o máximo acúmulo na planta e a quantidade acumulada em cada época de coleta, por meio da manipulação das equações de ajuste das quantidades de nutrientes acumulados nas plantas. 
A taxa de acúmulo de nutrientes na planta inteira e nos tubérculos foi obtida por meio da derivada primeira da equação ajustada de acúmulo de nutrientes na planta inteira e nos tubérculos, determinando-se assim, os pontos de inflexão para cada equação, tal como descrito para a taxa de acúmulo de MS no item 5.5.5.

\subsubsection{Porcentagem de matéria seca e exportação de nutrientes}

Uma amostra de tubérculos (proporcional entre todas as classes) de cada parcela, obtidos na última avaliação (colheita), foi coletada aleatoriamente pesados (peso fresco), fatiados e secos em estufa com circulação forçada de ar a $65{ }^{\circ} \mathrm{C}$ até peso constante, obtendo-se a MS. Em seguida, determinou-se os teores de N, P, K, Ca, Mg, S, B, Cu, Fe, Mn, e Zn, segundo Malavolta et al. (1997). A exportação de nutrientes foi estimada mediante a multiplicação dos teores de cada nutriente pela MS, sendo os dados expressos em quantidade de nutrientes exportada por área e por tonelada de tubérculos produzidos.

\subsection{Análise estatística}

Os dados obtidos foram submetidos à análise de variância. As médias dos cultivares foram comparadas pelo teste de Tukey a $5 \%$ de probabilidade. Os efeitos das épocas de coletas de plantas para as variáveis de crescimento, acúmulo de matéria seca e acúmulo de nutrientes foram submetidos a análise de regressão, com auxílio do "software" SigmaPlot 10.0. As equações foram obtidas para descrever a variação, no tempo, das variáveis avaliadas. 


\section{RESULTADOS E DISCUSSÃO}

\subsection{Crescimento e acúmulo de matéria seca}

As cultivares de batata diferiram quanto ao número de hastes por planta em todas as épocas de avaliação (Figura 2A). Durante todo o ciclo de cultivo os maiores números de hastes por planta foram observados nas cultivares Asterix e Ágata. As demais cultivares obtiveram número de hastes por planta inferior a 3,3, sendo que, os menores valores apresentados pelas cultivares Mondial, Markies e Atlantic, ocorreram devido ao menor peso dos tubérculos-semente que foram de $31 \mathrm{~g}$, 28g e 36g, respectivamente. Feltran (2002) estudando o comportamento agronômico de cultivares de batata durante a safra das "águas", observou número médio de hastes por planta na cultivar Mondial de 6,3, ou seja, superior ao observado no presente estudo. Porém, o mesmo autor obteve número de hastes por planta de 2,5 e 2,3 para as cultivares Asterix e Ágata, os quais foram inferiores aos observados neste estudo. Estas diferenças entre o número médio de hastes por planta estão relacionadas com o tamanho (SOUZA, 2003) e idade fisiológica dos tubérculos-semente utilizados no plantio, uma vez que, a idade fisiológica dos tubérculos-semente determina o potencial de brotação, influenciando assim o número de hastes por planta (CALDIZ, 1994). Morena et al. (1994) também relataram que o número médio de hastes por planta é uma variável que é bastante afetada pelas características de cada cultivar. 
Quanto ao comprimento da maior haste, no período da emergência até os 48 DAP a cultivar Asterix apresentou maior porte, no entanto, a partir dos 62 DAP até o final do ciclo a cultivar Mondial sobressaiu em relação às demais, apresentando comprimento médio de $79 \mathrm{~cm}$ na maior haste, na fase final do ciclo (Figura 2B). A cultivar Asterix apresentou comprimento intermediário da maior haste no final do ciclo. Já as cultivares Ágata, Asterix e Atlantic apresentaram comprimento da maior haste semelhante durante todo o ciclo de desenvolvimento.
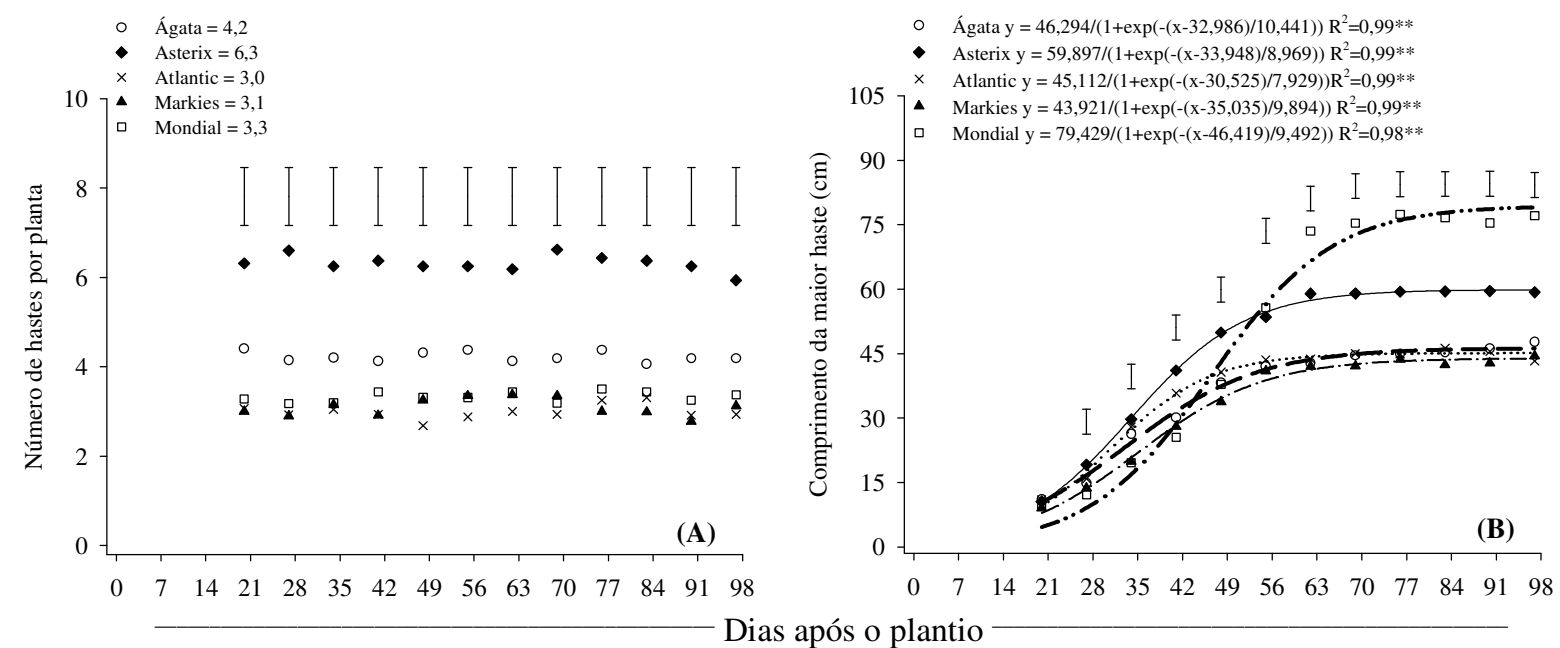

Figura 2. Número de hastes por planta (A) e comprimento da maior haste (B) de cultivares de batata ao longo do ciclo. ** significativo a $1 \%$ de probabilidade pelo teste $\mathrm{F}$. Barras verticais indicam o valor de DMS pelo teste Tukey a $5 \%$ de probabilidade.

O maior número de folhas na maior haste foi observado na cultivar Mondial, principalmente no período de 48 a 90 DAP, enquanto que nas demais cultivares o número de folhas na maior haste foi semelhante (Figura 3A).

Quanto ao número de folhas por planta, no início do ciclo de desenvolvimento, a cultivar Mondial, apresentou crescimento lento com a formação de poucas folhas, porém, com o decorrer do desenvolvimento das plantas, houve maior crescimento e emissão de folhas por essa cultivar, além de senescência e queda de folhas na cultivar Asterix a partir dos 69 DAP, o que refletiu em ausência de diferenças entre a quantidade de folhas em ambas as cultivares no final do ciclo de desenvolvimento (Figura 3B). 
No entanto, de maneira geral, no período entre 69 e 97 DAP, ocorreu a redução do número de folhas em todas as cultivares estudadas, em decorrência da senescência e queda de folhas (Figura 3B). A cultivar Mondial apresentou menor número de hastes por planta que Asterix (Figura 2A), porém, sua produção de folhas no final do ciclo de desenvolvimento foi semelhante ao da cultivar Asterix (Figura 3B), devido, principalmente, à presença de hastes maiores (Figura 2B) e com maior quantidade de folhas (Figura 3A).

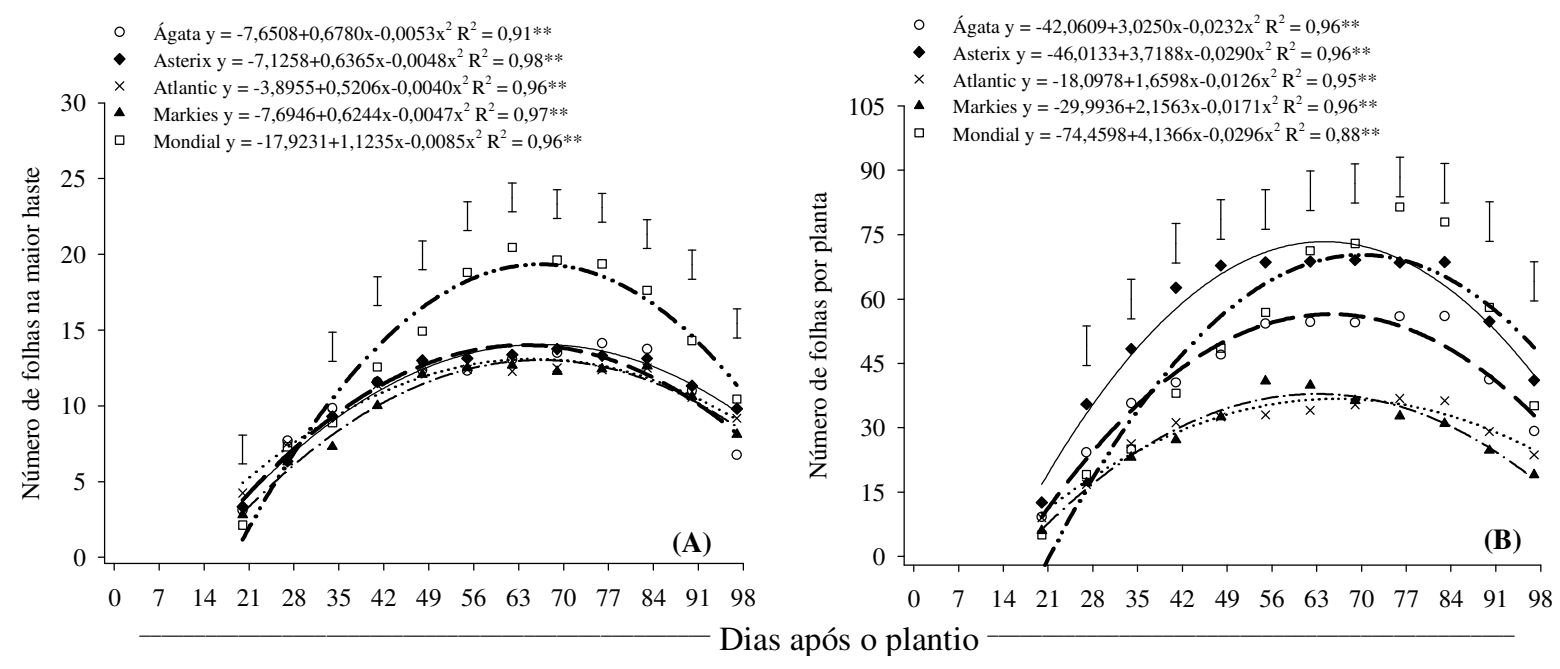

Figura 3. Número de folhas na maior haste (A) e número de folhas por planta (B) de cultivares de batata ao longo do ciclo. ** significativo a $1 \%$ de probabilidade pelo teste $\mathrm{F}$. Barras verticais indicam o valor de DMS pelo teste Tukey a 5\% de probabilidade.

Embora as cultivares, Ágata, Markies e Atlantic não tenham diferido quanto ao comprimento da maior haste (Figura 2B) e ao número de folhas na maior haste (Figura 3A), a cultivar Ágata apresentou maior número de folhas por planta que Markies e Atlantic (Figura 3B), pelo fato da cultivar Ágata ter apresentado maior número de hastes por planta que as cultivares Markies e Atlantic (Figura 2A).

Os maiores números de tubérculos foram observados nas cultivares Ágata, Asterix e Mondial, enquanto, Atlantic e Markies apresentaram as menores quantidades de tubérculos por planta (Figura 4A). Aos 97 DAP os tubérculos maiores foram observados nas cultivares Mondial, Markies, Asterix, Atlantic e Ágata, respectivamente (Figura 4B). Embora, a cultivar Ágata tenha apresentado maior número de tubérculos por planta (Figura 4A), os tubérculos foram menores, ou seja, apresentaram menor peso médio (Figura 4B), o 
que refletiu em produção de tubérculos por planta e por área semelhante ao das cultivares Asterix e Mondial no final do ciclo (Figura 4C e 4D). Por apresentar maior número de tubérculos por planta e maior peso médio de tubérculos, as cultivares Asterix e Mondial apresentaram as maiores produções de tubérculos no final do ciclo de desenvolvimento, as quais não diferiram de Ágata. A cultivar Markies teve como característica apresentar número de tubérculos por planta semelhante a cultivar Atlantic, porém, de maior massa média, o que refletiu em produções por planta e por área maiores que as obtidas na cultivar Atlantic.
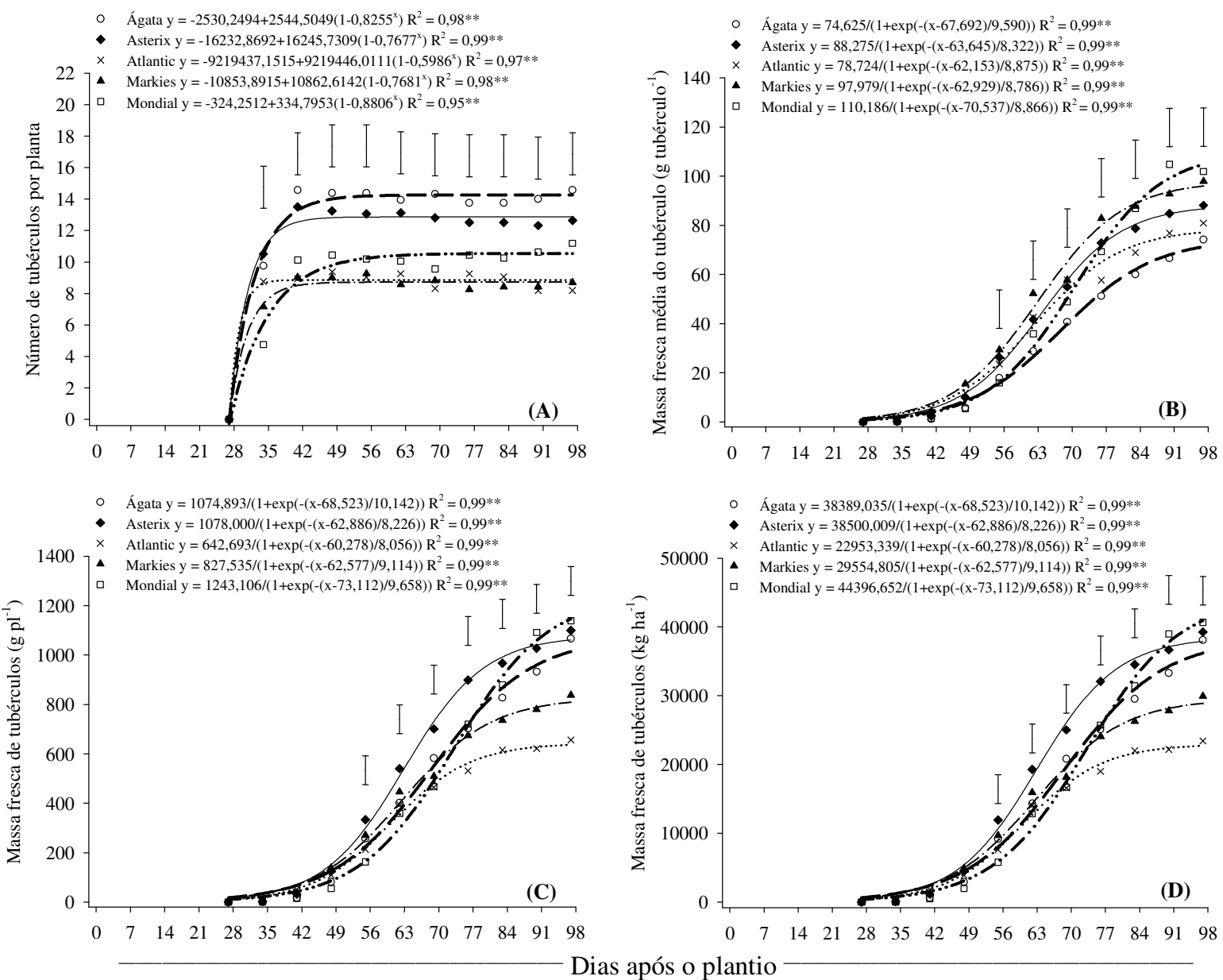

Figura 4. Número de tubérculos por planta (A), massa fresca média de tubérculos (B), massa fresca de tubérculos por planta (C) e massa fresca de tubérculos por área (D) de cultivares de batata ao longo do ciclo. ${ }^{* *}$ significativo a $1 \%$ de probabilidade pelo teste $\mathrm{F}$. Barras verticais indicam o valor de DMS pelo teste Tukey a $5 \%$ de probabilidade. 
Nas fases iniciais do ciclo, as plantas das cultivares de batata utilizaram as reservas contidas nos tubérculos-semente, o que pode ser comprovado pelas reduções das quantidades de MS contidas nos tubérculos-semente no decorrer do ciclo da cultura (Figura 5A). Diferenças entre as quantidades de MS dos tubérculos-semente foram observadas apenas nas amostragens realizadas antes do plantio e na primeira avaliação após a emergência, nas quais, as cultivares Asterix e Atlantic apresentaram as maiores quantidades de MS. Os tubérculos-semente representaram mais de 50\% de toda MS presente nas plantas das cultivares Ágata, Markies e Mondial, até os 27 DAP, enquanto que para as cultivares Atlantic e Asterix esse valor foi de 47,6 e 31,1\%, respectivamente (Tabela 3). Esses resultados indicam que as cultivares Asterix e Atlantic tiveram desenvolvimento inicial mais rápido, devido a maior quantidade de reservas nos tubérculos-semente (Figura 5A).

Os acúmulos de MS nas raízes ocorreram de forma crescente até próximo aos 48 DAP para as cultivares Ágata, Atlantic e Asterix, atingindo as quantidades máximas acumuladas de 13,2, 22,2 e 26,3 $\mathrm{kg} \mathrm{ha}^{-1}$ aos 48 DAP, respectivamente (Figura 5B). Já a cultivar Markies, apresentou maior acúmulo de MS nas raízes aos 55 DAP, com valores de $17,9 \mathrm{~kg} \mathrm{ha}^{-1}$. A cultivar Mondial foi a mais tardia em acumular MS nas raízes, atingindo o ponto de máximo depois de $55 \mathrm{DAP}$, com quantidades da ordem de 17,0 $\mathrm{kg} \mathrm{ha}^{-1}$. De maneira geral, com exceção da cultivar Mondial, a partir dos 55 DAP houve redução na quantidade de MS acumulada nas raízes de todas as cultivares até o final do ciclo, provavelmente devido a morte de raízes. Os maiores acúmulos de MS nas raízes foram observados nas cultivares Asterix (26,3 kg ha $\left.{ }^{-1}\right)$ e Atlantic (22,2 $\left.\mathrm{kg} \mathrm{ha}^{-1}\right)$, enquanto, as menores quantidades de MS acumuladas no referido órgão, foram observadas na cultivar Ágata $\left(13,2 \mathrm{~kg} \mathrm{ha}^{-1}\right)$. Yorinori (2003) observou em duas safras que os acúmulos máximos de MS nas raízes da cultivar Atlantic ocorreram aos 48 DAP na safra das secas, sendo de $28,8 \mathrm{~kg} \mathrm{ha}^{-1}$ e aos 72 DAP na safra das águas sendo de $26,7 \mathrm{~kg} \mathrm{ha}^{-1}$, resultados esses, superiores aos aqui encontrados, possivelmente, devido a utilização de maiores populações de plantas (41.667 plantas ha $^{-1}$ ).

Entre os órgãos das plantas, as raízes chegaram a representar $8,2 \%$, $6,2 \%, 5,5 \%, 5,2 \%$ e 3,7\% de toda MS acumulada até aos 27 DAP e, à medida que ocorreu o crescimento intenso das demais partes das plantas e a redução do crescimento das raízes a partir dos 55 DAP, a contribuição da MS do sistema radicular na MS total da planta no final do ciclo (97 DAP) ficou em torno de $0,2 \%$ em todas as cultivares (Tabela 3 ). 

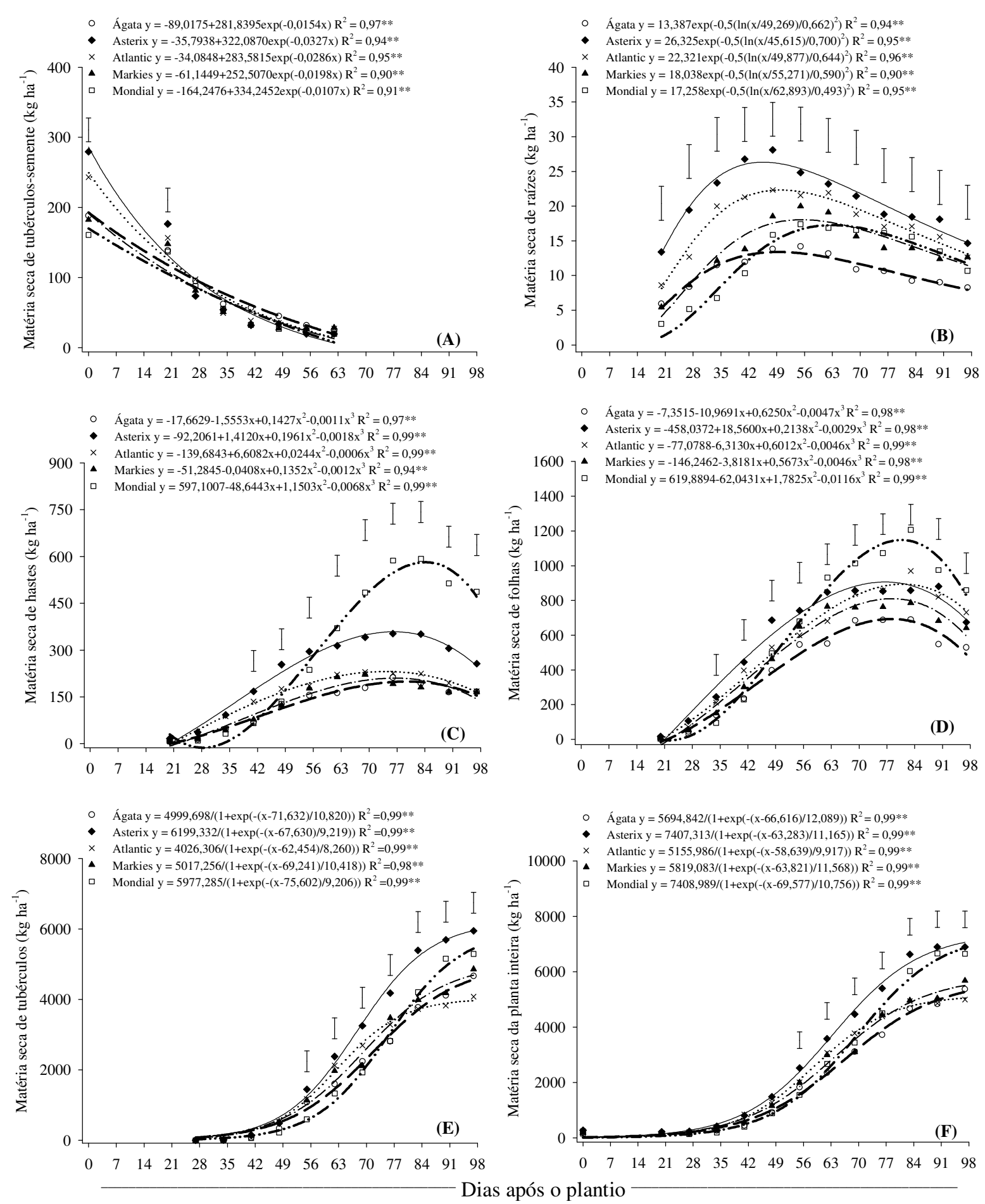

Figura 5. Quantidade de MS nos tubérculos-semente (A), raízes (B), hastes (C), folhas (D), tubérculos $(\mathrm{E})$ e na planta inteira $(\mathrm{F})$ de cultivares de batata ao longo do ciclo. $* *$ significativo a $1 \%$ de probabilidade pelo teste F. Barras verticais indicam o valor de DMS pelo teste Tukey a $5 \%$ de probabilidade. 
Tabela 3. Porcentagem de matéria seca em cada órgão das plantas, em relação à matéria seca total das plantas de cultivares de batata ao longo do ciclo.

\begin{tabular}{|c|c|c|c|c|c|c|c|c|c|c|c|c|c|}
\hline \multirow{2}{*}{ Partes das plantas } & \multicolumn{13}{|c|}{ Dias após o plantio } \\
\hline & 0 & 20 & 27 & 34 & 41 & 48 & 55 & 62 & 69 & 76 & 83 & 90 & 97 \\
\hline & \multicolumn{13}{|c|}{ Ágata } \\
\hline Tubérculos-semente & 100 & 87,7 & 58,3 & 23,4 & 12,6 & 4,9 & 1,7 & 1,1 & - & - & - & - & - \\
\hline Raíze & - & 3,8 & 5,2 & 4,3 & 2,7 & 1,5 & 0,8 & 0,6 & 0,3 & 0,3 & 0,2 & 0,2 & 0,2 \\
\hline & - & 5,0 & 8,6 & 17,4 & 15,3 & 13,7 & 8,5 & 6,9 & 5,7 & 5,7 & 4,2 & 3,4 & 3,1 \\
\hline & - & 3,5 & 27,9 & 52,7 & 52,5 & 43,2 & 29,9 & 23,4 & 22,1 & 18,5 & 14,8 & 11,3 & 9,9 \\
\hline \multirow[t]{2}{*}{ Tubérculos } & - &.- & - & 2,2 & 16,9 & 36,7 & 59,1 & 68,0 & 71,9 & 75,5 & 80,8 & 85,1 & 86,8 \\
\hline & \multicolumn{13}{|c|}{ Asterix } \\
\hline uhérculos_semente & 100 & 79,1 & 31,1 & 12,8 & 4,0 & 2,3 & 0,8 & 0,5 & - & - & - & - & - \\
\hline & - & 6,0 & 8,2 & 5,5 & 3,3 & 1,9 & 1,0 & 0,6 & 0,5 & 0,3 & 0,3 & 0,3 & 0,2 \\
\hline & - & 7,4 & 15,6 & 21,8 & 20,6 & 17,0 & 11,7 & 8,8 & 7,6 & 6,5 & 5,3 & 4,4 & 3,7 \\
\hline & - & 7,5 & 45,1 & 57,6 & 54,9 & 46,1 & 29,3 & 23,7 & 19,2 & 15,8 & 13,0 & 12,8 & 9,8 \\
\hline \multirow[t]{2}{*}{ ubérculos } & - & - & - & 2,3 & 17,2 & 32,7 & 57,2 & 66,4 & 72,7 & 77,4 & 81,4 & 82,5 & 86,3 \\
\hline & \multicolumn{13}{|c|}{ Atlantic } \\
\hline & 100 & 85,0 & 47,6 & 12,9 & 4,6 & 2,7 & 1,4 & 0,9 & - & - & - & & - \\
\hline & - & 4,7 & 6,2 & 5,2 & 2,5 & 1,7 & 1,1 & 0,7 & 0,5 & 0,4 & 0,3 & 0,3 & 0,3 \\
\hline & - & 4,9 & 11,8 & 22,9 & 16,0 & 13,7 & 9,3 & 7,2 & 6,1 & 5,1 & 4,5 & 4,0 & 3,4 \\
\hline & - & 5,4 & 34,4 & 55,5 & 47,2 & 41,3 & 29,8 & 22,1 & 22,1 & 19,6 & 19,6 & 16,9 & 14,6 \\
\hline \multirow[t]{2}{*}{ Tubérculos } & - & - & - & 3,5 & 29,7 & 40,6 & 58,4 & 69,1 & 71,3 & 74,9 & 75,6 & 78,8 & 81,7 \\
\hline & \multicolumn{13}{|c|}{ Markies } \\
\hline & 100 & 88,3 & 51,7 & 19,1 & 5,9 & 2,4 & 1,3 & 1,0 & - & - & - & & - \\
\hline & - & 3,3 & 5,5 & 4,5 & 2,4 & 1,6 & 1,0 & 0,6 & 0,5 & 0,3 & 0,3 & 0,2 & 0,2 \\
\hline & - & 4,5 & 9,9 & 16,1 & 13,6 & 10,6 & 8,8 & 7,1 & 7,1 & 4,3 & 3,6 & 3,4 & 2,9 \\
\hline & - & 3,9 & 32,9 & 56,1 & 53,2 & 40,0 & 32,4 & 25,6 & 24,5 & 17,2 & 15,8 & 13,5 & 11,3 \\
\hline \multirow[t]{2}{*}{ Tubérculos } & - & - & - & 4,2 & 24,9 & 45,4 & 56,5 & 65,7 & 67,9 & 78,2 & 30,3 & 82,9 & 85, \\
\hline & \multicolumn{13}{|c|}{ Mondial } \\
\hline & 100 & 90,0 & 63,6 & 28,7 & 8,1 & 3,0 & 1,6 & 0,7 & - & - & - & - & - \\
\hline & - & 2,0 & 3,7 & 3,5 & 2,6 & 1,8 & 1,1 & 0,6 & 0,5 & 0,4 & 0,3 & 0,2 & 0,2 \\
\hline & - & 5,0 & 7,4 & 16,9 & 16,2 & 15,1 & 15,2 & 13,9 & 14,1 & 13,1 & 9,8 & 7,7 & 7,3 \\
\hline & - & 3,0 & 25,3 & 49,5 & 56,9 & 55,5 & 43,7 & 34,9 & 29,4 & 23,8 & 20,0 & 14,7 & 12,9 \\
\hline Tubérculos & - & - & - & 1,4 & 16,2 & 24,6 & 38,4 & 49,9 & 56,0 & 62,7 & 69,9 & 77,4 & 79,6 \\
\hline
\end{tabular}

Nas hastes, os acúmulos de MS foram crescentes até próximo aos 76 DAP nas cultivares Asterix, Atlantic, Markies e Ágata, com valores ao redor de 358,8, 230,9, 210,1 e 199,1 kg ha-1 , respectivamente (Figura 5C). Já na cultivar Mondial o acúmulo de MS nas hastes foi maior e crescente até próximo aos 83 DAP, atingindo a quantidade máxima estimada de $581,5 \mathrm{~kg} \mathrm{ha}^{-1}$. O acúmulo máximo de MS nas hastes obtido por Yorinori (2003) para a cultivar Atlantic, na safra da seca e das águas, ocorreu aos 47 DAP e 83 DAP, sendo $602,9 \mathrm{~kg} \mathrm{ha}^{-1}$ e $513,7 \mathrm{~kg} \mathrm{ha}^{-1}$, respectivamente, ou seja, maiores que os encontrados para a 
mesma cultivar no presente estudo. As cultivares que mais acumularam MS nas hastes foram Asterix e Mondial, reflexo da presença do maior número de hastes na cultivar Asterix e hastes maiores na cultivar Mondial (Figuras 2A e 2B).

De toda MS acumulada nas plantas até aos 34 DAP, as hastes tiveram participação com aproximadamente 16 a 17\% nas cultivares Ágata, Markies e Mondial, enquanto que nas cultivares Asterix e Atlantic, a MS proveniente das hastes representou em torno de $22 \%$ de toda a MS acumulada pelas plantas até aquele momento (Tabela 3). Nos períodos seguintes, a contribuição da MS das hastes para a MS total diminuiu, chegando as hastes a representar de 2,9 a 7,3\% da MS total na última avaliação (Tabela 3). Esse fato está relacionado com o crescimento e aumento contínuo da MS dos tubérculos a partir dos 34 DAP até o final do ciclo (Figura 5E).

As folhas acumularam MS continuamente até próximo ao final do ciclo, atingindo aos 76, 78, 78, 80 e 80 DAP, as quantidades máximas estimadas de 906,2, 692,7, 810,0, 893,7 e 1.147,4 $\mathrm{kg} \mathrm{ha}^{-1}$, respectivamente, para as cultivares Asterix, Ágata, Markies, Atlantic e Mondial (Figura 5D). A cultivar Asterix foi a mais precoce em alcançar a produção máxima de MS das folhas, atingindo o ponto de máximo acúmulo de MS nas folhas de $906,2 \mathrm{~kg} \mathrm{ha}^{-1}$ aos 76 DAP, enquanto as cultivares Mondial e Atlantic atingiram o máximo acúmulo de $1.147,4$ e $893,7 \mathrm{~kg} \mathrm{ha}^{-1}$ aos 80 DAP. O maior acúmulo de MS nas folhas foi observado na cultivar Mondial aos 83 DAP, enquanto que as menores quantidades de MS foram observadas nas folhas da cultivar Ágata. Em todas as cultivares estudadas a queda abundante de folhas no período de 80 a 97 DAP (Figura 3B) proporcionou redução gradativa do acúmulo de MS nas folhas (Figura 5D). Yorinori (2003) observaram acúmulos máximos de MS nas folhas da cultivar Atlantic durante a safra das águas foi de 944,6 $\mathrm{kg} \mathrm{ha}^{-1}$ (79 DAP), enquanto que na safra das secas os acúmulos foram menores e em torno de $645,83 \mathrm{~kg} \mathrm{ha}^{-1}$ (41 DAP). Assim, observa-se que o maior acúmulo de MS nas folhas de todas as cultivares ocorreu praticamente na mesma época observada por Yorinori (2003) durante a safra das águas, ou seja, próximo dos 78 DAP (Figura 5D).

As folhas participaram com mais de $52 \%$ de toda MS acumulada nas plantas das cultivares Ágata, Asterix, Atlantic e Markies até aos 34 DAP, enquanto que na cultivar Mondial esse valor foi da ordem de 49,5\% (Tabela 3). Com o crescimento e desenvolvimento dos tubérculos e devido à perda de folhas, houve alterações na distribuição 
da MS entre os órgãos das plantas, de modo que no final do ciclo a MS das folhas representou de $9,8 \%$ a $14,6 \%$ da MS total das cultivares estudadas (Tabela 3 ).

A MS acumulada pelos tubérculos, foi pequena em todas as cultivares do início de tuberização até aos 48 (Figura 5E) e, a partir dos 55 DAP, ocorreu o crescimento acelerado na MS dos tubérculos até em torno dos 69 DAP, quando as cultivares Atlantic, Asterix, Markies, Ágata e Mondial atingiram as taxas máximas de acúmulos de MS nos tubérculos que foram de 121,8, 168,1, 120,4, 115,5 e 162,3 $\mathrm{kg} \mathrm{ha}^{-1} \mathrm{dia}^{-1}$, aos 62, 67, 69, $72 \mathrm{e}$ 75 DAP, respectivamente (Figura 6A e Tabela 4).
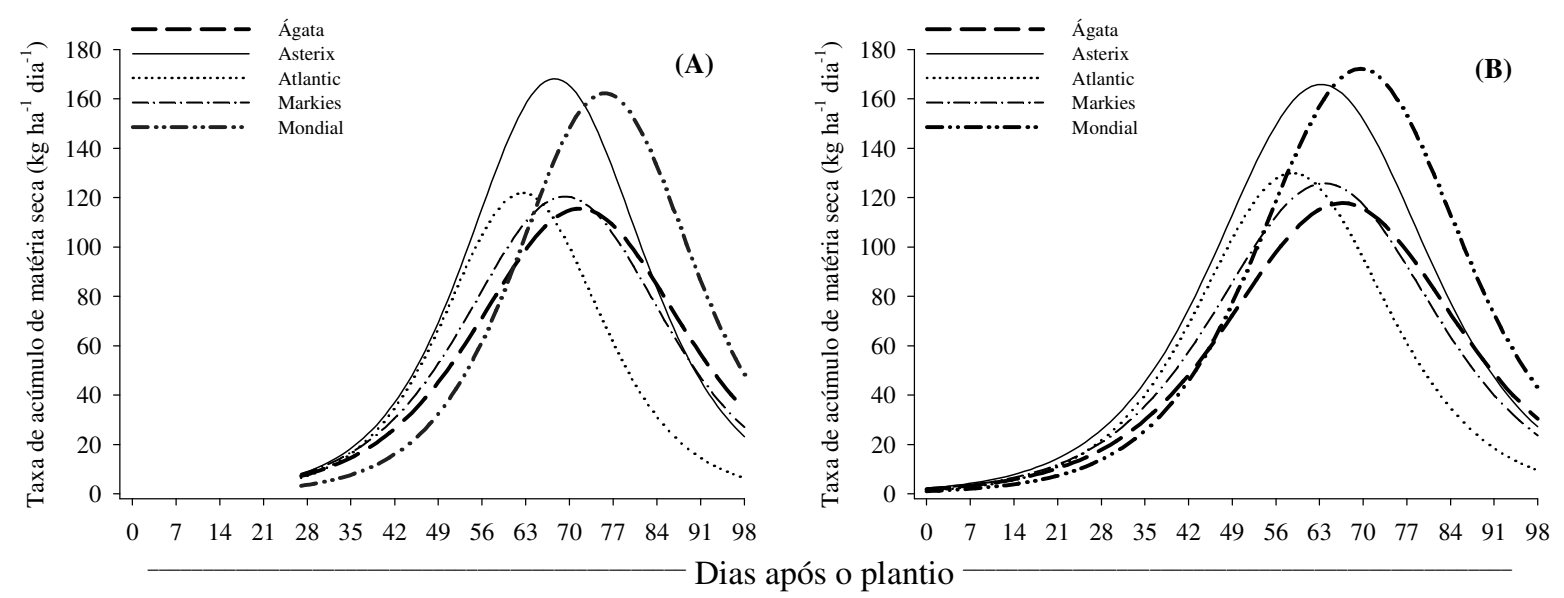

Figura 6. Taxa de acúmulo de matéria seca nos tubérculos (A) e na planta inteira (B) de cultivares de batata ao longo do ciclo.

Tabela 4. Quantidade máxima de MS acumulada, taxa diária máxima de acúmulo e época de maior taxa de acúmulo de MS nos tubérculos e nas plantas de cultivares de batata.

\begin{tabular}{lcccccc}
\hline Cultivares & $\begin{array}{c}\text { Acúmulo } \\
\text { máximo no } \\
\text { tubérculo }\end{array}$ & $\begin{array}{c}\text { Taxa } \\
\text { máxima de } \\
\text { acúmulo no } \\
\text { tubérculo }\end{array}$ & $\begin{array}{c}\text { Época de } \\
\text { maior taxa de } \\
\text { acúmulo no } \\
\text { tubérculo }\end{array}$ & $\begin{array}{c}\text { Acúmulo } \\
\text { máximo na } \\
\text { planta }\end{array}$ & $\begin{array}{c}\text { Taxa } \\
\text { máxima de } \\
\text { acúmulo na } \\
\text { planta }\end{array}$ & $\begin{array}{c}\text { Época de } \\
\text { maior taxa } \\
\text { de acúmulo } \\
\text { na planta }\end{array}$ \\
\hline Ágata & $\mathrm{kg} \mathrm{ha}^{-1}$ & $\mathrm{~kg} \mathrm{ha}^{-1}$ dia $^{-1}$ & DAP & $\mathrm{kg} \mathrm{ha}^{-1}$ & $\mathrm{~kg} \mathrm{ha}^{-1} \mathrm{dia}^{-1}$ & $\mathrm{DAP}$ \\
Asterix & 4.562 & 115,51 & 72 & 5.268 & 117,76 & 69 \\
Atlantic & 5.953 & 168,10 & 67 & 7.062 & 165,79 & 64 \\
Markies & 3.966 & 121,85 & 62 & 5.050 & 129,96 & 59 \\
Mondial & 4.691 & 120,36 & 69 & 5.506 & 125,75 & 64 \\
\hline
\end{tabular}


A cultivar Asterix apresentou crescimento intenso dos tubérculos a partir dos 55 DAP com acúmulo de MS superior ao das demais cultivares, com exceção da Mondial a partir de 90 DAP (Figura 5E), o que ocorreu em função das altas taxas de acúmulo de MS nos tubérculos da Asterix, observadas desde o início da tuberização até aos 76 DAP (Figura 6A). Embora, não tenham ocorrido diferenças significativas, a cultivar Atlantic apresentou o menor acúmulo de MS nos tubérculos durante o período de 90 a 97 DAP. No entanto, observa-se que houve acúmulo de MS nos tubérculos do início da tuberização até o final do ciclo, sendo que as quantidades máximas de MS acumuladas ocorreram aos 97 DAP, atingindo 4.562, 5.953, 3.966, 4.691 e $5.444 \mathrm{~kg} \mathrm{ha}^{-1}$, respectivamente, nas cultivares Ágata, Asterix, Atlantic, Markies e Mondial (Figura 5E).

Na safra das águas, Yorinori (2003) observou o acúmulo máximo de MS nos tubérculos da cultivar Atlantic aos 106 DAP, com acúmulo de $8.274 \mathrm{~kg} \mathrm{ha}^{-1}$, enquanto na safra da seca, o máximo acúmulo ocorreu aos 82 DAP, com acúmulo de $5.734 \mathrm{~kg} \mathrm{ha}^{-1}$. Dessa forma, observa-se que os acúmulos de MS nos tubérculos das cultivares estudadas, foram praticamente todos inferiores aos obtidos por Yorinori (2003).

Os tubérculos foram os drenos principais das plantas a partir dos 48 DAP até a última coleta de plantas aos 97 DAP, chegando a representar no final do ciclo entre $85,6 \%$ e $86,8 \%$ da MS total acumulada pelas plantas das cultivares Markies, Asterix e Ágata e, entre 79,6\% e 81,7\% nas cultivares Mondial e Atlantic (Tabela 3). A parte aérea, representada pelas hastes e folhas, teve maior participação na MS total das plantas até cerca de 34 DAP, quando correspondeu a 70,1\%,79,4\%,78,4\%,72,2\% e 66,4\% da MS total acumulada nas plantas das cultivares Ágata, Asterix, Atlantic, Markies e Mondial, respectivamente. Porém, com o início da tuberização, alterou-se a força de dreno das plantas, aumentando assim a translocação de fotoassimilados das folhas para os tubérculos, de modo que, com exceção da cultivar Mondial, o acúmulo de MS nos tubérculos até aos 55 DAP representava mais de $56,1 \%$ do total das plantas, contra menos de 41,2\% da parte aérea, nas cultivares Ágata, Asterix, Atlantic e Markies, ou seja, mais da metade da MS total da planta já era composta por tubérculos (Tabela 3). Esses dados confirmam os relatos de Westermann (1993) de que os tubérculos da batateira são os principais drenos de carboidratos e nutrientes inorgânicos móveis durante o período de enchimento dos mesmos. 
Com base nos acúmulos de MS das plantas inteiras, observa-se que as plantas das cultivares tiveram crescimento lento e não diferiram entre si até os $48 \mathrm{DAP}$, com acúmulo de MS intensificando-se a partir dos 55 DAP até o final do ciclo (Figura 5F). A cultivar Asterix apresentou crescimento intenso e maior produção de MS entre 55 e 83 DAP (Figura 5F), devido ao fato dessa cultivar ter apresentado as maiores taxas de acúmulo de MS desde a emergência até aos 64 DAP (Figura 6B e Tabela 4). Porém, na fase final do ciclo a cultivar Mondial passou a apresentar taxa de acúmulo de MS superior ao da cultivar Asterix (Figura 6B), o que proporcionou crescimento rápido dessa cultivar, nesse período, e acúmulo de MS semelhante ao observado em Asterix (Figura 5F). As cultivares Markies, Ágata e Atlantic apresentaram acúmulo de MS semelhante e inferior ao obtido nas cultivares Asterix e Mondial dos 83 DAP até o final do ciclo (Figura 5F), o que é resultado das taxas semelhantes de acúmulo de MS entre essas cultivares, porém, inferiores àquelas obtidas nas cultivares Mondial e Asterix (Figura 6B e Tabela 4). De maneira geral, houve acúmulo de MS nas plantas, ao longo de todo o ciclo, sendo que a produção total máxima estimada de MS ocorreu aos 97 DAP, atingindo 5.268, 7.062, 5.050, 5.506 e $6.872 \mathrm{~kg} \mathrm{ha}^{-1}$, respectivamente, nas cultivares Ágata, Asterix, Atlantic, Markies e Mondial (Figura 5F e Tabela 4).

Yorinori (2003), estudando a curva de crescimento e de acúmulo de nutrientes pela batateira, cultivar Atlantic em duas safras, com uma população de 41.667 plantas por ha ${ }^{-1}$, observou as maiores taxas de acúmulo de MS durante a safra das águas no período de 62 a 69 DAP, ou seja, em época semelhante à observada para a maioria das cultivares estudadas no presente experimento (Figura 6B e Tabela 4). Porém, os incrementos de MS obtidos por esse autor, na safra das águas, foram superiores ao observado para todas as cultivares estudadas, com valores de até $246 \mathrm{~kg} \mathrm{ha}^{-1} \mathrm{dia}^{-1}$. Já na safra das secas, embora, as maiores taxas de acúmulo de MS (242 $\mathrm{kg} \mathrm{ha}^{-1} \mathrm{dia}^{-1}$ ) obtidas por Yorinori (2003) tenham sido superiores ao das cultivares estudadas no presente experimento, os maiores incrementos de MS ocorreram no período de 48 a 55 DAP, ou seja, antes do observado para todas as cultivares neste estudo (Figura 6B e Tabela 4). Esse autor também relata que os acúmulos máximos totais de MS nas plantas foram de $9.161 \mathrm{~kg} \mathrm{ha}^{-1}$ aos 103 DAP durante a safra das águas, sendo estes superiores ao de todas as cultivares estudadas (Figura 5F e Tabela 4). No entanto, na safra das secas o acúmulo máximo de MS obtido por Yorinori (2003) foi de 6.226 
$\mathrm{kg} \mathrm{ha}^{-1}$ aos 77 DAP e inferiores aos observados nas cultivares Asterix (7.062 $\left.\mathrm{kg} \mathrm{ha}^{-1}\right) \mathrm{e}$ Mondial (6.872 $\mathrm{kg} \mathrm{ha}^{-1}$ ) (Figura 5F e Tabela 4).

A taxa de crescimento relativo (TCR), que representa a quantidade de material vegetal produzido por determinada quantidade de material existente, durante um intervalo de tempo prefixado (MAGALHÃES, 1979), foi crescente até próximo aos 41 DAP, atingindo o ponto de máximo de 0,0966, 0,0959, 0,0969, 0,1095 e 0,1093 $\mathrm{kg} \mathrm{kg}^{-1} \mathrm{dia}^{-1}$, aos 42, 40, 38, 41 e 44 DAP, respectivamente para as cultivares Ágata, Asterix, Atlantic, Markies e Mondial (Figura 7).

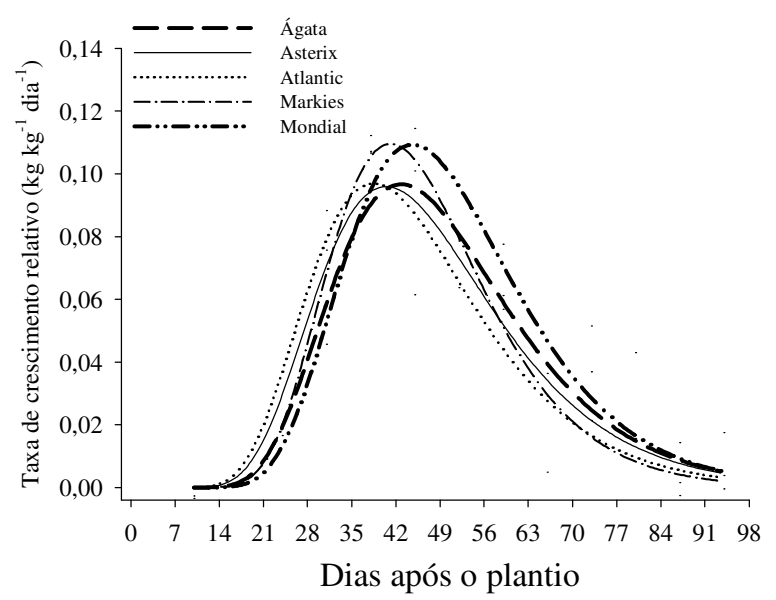

Figura 7. Taxa de crescimento relativo de plantas de cultivares de batata ao longo do ciclo.

A TCR de uma planta depende simultaneamente da eficiência assimilatória de suas folhas e da folhagem, ou seja, do número de folhas por planta e do tamanho das folhas da própria planta (OLIVEIRA; GOMIDE, (1986) citado por GUIMARÃES, 1994). Assim, o aumento na TCR até próximo aos 41 DAP é reflexo do aumento intenso da superfície fotossintetizante, ou seja, do crescimento das folhas (Figura 3), bem como, da maior proporção entre superfície fotossinteticamente ativa (folhas) e quantidade de material não assimilatório, uma vez que, aos 41 DAP a MS das folhas representava mais de $50 \%$ da MS total das plantas da maioria das cultivares estudadas (Tabela 3).

A partir dos 48 DAP, quando intensificou-se o crescimento dos tubérculos (Figura 5E), a contribuição percentual da MS das folhas em relação a MS total das plantas (Tabela 3) e a TCR foram sempre decrescente em todas as cultivares estudadas, o que 
em parte, é resultado do aumento gradativo de tecidos não fotossintetizantes (LOPES et al., 1986; REYES-CUESTA et al.,1995), ou seja, principalmente os tubérculos. Aguiar Neto et al. (2000) e Barcelos et al. (2007) também observaram declínio da TCR conforme as plantas de batata foram atingindo a maturidade. Milthorpe e Moorey (1974) e Rodrigues et al. (1993), trabalhando com diferentes plantas, relatam que esse declínio na TCR durante a fase final do ciclo também está relacionado com a queda ou morte de folhas, fato este, que também foi observado neste estudo (Figura 3B).

\subsection{Produtividade de tubérculos}

Houve diferença entre as cultivares estudadas quanto à produtividade de tubérculos, bem como, quanto à distribuição da produtividade por classes (Tabela 5). As maiores produtividades totais de tubérculos foram obtidas para as cultivares Mondial (40.908 $\mathrm{kg} \mathrm{ha}^{-1}$ ) e Asterix (40.002 $\left.\mathrm{kg} \mathrm{ha}^{-1}\right)$, seguidas da cultivar Ágata $\left(37.268 \mathrm{~kg} \mathrm{ha}^{-1}\right)$, enquanto que as menores produtividades foram obtidas para as cultivares Markies $\left(28.624 \mathrm{~kg} \mathrm{ha}^{-1}\right)$ e Atlantic (22.544 $\mathrm{kg} \mathrm{ha}^{-1}$ ). Feltran (2002), na safra das águas em São Manoel-SP, obteve produtividades de 39.500; 16.000 e $23.400 \mathrm{~kg} \mathrm{ha}^{-1}$ para as cultivares Mondial, Asterix e Ágata, respectivamente. Já Yorinori (2003) trabalhando com a cultivar Atlantic em duas safras, observou produtividades superiores a obtida no presente experimento para a mesma cultivar, sendo de $36.500 \mathrm{~kg} \mathrm{ha}^{-1}$ na safra das águas e $24.000 \mathrm{~kg} \mathrm{ha}^{-1}$ na safra das secas.

Com relação à produtividade de tubérculos comercializáveis, os resultados foram semelhantes aos obtidos para a produtividade total, sendo que todas as cultivares apresentaram a maior parte dos tubérculos classificados como comercializáveis (Tabela 5). Embora as cultivares Mondial, Asterix e Ágata tenham apresentado as maiores produtividades total e comercial, a cultivar Mondial apresentou maior produtividade de tubérculos da classe "graúda", enquanto a produtividade de tubérculos da classe "primeira" foi maior nas cultivares Asterix e Ágata (Tabela 5).

Verificou-se que na produtividade de tubérculos da classe "segunda", as cultivares Ágata, Asterix e Mondial apresentaram produtividades semelhantes e superiores às apresentadas pelas cultivares Atlantic e Markies (Tabela 5). No entanto, a produtividade de tubérculos miúdos (descarte) foi menor nas cultivares Atlantic e Markies. 
Tabela 5. Produtividade total, comercial e por classes (especial, primeira, segunda e miúda) de tubérculos das cultivares de batata na safra de inverno.

\begin{tabular}{lcccccc}
\hline \multirow{2}{*}{ Cultivares } & Total & $\begin{array}{c}\text { Comercial } \\
(>23 \mathrm{~mm})^{(1)}\end{array}$ & $\begin{array}{c}\text { Graúda } \\
(>45 \mathrm{~mm})\end{array}$ & $\begin{array}{c}\text { Primeira } \\
(33 \mathrm{a} 45 \mathrm{~mm})\end{array}$ & $\begin{array}{c}\text { Segunda } \\
(23 \mathrm{a} \mathrm{33} \mathrm{mm})\end{array}$ & $\begin{array}{c}\text { Miúda } \\
(<23 \mathrm{~mm})\end{array}$ \\
\cline { 2 - 7 } Ágata & $37.268 \mathrm{~b}$ & $37.062 \mathrm{~b}$ & $22.933 \mathrm{c}$ & $12.798 \mathrm{a}$ & $1.330 \mathrm{a}$ & $206 \mathrm{a}$ \\
Asterix & $40.002 \mathrm{ab}$ & $39.818 \mathrm{ab}$ & $25.451 \mathrm{~b}$ & $13.205 \mathrm{a}$ & $1.160 \mathrm{a}$ & $184 \mathrm{ab}$ \\
Atlantic & $22.544 \mathrm{~d}$ & $22.517 \mathrm{~d}$ & $17.712 \mathrm{~d}$ & $4.456 \mathrm{c}$ & $347 \mathrm{c}$ & $27 \mathrm{~d}$ \\
Markies & $28.624 \mathrm{c}$ & $28.529 \mathrm{c}$ & $19.658 \mathrm{~d}$ & $8.129 \mathrm{~b}$ & $740 \mathrm{~b}$ & $95 \mathrm{c}$ \\
Mondial & $40.908 \mathrm{a}$ & $40.748 \mathrm{a}$ & $32.113 \mathrm{a}$ & $7.424 \mathrm{~b}$ & $1.209 \mathrm{a}$ & $160 \mathrm{~b}$ \\
CV $(\%)$ & 4,1 & 4,1 & 4,6 & 12,6 & 9,5 & 9,8 \\
\hline \multicolumn{2}{l}{ Médias seguidas de mesma letra, nas colunas, não diferem entre si pelo teste Tukey a 5\% de probabilidade. ${ }^{(1)}$} \\
Classificação segundo o diâmetro transversal dos tubérculos.
\end{tabular}

\subsection{Estado nutricional das plantas}

$\mathrm{Na}$ Tabela 6, encontram-se os resultados dos teores foliares dos nutrientes obtidos aos 30 DAE na terceira folha a partir do tufo apical das diferentes cultivares de batata.

Em relação ao $\mathrm{N}$ (Tabela 6), houve diferença significativa entre Markies e as cultivares Ágata, Asterix e Atlantic, sendo os maiores teores foliares encontrados em Markies (59 $\mathrm{g} \mathrm{kg}^{-1}$ ). Todas as cultivares estudadas, apresentaram teores foliares de $\mathrm{N}$ superiores a faixa considerada adequada por Lorenzi et al. (1997), que é de 40 a $50 \mathrm{~g} \mathrm{~kg}^{-1} \mathrm{de}$ N. No entanto, Jones Junior (1991) propôs como adequado, para o nutriente N, o intervalo de 45 a $60 \mathrm{~g} \mathrm{~kg}^{-1}$, no qual, todas as cultivares estudadas se enquadraram.

Quanto ao P, destacou-se com maior teor a cultivar Mondial $\left(6,1 \mathrm{~g} \mathrm{~kg}^{-}\right.$ ${ }^{1}$ ), enquanto a cultivar Atlantic (4,6 $\mathrm{g} \mathrm{kg}^{-1}$ ) apresentou o menor valor (Tabela 6). Apenas a cultivar Atlantic, mostrou valores dentro da faixa descrita como adequada por Jones Junior (1991) e Lorenzi et al. (1997) e os teores foliares observados nas demais cultivares situaram-se acima destas faixas. A ocorrência de teores foliares de $\mathrm{P}$ superiores ao do intervalo recomendado por estes autores se justifica pelo fato do solo já conter um teor considerado alto 
de P (RAIJ et al., 1997) (Tabela 1) e ter sido utilizada elevada dose de P na adubação de plantio.

Tabela 6. Teores foliares dos nutrientes N, P, K, Ca, Mg, S, B, Cu, Fe, Mn e Zn, aos 30 dias após a emergência, de cultivares de batata.

\begin{tabular}{|c|c|c|c|c|c|c|}
\hline Cultivares & $\mathrm{N}$ & $\mathrm{P}$ & K & $\mathrm{Ca}$ & $\mathrm{Mg}$ & $\mathrm{S}$ \\
\hline Ágata & $53 b$ & $5,3 b c$ & $82 a$ & $17,4 a b$ & $3,7 \mathrm{ab}$ & $2,7 \mathrm{a}$ \\
\hline Asterix & $51 b$ & $5,1 b c$ & $71 \mathrm{a}$ & $16,4 \mathrm{ab}$ & $3,7 \mathrm{ab}$ & $1,7 \mathrm{~b}$ \\
\hline Atlantic & $52 b$ & $4,6 c$ & $68 \mathrm{a}$ & $15,7 \mathrm{ab}$ & $3,7 \mathrm{ab}$ & $2,1 a b$ \\
\hline Markies & $59 a$ & $5,5 a b$ & $65 a$ & $19,7 \mathrm{a}$ & $4,6 \mathrm{a}$ & $2,0 \mathrm{~b}$ \\
\hline Mondial & $57 \mathrm{ab}$ & $6,1 \mathrm{a}$ & $73 a$ & $12,2 b$ & $3,5 b$ & $1,9 b$ \\
\hline \multirow[t]{2}{*}{$\mathrm{CV} \%$} & 4,7 & 5,9 & 11,2 & 19,8 & 12,0 & 14,4 \\
\hline & $\mathrm{B}$ & $\mathrm{Cu}$ & \multicolumn{2}{|c|}{$\mathrm{Fe}$} & $\mathrm{Mn}$ & $\mathrm{Zn}$ \\
\hline & & & \multicolumn{2}{|c|}{$\mathrm{mg} \mathrm{kg}^{-1}$} & & \\
\hline Ágata & $54 a b$ & $41 \mathrm{ab}$ & & \multicolumn{2}{|c|}{$449 a$} & $76 a$ \\
\hline Asterix & $59 \mathrm{ab}$ & $55 a$ & & \multicolumn{2}{|c|}{$436 a$} & $73 a$ \\
\hline Atlantic & $41 b$ & $31 b$ & & \multicolumn{2}{|c|}{$453 a$} & $63 a$ \\
\hline Markies & $43 b$ & $30 \mathrm{~b}$ & & \multicolumn{2}{|c|}{$435 a$} & $66 a$ \\
\hline Mondial & $65 a$ & $27 b$ & & \multicolumn{2}{|c|}{$351 a$} & $83 a$ \\
\hline $\mathrm{CV} \%$ & 18,4 & 26,7 & & \multicolumn{2}{|c|}{11,3} & 13,1 \\
\hline
\end{tabular}

Médias seguidas de mesma letra, nas colunas, não diferem entre si pelo teste Tukey a 5\% de probabilidade.

Não foram observadas diferenças estatísticas entre as cultivares quanto ao teor de $\mathrm{K}$ nas folhas (Tabela 6). Os teores foliares de $\mathrm{K}$ apresentados pela cultivar Markies estavam dentro da faixa de teores considerados adequados por Lorenzi et al. (1997). Já nas demais cultivares os teores de $\mathrm{K}$ ficaram acima desta faixa, e abaixo da faixa de 93 a $115 \mathrm{~g} \mathrm{~kg}^{-}$ ${ }^{1}$, considerada adequada por Jones Junior (1991), embora, o solo apresentasse altos teores de K (RAIJ et al., 1997) (Tabela 1). No entanto, a cultivar Ágata apresentou teor foliar semelhante ao intervalo considerado adequado por Reis Junior (1995) de 74 a $89 \mathrm{~g} \mathrm{~kg}^{-1}$ de K que, segundo esse autor, garante de 99 a 100\% da produção.

Diferenças entre os teores foliares de $\mathrm{Ca}$ foram obtidas apenas entre as cultivares Markies (19,7 $\left.\mathrm{g} \mathrm{kg}^{-1}\right)$ e Mondial (12,2 $\left.\mathrm{g} \mathrm{kg}^{-1}\right)$, enquanto que entre as demais cultivares não foram constatadas diferenças significativas. Os teores foliares de $\mathrm{Ca}$ em todas as cultivares enquadraram-se no intervalo descrito como adequado por Lorenzi et al. (1997) que é de 10 a $20 \mathrm{~g} \mathrm{~kg}^{-1}$, porém, acima da faixa considerada adequada (7,6 a $\left.10 \mathrm{~g} \mathrm{~kg}^{-1}\right)$ por Jones Junior (1991). 
Quanto ao $\mathrm{Mg}$, o teor mais elevado e o menor teor foram obtidos nas cultivares Markies (4,6 $\mathrm{g} \mathrm{kg}^{-1}$ ) e Mondial (3,5 $\mathrm{g} \mathrm{kg}^{-1}$ ), respectivamente. No entanto, todas as cultivares apresentaram teores foliares de $\mathrm{Mg}$ compatíveis com o intervalo considerado adequado por Lorenzi et al. (1997) (3 a $5 \mathrm{~g} \mathrm{~kg}^{-1}$ ) e, inferiores aos descritos por Jones Junior (1991) (10 a $\left.12 \mathrm{~g} \mathrm{~kg}^{-1}\right)$.

O maiores teores foliares de $\mathrm{S}$ foram observados nas cultivares Ágata $\left(2,7 \mathrm{~g} \mathrm{~kg}^{-1}\right)$ e Atlantic (2,1 $\left.\mathrm{g} \mathrm{kg}^{-1}\right)$ (Tabela 6). Embora os teores de $\mathrm{S}_{-} \mathrm{SO}_{4}{ }^{2-}$ no solo encontravam-se altos (>10 $\mathrm{mg} \mathrm{dm}^{-3}$ ) segundo Raij et al. (1997) (Tabela 1) apenas a cultivar Ágata apresentou teores foliares de $\mathrm{S}$ dentro do intervalo considerado adequado $(2,5$ a 5,0 g $\mathrm{kg}^{-1}$ ) por Lorenzi et al. (1997), enquanto, nas demais cultivares os teores foram inferiores ao intervalo relatado por esse autor. Isso provavelmente, ocorreu devido à alta disponibilidade de fosfato no solo (Tabela 1), que por também ser um ânion, pode ter interferido na absorção do sulfato.

Para o micronutriente B, as cultivares Mondial, Asterix e Ágata não diferiram entre si e apresentaram os maiores valores de 65,59 e $54 \mathrm{mg} \mathrm{kg}^{-1}$, respectivamente. Os teores foliares de B observados nessas cultivares são superiores aos relatados como

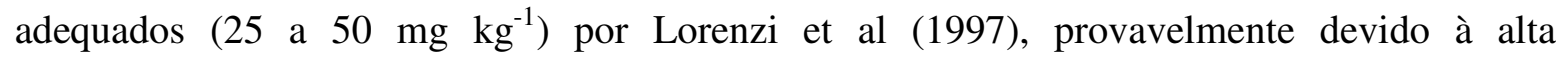
disponibilidade de B no solo (Tabela 1). Dentre as culivares estudadas somente Atlantic e Markies se enquadraram na faixa de 25 a $50 \mathrm{mg} \mathrm{kg}^{-1}$ de $\mathrm{B}$, proposta como adequada por Jones Junior (1991) e Lorenzi et al. (1997).

No que se refere ao $\mathrm{Cu}$, a cultivar Asterix apresentou os maiores teores foliares, $55 \mathrm{mg} \mathrm{kg}^{-1}$, e superiores aos obtidos nas cultivares Atlantic, Markies e Mondial (Tabela 6). No entanto, todas as cultivares estudadas obtiveram teores foliares de $\mathrm{Cu}$ superiores ao intervalo proposto como adequado por Jones Junior (1991) e Lorenzi et al. (1997), que é de 7 a $20 \mathrm{mg} \mathrm{kg}^{-1}$.

Não houve diferença entre as cultivares quantos aos teores foliares de Fe, Mn e Zn (Tabela 6). No entanto, todas as cultivares apresentaram teores foliares acima da faixa descrita como adequada por Jones Junior (1991) e Lorenzi et al. (1997) para os micronutrientes Fe e Mn, a qual é de 50 a $100 \mathrm{mg} \mathrm{kg}^{-1}$ de Fe e 30 a $250 \mathrm{mg} \mathrm{kg}^{-1}$ de Mn. Os teores foliares de $\mathrm{Zn}$ observados em todas cultivares enquadraram-se dentro do intervalo considerado adequado por Jones Junior (1991), que é de 45 a $250 \mathrm{mg} \mathrm{kg}^{-1}$. O fato de todos os 
micronutrientes catiônicos $(\mathrm{Cu}, \mathrm{Fe}, \mathrm{Zn}$ e $\mathrm{Mn})$ terem apresentado teores foliares acima faixa descrita como adequada por Lorenzi et al. (1997), provavelmente está relacionado como o fato do solo estar em uma condição de baixo $\mathrm{pH}$, que sabidamente aumenta a disponibilidade desses elementos podendo ser comprovado pelos altos teores desses elementos no solo (RAIJ et al., 1997) (Tabela 1).

\subsection{Marcha de absorção de macronutrientes}

\subsubsection{Nitrogênio}

Em todas as cultivares estudadas, os maiores teores de $\mathrm{N}$ ocorreram na seguinte ordem: folhas, raízes, hastes, tubérculos e tubérculos-semente (Tabela 7). De maneira geral, os maiores teores de $\mathrm{N}$ nos tubérculos-semente foram observados nas amostras coletadas no momento do plantio, enquanto, nas raízes, hastes e folhas os teores mais elevados desse elemento foram observados na primeira coleta, aos 20 DAP. Nos tubérculos os maiores teores de $\mathrm{N}$ foram observados no início de seu desenvolvimento, ou seja, aos 34 DAP. A partir do plantio a redução no teor de $\mathrm{N}$ nos tubérculos-semente ocorreu principalmente devido à remobilização desse nutriente para as regiões de crescimento, enquanto, nos demais órgãos das plantas essa redução ocorreu em função da diluição, já que houve crescimento rápido das plantas com aumento contínuo de MS (Figura 5). Nas últimas três amostragens, os teores de N nos tubérculos permaneceram relativamente constantes, provavelmente, em função da menor taxa de crescimento dos mesmos, ou seja, do menor acúmulo de MS (Figura 5E). Os valores obtidos para teor de $\mathrm{N}$ nas diferentes partes das plantas foram semelhantes àqueles obtidos por Gargantini et al. (1963) e Paula et al. (1986).

Entre os órgãos das plantas, os maiores acúmulos de $\mathrm{N}$ ocorreram nos tubérculos, seguido das folhas, hastes, tubérculos-semente (primeiras avaliações) e raízes (Figura 8). 
Tabela 7. Teor de $\mathrm{N}$ em cada parte das plantas de cultivares de batata ao longo do ciclo da cultura.

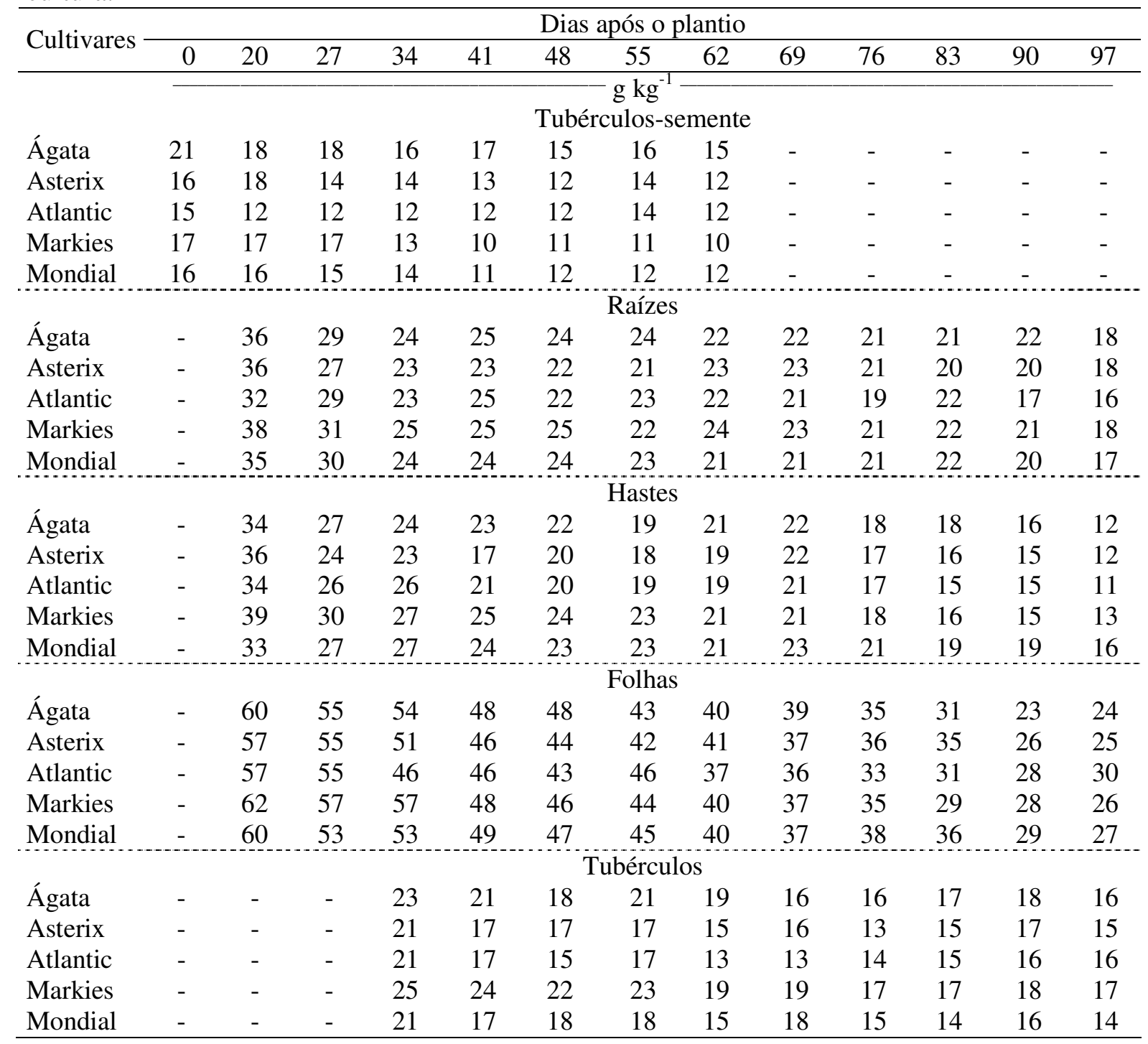



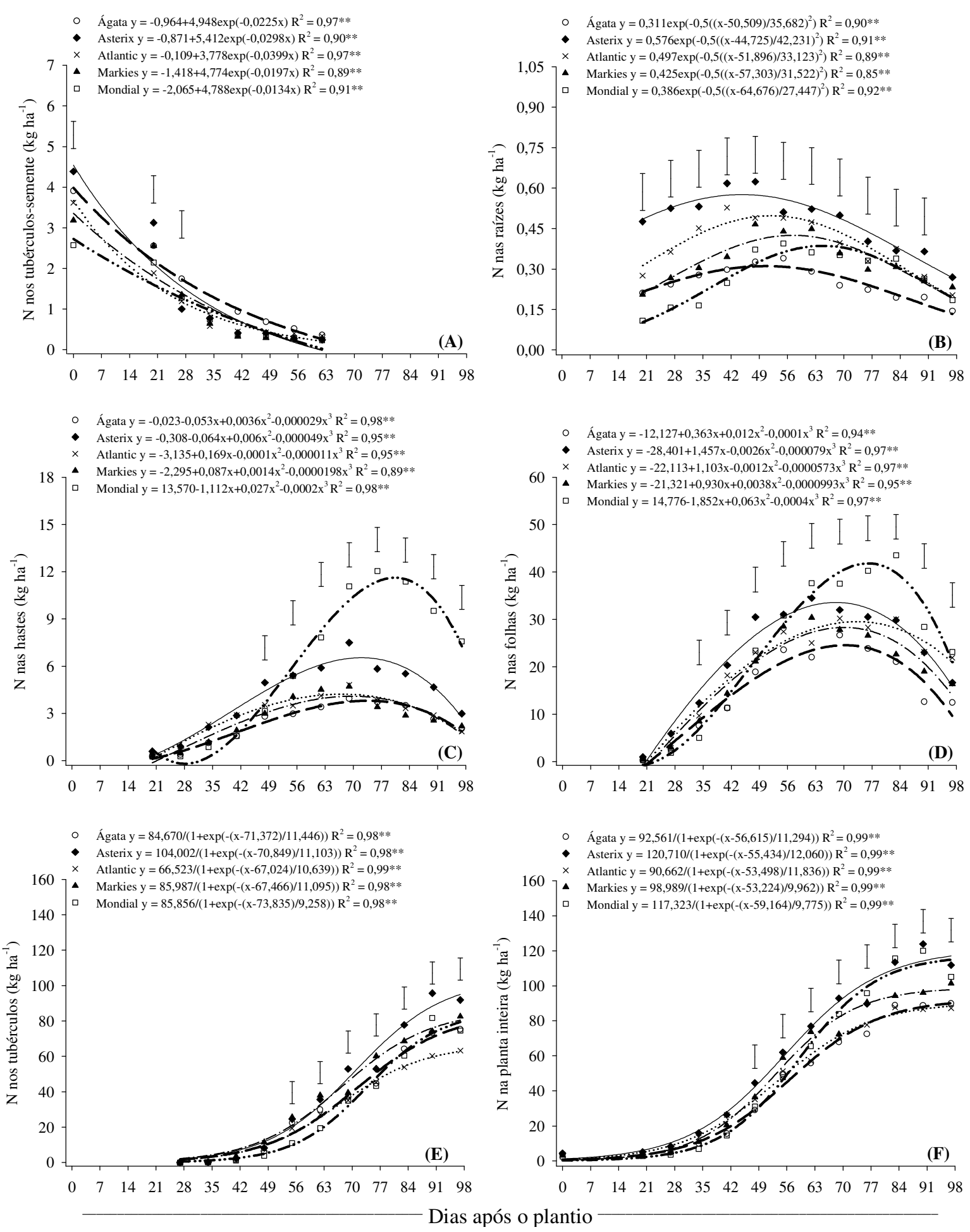

Figura 8. Quantidade de $\mathrm{N}$ nos tubérculos-semente (A), raízes (B), hastes (C), folhas (D), tubérculos $(\mathrm{E})$ e na planta inteira $(\mathrm{F})$ de cultivares de batata ao longo do ciclo. $* *$ significativo a $1 \%$ de probabilidade pelo teste F. Barras verticais indicam o valor de DMS pelo testeTukey a $5 \%$ de probabilidade. 
$\mathrm{O} \mathrm{N}$ presente nos tubérculos-semente diminuiu com o decorrer do ciclo de desenvolvimento das plantas (Figura 8A). No momento do plantio a cultivar Asterix apresentou quantidades de $\mathrm{N}$ nos tubérculos-semente superiores às observadas nas cultivares Atlantic, Markies e Mondial, enquanto que aos 20 DAP, essa diferença foi observada apenas entre as cultivares Asterix, Mondial e Atlantic. No entanto, a maior redução da quantidade de $\mathrm{N}$ dos tubérculos-semente da cultivar Asterix aos 27 DAP, proporcionou menores quantidades de $\mathrm{N}$ nos tubérculos-semente dessa cultivar em comparação à Ágata. Embora, a cultivar Atlantic tenha apresentado MS de tubérculos-semente semelhante à Asterix e superior à Ágata na primeira avaliação (Figura 5A), a quantidade de $\mathrm{N}$ nos tubérculos-semente da Atlantic foi semelhante à observada na Ágata. Isso ocorreu devido aos maiores teores de $\mathrm{N}$ observados nos tubérculos-semente da cultivar Ágata (Tabela 7). A partir dos 34 DAP, a redução da quantidade de $\mathrm{N}$ nos tubérculos-semente ocorreu de forma semelhante entre todas as cultivares estudadas. As diminuições nas quantidades de $\mathrm{N}$ dos tubérculos-semente durante $\mathrm{o}$ crescimento das plantas, se explica em grande parte pela redução da MS dos mesmos (Figura 5A), bem como, pela remobilização e translocação do $\mathrm{N}$ dos tubérculos-semente para os órgãos das plantas em crescimento, uma vez que, houve reduções no teor de $\mathrm{N}$ no referido órgão (Tabela 7) e, pelo fato desse elemento ser passível de redistribuição entre os órgãos das plantas (MALAVOLTA, 2006).

Os acúmulos de $\mathrm{N}$ nas raízes aumentaram inicialmente de forma semelhante ao observado para a MS, atingindo os máximos acúmulos estimados de $0,57,0,45$, 0,42, 0,38 e 0,31 $\mathrm{kg} \mathrm{ha}^{-1}$ aos 45,51,56, 64, 48 DAP, respectivamente, para as cultivares Asterix, Atlantic, Markies, Mondial e Ágata (Figura 8B). Da emergência até os 27 DAP, a cultivar Asterix apresentou os maiores acúmulos de $\mathrm{N}$ nas raízes, sendo que a partir dos 34 DAP intensificou-se o acúmulo de $\mathrm{N}$ nas raízes da cultivar Atlantic, ocasionando o acúmulo semelhante desse elemento nas raízes dessas cultivares. Dos 48 DAP até o final do ciclo o acúmulo de $\mathrm{N}$ nas raízes de cultivar Markies foi semelhante ao obtido nas cultivares Asterix e Atlantic. No entanto, durante a fase de enchimento dos tubérculos (42 a 90 DAP) houve redução do acúmulo de $\mathrm{N}$ nas raízes de todas as cultivares estudadas, sendo observadas diferenças apenas entre as cultivares Asterix e Ágata, as quais apresentaram os maiores e menores acúmulos, respectivamente. $\mathrm{Na}$ última avaliação todas as cultivares apresentaram quantidades semelhantes de $\mathrm{N}$ acumuladas nas raízes. No final do ciclo, as diminuições das 
quantidades de $\mathrm{N}$ acumuladas nas raízes de todas as cultivares, estão relacionadas com a morte e redução da MS do sistema radicular (Figura 5B), bem como, devido à remobilização desse elemento para outras partes da planta, uma vez que houve redução dos teores de $\mathrm{N}$ no referido órgão (Tabela 7).

Nas hastes, os dados referentes ao acúmulo de $\mathrm{N}$ foram ajustados a modelos cúbicos de regressão (Figura $8 \mathrm{C}$ ). Da emergência até aos 41 DAP o acúmulo de $\mathrm{N}$ pelas hastes foi crescente e não diferiu entre as cultivares, porém, a partir dos 48 DAP o acúmulo de $\mathrm{N}$ nas hastes intensificou-se de forma diferente entre as cultivares. As quantidades máximas de $\mathrm{N}$ acumuladas nas hastes foram estimadas em 3,8, 6,5, 4,2, 4,1 e 11,6 kg ha ${ }^{-1} \mathrm{e}$, ocorreram aos 73, 72, 67, 69 e 80 DAP, respectivamente, para as cultivares Ágata, Asterix, Atlantic, Markies e Mondial. A partir dos 62 DAP até o final do ciclo as maiores quantidades de $\mathrm{N}$ nas hastes foram verificadas na cultivar Mondial. No período de 69 a 90 DAP as quantidades de $\mathrm{N}$ acumuladas nas hastes da cultivar Asterix, apesar de terem sido inferiores às obtidas pela cultivar Mondial, foram superiores às das demais cultivares. Os maiores acúmulos de $\mathrm{N}$ observados nas cultivares Mondial e Asterix após os 69 DAP, devem-se ao maior acúmulo de MS nas hastes dessas cultivares (Figura 5C).

Os dados referentes ao acúmulo de $\mathrm{N}$ nas folhas foram ajustados a modelos cúbicos de regressão (Figura $8 \mathrm{D}$ ). Os acúmulos de $\mathrm{N}$ nas folhas foram pequenos e semelhantes entre as cultivares até aos 27 DAP, coincidindo com o período de menor acúmulo de MS. A partir dos 34 DAP os acúmulos de $\mathrm{N}$ nas folhas intensificaram-se, alcançando as quantidades máximas estimadas de 24,5, 33,6, 29,5, 28,3 e 41,8 $\mathrm{kg} \mathrm{ha}^{-1}$, aos 70, 68, 73, 70, e 76 DAP, respectivamente, nas cultivares Ágata, Asterix, Atlantic, Markies e Mondial. Semelhante ao ocorrido para a MS (Figura 5D), os maiores acúmulos de N nas folhas foram observados na cultivar Mondial entre 69 e 90 DAP. No entanto, durante esse mesmo período os menores acúmulos foram observados na cultivar Ágata. $\mathrm{Na}$ última avaliação, as cultivares Atlantic e Mondial apresentaram quantidades semelhantes de $\mathrm{N}$ acumuladas nas folhas (Figura 8D), que ocorreu devido aos maiores teores desse elemento nas folhas de Atlantic, pois, a MS foliar da Atlantic foi inferior à da Mondial (Tabela 7 e Figura 5D). A queda de folhas constatada pela redução do número de folhas e da MS foliar (Figuras 3B e 5D), além da translocação do $\mathrm{N}$ das folhas para os tubérculos (redução do teor) (Tabela 7), proporcionou 
diminuições nas quantidades de $\mathrm{N}$ acumuladas nas folhas de todas as cultivares na fase final do ciclo (Figura 8D).

Nos tubérculos os dados referentes ao acúmulo de $\mathrm{N}$ ajustaram-se a modelos sigmóides (Figura 8E). Observa-se que durante a fase de tuberização (35 a 41 DAP) os acúmulos de $\mathrm{N}$ nos tubérculos de todas as cultivares foram pequenos e semelhantes, mas à medida que iniciou-se a fase de enchimento de tubérculos (42 a 90 DAP), houve aumento contínuo dos acúmulos de $\mathrm{N}$ nos tubérculos de todas as cultivares estudadas até o final do ciclo. Entre os 55 e 62 DAP, os tubérculos das cultivares Asterix e Markies apresentaram acúmulo de $\mathrm{N}$ superior ao obtido na cultivar Mondial (Figura 8E), o que pode ser explicado pelas maiores taxas diárias de acúmulo de $\mathrm{N}$ nos tubérculos dessas cultivares durante esse período (Figura 9A). Entre 83 e 97 DAP as quantidades de $\mathrm{N}$ acumuladas nos tubérculos das cultivares Markies e Mondial foram semelhantes, o que é reflexo do aumento constante da quantidade de $\mathrm{N}$ acumulada nos tubérculos da cultivar Mondial nesse período. Esse aumento no acúmulo de $\mathrm{N}$ dos tubérculos da cultivar Mondial, no final do ciclo, foi obtido devido às maiores taxas diárias de acúmulo de $\mathrm{N}$ nos tubérculos dessa cultivar, ocorridas nessa época (Figura 9A). No final do ciclo os tubérculos da cultivar Asterix apresentaram os maiores acúmulos de $\mathrm{N}$, enquanto, os menores acúmulos foram observados na cultivar Atlantic. $\mathrm{O}$ maior acúmulo de $\mathrm{N}$ observado nos tubérculos da cultivar Asterix em comparação a Atlantic, é resultado do maior acúmulo de MS nos tubérculos dessa cultivar (Figura 5E), uma vez que, não foram observadas grandes variações entre as cultivares quanto ao teor de $\mathrm{N}$ nos tubérculos (Tabela 7).

Embora, os tubérculos tenham acumulado $\mathrm{N}$ durante todo o ciclo, a época de maior taxa de acúmulo desse nutriente nos tubérculos ocorreu entre 67 e 74 DAP, período esse, em que as taxas diárias de acúmulo de $\mathrm{N}$ nos tubérculos atingiram os valores máximos estimados de 1,85; 2,34; 1,56; 1,94; e 2,32 $\mathrm{kg} \mathrm{ha}^{-1} \mathrm{dia}^{-1}$ nas cultivares Ágata, Asterix, Atlantic, Markies e Mondial, respectivamente (Figura 9A e Tabela 8). No final do ciclo, as quantidades máximas de $\mathrm{N}$ acumuladas nos tubérculos foram estimadas em 76, 95, 63, 80 e 79 $\mathrm{kg} \mathrm{ha}^{-1}$, respectivamente, pelas cultivares Ágata, Asterix, Atlantic, Markies e Mondial (Figura $8 \mathrm{E})$.

Da quantidade total máxima de $\mathrm{N}$ acumulada nas plantas (Figura $8 \mathrm{~F}$ ), os tubérculos das cultivares Asterix, Markies e Ágata acumularam entre $81 \%$ e $84 \%$ e os 
tubérculos das cultivares Mondial e Atlantic entre $68 \%$ e 71\% (Figura 8E). Esses dados estão de acordo com os obtidos por Paula et al. (1986) em estudo sobre a produção de MS e absorção de macronutrientes por cultivares de batata, no qual observou-se que os tubérculos das cultivares Achat e Mantiqueira acumularam em torno de $88 \%$ e $80 \%$ do total de $\mathrm{N}$ absorvido.
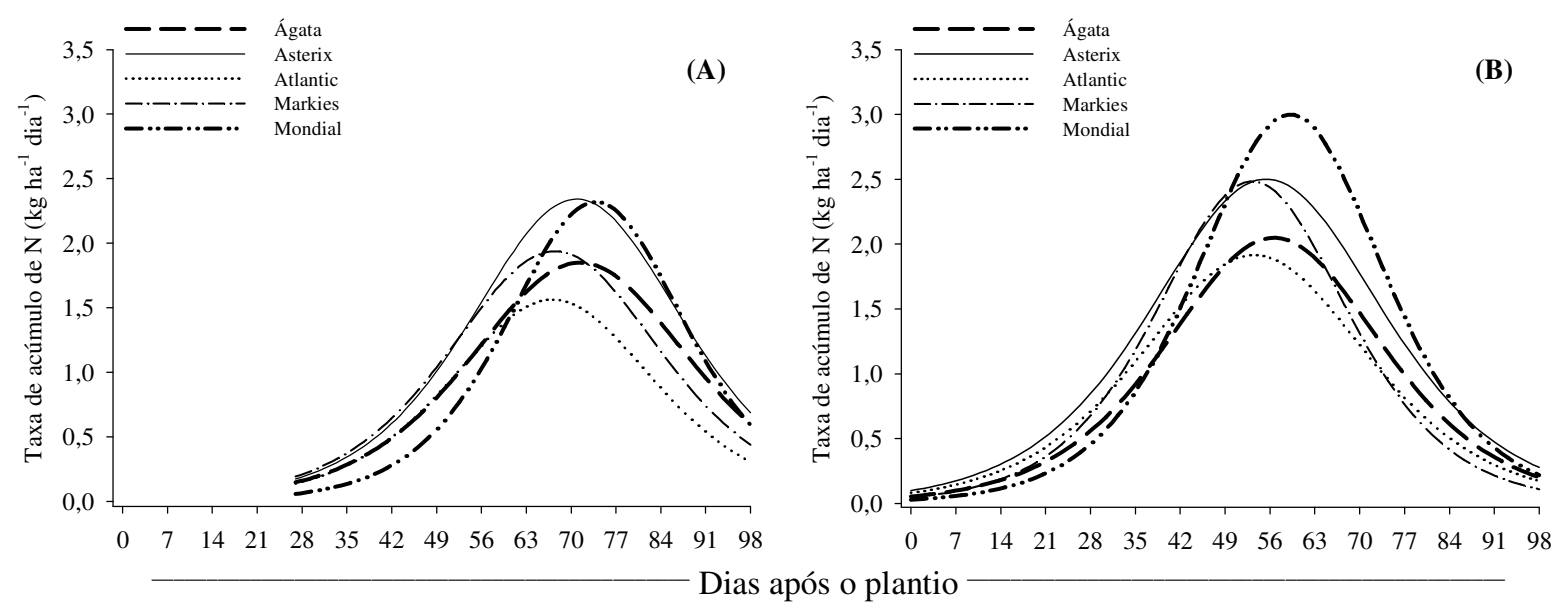

Figura 9. Taxa de acúmulo de $\mathrm{N}$ nos tubérculos (A) e nas plantas (B) de cultivares de batata ao longo do ciclo.

Tabela 8. Quantidade máxima de $\mathrm{N}$ acumulada, taxa diária máxima de acúmulo e época de maior taxa de acúmulo de $\mathrm{N}$ nos tubérculos e nas plantas de cultivares de batata.

\begin{tabular}{|c|c|c|c|c|c|c|}
\hline Cultivares & $\begin{array}{l}\text { Acúmulo } \\
\text { máximo no } \\
\text { tubérculo }\end{array}$ & $\begin{array}{c}\text { Taxa } \\
\text { máxima de } \\
\text { acúmulo no } \\
\text { tubérculo }\end{array}$ & $\begin{array}{c}\text { Época de } \\
\text { maior taxa } \\
\text { de acúmulo } \\
\text { no tubérculo }\end{array}$ & $\begin{array}{l}\text { Acúmulo } \\
\text { máximo na } \\
\text { planta }\end{array}$ & $\begin{array}{c}\text { Taxa } \\
\text { máxima de } \\
\text { acúmulo na } \\
\text { planta }\end{array}$ & $\begin{array}{c}\text { Época de } \\
\text { maior taxa de } \\
\text { acúmulo na } \\
\text { planta }\end{array}$ \\
\hline & $\mathrm{kg} \mathrm{ha}^{-1}$ & $\mathrm{~kg} \mathrm{ha}^{-1} \mathrm{dia}^{-1}$ & DAP & $\mathrm{kg} \mathrm{ha}^{-1}$ & $\mathrm{~kg} \mathrm{ha}^{-1} \mathrm{dia}^{-1}$ & DAP \\
\hline Ágata & 76 & 1,85 & 71 & 90 & 2,04 & 55 \\
\hline Asterix & 95 & 2,34 & 71 & 117 & 2,50 & 55 \\
\hline Atlantic & 63 & 1,56 & 67 & 88 & 1,91 & 53 \\
\hline Markies & 80 & 1,94 & 67 & 98 & 2,48 & 52 \\
\hline Mondial & 79 & 2,32 & 74 & 115 & 2,99 & 58 \\
\hline
\end{tabular}

Os dados de acúmulo de $\mathrm{N}$ na planta inteira ajustaram-se a modelos sigmóides de regressão (Figura 8F). Nos primeiros 41 DAP, o acúmulo de N pelas plantas foi pequeno e não diferiu entre as cultivares, coincidindo com o período de menor acúmulo de MS. O pequeno acúmulo de $\mathrm{N}$ nas fases iniciais de desenvolvimentos das plantas ocorreu devido a pequena absorção, principalmente, durante a fase de crescimento vegetativo uma vez 
que as taxas diárias de absorção eram baixas e, todas as cultivares tinham absorvido menos de 17\% da exigência total (Figura 9B e Tabela 9). Esses dados estão de acordo com os relatos de Ojala et al. (1990), de que a batateira (cv. 'Russet Burbank') requer baixa quantidade de N durante o crescimento vegetativo, em torno de $15 \%$ da necessidade total, e que a deficiência de $\mathrm{N}$ durante essa fase pode ser corrigida rapidamente com a adubação de cobertura seguida de irrigação. A partir dos 48 DAP o acúmulo de $\mathrm{N}$ intensificou-se de forma contínua e diferente entre as cultivares até o final do ciclo, atingindo, aos 97 DAP os acúmulos máximos estimados de 90, 117, 88, 98 e $115 \mathrm{~kg} \mathrm{ha}^{-1}$ nas cultivares Ágata, Asterix, Atlantic, Markies e Mondial, respectivamente (Figura 8F e Tabela 8). Yorinori (2003) em estudo sobre o crescimento e o acúmulo de nutrientes pela batateira, cultivar Atlantic, observou acúmulos totais de $\mathrm{N}$ de 140 $\mathrm{kg} \mathrm{ha}^{-1}$ (safra das águas) e $119 \mathrm{~kg} \mathrm{ha}^{-1}$ (safra das secas), ou seja, superiores aos obtidos no presente experimento. Entre 83 e 90 DAP, as maiores quantidades acumuladas de $\mathrm{N}$ foram observadas nas cultivares Asterix e Mondial, em função das maiores taxas diárias de absorção (Figura 9B e Tabela 8) e dos maiores acúmulos de MS apresentados por essas cultivares (Figura 5F). Nesse mesmo período as menores quantidades de $\mathrm{N}$ foram observadas nas cultivares Markies, Ágata e Atlantic, o que é reflexo do menor acúmulo de MS (Figura 5F), bem como, das menores taxas diárias de absorção (Figura 9B e Tabela 8). No entanto, o aumento notado no acúmulo de $\mathrm{N}$ apresentado pela cultivar Markies aos $97 \mathrm{DAP}$, que refletiu em ausência de diferenças significativas entre as cultivares Markies, Mondial e Asterix, se explica em grande parte, pelo maior teor de $\mathrm{N}$ nos tubérculos dessa cultivar na última avaliação (Tabela 7), uma vez que, nesse período a MS total dos tubérculos representava mais de $85 \%$ da MS total da planta (Tabela 3) e o acúmulo de MS pela cultivar Markies foi menor que o observado em Asterix e Mondial (Figura 5F).

Durante todo o estádio de enchimento dos tubérculos (42 a 90 DAP), as cultivares absorveram em média $77 \%$ da quantidade total de $\mathrm{N}$ (Tabela 9). Estudos realizados por Yorinori (2003) demonstraram resultados semelhantes, ou seja, absorção de $60 \%$ do total na fase de enchimento dos tubérculos, durante a safra das águas, e a absorção de $76 \%$ do total no mesmo período, na safra das secas. No entanto, a época de maior demanda por $\mathrm{N}$ em todas as cultivares estudadas ocorreu entre 42 e 62 DAP, ou seja, no início da fase de enchimento de tubérculos, quando as cultivares absorveram aproximadamente $44 \%$ da absorção total (Tabela 9). Embora durante todo este período a demanda por $\mathrm{N}$ tenha sido alta, 
esta acentuou-se ainda mais entre 52 e 58 DAP quando ocorreram as maiores taxas diárias de absorção (Figura 9B e Tabela 8). Nota-se que as taxas diárias de absorção de $\mathrm{N}$ pelas plantas foram crescentes e maiores que as taxas de acúmulo de $\mathrm{N}$ nos tubérculos até em torno dos $52 \mathrm{a}$ 58 DAP, sofrendo reduções após esse período. No entanto, no período compreendido entre 67 e 74 DAP, quando as taxas de absorção já tinham diminuído, ocorreram as maiores taxas diárias de acúmulo de $\mathrm{N}$ nos tubérculos, indicando que em média, 15 dias após a ocorrência das máximas taxas diárias de absorção, têm-se o período de maior redistribuição do $\mathrm{N}$ das raízes, hastes e folhas para os tubérculos. Esse fato pode ser comprovado pela redução dos teores e das quantidades acumuladas de $\mathrm{N}$ nas raízes, hastes e folhas de todas as cultivares durante a fase final do ciclo (Tabela 7 e Figura 8).

Tabela 9. Percentual de $\mathrm{N}$ acumulado pelas plantas em cada fase do desenvolvimento das cultivares de batata (valores obtidos nas equações ajustadas).

\begin{tabular}{|c|c|c|c|c|c|}
\hline \multirow{3}{*}{ Cultivares } & \multicolumn{5}{|c|}{ Dias após o plantio/Fase da cultura } \\
\hline & $0-34$ & $35-41$ & $42-62$ & $63-90$ & 91-97 \\
\hline & Crescimento vegetativo & Iuberızaçao & Enchim & iberculos & Maturaçăo \\
\hline Ágata & 13 & 8 & 43 & 34 & 2 \\
\hline Asterix & 15 & 9 & 42 & 32 & 2 \\
\hline Atlantic & 16 & 10 & 43 & 29 & 2 \\
\hline Markies & 13 & 10 & 49 & 27 & 1 \\
\hline Mondial & 7 & 7 & 45 & 39 & 2 \\
\hline
\end{tabular}

\subsubsection{Fósforo}

De maneira geral, os maiores teores de $\mathrm{P}$, em todos os órgãos das plantas, foram observados nas primeiras avaliações (Tabela 10). Até aos 27 DAP os maiores teores de $\mathrm{P}$ foram observados na seguinte ordem: folhas, hastes, raízes e tubérculos-semente. Porém, com a formação dos tubérculos aos 34 DAP observou-se maior concentração de P neste órgão do que nas raízes. Os menores teores de $\mathrm{P}$ sempre foram observados nos tubérculos-semente. Na última avaliação o teor de $\mathrm{P}$ nas folhas foi superior aos observados nos demais órgãos das plantas. Tal como ocorreu para o $\mathrm{N}$, porém com certas variações, em todos os órgãos das plantas foram observados decréscimos na concentração de $\mathrm{P}$ no decorrer do ciclo. Gargantini et al. (1963) estudando a absorção de nutrientes pela cultivar Bintje, 
obtiveram teores de $\mathrm{P}$ nas hastes e folhas superiores ao observado no presente experimento, durante as fases iniciais do ciclo, porém, no final do ciclo os teores nestes órgãos foram inferiores aos aqui observados. Nos tubérculos, esses autores observaram teores de $\mathrm{P}$ superiores aos obtidos no presente estudo, em todas as avaliações. No entanto, os teores de P obtidos no presente estudo para as raízes, hastes e folhas foram superiores aos observados por Paula et al. (1986), nos referidos órgãos das cultivares Achat e Mantiqueira.

Tabela 10. Teor de P em cada parte das plantas de cultivares de batata durante o ciclo da cultura.

\begin{tabular}{|c|c|c|c|c|c|c|c|c|c|c|c|c|c|}
\hline \multirow{2}{*}{ Cultivares } & \multicolumn{13}{|c|}{ Dias após o plantio } \\
\hline & 0 & 20 & 27 & 34 & 41 & 48 & 55 & 62 & 69 & 76 & 83 & 90 & 97 \\
\hline & \multicolumn{13}{|c|}{$\begin{array}{l}\mathrm{g} \mathrm{kg}^{-1} \\
\text { Tubérculos-semente }\end{array}$} \\
\hline Ágata & 3,8 & 3,7 & 2,9 & 2,8 & 2,8 & 2,1 & 2,7 & 2,1 & - & - & - & - & - \\
\hline Asterix & 2,8 & 3,1 & 2,4 & 2,1 & 1,4 & 1,5 & 1,4 & 1,7 & - & - & - & - & - \\
\hline Atlantic & 2,3 & 2,4 & 2,1 & 2,0 & 2,6 & 1,8 & 1,8 & 1,9 & - & - & - & - & - \\
\hline Markies & 2,7 & 2,6 & 2,5 & 3,0 & 2,3 & 1,8 & 1,8 & 1,8 & - & - & - & - & - \\
\hline \multirow[t]{2}{*}{ Mondial } & 3,0 & 2,9 & 2,8 & 3,0 & 1,9 & 2,2 & 1,7 & 1,6 & - & - & - & - & - \\
\hline & \multicolumn{13}{|c|}{ Raízes } \\
\hline Ágata & - & 5,2 & 3,9 & 3,0 & 2,9 & 2,8 & 3,0 & 2,4 & 2,2 & 2,0 & 2,1 & 2,1 & 2,7 \\
\hline Asterix & - & 4,6 & 3,5 & 2,8 & 2,8 & 2,9 & 2,8 & 3,0 & 3,1 & 2,5 & 2,7 & 3,0 & 3,4 \\
\hline Atlantic & - & 4,9 & 4,1 & 2,8 & 3,0 & 3,0 & 2,7 & 2,8 & 2,7 & 2,2 & 2,0 & 2,5 & 2,5 \\
\hline Markies & - & 4,8 & 3,8 & 3,2 & 3,3 & 3,3 & 2,8 & 3,4 & 3,2 & 2,3 & 2,2 & 2,2 & 2,6 \\
\hline Mondial & - & 5,1 & 3,7 & 3,3 & 3,2 & 3,0 & 2,4 & 2,8 & 3,0 & 2,4 & 2,3 & 2,2 & 2,6 \\
\hline \multicolumn{14}{|c|}{ Hastes } \\
\hline Ágata & - & 5,6 & 4,2 & 3,8 & 3,6 & 3,6 & 2,1 & 2,4 & 1,9 & 1,4 & 1,4 & 1,7 & 1,9 \\
\hline Asterix & - & 5,0 & 4,2 & 4,2 & 4,2 & 4,7 & 3,7 & 4,8 & 4,3 & 3,0 & 2,1 & 2,5 & 2,2 \\
\hline Atlantic & - & 4,6 & 4,4 & 4,4 & 3,7 & 4,3 & 2,9 & 3,8 & 2,6 & 1,8 & 1,4 & 2,6 & 2,0 \\
\hline Markies & - & 4,7 & 4,8 & 4,4 & 4,4 & 4,6 & 3,3 & 3,8 & 2,6 & 1,8 & 1,4 & 2,7 & 2,7 \\
\hline Mondial & - & 4,8 & 4,6 & 4,5 & 3,9 & 4,5 & 4,2 & 4,5 & 3,6 & 2,7 & 2,5 & 3,1 & 2,9 \\
\hline & \multicolumn{13}{|c|}{ Folhas } \\
\hline Ágata & - & 7,7 & 6,2 & 5,0 & 5,1 & 4,4 & 3,7 & 3,1 & 3,0 & 2,7 & 2,0 & 2,0 & 2,6 \\
\hline Asterix & - & 8,5 & 5,4 & 4,8 & 4,7 & 4,4 & 3,5 & 3,7 & 3,8 & 3,3 & 2,7 & 2,0 & 2,9 \\
\hline Atlantic & - & 8,6 & 6,1 & 5,0 & 4,3 & 4,7 & 3,7 & 3,6 & 3,3 & 2,7 & 2,7 & 2,3 & 3,6 \\
\hline Markies & - & 9,1 & 6,3 & 5,5 & 5,0 & 4,4 & 3,7 & 3,7 & 3,2 & 2,6 & 2,3 & 2,2 & 3,3 \\
\hline Mondial & - & 8,6 & 6,0 & 5,9 & 5,1 & 5,1 & 5,1 & 4,2 & 4,1 & 3,4 & 2,9 & 3,0 & 3,5 \\
\hline & \multicolumn{13}{|c|}{ Tubérculos } \\
\hline Ágata & - & - & - & 5,3 & 4,0 & 4,1 & 3,2 & 2,9 & 3,5 & 3,0 & 2,9 & 2,7 & 2,6 \\
\hline Asterix & - & - & - & 4,0 & 3,5 & 3,7 & 3,0 & 2,4 & 2,6 & 2,6 & 2,5 & 2,4 & 2,8 \\
\hline Atlantic & - & - & - & 4,5 & 3,3 & 3,3 & 2,8 & 2,5 & 2,3 & 2,5 & 2,4 & 2,5 & 3,0 \\
\hline Markies & - & - & - & 5,4 & 4,3 & 4,4 & 4,2 & 3,5 & 3,6 & 3,3 & 2,9 & 2,7 & 2,3 \\
\hline Mondial & - & - & - & 5,5 & 3,7 & 3,6 & 3,9 & 4,1 & 3,4 & 3,3 & 2,8 & 2,6 & 2,6 \\
\hline
\end{tabular}


As maiores quantidades de $\mathrm{P}$ foram acumuladas nos tubérculos, seguido das folhas, hastes, tubérculos-semente e raízes (Figura 10).

Do momento do plantio até aos 62 DAP, houve redução do $\mathrm{P}$ total presente nos tubérculos-semente (Figura 10A). No plantio e aos 20 DAP, as cultivares Asterix e Ágata apresentaram as maiores quantidades de $\mathrm{P}$ nos tubérculos-semente, sendo que a partir dos 27 DAP, a redução mais acentuada do teor de $\mathrm{P}$ nos tubérculos-semente da cultivar Asterix refletiu em maiores decréscimos na quantidade de $\mathrm{P}$ nos tubérculos-semente dessa cultivar, em comparação à Ágata, aos 41 DAP (Tabela 10 e Figura 10A). As reduções observadas nas quantidades de $\mathrm{P}$ presente nos tubérculos-semente é reflexo da alta redistribuição do P pelo floema (MALAVOLTA, 1980), a qual ocorre em função da degradação de macromoléculas como ácidos nucléicos e fosfolipídeos, que permitem o reaproveitamento do P para o crescimento da planta (AERTS, 1996).

Nas raízes, os acúmulos de $\mathrm{P}$ aumentaram inicialmente atingindo os acúmulos máximos de 0,037, 0,074, 0,064, 0,056 e 0,047 $\mathrm{kg} \mathrm{ha}^{-1}$ aos 35, 38, 40, 56 e 63 DAP para as cultivares Ágata, Asterix, Atlantic, Markies e Mondial, respectivamente (Figura 10B). Da emergência até os 41 DAP, os maiores acúmulos de $\mathrm{P}$ ocorreram nas raízes das cultivares Asterix e Atlantic, sendo que a partir dos 48 DAP houve redução acentuada da quantidade P acumulada nas raízes dessas cultivares, ocasionando acúmulo semelhante ao obtido na cultivar Mondial. As cultivares Asterix e Ágata foram as mais precoces em acumular P em suas raízes, no entanto, durante todo o ciclo houve maior acúmulo de $\mathrm{P}$ nas raízes da cultivar Asterix em comparação à Ágata. As cultivares Markies e Mondial tiveram acúmulo inicial de $\mathrm{P}$ em suas raízes mais lento, atingindo, o ponto de máximo em torno de 21 e 25 dias após a cultivar Ágata (mais precoce) ter atingido o máximo acúmulo de P nas raízes. Yorinori (2003), observou acúmulo máximo de $\mathrm{P}$ nas raízes da cultivar Atlantic durante a safra das águas de $0,056 \mathrm{~kg} \mathrm{ha}^{-1}$ aos $61 \mathrm{DAP}$, ou seja, a quantidade acumulada foi inferior à observada e ocorreu mais no final do ciclo. 

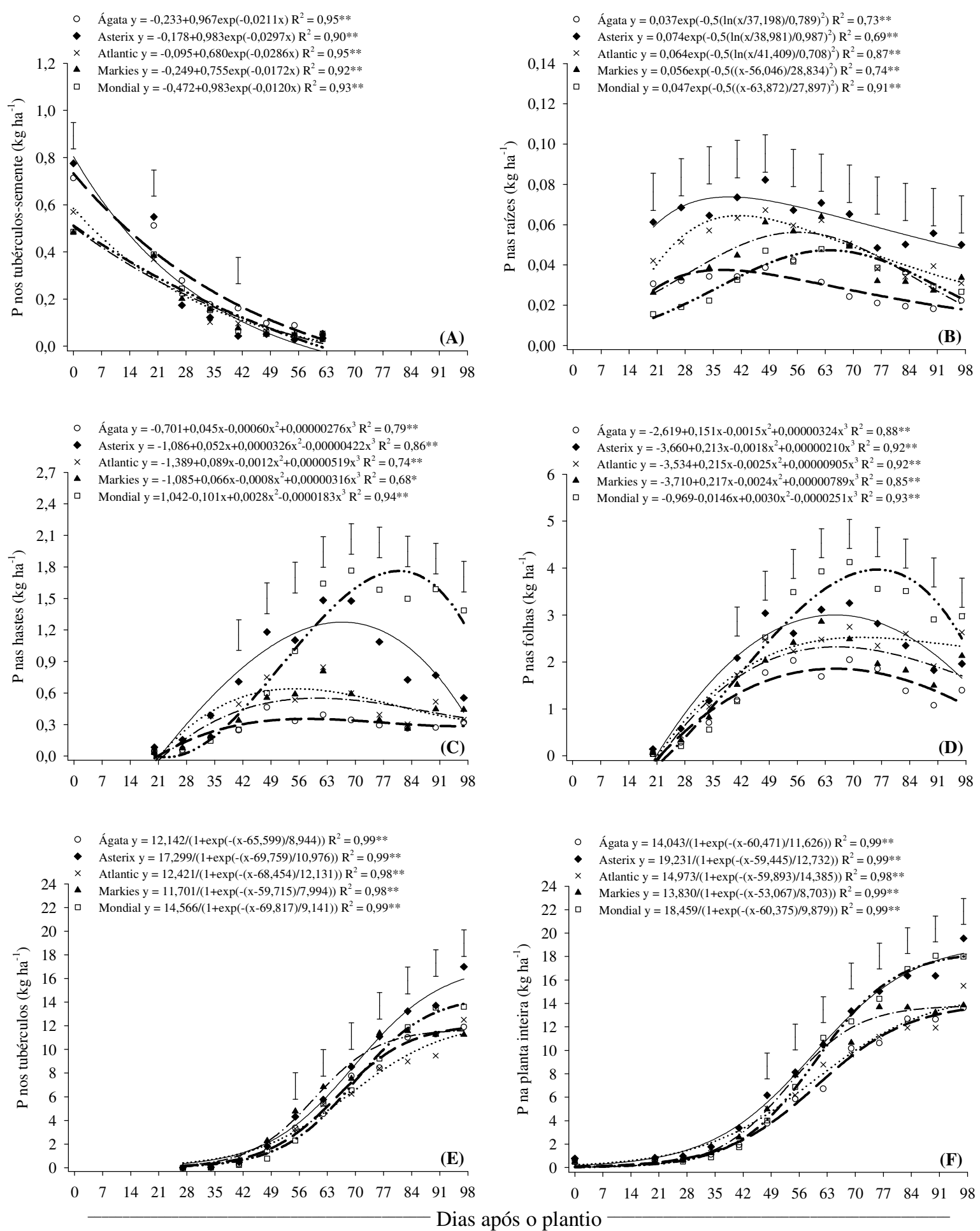

Figura 10. Quantidade de P nos tubérculos-semente (A), raízes (B), hastes (C), folhas (D), tubérculos $(\mathrm{E})$ e na planta inteira $(\mathrm{F})$ de cultivares de batata ao longo do ciclo. ** significativo a $1 \%$ de probabilidade pelo teste F. Barras verticais indicam o valor de DMS pelo teste Tukey a $5 \%$ de probabilidade. 
Os dados referentes ao acúmulo de $\mathrm{P}$ nas hastes ajustaram-se a modelos cúbicos de regressão (Figura 10C). Nota-se que as curvas são similares àquelas que descrevem a acumulação de MS, demonstrando acúmulo semelhante de $\mathrm{P}$ entre as cultivares até aos 34 DAP. A partir dos 41 DAP o acúmulo de $\mathrm{P}$ nas hastes aumentou em todas as cultivares, porém, com intensidades diferentes até atingir a quantidade máxima estimada de $0,35,1,27,0,64,0,55$ e 1,76 $\mathrm{kg} \mathrm{ha}^{-1}$ aos 58, 66, 55, 60 e 80 DAP para as cultivares Ágata, Asterix, Atlantic, Markies e Mondial, respectivamente. Entre 55 e 69 DAP, os maiores acúmulos de $\mathrm{P}$ foram observados nas hastes das cultivares Asterix e Mondial, mas, a partir dos 76 DAP houve redução na quantidade de $\mathrm{P}$ acumulada nas hastes da cultivar Asterix, enquanto as hastes da cultivar Mondial continuou acumulando $\mathrm{P}$ continuamente até aos 80 DAP, proporcionando assim, maiores acúmulos de $\mathrm{P}$ nas hastes da cultivar Mondial no final do ciclo. Os maiores acúmulos de $\mathrm{P}$ observados nas cultivares Mondial e Asterix após os 55 DAP, é resultado do maior acúmulo de MS nas hastes dessas cultivares (Figura 5C).

Os acúmulos de $\mathrm{P}$ nas folhas não diferiram entre as cultivares até aos 34 DAP, coincidindo com o período de menor acúmulo de MS (Figura 10D). A partir dos 41 DAP os acúmulos de $\mathrm{P}$ nas folhas intensificaram-se alcançando os máximos estimados de 1,8; 3,0; 2,5; 2,3 e 3,9 $\mathrm{kg} \mathrm{ha}^{-1}$ aos 65, 65, 71, 65 e 76 DAP nas cultivares Ágata, Asterix, Atlantic, Markies e Mondial, respectivamente. Os maiores acúmulos de $\mathrm{P}$ nas folhas foram observados na cultivar Mondial entre 55 e 90 DAP, enquanto que os menores acúmulos durante esse período foram observados na cultivar Ágata. Na ultima avaliação, Atlantic e Mondial obtiveram acúmulo semelhante de P nas folhas e superior aos obtidos em Ágata e Asterix.

Os dados referentes ao acúmulo de $\mathrm{P}$ nos tubérculos foram ajustados a modelos sigmóides de regressão (Figura 10E). Os tubérculos acumularam P continuamente do início da tuberização até o final do ciclo, atingindo no final, os acúmulos máximos estimados de 12, 16, 11, 12 e $14 \mathrm{~kg} \mathrm{ha}^{-1}$ pelas cultivares Ágata, Asterix, Atlantic, Markies e Mondial, respectivamente. Entre 34 DAP e 48 DAP, houve acúmulo semelhante de $\mathrm{P}$ entre todas as cultivares estudadas, porém, durante a fase enchimento dos tubérculos (42 a 90 DAP), houve aumento gradual e diferente da quantidade acumulada de $\mathrm{P}$ nos tubérculos de todas as cultivares, com as taxas máximas de acúmulo atingindo os valores máximos de 0,34, 0,39, 0,25, 0,36 e 0,39 $\mathrm{kg} \mathrm{ha}^{-1} \mathrm{dia}^{-1}$ aos 65, 69, 69, 59 e $69 \mathrm{DAP}$, respectivamente, para as cultivares Ágata, Asterix, Atlantic, Markies e Mondial (Figura 11A e Tabela 11). 
No início da fase de enchimento de tubérculos a cultivar Markies apresentou maior acúmulo de $\mathrm{P}$ em seus tubérculos, quando comparada à Mondial e Ágata. $\mathrm{O}$ maior acúmulo de $\mathrm{P}$ apresentado pela cultivar Markies nessa época é resultado do aumento precoce das taxas de acúmulo de $\mathrm{P}$ nos tubérculos dessa cultivar (Figura 11A). No final do ciclo, os maiores acúmulos de $\mathrm{P}$ nos tubérculos foram observados na cultivar Asterix, enquanto nas cultivares Mondial, Atlantic e Ágata o acúmulo de P foi semelhante e inferiores ao da Asterix. Os tubérculos da culivar Asterix acumularam mais $\mathrm{P}$ em comparação às demais cultivares devido ao maior acúmulo de MS (Figura 5E) uma vez que o teor de $\mathrm{P}$ nos tubérculos dessas cultivares foram bem próximos (Tabela 10). Já os acúmulos semelhantes de P nos tubérculos das cultivares Atlantic e Markies na última avaliação, sem dúvida ocorreram devido aos maiores teores de $\mathrm{P}$ obtidos nos tubérculos da cultivar Atlantic em comparação à Markies, (Tabela 10), uma vez que, o acúmulo de MS em ambas cultivares apresentou diferença significativa (Figura 5E).

Após a tuberização, os tubérculos tornaram-se os drenos principais das plantas, chegando a representar no final do ciclo entre $85,7 \%$ e $88,8 \%$ do total de $\mathrm{P}$ absorvido pelas plantas das cultivares Markies e Asterix e, entre 75,0\% e 78,5\% nas cultivares Ágata, Mondial e Atlantic (Figura 10E). Esses dados estão de acordo com os obtidos por Paula et al. (1986), em estudo sobre a produção de MS e absorção de macronutrientes pela batateira, cultivar Mantiqueira, na qual constatou-se que os tubérculos acumularam em torno de $88 \%$ da quantidade extraída. 

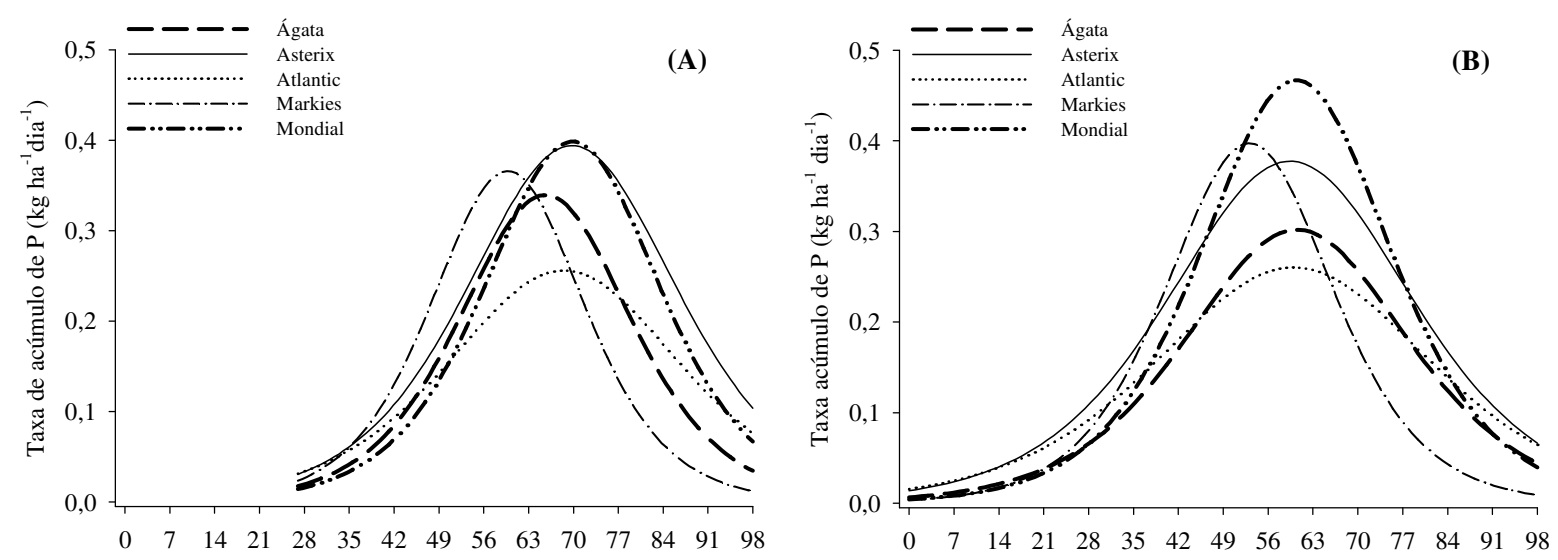

Dias após o plantio

Figura 11. Taxa de acúmulo de $\mathrm{P}$ nos tubérculos (A) e nas plantas (B) de cultivares de batata ao longo do ciclo.

Tabela 11. Quantidade máxima de $\mathrm{P}$ acumulada, taxa diária máxima de acúmulo e época de maior taxa de acúmulo de $\mathrm{P}$ nos tubérculos e nas plantas de cultivares de batata.

\begin{tabular}{lcccccc}
\hline Cultivares & $\begin{array}{c}\text { Acúmulo } \\
\text { máximo no } \\
\text { tubérculo }\end{array}$ & $\begin{array}{c}\text { Taxa } \\
\text { máxima de } \\
\text { acúmulo no } \\
\text { tubérculo }\end{array}$ & $\begin{array}{c}\text { Época de } \\
\text { maior taxa de } \\
\text { acúmulo no } \\
\text { tubérculo }\end{array}$ & $\begin{array}{c}\text { Acúmulo } \\
\text { máximo na } \\
\text { planta }\end{array}$ & $\begin{array}{c}\text { Taxa } \\
\text { máxima de } \\
\text { acúmulo na } \\
\text { planta }\end{array}$ & $\begin{array}{c}\text { Época de } \\
\text { maior taxa } \\
\text { de acúmulo } \\
\text { na planta }\end{array}$ \\
\hline Ágata & $\mathrm{kg} \mathrm{ha}^{-1}$ & $\mathrm{~kg} \mathrm{ha}^{-1} \mathrm{dia}^{-1}$ & $\begin{array}{c}\mathrm{DAP} \\
\mathrm{kg} \mathrm{ha}^{-1}\end{array}$ & $\mathrm{~kg} \mathrm{ha}^{-1} \mathrm{dia}^{-1}$ & $\mathrm{DAP}$ \\
Asterix & 12 & 0,34 & 65 & 14 & 0,30 & 60 \\
Atlantic & 16 & 0,39 & 69 & 18 & 0,38 & 59 \\
Markies & 11 & 0,25 & 69 & 14 & 0,26 & 59 \\
Mondial & 12 & 0,36 & 59 & 14 & 0,39 & 53 \\
\hline
\end{tabular}

As quantidades de $\mathrm{P}$ acumuladas pelas plantas das cultivares de batata apresentaram ajustes a modelos sigmóides de regressão (Figura 10F). Os valores foram semelhantes entre as cultivares, nos primeiros 41 DAP, coincidindo com o período de menor acúmulo de MS (Figura 10F e Tabela 11). Durante a fase de crescimento vegetativo houve pequena absorção de $\mathrm{P}$ uma vez que as taxas diárias de absorção foram baixas e as cultivares que absorveram maior proporção do $\mathrm{P}$ nesse período extraíram menos de $16 \%$ da quantidade total absorvida (Figura 11B e Tabela 12). Durante todo o estádio de enchimento de tubérculos (42 a 90 DAP) foram absorvidos entre $73 \%$ (Atlantic) e $85 \%$ (Mondial) do total de P. No entanto, no início desse estádio (42 a 62 DAP), as cultivares Markies e Mondial absorveram 
cerca de $54 \%$ e $43 \%$ da quantidade total extraída (Tabela 12). A maior proporção da absorção apresentada por essas duas cultivares nesse período deve-se a ocorrência precoce das maiores taxas de absorção na cultivar Markies, bem com pelas altas taxas diárias de absorção obtidas na cultivar Mondial (Figura 11B e Tabela 11). No final do ciclo, os maiores acúmulos foram de $18 \mathrm{~kg} \mathrm{ha}^{-1}$, em ambas as cultivares Asterix e Mondial, enquanto, os menores acúmulos foram $14 \mathrm{~kg} \mathrm{ha}^{-1}$ obtidos nas cultivares Ágata, Atlantic e Markies (Figura 10F e Tabela 11). O maior acúmulo de P pelas cultivares Asterix e Mondial se explica pelo maior acúmulo de MS apresentado por essas cultivares nessa época (Figura 5F). Em todas as avaliações após os 48 DAP, a cultivar Asterix apresentou maiores acúmulos de $\mathrm{P}$ em relação à Ágata, o que está relacionado com a maior quantidade de MS e as maiores taxas de absorção de $\mathrm{P}$ apresentadas por Asterix em comparação à Ágata (Figura 5F e Figura 11). Yorinori (2003) em estudo sobre o crescimento e o acúmulo de nutrientes pela batateira, cultivar Atlantic, observou acúmulos totais de $\mathrm{P}$ superiores ao obtido pela cultivar Atlantic no presente estudo. No entanto, este autor trabalhou com população de plantas maior (41.667 plantas $\left.\mathrm{ha}^{-1}\right)$ e obteve produtividades (36.500 $\mathrm{kg} \mathrm{ha}^{-1}$ na safra das águas e $24.000 \mathrm{~kg} \mathrm{ha}^{-1}$ na safra das secas) maiores do que as do presente experimento.

A época de maior taxa de absorção de $\mathrm{P}$ foi dos $34 \mathrm{DAP}$ até em torno dos 53 a 60 DAP quando as taxas diárias de absorção atingiram o ponto máximo (Figura 11 e Tabela 11), no entanto, no período compreendido entre 59 e 69 DAP, quando as taxas de absorção de $\mathrm{P}$ já tinham diminuído, ocorreram as maiores taxas diárias de acúmulo de $\mathrm{P}$ nos tubérculos, indicando que em média, 7 dias após a ocorrência das máximas taxas diárias de absorção, têm-se o período de maior translocação do $\mathrm{P}$ das demais partes da planta para os tubérculos. Nota-se que as taxas máximas diárias de absorção de $\mathrm{P}$ foram semelhantes ou até inferiores às taxas máximas de acúmulo de $\mathrm{P}$ nos tubérculos, demonstrando que o $\mathrm{P}$, sofre intensa translocação para os tubérculos, o que está de acordo com relatos de Malavolta (1980) de que o $\mathrm{P}$ apresenta alta redistribuição pelo floema.

Estudos realizados por Yorinori (2003) demonstraram que as maiores taxas de absorção de $\mathrm{P}$ pela cultivar Atlantic, foram de $0,60 \mathrm{~kg} \mathrm{ha}^{-1} \mathrm{dia}^{-1}$ e ocorreram entre os 63 e 69 DAP, ou seja, foram superiores e ocorreram em média 10 dias após as maiores taxas de absorção desse elemento. 
As cultivares apresentaram pico de maior absorção de $\mathrm{P}$ entre os 53 e 60 DAP, período em que também ocorreram as maiores taxas de absorção de N (Figura 9B e Tabela 8), demonstrando, que a época preferencial de absorção de ambos os nutrientes ocorre durante a fase de enchimento de tubérculos. No entanto, o aumento na taxa diária de absorção de $\mathrm{P}$ durante a fase de enchimento de tubérculos é pequeno alcançando o valor máximo de $0,46 \mathrm{~kg} \mathrm{ha}^{-1} \mathrm{dia}^{-1}$. Esses resultados confirmam os obtidos por Gargantini et al. (1963) e Fontes (1997b) de que o P é absorvido continuamente pela batateira do início ao final do ciclo.

Tabela 12. Percentual de $\mathrm{P}$ acumulado pelas plantas em cada fase do desenvolvimento das cultivares de batata (valores obtidos nas equações ajustadas).

\begin{tabular}{|c|c|c|c|c|c|}
\hline \multirow{3}{*}{ Cultivares } & \multicolumn{5}{|c|}{ Dias após o plantio/Fase da cultura } \\
\hline & $0-34$ & $35-41$ & $42-62$ & $63-90$ & $91-97$ \\
\hline & Crescimento vegetativo & Tuberização & Enchiment & abérculos & Maturação \\
\hline Ágata & 10 & 7 & 39 & 41 & 3 \\
\hline Asterix & 13 & 7 & 38 & 39 & 3 \\
\hline Atlantic & 16 & 7 & 35 & 38 & 4 \\
\hline Markies & 10 & 10 & 54 & 25 & 1 \\
\hline Mondial & 7 & 6 & 43 & 42 & 2 \\
\hline
\end{tabular}

\subsubsection{Potássio}

Inicialmente houve aumento nos teores de $\mathrm{K}$ dos tubérculos-sementes, porém, com reduções nas últimas avaliações (Tabela 13). Nas hastes, folhas e tubérculos, houve aumentos no teor de $\mathrm{K}$ até aos $48 \mathrm{DAP}$, os quais atingiram em média 131, 99 e $49 \mathrm{~g} \mathrm{~kg}$ 1, respectivamente, com posterior diminuição até o final do ciclo. Nas raízes os teores diminuíram desde a emergência até aos 90 DAP. Entre os órgãos das plantas, os maiores teores de $\mathrm{K}$ durante todo o ciclo foram encontrados nas hastes e folhas, enquanto que os menores teores foram observados nos tubérculos. Gargantini et al. (1963) também relatam que os maiores teores de $\mathrm{K}$ ocorreram nas hastes e folhas da batateira, os quais chegaram a atingir valores de 127 e $68 \mathrm{~g} \mathrm{~kg}^{-1}$ de $\mathrm{K}$, respectivamente, quando as plantas estavam com dez dias de emergidas. Paula et al. (1986) também observaram os maiores teores de $\mathrm{K}$ ocorrendo nas hastes e folhas das cultivares Achat e Mantiqueira. Porém, os teores observados por estes 
autores foram inferiores aos obtidos no presente experimento e aos relatados por Gargantini et al. (1963).

Os maiores acúmulos de $\mathrm{K}$, entre os órgãos das plantas, obedeceram a mesma seqüência observada para $\mathrm{N}$ e $\mathrm{P}$, sendo as maiores quantidades encontradas nos tubérculos, seguido das folhas, hastes, tubérculos-semente e raízes (Figura 12).

As quantidades de $\mathrm{K}$ presentes nos tubérculos-semente foram ajustadas a modelos lineares de regressão (Figura 12A). O K dos tubérculos-semente diminuiu em todas as cultivares de maneira linear a partir do plantio até a última coleta em que foi possível encontrar tubérculos-semente (Figura 12A). A cultivar Atlantic apresentou quantidades de K nos tubérculos-semente superiores às observadas na cultivar Mondial, durante todo período de avaliação. As diferenças observadas entre as cultivares quanto às quantidades de $\mathrm{K}$ presente nos tubérculos-semente a partir dos 27 DAP estão muito mais relacionadas com variações no teor de $\mathrm{K}$ dos tubérculos-semente do que a alteração nas quantidades de MS contidas neste órgão, uma vez que esta não diferiu entre as cultivares durante o período em questão (Tabela 13 e Figura 5A).

Os acúmulos de $\mathrm{K}$ nas raízes aumentaram inicialmente alcançando os valores máximos acumulados de $0,73,1,24,1,04,0,71$ e $0,56 \mathrm{~kg} \mathrm{ha}^{-1}$ aos $38,35,40,44,56$ DAP, respectivamente, para as cultivares Ágata, Asterix, Atlantic, Markies, e Mondial (Figura 12B). De maneira geral, os maiores acúmulos de K ocorreram nas raízes das cultivares Asterix e Atlantic da emergência até os 41 DAP. Após os 41 DAP, houve redução no acúmulo de $\mathrm{K}$ nas raízes das cultivares Asterix, Atlantic e Ágata, enquanto o acúmulo de $\mathrm{K}$ nas raízes da cultivar Mondial permaneceu crescente até próximo aos 56 DAP, mantendo-se relativamente constante até o final do ciclo. O maior acúmulo de $\mathrm{K}$ nas raízes da cultivar Mondial na fase final do ciclo, associado com as reduções das quantidades acumuladas de $\mathrm{K}$ observadas nas raízes das demais cultivares, refletiu em acúmulos semelhantes de $\mathrm{K}$ nas raízes de todas as cultivares nas últimas avaliações. Yorinori (2003) observou acúmulo máximo de K nas raízes da cultivar Atlantic de $0,39 \mathrm{~kg} \mathrm{ha}^{-1}$ na safra das águas (68 DAP) e $0,72 \mathrm{~kg} \mathrm{ha}^{-1}$ na safra das secas (32 DAP), ou seja, inferiores aos observados no presente experimento para a mesma cultivar. 
Tabela 13. Teor de $\mathrm{K}$ em cada parte das plantas de cultivares de batata durante o ciclo da cultura.

\begin{tabular}{|c|c|c|c|c|c|c|c|c|c|c|c|c|c|}
\hline \multirow{2}{*}{ Cultivares } & \multicolumn{13}{|c|}{ Dias após o plantio } \\
\hline & 0 & 20 & 27 & 34 & 41 & 48 & 55 & 62 & 69 & 76 & 83 & 90 & 97 \\
\hline $\begin{array}{l}\mathrm{g} \mathrm{kg}^{-1} \\
\text { Tubérculos-semente }\end{array}$ & \multicolumn{13}{|c|}{$\mathrm{g} \mathrm{kg}^{-1}$} \\
\hline Ágata & 42 & 47 & 51 & 67 & 74 & 79 & 66 & 39 & - & - & - & - & - \\
\hline Asterix & 31 & 42 & 61 & 82 & 93 & 85 & 47 & 27 & - & - & - & - & - \\
\hline Atlantic & 34 & 43 & 56 & 91 & 94 & 108 & 96 & 99 & - & - & - & - & - \\
\hline Markies & 39 & 43 & 56 & 79 & 96 & 105 & 97 & 63 & - & - & - & - & - \\
\hline Mondial & 35 & 35 & 41 & 48 & 64 & 59 & 56 & 52 & - & - & - & - & - \\
\hline \multicolumn{14}{|c|}{ Raízes } \\
\hline Ágata & - & 73 & 66 & 67 & 68 & 55 & 37 & 35 & 37 & 43 & 37 & 36 & 42 \\
\hline Asterix & - & 61 & 58 & 56 & 50 & 45 & 35 & 29 & 35 & 37 & 27 & 33 & 46 \\
\hline Atlantic & - & 67 & 55 & 53 & 55 & 49 & 37 & 28 & 33 & 37 & 31 & 26 & 36 \\
\hline Markies & - & 60 & 54 & 50 & 54 & 47 & 32 & 29 & 32 & 26 & 25 & 28 & 43 \\
\hline Mondial & - & 58 & 53 & 56 & 52 & 45 & 31 & 27 & 30 & 34 & 27 & 36 & 42 \\
\hline \multicolumn{14}{|c|}{ Hastes } \\
\hline Ágata & - & 75 & 109 & 128 & 126 & 130 & 111 & 107 & 100 & 104 & 93 & 94 & 102 \\
\hline Asterix & - & 79 & 119 & 136 & 138 & 137 & 124 & 118 & 109 & 111 & 92 & 102 & 107 \\
\hline Atlantic & - & 87 & 105 & 125 & 121 & 126 & 104 & 106 & 98 & 96 & 80 & 86 & 79 \\
\hline Markies & - & 67 & 98 & 115 & 112 & 126 & 110 & 101 & 98 & 100 & 83 & 94 & 89 \\
\hline Mondial & - & 64 & 102 & 121 & 118 & 135 & 120 & 97 & 105 & 102 & 98 & 98 & 107 \\
\hline \multicolumn{14}{|c|}{ Folhas } \\
\hline Ágata & - & 69 & 76 & 83 & 96 & 91 & 83 & 88 & 93 & 89 & 85 & 76 & 53 \\
\hline Asterix & - & 61 & 68 & 84 & 91 & 95 & 82 & 82 & 89 & 85 & 82 & 85 & 77 \\
\hline Atlantic & - & 71 & 85 & 88 & 99 & 106 & 88 & 96 & 95 & 91 & 86 & 76 & 72 \\
\hline Markies & - & 60 & 74 & 77 & 79 & 99 & 79 & 86 & 91 & 90 & 85 & 68 & 60 \\
\hline Mondial & - & 64 & 77 & 86 & 86 & 102 & 92 & 87 & 92 & 84 & 81 & 68 & 60 \\
\hline \multicolumn{14}{|c|}{ Tubérculos } \\
\hline Ágata & - & - & - & 48 & 49 & 50 & 38 & 32 & 38 & 36 & 25 & 24 & 22 \\
\hline Asterix & - & - & - & 41 & 48 & 50 & 34 & 28 & 32 & 31 & 24 & 24 & 19 \\
\hline Atlantic & - & - & - & 44 & 47 & 43 & 30 & 31 & 30 & 33 & 23 & 24 & 23 \\
\hline Markies & - & - & - & 50 & 53 & 51 & 38 & 35 & 37 & 35 & 26 & 26 & 25 \\
\hline Mondial & - & - & - & 56 & 52 & 49 & 40 & 36 & 35 & 35 & 34 & 25 & 21 \\
\hline
\end{tabular}



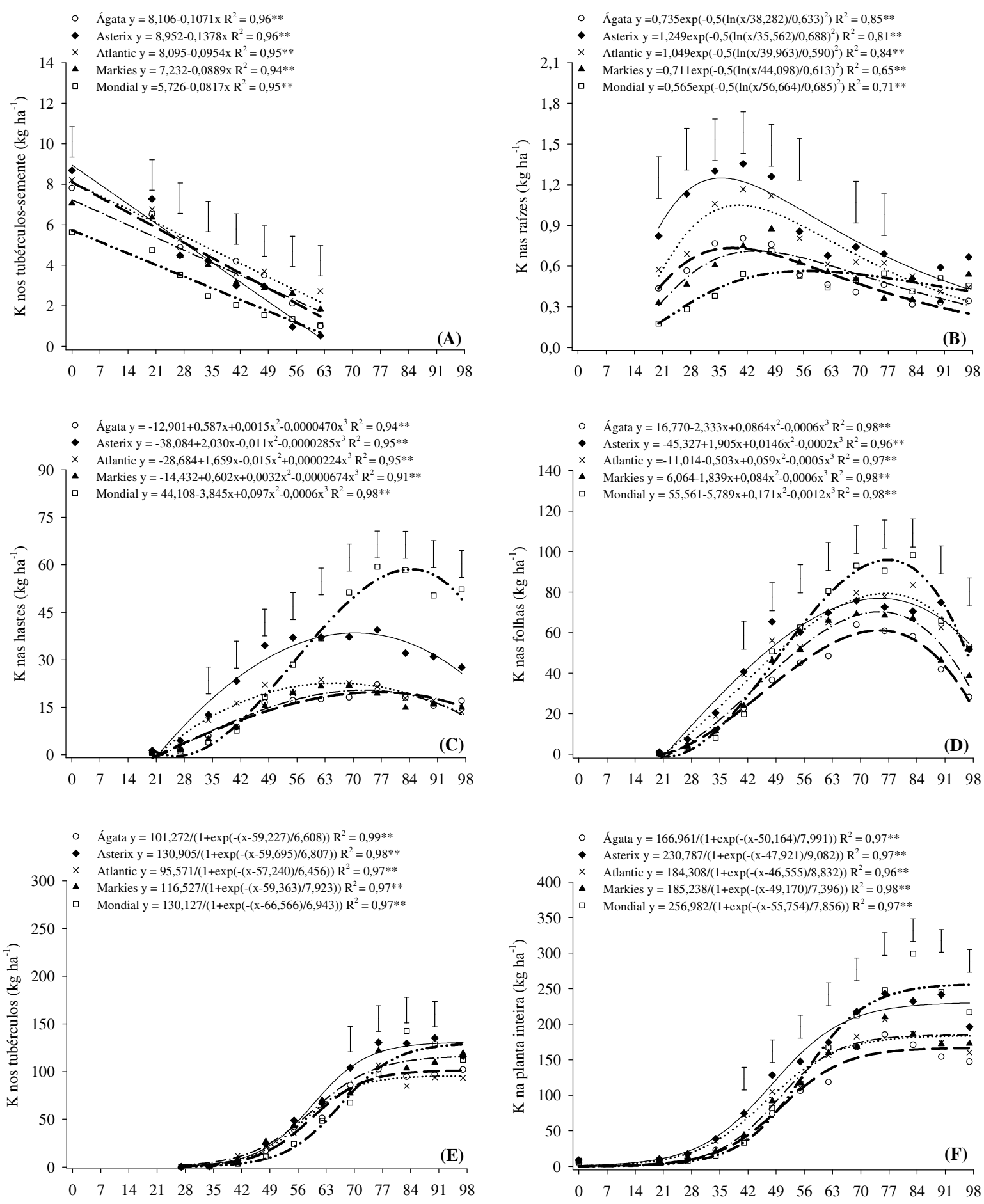

Dias após o plantio

Figura 12. Quantidade de K nos tubérculos-semente (A), raízes (B), hastes (C), folhas (D), tubérculos $(\mathrm{E})$ e na planta inteira $(\mathrm{F})$ de cultivares de batata ao longo do ciclo. $* *$ significativo a $1 \%$ de probabilidade pelo teste F. Barras verticais indicam o valor de DMS pelo teste Tukey a $5 \%$ de probabilidade. 
Nas hastes, as quantidades de $\mathrm{K}$ acumuladas apresentaram ajustes a modelos cúbicos de regressão (Figura 12C). As hastes de todas as cultivares estudadas não apresentaram diferenças significativas quanto ao acúmulo de $\mathrm{K}$ até aos 27 DAP e, a partir dos 35 DAP, a quantidade de $\mathrm{K}$ acumulada pelas hastes aumentou, com intensidades diferentes entre as cultivares. As quantidades máximas de $\mathrm{K}$ acumuladas nas hastes foram estimadas em $19,7,38,5,22,6,20,4$ e 58,5 $\mathrm{kg} \mathrm{ha}^{-1}$ aos 76, 70, 65, 72 e 84 DAP, respectivamente, para as cultivares Ágata, Asterix, Atlantic, Markies e Mondial. No período de 34 a 55 DAP, a cultivar Asterix apresentou acúmulo intenso de $\mathrm{K}$ em suas hastes e superior ao observado na cultivar Mondial, no entanto, a partir dos 70 DAP houve redução na quantidade de K acumulada nas hastes da cultivar Asterix, enquanto as hastes da cultivar Mondial apresentaram comportamento de acúmulo crescente de $\mathrm{K}$ até aos 84 DAP, refletindo assim, em maiores acúmulos de $\mathrm{K}$ nas hastes dessa cultivar no final do ciclo. Os maiores acúmulos de $\mathrm{K}$ observados nas hastes das cultivares Mondial e Asterix após os 55 DAP, é reflexo do maior acúmulo de MS nas hastes dessas cultivares (Figura 5C).

Os dados referentes ao acúmulo de $\mathrm{K}$ nas folhas sofreram ajustes a modelos cúbicos de regressão (Figura 12D). O acúmulo de $\mathrm{K}$ nas folhas não diferiu entre as cultivares até aos 34 DAP. No período entre 48 e 62 DAP, apenas a cultivar Mondial foi superior a cultivar Ágata em acumular K em suas folhas, no entanto, dos 69 DAP até o final do ciclo, tanto Mondial como Atlantic apresentaram acúmulo de $\mathrm{K}$ nas folhas superior ao obtido na cultivar Ágata. Os valores máximos estimados de 61,0, 76,8, 79,3, 70,2 e 95,8 kg ha1, foram alcançados aos 74, 74, 76, 75 e 76 DAP, nas cultivares Ágata, Asterix, Atlantic, Markies e Mondial, respectivamente. Nas últimas avaliações, as diminuições das quantidades e K acumuladas nas raízes e hastes (Figuras 12B e 12C) estão mais relacionadas com a redução da MS, enquanto, nas folhas além da redução da MS (Figura 5D) proporcionada pela queda de folhas (Figura 3B), nota-se, que houve remobilização do $\mathrm{K}$ das folhas para outras partes das plantas, uma fez que os teores foram decrescentes nesse período (Tabela 13).

Os acúmulos de $\mathrm{K}$ nos tubérculos de todas as cultivares foram ajustados a modelos sigmóides de regressão (Figura 12E). Os tubérculos acumularam K do início da tuberização até próximo aos 83 e 90 DAP, alcançando os acúmulos máximos estimados de 101, 130, 95, 115 e $128 \mathrm{~kg} \mathrm{ha}^{-1}$, respectivamente, pelas cultivares Ágata, Asterix, Atlantic, Markies e Mondial. Do total de K extraído, as cultivares Mondial, Atlantic e Asterix 
acumularam entre 50,0\% e 56,5\% do K em seus tubérculos, enquanto que nas cultivares Ágata e Markies essa proporção foi maior e ficou em torno de $60,8 \%$ e $62,1 \%$, respectivamente (Figura 12E). Paula et al. (1986) observaram maiores proporções de acúmulo de K nos tubérculos da cultivar Mantiqueira, as quais permaneceram em torno de $67 \%$ e $80 \%$, sob condição não adubada e adubada com NPK, respectivamente. No período compreendido entre 69 e 76 DAP, o acúmulo de K nos tubérculos da cultivar Asterix foi superior ao obtido na cultivar Mondial, o que é reflexo do maior acúmulo de MS obtido na cultivar Asterix (Figura 5F). Entre 83 e 90 DAP, o acúmulo de K nos tubérculos da cultivar Mondial foi semelhante ao observado na cultivar Asterix, sendo que, em ambas o acúmulo de $\mathrm{K}$ foi superior ao das cultivares Ágata e Atlantic. Na última avaliação o acúmulo de K foi semelhante entre todas as cultivares, provavelmente, devido aos maiores teores observados nos tubérculos das cultivares Atlantic e Markies (Tabela 13).

Embora tenha ocorrido acúmulo de K durante todo o ciclo, no período entre 57 e 66 DAP, observou-se o pico de maior acúmulo diário de K nos tubérculos, quando as cultivares Ágata, Asterix, Atlantic, Markies e Mondial acumularam em torno de 3,83, 4,80, 3,69, 3,67 e 4,68 $\mathrm{kg} \mathrm{ha}^{-1} \mathrm{dia}^{-1}$, respectivamente (Figura 13A e Tabela 14).
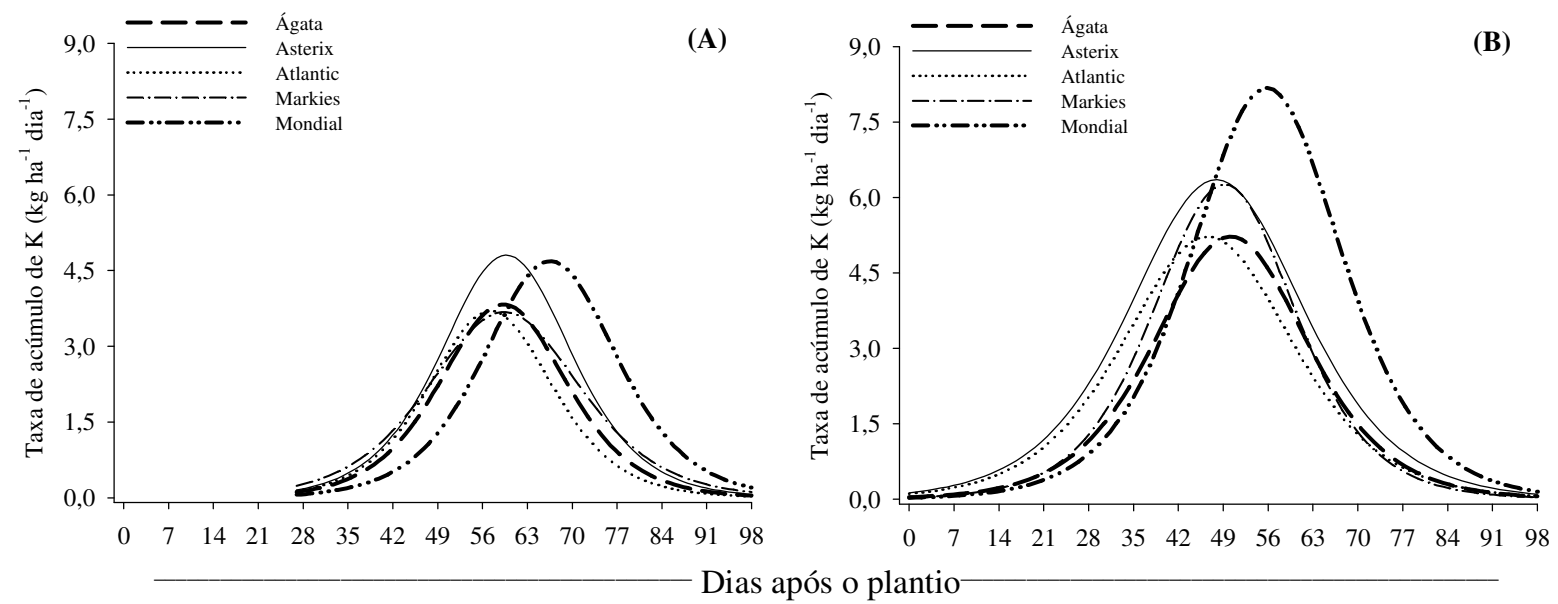

Figura 13. Taxa de acúmulo de $\mathrm{K}$ nos tubérculos (A) e nas plantas (B) de cultivares de batata ao longo do ciclo. 
Tabela 14. Quantidade máxima de K acumulada, taxa diária máxima de acúmulo e época de maior taxa de acúmulo de $\mathrm{K}$ nos tubérculos e nas plantas de cultivares de batata.

\begin{tabular}{lcccccc}
\hline Cultivares & $\begin{array}{c}\text { Acúmulo } \\
\text { máximo no } \\
\text { tubérculo }\end{array}$ & $\begin{array}{c}\text { Taxa } \\
\text { máxima de } \\
\text { acúmulo no } \\
\text { tubérculo }\end{array}$ & $\begin{array}{c}\text { Época de } \\
\text { maior taxa } \\
\text { de acúmulo } \\
\text { no tubérculo }\end{array}$ & $\begin{array}{c}\text { Acúmulo } \\
\text { máximo na } \\
\text { planta }\end{array}$ & $\begin{array}{c}\text { Taxa } \\
\text { máxima de } \\
\text { acúmulo na } \\
\text { planta }\end{array}$ & $\begin{array}{c}\text { Época de } \\
\text { maior taxa de } \\
\text { acúmulo na } \\
\text { planta }\end{array}$ \\
\hline Ágata & $\mathrm{kg} \mathrm{ha}^{-1}$ & $\mathrm{~kg} \mathrm{ha}^{-1} \mathrm{dia}^{-1}$ & DAP & $\mathrm{kg} \mathrm{ha}^{-1}$ & ${\mathrm{~kg} \mathrm{ha} \mathrm{dia}^{-1}}^{-1}$ & $\mathrm{DAP}$ \\
Asterix & 101 & 3,83 & 59 & 166 & 5,22 & 50 \\
Atlantic & 130 & 4,80 & 59 & 230 & 6,35 & 48 \\
Markies & 95 & 3,69 & 57 & 184 & 5,21 & 47 \\
Mondial & 115 & 3,67 & 59 & 185 & 6,26 & 49 \\
\hline
\end{tabular}

Os dados referentes aos acúmulos de $\mathrm{K}$ nas plantas inteiras foram ajustados a modelos sigmóides de regressão (Figura 12F). Nos primeiros 34 DAP o acúmulo de $\mathrm{K}$ em todas as cultivares foi lento, sendo que nesse período, a cultivar Mondial absorveu apenas $6 \%$ de todo o $\mathrm{K}$ acumulado durante o ciclo, enquanto, as cultivares Asterix e Atlantic, absorveram em torno de $18 \%$ e $20 \%$, respectivamente (Figura 12F e Tabela 15). A menor porcentagem de absorção observada na cultivar Mondial nas fases iniciais é explicada pelas baixas taxas diárias de absorção de $\mathrm{K}$, as quais, embora crescentes foram inferiores às observadas nas cultivares Asterix e Atlantic durante esse período (Figura 13 B). No estádio de enchimento de tubérculos (42 a 90 DAP) o acúmulo de K intensificou-se de maneira diferente entre as cultivares, sendo absorvido nesse período $86 \%, 76 \%, 75 \%, 67 \%$ e $65 \%$ da quantidade total de $\mathrm{K}$ extraída pelas cultivares Mondial, Ágata, Markies, Asterix e Atlantic, respectivamente (Figura 12F e Tabela 15). No entanto, durante o início dessa fase, ou seja, dos 42 aos 62 DAP, as cultivares Markies e Ágata absorveram em torno de $61 \%$ e $58 \%$ da quantidade total de $\mathrm{K}$ acumulada, enquanto, as cultivares Mondial, Asterix e Atlantic absorveram cerca de $56 \%, 51 \%$ e $51 \%$ da quantidade total (Tabela 15). Esses dados demonstram que, embora as cultivares Atlantic e Asterix tenham apresentado absorção mais precoce de K, durante a fase de crescimento vegetativo, e as cultivares Markies e Ágata durante o início da fase de enchimento de tubérculos, de maneira geral, a maior absorção desse elemento ocorre durante a toda a fase de enchimento dos tubérculos.

No período entre 76 e 90 DAP, os maiores acúmulos de K ocorreram nas cultivares Asterix e Mondial, o que é reflexo dos maiores acúmulos de MS e das maiores taxas de absorção, apresentadas por essas cultivares durante o ciclo (Figura 5F e 13B). Embora 
não tenha se observado diferenças significativas entre a quantidade de $\mathrm{K}$ acumulada pelas plantas das cultivares Asterix e Markies na última avaliação, dos 69 DAP até o final do ciclo, os menores acúmulos de $\mathrm{K}$ ocorreram nas cultivares Markies, Ágata e Atlantic. Yorinori (2003) em estudo sobre o crescimento e o acúmulo de nutrientes pela batateira, cultivar Atlantic, obteve acúmulos totais de $\mathrm{K}$ de $133,8 \mathrm{~kg} \mathrm{ha}^{-1}$ (safra das águas) e 139,1 kg ha-1 (safra das secas) aos 93 e 72 DAP, respectivamente, os quais foram inferiores ao observado no presente experimento.

Em torno de 47 e 55 DAP quando as taxas diárias de absorção atingiram o ponto máximo, notou-se a época de maior taxa de absorção de $\mathrm{K}$, porém, no período compreendido entre 57 e 66 DAP, quando as taxas diárias de absorção de K já estavam diminuindo, ocorreram as maiores taxas diárias de acúmulo de $\mathrm{K}$ nos tubérculos, indicando que em média, 10 dias após a ocorrência das máximas taxas diárias de absorção de $\mathrm{K}$, têm-se o período de maior translocação desse elemento para os tubérculos (Figura 13 e Tabela 14). Isso ocorre porque o K é um elemento muito móvel na planta, com alta mobilidade intracelular e nos tecidos, translocando-se dos tecidos mais velhos para os mais novos e sendo transportado a longa distância via xilema e floema (MEURER, 2006). Yorinori (2003) durante a safra das águas, observou que as maiores taxas de acúmulo de $\mathrm{K}$ na cultivar Atlantic foram de $6,5 \mathrm{~kg} \mathrm{ha}^{-1} \mathrm{dia}^{-1}$ e ocorreram entre 63 e 69 DAP, ou seja, foram inferiores apenas às observadas para a cultivar Mondial no presente estudo (Figura 13B e Tabela 14). De maneira geral, em todas as cultivares estudadas as maiores taxas de acúmulo de $\mathrm{K}$ ocorreram antes das relatadas por Yorinori (2003).

Tabela 15. Percentual de $\mathrm{K}$ acumulado pelas plantas em cada fase do desenvolvimento das cultivares de batata (valores obtidos nas equações ajustadas).

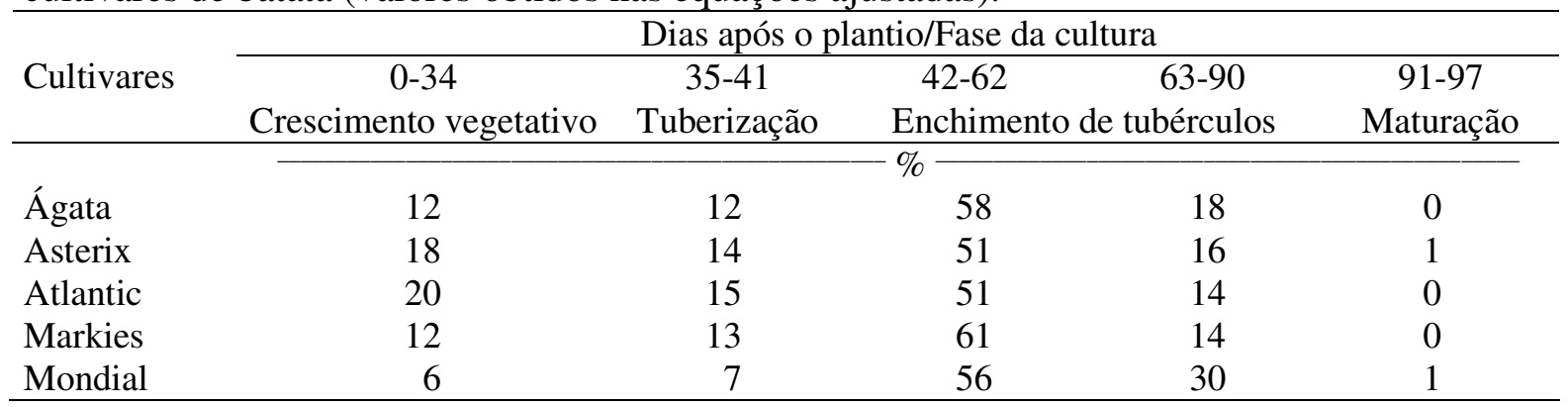




\subsubsection{Cálcio}

Diferente do observado para os nutrientes $\mathrm{N}, \mathrm{P}$, e K, houve aumento gradativo nos teores de $\mathrm{Ca}$ dos tubérculos-semente, raízes, hastes e folhas, sendo os maiores teores observados nas últimas avaliações (Tabela 16). Aos 20 DAP as raízes apresentaram os maiores teores de $\mathrm{Ca}$ e, a partir dos $27 \mathrm{DAP}$ as folhas passaram a apresentar os maiores teores desse elemento até o final do ciclo. Resultados semelhantes foram obtidos por Gargantini et al. (1963), que observaram os maiores teores de Ca nas folhas a partir dos 60 dias de idade das plantas. Nos demais órgãos das plantas, apenas na cultivar Atlantic observaram-se teores de $\mathrm{Ca}$ nas raízes maiores que nas hastes, pois, em todas as demais cultivares as hastes apresentaram maiores teores que as raízes, durante todo o ciclo. Nos tubérculos foram obtidos os menores teores de $\mathrm{Ca}$, os quais se mantiveram relativamente constante do início da tuberização ao final do ciclo. Nas raízes os menores teores de $\mathrm{Ca}$ em todas as avaliações foram observados na cultivar Markies, enquanto nas hastes os menores teores ocorrem na cultivar Mondial no período compreendido dos 55 DAP até a avaliação final.

Com relação as quantidades de Ca presente nos tubérculos-semente, observa-se que as mesmas apresentaram variações, mas, permaneceram relativamente constantes durante o período de avaliação (Figura 14A). Apesar da redução na MS dos tubérculos-semente (Figura 5A) do plantio até aos 62 DAP, a quantidade de Ca nesse período permaneceu constante, devido ao aumento no teor de Ca dos tubérculos-semente (Tabela 16). A quantidade de Ca nos tubérculos-semente da cultivar Asterix foi superior ao observado na cultivar Mondial do plantio até aos 49 DAP, porém, na última avaliação apenas na cultivar Atlantic obteve-se maior quantidade de Ca que a cultivar Mondial. O fato da quantidade de $\mathrm{Ca}$ dos tubérculos-semente não ter diminuído com o decorrer do ciclo, se explica em parte, devido a insolubilidade dos compostos de Ca da planta e sua localização na célula como integrante dos pectatos de Ca na lamela média da parede celular, fato esse que contribui para a baixa redistribuição do Ca (MALAVOLTA, 1980; MALAVOLTA, 2006). 
Tabela 16. Teor de Ca em cada parte das plantas de cultivares de batata durante o ciclo da cultura.

\begin{tabular}{|c|c|c|c|c|c|c|c|c|c|c|c|c|c|}
\hline \multirow{2}{*}{ Cultivares } & \multicolumn{13}{|c|}{ Dias após o plantio } \\
\hline & 0 & 20 & 27 & 34 & 41 & 48 & 55 & 62 & 69 & 76 & 83 & 90 & 97 \\
\hline & \multicolumn{13}{|c|}{$\mathrm{g} \mathrm{kg}^{-1}-$} \\
\hline Ágata & 2 & 3 & 4 & 6 & 7 & 8 & 13 & 13 & - & - & - & - & - \\
\hline Asterix & 2 & 2 & 7 & 11 & 15 & 14 & 16 & 18 & - & - & - & - & - \\
\hline Atlantic & 2 & 2 & 5 & 9 & 10 & 11 & 16 & 18 & - & - & - & - & - \\
\hline Markies & 2 & 2 & 5 & 8 & 11 & 14 & 17 & 16 & - & - & - & - & - \\
\hline \multirow[t]{2}{*}{ Mondial } & 2 & 2 & 3 & 5 & 9 & 9 & 12 & 15 & - & - & - & - & - \\
\hline & \multicolumn{13}{|c|}{ Raízes } \\
\hline Ágata & - & 10 & 9 & 9 & 9 & 9 & 10 & 11 & 10 & 13 & 16 & 15 & 12 \\
\hline Asterix & - & 11 & 10 & 10 & 10 & 10 & 12 & 11 & 11 & 14 & 13 & 14 & 14 \\
\hline Atlantic & - & 15 & 14 & 16 & 15 & 17 & 18 & 19 & 19 & 22 & 24 & 24 & 21 \\
\hline Markies & - & 9 & 7 & 7 & 7 & 8 & 9 & 9 & 9 & 10 & 11 & 13 & 12 \\
\hline Mondial & - & 10 & 12 & 11. & 11 & 11 & 12. & 15 & 13 & 15 & 18 & 19 & 18 \\
\hline \multicolumn{14}{|c|}{ Hastes } \\
\hline Ágata & - & 8 & 13 & 15 & 13 & 14 & 18 & 18 & 19 & 21 & 24 & 22 & 23 \\
\hline Asterix & - & 10 & 16 & 18 & 16 & 17 & 21 & 22 & 22 & 24 & 26 & 27 & 29 \\
\hline Atlantic & - & 9 & 12 & 12 & 13 & 15 & 17 & 18 & 17 & 22 & 23 & 23 & 25 \\
\hline Markies & - & 6 & 10 & 13 & 11 & 13 & 17 & 15 & 17 & 18 & 20 & 22 & 21 \\
\hline Mondial & - & 6 & 11 & 14 & 13 & 13 & 13 & 13 & 12 & 13 & 14 & 16 & 17 \\
\hline \multicolumn{14}{|c|}{ Folhas } \\
\hline Ágata & - & 7 & 14 & 18 & 19 & 22 & 32 & 28 & 30 & 37 & 43 & 46 & 45 \\
\hline Asterix & - & 6 & 15 & 18 & 18 & 20 & 26 & 27 & 30 & 32 & 41 & 43 & 47 \\
\hline Atlantic & - & 9 & 16 & 18 & 17 & 18 & 23 & 25 & 25 & 25 & 29 & 27 & 31 \\
\hline Markies & - & 7 & 18 & 20 & 21 & 25 & 35 & 35 & 37 & 36 & 43 & 41 & 48 \\
\hline Mondial & - & 6 & 13 & 14 & 16 & 19 & 26 & 21 & 28 & 25 & 30 & 37 & 39 \\
\hline \multicolumn{14}{|c|}{ Tubérculos } \\
\hline Ágata & - & - & - & 1 & 1 & 1 & 1 & 1 & 1 & 1 & 1 & 1 & 1 \\
\hline Asterix & - & - & - & 1 & 1 & 1 & 1 & 1 & 1 & 1 & 1 & 1 & 1 \\
\hline Atlantic & - & - & - & 1 & 1 & 1 & 1 & 1 & 1 & 1 & 1 & 1 & 1 \\
\hline Markies & - & - & - & 1 & 2 & 1 & 1 & 1 & 1 & 1 & 1 & 1 & 1 \\
\hline Mondial & - & - & - & 1 & 1 & 2 & 2 & 1 & 1 & 1 & 1 & 1 & 1 \\
\hline
\end{tabular}



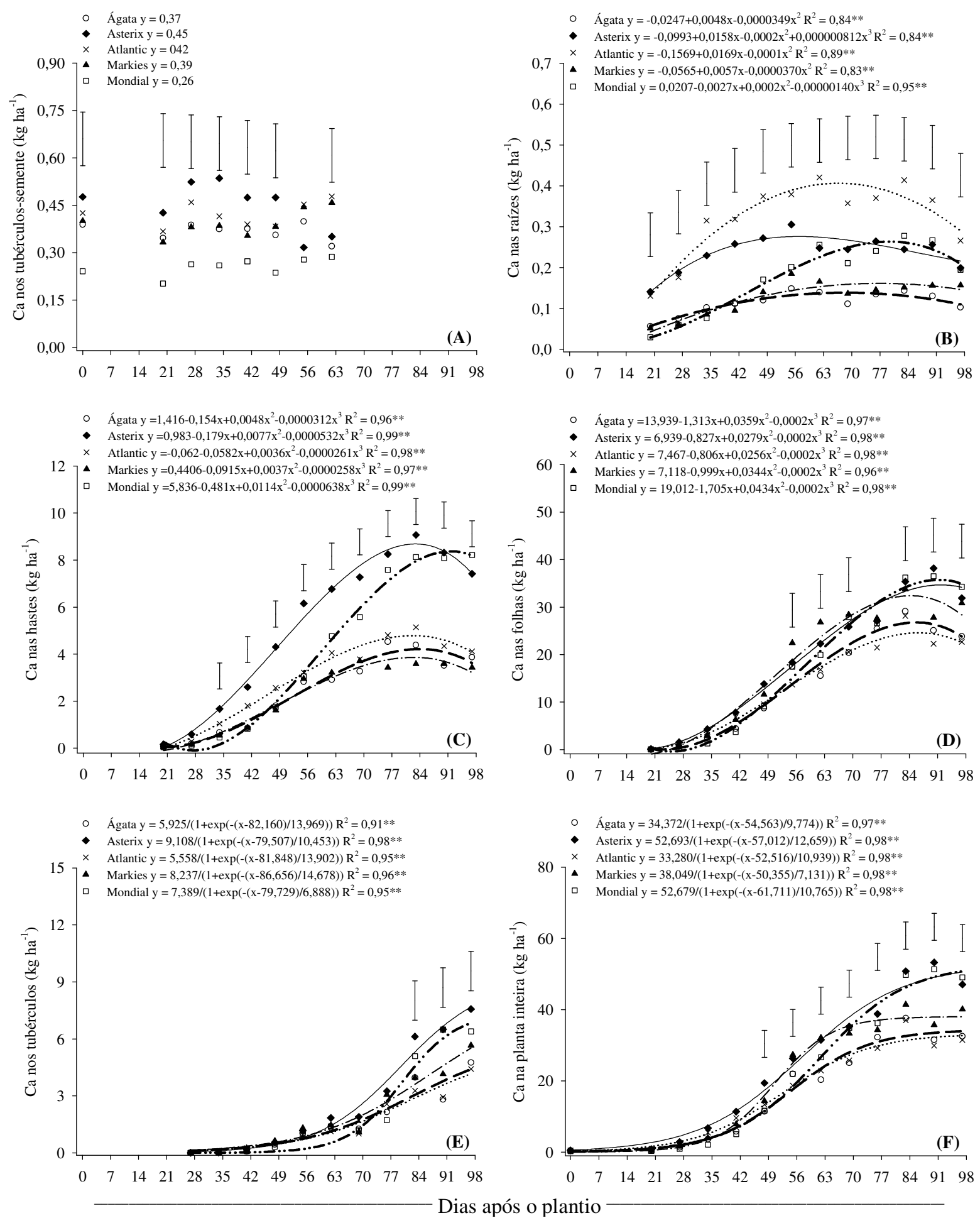

Figura 14. Quantidade de Ca nos tubérculos-semente (A), raízes (B), hastes (C), folhas (D), tubérculos $(\mathrm{E})$ e na planta inteira $(\mathrm{F})$ de cultivares de batata ao longo do ciclo. ** significativo a $1 \%$ de probabilidade pelo teste F. Barras verticais indicam o valor de DMS pelo teste Tukey a $5 \%$ de probabilidade. 
Os acúmulos de $\mathrm{Ca}$ nas raízes aumentaram inicialmente de forma diferente entre as cultivares, atingindo os máximos acúmulos de 0,14, 0,27, 0,41, 0,26 e 0,26 $\mathrm{kg} \mathrm{ha}^{-1}$ aos 68, 56, 66, 76 e 79 DAP para as cultivares Ágata, Asterix, Atlantic, Markies e Mondial, respectivamente (Figura 14B). Da emergência até aos 41 DAP o acúmulo de Ca nas raízes das cultivares Asterix e Atlantic foram maiores que nas demais, no entanto, após esse período intensificou-se o acúmulo de Ca nas raízes da cultivar Mondial, o que proporcionou acúmulo semelhante desse elemento nas raízes das culivares Mondial e Asterix dos 48 DAP até o final do ciclo. Esse comportamento semelhante entre as cultivares Mondial e Asterix, ocorreu devido a presença dos maiores teores de $\mathrm{Ca}$ nas raízes da cultivar Mondial em comparação a Asterix a partir dos 62 DAP (Tabela 16). Embora, a cultivar Atlantic tenha apresentado acúmulo de $\mathrm{Ca}$ semelhante a Asterix, praticamente durante todo o ciclo, no período compreendido entre 34 e 83 DAP o acúmulo de Ca nas raízes da cultivar Atlantic foi superior ao de todas as demais cultivares, o que ocorreu em função dos maiores teores de Ca obtidos nas raízes dessa cultivar (Tabela 16). Yorinori (2003) observou acúmulo máximo de Ca nas raízes da cultivar Atlantic de $0,27 \mathrm{~kg} \mathrm{ha}^{-1}$ na safra das águas (74 DAP) e 0,19 $\mathrm{kg} \mathrm{ha}^{-1}$ na safra das secas (48 DAP), os quais foram inferiores aos observados no presente experimento para a mesma cultivar, porém, semelhante à Asterix e Mondial.

Nas hastes, os acúmulos de Ca não diferiram entre as cultivares desde a emergência até aos 27 DAP e, a partir dos 34 DAP, as quantidades de Ca acumuladas nas hastes aumentaram de maneira diferente entre as cultivares (Figura 14C). A partir dos 48 DAP, a cultivar Asterix apresentou acúmulo de Ca em suas hastes superior ao observado em todas as demais cultivares, porém, com o aumento intenso da quantidade de Ca acumulada nas hastes da cultivar Mondial até próximo ao final do ciclo, ambas as cultivares passaram a apresentar quantidades acumuladas semelhantes desse elemento nessa época, as quais foram superiores àquelas observados nas demais cultivares. Observa-se que apesar do aumento de MS nas hastes da cultivar Mondial ter sido superior ao obtido na cultivar Asterix na fase final do ciclo (Figura 5C), ambas as cultivares acumularam $\mathrm{Ca}$ de forma semelhante nesse período, o que, sem dúvida, deveu-se aos maiores teores de $\mathrm{Ca}$ encontrados nas hastes da cultivar Asterix (Tabela 16). As quantidades máximas de Ca acumuladas nas hastes foram estimadas em 4,2, 8,7, 4,8, 3,8 e 8,4 $\mathrm{kg} \mathrm{ha}^{-1}$ aos 84, 83, 82, 82 e 91 DAP, respectivamente, para as cultivares Ágata, Asterix, Atlantic, Markies e Mondial. Vale ressaltar que as cultivares Asterix 
e Mondial, possuem comportamento semelhante quanto ao acúmulo de Ca tanto nas raízes quanto nas hastes durante a fase final do ciclo (Figura 14C), porém, enquanto Mondial tem como característica concentrar mais Ca nas raízes em relação às hastes (maior teor), a Asterix o faz nas hastes (Tabela 16).

Verificou-se pequenos acúmulos de Ca nas folhas durante a fase de crescimento vegetativo e, a partir dos 41 DAP, as quantidades acumuladas aumentaram sem diferir entre as cultivares até aos 48 DAP (Figura 14D). Entre 55 e 69 DAP, o acúmulo de Ca nas folhas da cultivar Markies foi superior ao observado na cultivar Atlantic e, a partir dos 76 DAP, o acúmulo de Ca nas folhas de ambas as cultivares tornaram-se semelhantes até aos 90 DAP, possivelmente, em função dos maiores teores de Ca observados nas folhas da cultivar Markies em comparação à Atlantic. No final do ciclo, as cultivares Asterix e Mondial apresentaram maior acúmulo de Ca nas folhas do que as cultivares Ágata e Atlantic. Esse comportamento ocorreu em função das menores quantidades de MS de folhas apresentada por Ágata e, devido ao fato dos teores de Ca nas folhas da cultivar Atlantic serem inferiores aos observados em Asterix durante esse período. $\mathrm{O}$ acúmulo de $\mathrm{Ca}$ nas folhas atingiu os valores máximos estimados de 26,7, 34,7, 24,6, 32,4 e 35,7 $\mathrm{kg} \mathrm{ha}^{-1}$, aos 85, 92, 86, 84 e 90 DAP nas cultivares Ágata, Asterix, Atlantic, Markies e Mondial, respectivamente. De maneira geral, foram observadas reduções no acúmulo de $\mathrm{Ca}$ das folhas de todas as cultivares estudadas durante a fase final do ciclo, o que em parte, provavelmente ocorreu devido a queda de folhas (Figura 3B), que refletiu diminuição da MS (Figura 5D) desse órgão na planta, uma vez que esse elemento é conhecidamente muito pouco translocado.

Os tubérculos acumularam Ca lentamente até próximo aos 69 DAP, sendo que a partir dos 76 DAP houve aumento gradativo das quantidades acumuladas até o final do ciclo, atingindo os acúmulos máximos estimados de 4, 8, 4, 5 e $7 \mathrm{~kg} \mathrm{ha-1}$, respectivamente, pelas cultivares Ágata, Asterix, Atlantic, Markies e Mondial, aos 97 DAP (Figura 14E). Da tuberização até aos 76 DAP, o acúmulo de Ca nos tubérculos de todas as cultivares foram semelhantes. Entre 83 e 97 DAP, a cultivar Asterix apresentou acúmulo de Ca nos tubérculos superior ao observado nas cultivares Ágata e Atlantic, o qual ocorreu por diferenças entre o acúmulo de MS nos tubérculos (Figura 5E), uma vez que o teor de Ca nesse órgão foi semelhante entre as cultivares (Tabela 16). 
No final do ciclo, as quantidades de $\mathrm{Ca}$ acumuladas nos tubérculos corresponderam a aproximadamente $16 \%$ do total acumulado pelas plantas da cultivar Asterix e, entre 11 e 13\% do total acumulado pelas plantas das demais cultivares (Figura 14E). Yorinori (2003) durante a safra das águas e das secas, observou que de todo o Ca acumulado pelas plantas da cultivar Atlantic entre 13 e $12 \%$ estavam presentes nos tubérculos, respectivamente. Esses dados estão de acordo com os observados no presente experimento. No entanto, Paula et al. (1986) relataram que apenas 5\% da quantidade total de Ca absorvida estavam nos tubérculos, independente da adubação e da cultivar. Esse baixo acúmulo de Ca nos tubérculos ocorreu principalmente pelo fato que esse elemento é pouco móvel no floema (MALAVOLTA, 2006) o que pode ser comprovado pelas baixas taxas diárias de acúmulo de Ca nos tubérculos (Figura 15A e Tabela 17). Embora as taxas diárias de acúmulo de Ca nos tubérculos das cultivares de batata tenham apresentado um pico de maior acúmulo, este foi pequeno, atingindo apenas incrementos da ordem de 0,$11 ; 0,22 ; 0,10 ; 0,14 \mathrm{e} 0,27 \mathrm{~kg} \mathrm{ha}^{-1} \mathrm{dia}^{-1}$, respectivamente, para as cultivares Ágata, Asterix, Atlantic, Markies e Mondial aos 82, 79, 81, 86, 79 DAP (Figura 15A e Tabela 17).
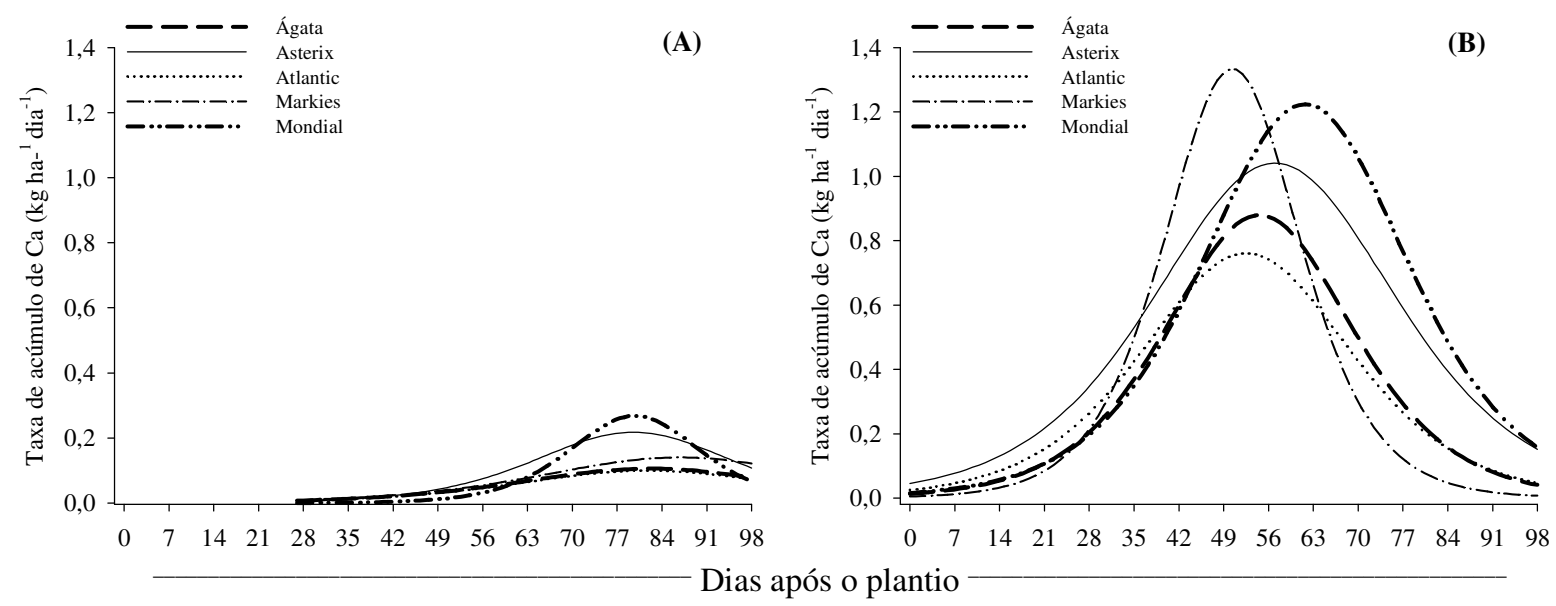

Figura 15. Taxa de acúmulo de Ca nos tubérculos (A) e nas plantas (B) de cultivares de batata ao longo do ciclo. 
Tabela 17. Quantidade máxima de Ca acumulada, taxa diária máxima de acúmulo e época de maior taxa de acúmulo de Ca nos tubérculos e nas plantas de cultivares de batata.

\begin{tabular}{lcccccc}
\hline Cultivares & $\begin{array}{c}\text { Acúmulo } \\
\text { máximo no } \\
\text { tubérculo }\end{array}$ & $\begin{array}{c}\text { Taxa } \\
\text { máxima de } \\
\text { acúmulo no } \\
\text { tubérculo }\end{array}$ & $\begin{array}{c}\text { Época de } \\
\text { maior taxa } \\
\text { de acúmulo } \\
\text { no tubérculo }\end{array}$ & $\begin{array}{c}\text { Acúmulo } \\
\text { máximo na } \\
\text { planta }\end{array}$ & $\begin{array}{c}\text { Taxa } \\
\text { máxima de } \\
\text { acúmulo na } \\
\text { planta }\end{array}$ & $\begin{array}{c}\text { Época de } \\
\text { maior taxa de } \\
\text { acúmulo na } \\
\text { planta }\end{array}$ \\
\hline Ágata & $\mathrm{kg} \mathrm{ha}^{-1}$ & $\mathrm{~kg} \mathrm{ha}^{-1} \mathrm{dia}^{-1}$ & DAP & $\mathrm{kg} \mathrm{ha}^{-1}$ & $\mathrm{~kg} \mathrm{ha}^{-1} \mathrm{dia}^{-1}$ & $\mathrm{DAP}$ \\
Asterix & 4 & 0,11 & 82 & 34 & 0,88 & 55 \\
Atlantic & 8 & 0,22 & 79 & 50 & 1,04 & 56 \\
Markies & 4 & 0,10 & 81 & 33 & 0,76 & 53 \\
Mondial & 5 & 0,14 & 86 & 38 & 1,33 & 50 \\
\hline
\end{tabular}

Considerando a planta inteira, as quantidades de $\mathrm{Ca}$ acumuladas foram pequenas e não diferiram entre as cultivares nos primeiros $41 \mathrm{DAP}$, com os dados sendo ajustados a modelos sigmóides de regressão (Figura 14F). No entanto, nota-se que da emergência até aos 34 DAP, a absorção de Ca foi pequena (Figura 14F), uma vez que a cultivar Mondial absorveu apenas 7\% de todo o Ca acumulado durante o ciclo e as cultivares Asterix e Atlantic, absorveram uma maior proporção durante esse período, ou seja, entre 15 e 16\%. Essa menor proporção de absorção de Ca na cultivar Mondial em comparação a Asterix e Atlantic, durante as fases iniciais está relacionada com as baixas taxas diárias de absorção desse elemento nesse período (Figura 15B). Aos 48 DAP a cultivar Mondial apresentou menor acúmulo de Ca em comparação a cultivar Asterix, pois, desde a emergência até essa época, as taxas diárias de absorção de $\mathrm{Ca}$ na cultivar Asterix foram superiores àquelas obtidas na cultivar Mondial (Figura 14F e 15B). No entanto, a partir dos 55 DAP, quando as taxas diárias de absorção de Ca na cultivar Mondial passaram a ser maiores do que na cultivar Asterix, o acúmulo de $\mathrm{Ca}$ em ambas cultivares tornou-se semelhante até o final do ciclo e, superior ao das demais cultivares entre os 83 e 90 DAP.

No início da fase de enchimento dos tubérculos (42 a 62 DAP) quando ocorreram as maiores taxas diárias de absorção de Ca na cultivar Markies, observou-se as maiores porcentagens de absorção de Ca nessa cultivar, a qual absorveu em torno de $63 \%$ de todo o Ca acumulado (Figura 15B e Tabela 18). Nesse período as cultivares Asterix e Mondial absorveram as menores proporções de $\mathrm{Ca}(40 \%)$ em relação ao total extraído. No entanto, durante todo o estádio de enchimento dos tubérculos (42 a 90 DAP) a cultivar Mondial 
absorveu próximo de $84 \%$ da quantidade total de $\mathrm{Ca}$, o que é reflexo da ocorrência das maiores taxas de absorção de Ca no período final desse estádio de desenvolvimento (Figura 15B e Tabela 18). Gargantini et al. (1963) em estudo sobre a marcha de absorção de nutrientes pela cultivar Bintje, observou que aos 40 DAP as plantas dessa cultivar haviam retirado do solo $24 \%$ do total de Ca absorvido e aos 60 DAP esse valor aumentou para cerca de $73 \%$ do total. Esses dados são semelhantes aos obtidos com as cultivares Asterix e Atlantic até aos 41 DAP e Atlantic até aos 62 DAP.

No final do ciclo o acúmulo máximo de Ca foi estimado em 34, 50, 33, 38 e $51 \mathrm{~kg} \mathrm{ha}^{-1}$ nas cultivares Ágata, Asterix, Atlantic, Markies e Mondial, respectivamente (Figura 14F e Tabela 17). Yorinori (2003) para a cultivar Atlantic, obteve acúmulos totais de Ca de $21,7 \mathrm{~kg} \mathrm{ha}^{-1}$ (safra das águas) e $14,6 \mathrm{~kg} \mathrm{ha}^{-1}$ (safra das secas) aos 92 e 55 DAP, respectivamente, os quais foram inferiores ao observado no presente experimento.

As taxas diárias de absorção de Ca foram crescentes da emergência até em torno dos 50 a 61 DAP, sofrendo reduções após esse período (Figura 15 e Tabela 17). Porém, as maiores taxas diárias de absorção de Ca pelas plantas foram em média 6 vezes maiores que as máximas taxas de alocação de Ca nos tubérculos, demonstrando que embora ocorra um período de maior absorção de Ca pelas plantas, esse elemento é pouco translocado para os tubérculos, pois, as máximas taxas de acúmulo de Ca nos tubérculos ocorridas entre 79 e 86 DAP, ou seja, após o período de maior absorção pelas plantas, foram baixas. Além disso, observa-se que apesar das cultivares terem apresentado o pico de maior absorção de Ca entre os 50 e 61 DAP, a absorção do Ca seguiu o comportamento observado para o P, ou seja, com absorção continua da emergência até o final do ciclo, pois, o aumento na taxa diária de absorção foi pequeno durante esse período. Esses resultados confirmam os relatos de Gargantini et al. (1963) de que o Ca e o P são absorvidos continuamente pela batateira do início ao final do ciclo.

Vale ressaltar que as maiores quantidades acumuladas de Ca foram observadas nas folhas, seguido das hastes, tubérculos, tubérculos-semente e raízes (Figura 14), diferente do observado para os elementos $\mathrm{N}, \mathrm{P}$ e $\mathrm{K}$, os quais tiveram maiores acúmulos nos tubérculos (Figuras 8, 10 e 12). Fica evidente que o Ca é absorvido pelas raízes e transportado via xilema para a parte aérea indo se acumular nas folhas sem sofrer grande redistribuição dentro da planta (MALAVOLTA, 2006). 
Tabela 18. Percentual de Ca acumulado pelas plantas em cada fase do desenvolvimento das cultivares de batata (valores obtidos nas equações ajustadas).

\begin{tabular}{|c|c|c|c|c|c|}
\hline \multirow{3}{*}{ Cultivares } & \multicolumn{5}{|c|}{ Dias após o plantio/Fase da cultura } \\
\hline & $0-34$ & $35-41$ & $42-62$ & $63-90$ & 91-97 \\
\hline & Crescimento vegetativo & Tuberização & Enchim & bérculos & Maturação \\
\hline Ágata & 11 & 9 & 49 & 30 & 1 \\
\hline Asterix & 15 & 8 & 40 & 34 & 3 \\
\hline Atlantic & 16 & 10 & 46 & 27 & 1 \\
\hline Markies & 9 & 12 & 63 & 16 & 0 \\
\hline Mondial & 7 & 6 & 40 & 44 & 3 \\
\hline
\end{tabular}

A baixa translocação de Ca para os tubérculos já havia sido relatada por Kratzke e Palta (1986), em estudo sobre acúmulo de Ca nos tubérculos da batateira e o papel das raízes basais na contribuição do acúmulo de Ca neste órgão. Estes autores observaram que o acúmulo de Ca nos tubérculos da batateira não aumentou com o aumento da dose de Ca nas raízes basais, separadamente dos estolões e tubérculos, e então, sugeriram que as raízes basais não contribuem para o acúmulo de Ca nos tubérculos e que o Ca presente nos tubérculos é absorvido, em sua maior parte, diretamente pelos estolões e por pêlos absorventes existentes nos tubérculos.

\subsubsection{Magnésio}

Da mesma forma que ocorreu com o $\mathrm{Ca}$, houve aumento dos teores de $\mathrm{Mg}$ nos tubérculos-semente do plantio até aos $62 \mathrm{DAP}$, sendo que na última avaliação os teores observados nos tubérculos-sementes das cultivares Asterix, Atlantic e Markies foram superiores aos obtidos em todas as demais partes das plantas (Tabela 19). Nas raízes os teores de Mg mantiveram-se relativamente constante até aos 62 DAP, sendo que desse período em diante, diminuiu continuamente até o final do ciclo. Gargantini et al. (1963) observou comportamento semelhante para concentração de $\mathrm{Mg}$ nas raízes da cultivar Bintje, a qual apresentou teor constante até aos 70 DAP, com redução continua até o final do ciclo, chegando a ser $25 \%$ menor que a concentração inicial. 
Tabela 19. Teor de Mg em cada parte das plantas de cultivares de batata durante o ciclo da cultura.

\begin{tabular}{|c|c|c|c|c|c|c|c|c|c|c|c|c|c|}
\hline \multirow{2}{*}{ Cultivares } & \multicolumn{13}{|c|}{ Dias após o plantio } \\
\hline & 0 & 20 & 27 & 34 & 41 & 48 & 55 & 62 & 69 & 76 & 83 & 90 & 97 \\
\hline & \multicolumn{13}{|c|}{$\begin{array}{l}\mathrm{g} \mathrm{kg}^{-1} \\
\text { Tubérculos-semente }\end{array}$} \\
\hline Ágata & 1,9 & 2,5 & 2,6 & 3,5 & 3,9 & 4,1 & 4,9 & 4,9 & - & - & - & - & - \\
\hline Asterix & 1,4 & 2,0 & 3,6 & 4,3 & 4,9 & 5,4 & 5,4 & 5,5 & - & - & - & - & - \\
\hline Atlantic & 1,1 & 1,8 & 2,8 & 4,2 & 5,5 & 5,6 & 6,3 & 6,7 & - & - & - & - & - \\
\hline Markies & 1,6 & 1,9 & 2,9 & 4,0 & 5,5 & 6,1 & 6,5 & 6,3 & - & - & - & - & - \\
\hline Mondial & 1,4 & 1,7 & 2,1 & 3,1 & 5,2 & 5,5 & 5,5 & 6,6 & - & - & - & - & - \\
\hline & \multicolumn{13}{|c|}{ Raízes } \\
\hline Ágata & - & 4,3 & 4,0 & 4,0 & 4,4 & 3,7 & 3,8 & 4,1 & 3,6 & 3,7 & 3,4 & 2,5 & 1,9 \\
\hline Asterix & - & 3,6 & 3,2 & 3,2 & 3,5 & 3,2 & 3,3 & 2,6 & 2,6 & 2,7 & 2,1 & 2,1 & 1,9 \\
\hline Atlantic & - & 3,4 & 2,8 & 2,9 & 3,3 & 3,2 & 3,1 & 3,0 & 3,1 & 3,0 & 2,8 & 2,2 & 1,9 \\
\hline Markies & - & 3,7 & 3,5 & 3,4 & 4,1 & 4,0 & 4,0 & 4,1 & 3,7 & 3,6 & 3,5 & 2,9 & 2,7 \\
\hline Mondial & - & 4,1 & 3,7 & 4,3 & 5,1 & 4,9 & 4,2 & 4,9 & 4,3 & 4,2 & 4,0 & 3,1 & 2,8 \\
\hline & \multicolumn{13}{|c|}{ Hastes } \\
\hline Ágata & - & 2,0 & 1,9 & 2,5 & 2,9 & 2,8 & 2,8 & 2,8 & 2,6 & 2,8 & 3,0 & 2,4 & 2,0 \\
\hline Asterix & - & 2,0 & 2,5 & 3,5 & 3,7 & 4,0 & 4,5 & 5,1 & 4,7 & 5,1 & 5,4 & 5,9 & 5,9 \\
\hline Atlantic & - & 2,7 & 2,9 & 3,9 & 4,6 & 4,9 & 5,4 & 5,5 & 5,2 & 5,9 & 6,4 & 6,4 & 7,4 \\
\hline Markies & - & 1,8 & 2,1 & 2,5 & 3,2 & 3,2 & 3,4 & 2,9 & 2,7 & 2,5 & 2,6 & 3,0 & 2,8 \\
\hline Mondial & - & 1,9 & 2,3 & 3,2 & 4,2 & 4,6 & 4,3 & 4,3 & 3,6 & 4,1 & 4,2 & 4,1 & 4,6 \\
\hline & \multicolumn{13}{|c|}{ Folhas } \\
\hline Ágata & - & 2,6 & 3,2 & 4,0 & 5,2 & 5,3 & 5,7 & 5,3 & 4,4 & 4,6 & 5,2 & 3,6 & 2,8 \\
\hline Asterix & - & 2,2 & 3,7 & 4,4 & 5,0 & 5,6 & 5,3 & 5,1 & 4,8 & 4,8 & 4,7 & 4,3 & 3,2 \\
\hline Atlantic & - & 2,9 & 4,1 & 4,3 & 4,9 & 5,4 & 5,6 & 5,4 & 5,0 & 5,0 & 5,1 & 4,2 & 4,4 \\
\hline Markies & - & 2,8 & 4,4 & 4,5 & 5,5 & 6,0 & 6,4 & 7,1 & 6,2 & 5,8 & 5,4 & 4,7 & 4,4 \\
\hline Mondial & - & 3,2 & 3,8 & 4,5 & 5,5 & 6,4 & 6,8 & 6,1 & 6,7 & 6,0 & 5,9 & 5,9 & 5,5 \\
\hline & \multicolumn{13}{|c|}{ Tubérculos } \\
\hline Ágata & - & - & - & 1,5 & 1,5 & 1,6 & 1,2 & 1,3 & 1,5 & 1,3 & 1,5 & 1,4 & 1,1 \\
\hline Asterix & - & - & - & 1,3 & 1,4 & 1,5 & 1,2 & 1,1 & 1,1 & 1,1 & 1,3 & 1,3 & 1,2 \\
\hline Atlantic & - & - & - & 1,1 & 1,2 & 1,1 & 0,9 & 1,0 & 1,0 & 1,1 & 1,1 & 1,0 & 1,1 \\
\hline Markies & - & - & - & 1,4 & 1,6 & 1,6 & 1,5 & 1,2 & 1,4 & 1,5 & 1,5 & 1,3 & 1,2 \\
\hline Mondial & - & - & - & 1,4 & 1,4 & 1,3 & 1,4 & 1,3 & 1,2 & 1,3 & 1,4 & 1,1 & 1,1 \\
\hline
\end{tabular}

Nas hastes, com exceção da cultivar Ágata que apresentou teores mais ou menos constante da emergência até aos 97 DAP, em todas as demais cultivares ocorreu aumento nos teores de $\mathrm{Mg}$ durante todo o ciclo, sendo que, nas hastes da cultivar Atlantic encontraram-se os maiores teores de desse elemento (Tabela 19). Os teores de Mg nas folhas aumentaram desde a emergência das plantas até aos 62 DAP e após esse período diminuíram até o final do ciclo. Quanto ao teor de $\mathrm{Mg}$ nos tubérculos, este foi relativamente constante durante todo o ciclo e bem menor do que os encontrados nos outros órgãos das plantas. $\mathrm{Na}$ 
primeira avaliação o maior teor inicial de $\mathrm{Mg}$ ocorreu nas raízes, seguida das folhas, hastes e tubérculos-semente. Porém entre os 27 e $41 \mathrm{DAP}$, os maiores teores de Mg foram observados nas folhas e, a partir dos 48 DAP até o final do ciclo ocorreram variações entre o teor observado nas folhas e hastes.

As quantidades de $\mathrm{Mg}$ presentes nos tubérculos-semente diminuíram linearmente do momento do plantio até aos 62 DAP em todas as cultivares estudadas (Figura 16A). No plantio os tubérculos-semente das cultivares Asterix e Ágata continham maiores quantidades de $\mathrm{Mg}$, em comparação a cultivar Mondial e, aos 20 DAP, apenas a cultivar Asterix apresentou maiores quantidades de Mg que Mondial. Dos 27 DAP até a última avaliação os tubérculos-semente de todas as cultivares apresentaram quantidades semelhantes de Mg.

Nas raízes, os acúmulos de $\mathrm{Mg}$ aumentaram inicialmente até atingir as quantidades máximas estimadas de 0,054, 0,087, 0,070, 0,074 e 0,082 $\mathrm{kg} \mathrm{ha}^{-1}$ aos 53, 40, 55, 59 e 63 DAP nas cultivares Ágata, Asterix, Atlantic, Markies e Mondial, respectivamente (Figura 16B). A cultivar Asterix foi a mais precoce em atingir o acúmulo máximo de Mg nas raízes, pois, no período compreendido entre a emergência e os 41 DAP esta cultivar apresentou os maiores acúmulos de Mg nas raízes (exceção feita apenas à Atlantic aos 34 DAP). Embora o acúmulo de Mg nas raízes da cultivar Mondial tenha sido pequeno durante a fase inicial do ciclo, a partir dos 34 DAP, o acúmulo de Mg nas raízes dessa cultivar aumentou mais intensamente e tornou-se semelhante ao das cultivares Asterix, Atlantic e Markies dos 48 DAP até o final do ciclo. O acúmulo tardio de Mg observado nas raízes da cultivar Mondial proporcionou diferenças entre as quantidades desse elemento acumuladas nas raízes das cultivares Mondial e Ágata durante o período de 69 a 83 DAP, período esse, em que ocorreram diminuições do Mg acumulado nas raízes da cultivar Ágata. Dos 55 DAP até o final do ciclo a curva que descreve a acumulação de $\mathrm{Mg}$ nas raízes da cultivar Asterix ficou abaixo das observadas nas cultivares Mondial, Markies e Atlantic, provavelmente, devido aos menores teores de Mg nas raízes de Asterix (Tabela 19), uma vez que a MS radicular foi maior que a das demais (Figura 5B). Yorinori (2003) observou acúmulo máximo de Mg nas raízes da cultivar Atlantic de $0,06 \mathrm{~kg} \mathrm{ha}^{-1}$ na safra das águas (81 DAP) e $0,05 \mathrm{~kg} \mathrm{ha}^{-1}$ na safra das secas (46 DAP), ou seja, inferiores aos observados no presente experimento para a mesma cultivar. 
Os acúmulos de $\mathrm{Mg}$ nas hastes, foram semelhantes entre as cultivares, da emergência até aos 34 DAP e, a partir dos 35 DAP aumentaram as quantidades de $\mathrm{Mg}$ acumuladas nas hastes de todas as cultivares, porém, com intensidades diferentes (Figura 16C). Aos 41 DAP as quantidades de Mg acumuladas nas hastes das cultivares Asterix e Atlantic foram superiores à encontrada na cultivar Mondial. No entanto, a partir dos 48 DAP o acúmulo de $\mathrm{Mg}$ nas hastes da cultivar Mondial aumentou constantemente o que proporcionou acúmulo semelhante de $\mathrm{Mg}$ nas hastes dessas cultivares até aos $55 \mathrm{DAP}$. Na fase final do ciclo, os maiores acúmulos de Mg ocorreram nas hastes das cultivares Mondial, Asterix e Atlantic, respectivamente. Já os menores acúmulos de Mg ocorreram nas cultivares Ágata e Markies. Embora a cultivar Atlantic tenha apresentado acúmulo de MS nas hastes semelhante ao das cultivares Ágata e Markies (Figura 5C), o acúmulo de Mg foi superior, devido ao maior teor de $\mathrm{Mg}$ presente nas hastes dessa cultivar (Tabela 19). As quantidades máximas acumuladas de $\mathrm{Mg}$ nas hastes foram estimadas em 0,55, 1,89, 1,38, 0,57 e 2,41 kg ha-1 aos 76, 81, 81, 75 e 86 DAP, respectivamente, para as cultivares Ágata, Asterix, Atlantic, Markies e Mondial.

Nas folhas, as quantidades de $\mathrm{Mg}$ acumuladas foram semelhantes entre as cultivares até aos 41 DAP (Figura 16D). A partir dos 48 DAP a cultivar Mondial apresentou acúmulo intenso de $\mathrm{Mg}$ nas folhas, sendo superior ao observado na cultivar Ágata até o final do ciclo e maior que o obtido nas demais cultivares entre 69 e 97 DAP. As cultivares Asterix, Atlantic e Markies apresentaram acúmulo semelhante de Mg nas folhas no período entre 69 e 97 DAP. Os acúmulos máximos estimados de Mg nas folhas, ocorreram aos 73, 71, 77, 74 e 78 DAP para as cultivares Ágata, Asterix, Atlantic, Markies e Mondial, com quantidades de $3,39,4,47,4,44,4,87$ e $7,05 \mathrm{~kg} \mathrm{ha}^{-1}$, respectivamente. 

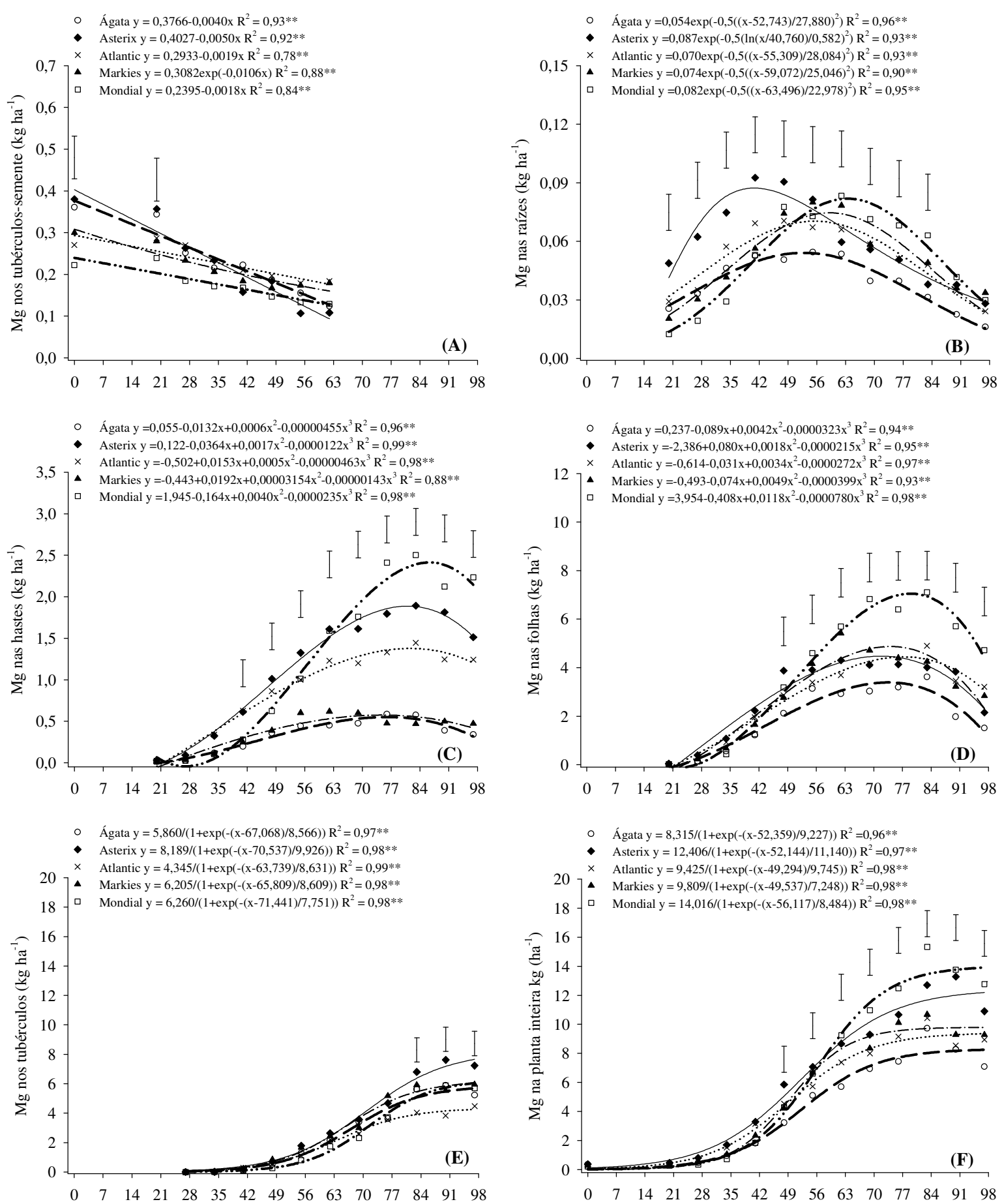

Dias após o plantio

Figura 16. Quantidade de Mg nos tubérculos-semente (A), raízes (B), hastes (C), folhas (D), tubérculos $(\mathrm{E})$ e na planta inteira $(\mathrm{F})$ de cultivares de batata ao longo do ciclo. ** significativo a $1 \%$ de probabilidade pelo teste F. Barras verticais indicam o valor de DMS pelo teste Tukey a $5 \%$ de probabilidade. 
Todas as cultivares apresentaram acúmulo semelhante de $\mathrm{Mg}$ em seus tubérculos do início da tuberização até aos 76 DAP (Figura 16E). Os acúmulos máximos de $\mathrm{Mg}$ nos tubérculos de todas as cultivares ocorreram no final do ciclo, com valores máximos de 6, 8, 4, 6 e $6 \mathrm{~kg} \mathrm{ha}^{-1}$ pelas cultivares Ágata, Asterix, Atlantic, Markies e Mondial, respectivamente. Entre os 83 e 97 DAP o acúmulo de Mg nos tubérculos da cultivar Asterix foi superior ao encontrado na cultivar Atlantic, o que em parte, é resultado da maior quantidade de MS acumulada nos tubérculos da cultivar Asterix (Figura 5E) e das maiores taxas de acúmulo de Mg nos tubérculos dessa cultivar (Figura 17A). No início da fase de enchimento de tubérculos (42 DAP) o acúmulo de Mg foi pequeno, no entanto, no final do ciclo essa parte da planta representou em torno de $75 \%, 66 \%, 44 \%, 60 \%$ e $42 \%$ do total de $\mathrm{Mg}$ acumulado pelas cultivares Ágata, Asterix, Atlantic, Markies e Mondial, respectivamente. Paula et al. (1986) observaram que em torno de 50 e 64\% da quantidade total de $\mathrm{Mg}$ acumulada pelas plantas de batata, cultivar Mantiqueira, estavam presente nos tubérculos, sob condição adubada e sem adubação com NPK, respectivamente. A época de maior taxa de acúmulo de Mg nos tubérculos ocorreu dos 64 a 72 DAP, com incrementos da ordem de 0,20, 0,20, 0,18, $0,17 \mathrm{e} 0,12 \mathrm{~kg} \mathrm{ha}^{-1} \mathrm{dia}^{-1}$ nas cultivares Asterix, Mondial, Markies, Ágata e Atlantic, respectivamente (Figura 17A e Tabela 20).

Considerando as plantas inteiras, os acúmulos de $\mathrm{Mg}$ foram pequenos e semelhantes entre as cultivares nos primeiros 41 DAP, coincidindo com o período de menor acúmulo de MS (Figura 16F). Os baixos acúmulos de $\mathrm{Mg}$ nas fases iniciais de desenvolvimento das plantas ocorreram devido às pequenas absorções desse elemento (Figura 16F), durante a fase de crescimento vegetativo, uma vez que, nessa época as taxas diárias de absorção foram baixas e as cultivares absorveram entre $7 \%$ (Mondial) e 18\% (Atlantic) da quantidade total de Mg (Figura 6B e Tabela 21). 

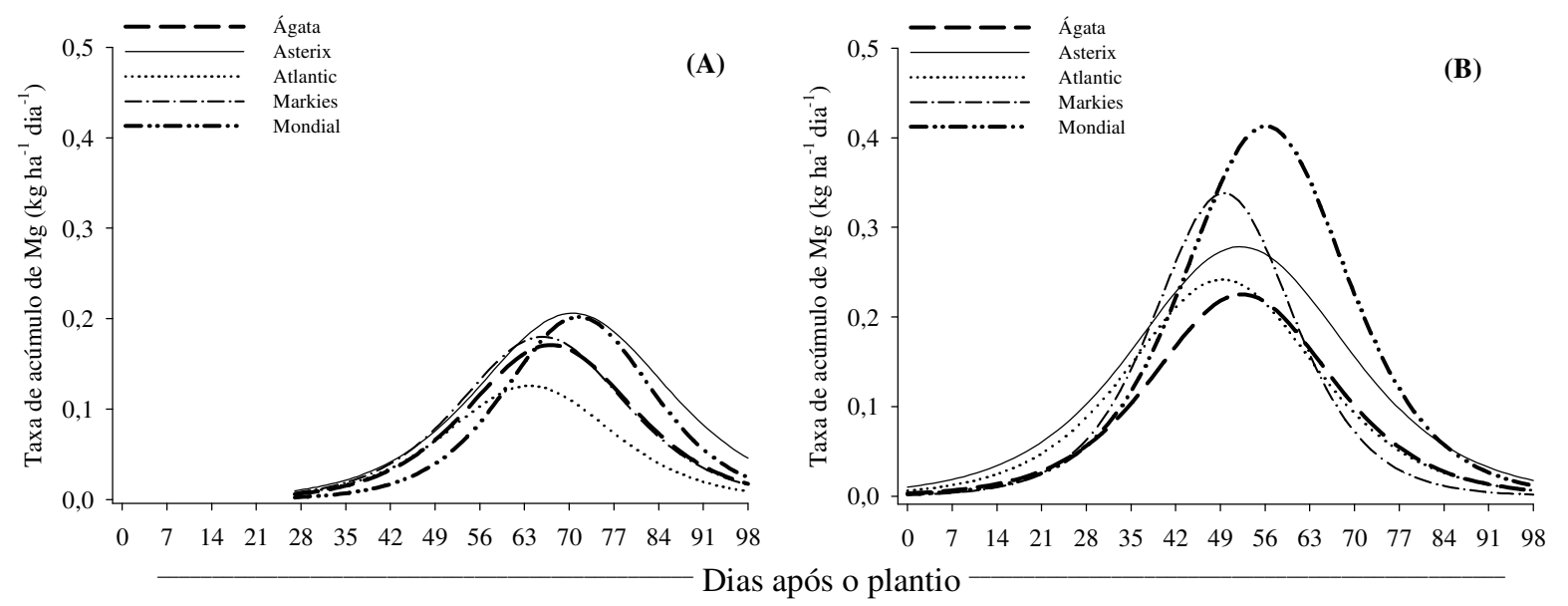

Figura 17. Taxa de acúmulo de $\mathrm{Mg}$ nos tubérculos (A) e nas plantas (B) de cultivares de batata ao longo do ciclo.

Tabela 20. Quantidade máxima de Mg acumulada, taxa diária máxima de acúmulo e época de maior taxa de acúmulo de $\mathrm{Mg}$ nos tubérculos e nas plantas de cultivares de batata.

\begin{tabular}{|c|c|c|c|c|c|c|}
\hline Cultivares & $\begin{array}{l}\text { Acúmulo } \\
\text { máximo no } \\
\text { tubérculo }\end{array}$ & $\begin{array}{c}\text { Taxa } \\
\text { máxima de } \\
\text { acúmulo no } \\
\text { tubérculo }\end{array}$ & $\begin{array}{c}\text { Época de } \\
\text { maior taxa } \\
\text { de acúmulo } \\
\text { no tubérculo }\end{array}$ & $\begin{array}{l}\text { Acúmulo } \\
\text { máximo na } \\
\text { planta }\end{array}$ & $\begin{array}{c}\text { Taxa } \\
\text { máxima de } \\
\text { acúmulo na } \\
\text { planta }\end{array}$ & $\begin{array}{c}\text { Época de } \\
\text { maior taxa de } \\
\text { acúmulo na } \\
\text { planta }\end{array}$ \\
\hline & $\mathrm{kg} \mathrm{ha}^{-1}$ & $\mathrm{~kg} \mathrm{ha}^{-1} \mathrm{dia}^{-1}$ & DAP & $\mathrm{kg} \mathrm{ha}^{-1}$ & $\mathrm{~kg} \mathrm{ha}^{-1} \mathrm{dia}^{-1}$ & DAP \\
\hline Ágata & 6 & 0,17 & 66 & 8 & 0,22 & 52 \\
\hline Asterix & 8 & 0,20 & 70 & 12 & 0,28 & 52 \\
\hline Atlantic & 4 & 0,12 & 64 & 9 & 0,24 & 49 \\
\hline Markies & 6 & 0,18 & 66 & 10 & 0,34 & 50 \\
\hline Mondial & 6 & 0,20 & 72 & 14 & 0,41 & 56 \\
\hline
\end{tabular}

No período compreendido entre 42 e 62 DAP, ou seja, no início da fase de enchimento dos tubérculos, quando intensificou-se o acúmulo de $\mathrm{Mg}$ nas plantas (Figura 16F), ocorreram as maiores taxas diárias de absorção de $\mathrm{Mg}$ (Figura 17B), ocasionando o período de maiores demandas por $\mathrm{Mg}$ em todas as cultivares (Tabela 21). No entanto, a cultivar Markies concentrou maior parte da absorção nesse período, chegando a absorver mais de $60 \%$ de todo o $\mathrm{Mg}$ acumulado, o que é resultado da ocorrência precoce das maiores taxas diárias de absorção e das baixas taxas de absorção após esse período. Dos 48 DAP até o final do ciclo, a cultivar Asterix apresentou acúmulo de Mg superior ao observado na cultivar Ágata, porém, semelhante ao das cultivares Atlantic, Markies e Mondial no período 
de 48 a 69 DAP (Figura 16F). Embora, na ausência de diferenças significativas, constatou-se que a partir dos 69 DAP o acúmulo de Mg na cultivar Mondial foi maior que o observado na cultivar Asterix, o que deveu-se às maiores taxas de absorção ocorridas anteriormente a esse período (Figura 17B).

Tabela 21. Percentual de Mg acumulado pelas plantas em cada fase do desenvolvimento das cultivares de batata (valores obtidos nas equações ajustadas).

\begin{tabular}{lccccc}
\hline \multirow{2}{*}{ Cultivares } & \multicolumn{5}{c}{ Dias após o plantio/Fase da cultura } \\
\cline { 2 - 6 } & $\begin{array}{c}0-34 \\
\text { Crescimento vegetativo }\end{array}$ & $\begin{array}{c}35-41 \\
\text { Tuberização }\end{array}$ & $\begin{array}{c}42-62 \\
\text { Enchimento de tubérculos }\end{array}$ & $\begin{array}{c}61-97 \\
\text { Maturação }\end{array}$ \\
\hline \multirow{2}{*}{ Ágata } & 12 & 11 & 52 & 24 & 1 \\
Asterix & 17 & 10 & 45 & 26 & 2 \\
Atlantic & 18 & 12 & 49 & 20 & 1 \\
Markies & 11 & 13 & 61 & 15 & 0 \\
Mondial & 7 & 7 & 54 & 31 & 1 \\
\hline
\end{tabular}

De maneira geral, as quantidades máximas de $\mathrm{Mg}$ acumuladas pelas plantas de todas as cultivares aumentaram até próximo ao final do ciclo, atingindo, aos 97 DAP, as quantidades máximas acumuladas de 8, 12, 9, 10 e $14 \mathrm{~kg} \mathrm{ha}^{-1}$, nas cultivares Ágata, Asterix, Atlantic, Markies e Mondial, respectivamente (Figura 16F e Tabela 20). Yorinori (2003), na cultivar Atlantic, obteve acúmulos totais de $\mathrm{Mg}$ de $14,3 \mathrm{~kg} \mathrm{ha}^{-1}$ (safra das águas) e $6,9 \mathrm{~kg} \mathrm{ha}^{-1}$ (safra das secas) aos 111 e 69 DAP, respectivamente. As taxas de absorção diária de $\mathrm{Mg}$ foram crescentes desde a emergência até aos 49 a 56 DAP, no entanto, no período compreendido entre 64 e 72 DAP, quando as taxas de acúmulo de Mg nas plantas de batata já tinham diminuído, ocorreram as maiores taxas diárias de acúmulo de $\mathrm{Mg}$ nos tubérculos, indicando que em média, 15 dias após a ocorrência das máximas taxas diárias de absorção de $\mathrm{Mg}$, teve-se o período de maior translocação desse elemento dos outros órgãos da planta para os tubérculos.

\subsubsection{Enxofre}

$\mathrm{O}$ teor de $\mathrm{S}$ nos tubérculos-semente permaneceu relativamente constante durante o período de avaliação (Tabela 22). Nas raízes, hastes, folhas e tubérculos 
também não ocorreram grandes alterações no teor de $\mathrm{S}$ durante o ciclo, porém, nas últimas avaliações geralmente observou-se menores teores que os obtidos nas primeiras coletas. Embora com certas variações, os teores nas raízes, hastes e folhas apresentaram valores relativamente próximos, enquanto, os tubérculos tiveram teores inferiores aos obtidos nos demais órgãos. Os teores de S observados em todos os órgãos das plantas foram inferiores aos obtidos por Gargantini et al. (1963), porém, semelhantes aos observados por Paula et al. (1986).

Tabela 22. Teor de S em cada parte das plantas de cultivares de batata durante o ciclo da cultura.

\begin{tabular}{|c|c|c|c|c|c|c|c|c|c|c|c|c|c|}
\hline \multirow{2}{*}{ Cultivares } & \multicolumn{13}{|c|}{ Dias após o plantio } \\
\hline & 0 & 20 & 27 & 34 & 41 & 48 & 55 & 62 & 69 & 76 & 83 & 90 & 97 \\
\hline & \multicolumn{13}{|c|}{$\begin{array}{l}\mathrm{g} \mathrm{kg}^{-1} \\
\text { Tubérculos-semente }\end{array}$} \\
\hline Ágata & 1,1 & 1,5 & 1,8 & 1,7 & 1,6 & 1,5 & 1,6 & 1,4 & - & - & - & - & - \\
\hline Asterix & 1,0 & 1,4 & 1,8 & 1,8 & 1,5 & 1,4 & 1,6 & 1,2 & - & - & - & - & - \\
\hline Atlantic & 1,0 & 1,2 & 1,3 & 1,2 & 1,7 & 1,2 & 1,4 & 1,4 & - & - & - & - & - \\
\hline Markies & 1,2 & 1,3 & 1,5 & 1,0 & 1,2 & 0,8 & 0,9 & 0,9 & - & - & - & - & - \\
\hline \multirow[t]{2}{*}{ Mondial } & 1,1 & 1,3 & 1,9 & 1,3 & 1,7 & 1,5 & 1,6 & 1,4 & - & - & - & - & - \\
\hline & \multicolumn{13}{|c|}{ Raízes } \\
\hline Ágata & - & 3,2 & 2,6 & 2,5 & 2,2 & 2,4 & 2,4 & 3,2 & 3,4 & 3,4 & 2,4 & 1,9 & 2,1 \\
\hline Asterix & - & 2,9 & 2,0 & 2,1 & 1,7 & 2,0 & 2,1 & 2,5 & 2,7 & 3,0 & 2,4 & 2,2 & 2,0 \\
\hline Atlantic & - & 2,9 & 1,9 & 1,6 & 1,6 & 1,7 & 1,7 & 2,0 & 2,6 & 2,5 & 2,2 & 1,7 & 1,6 \\
\hline Markies & - & 3,3 & 2,5 & 2,2 & 2,2 & 2,0 & 2,3 & 3,0 & 3,7 & 3,4 & 3,1 & 2,4 & 2,4 \\
\hline Mondial & - & 2,3 & 1,9 & 2,1 & 2,0 & 2,1 & 2,3 & 2,6 & 3,0 & 3,0 & 2,5 & 1,8 & 1,8 \\
\hline & \multicolumn{13}{|c|}{ Hastes } \\
\hline Ágata & - & 1,8 & 2,0 & 2,0 & 2,1 & 2,2 & 3,1 & 3,4 & 3,2 & 3,1 & 2,2 & 1,6 & 1,6 \\
\hline Asterix & - & 2,1 & 2,1 & 2,3 & 2,1 & 2,2 & 2,6 & 3,0 & 2,5 & 2,2 & 1,8 & 1,1 & 0,8 \\
\hline Atlantic & - & 2,2 & 1,9 & 2,4 & 1,8 & 1,8 & 1,9 & 1,7 & 1,4 & 1,2 & 1,5 & 1,0 & 1,9 \\
\hline Markies & - & 2,4 & 1,9 & 2,1 & 1,9 & 1,8 & 2,2 & 2,4 & 1,7 & 1,3 & 1,2 & 1,0 & 0,9 \\
\hline Mondial & - & 1,5 & 1,6 & 1,9 & 1,7 & 1,7 & 2,4 & 2,9 & 2,5 & 2,5 & 2,5 & 2,1 & 2,0 \\
\hline & \multicolumn{13}{|c|}{ Folhas } \\
\hline Ágata & - & 2,2 & 2,4 & 2,2 & 2,1 & 2,0 & 2,1 & 2,1 & 1,9 & 1,9 & 2,1 & 2,4 & 2,3 \\
\hline Asterix & - & 2,1 & 2,6 & 2,3 & 1,8 & 1,9 & 1,8 & 2,0 & 1,9 & 1,7 & 2,0 & 2,0 & 2,0 \\
\hline Atlantic & - & 2,3 & 2,8 & 2,3 & 2,0 & 2,2 & 2,1 & 2,0 & 2,0 & 2,1 & 2,2 & 2,2 & 2,6 \\
\hline Markies & - & 2,3 & 3,0 & 2,6 & 2,2 & 2,0 & 2,0 & 2,3 & 1,9 & 1,6 & 2,0 & 2,1 & 1,9 \\
\hline Mondial & - & 2,4 & 2,7 & 2,2 & 2,1 & 2,1 & 2,4 & 2,2 & 2,3 & 2,1 & 2,1 & 2,3 & 2,6 \\
\hline & \multicolumn{13}{|c|}{ Tubérculos } \\
\hline Ágata & - & - & - & 1,2 & 1,4 & 1,1 & 1,0 & 1,0 & 1,0 & 1,1 & 1,4 & 1,3 & 0,9 \\
\hline Asterix & - & - & - & 1,1 & 1,3 & 1,0 & 0,9 & 0,8 & 0,7 & 0,8 & 1,1 & 1,1 & 0,9 \\
\hline Atlantic & - & - & - & 1,1 & 1,4 & 1,0 & 1,0 & 1,1 & 0,8 & 1,1 & 1,4 & 1,4 & 1,3 \\
\hline Markies & - & - & - & 1,5 & 1,5 & 1,1 & 1,1 & 1,1 & 1,0 & 1,3 & 1,4 & 1,4 & 0,8 \\
\hline Mondial & - & - & - & 0,8 & 1,1 & 0,8 & 0,8 & 0,8 & 0,9 & 0,9 & 1,3 & 1,1 & 0,7 \\
\hline
\end{tabular}


Com relação às quantidades de $\mathrm{S}$ presente nos tubérculos-semente, observa-se que houve diminuição a partir do plantio até aos 62 DAP, em todas as cultivares estudadas (Figura 18A). Constata-se também, que não ocorreram diferenças entre as cultivares para esta variável.

Os acúmulos de $\mathrm{S}$ nas raízes, aumentaram de maneira diferente entre as cultivares a partir da emergência até aos 58, 58, 60, 66 e 67 DAP, nas cultivares Ágata, Asterix, Atlantic, Markies e Mondial, com os acúmulos máximos de 0,037, 0,057, 0,043, 0,052 e $0,049 \mathrm{~kg} \mathrm{ha}^{-1}$, respectivamente (Figura 18B). De maneira geral, as raízes da cultivar Asterix apresentaram maiores acúmulos de $\mathrm{S}$ que o observado em todas as demais cultivares, da emergência até 48 DAP. A cultivar Mondial foi a mais tardia em acumular $\mathrm{S}$ em suas raízes, enquanto, a cultivar Ágata apresentou o menor acúmulo de $\mathrm{S}$ na fase final do ciclo. Yorinori (2003) observou acúmulo máximo de $\mathrm{S}$ nas raízes da cultivar Atlantic de $0,07 \mathrm{~kg} \mathrm{ha}^{-1}$ na safra das águas (67 DAP) e o mesmo valor na safra das secas (47 DAP), ou seja, superiores aos observados no presente experimento para a mesma cultivar.

As quantidades de $\mathrm{S}$ acumuladas nas hastes foram semelhante entre as cultivares da emergência até aos 34 DAP e, a partir dos 35 DAP os acúmulos de S pelas hastes intensificaram-se de maneira diferente entre as cultivares (Figura 18C). Entre os 48 e 69 DAP, a cultivar Asterix apresentou acúmulo de $\mathrm{S}$ em suas hastes superior ao observado nas cultivares Ágata, Atlantic e Markies. Os maiores acúmulos de $\mathrm{S}$ nas hastes foram observados na cultivar Mondial, a partir dos 69 DAP até o final do ciclo, o que está relacionado com o maior acúmulo de MS observado nas hastes dessa cultivar (Figura 5C). Porém, na última avaliação, todas as demais cultivares apresentaram acúmulo semelhante de $\mathrm{S}$ em suas hastes, provavelmente em função dos menores teores de S nas hastes da cultivar Asterix (Tabela 22), uma vez que, a MS de hastes dessa cultivar foi maior que a obtida nas cultivares Atlantic, Markies e Ágata. As quantidades máximas de $\mathrm{S}$ acumuladas nas hastes foram estimadas em 0,57, 0,85, 0,34, 0,35 e 1,42 $\mathrm{kg} \mathrm{ha}^{-1}$ e, ocorreram aos 73, 69, 61, 67 e 80 DAP, respectivamente, para as cultivares Ágata, Asterix, Atlantic, Markies e Mondial. 

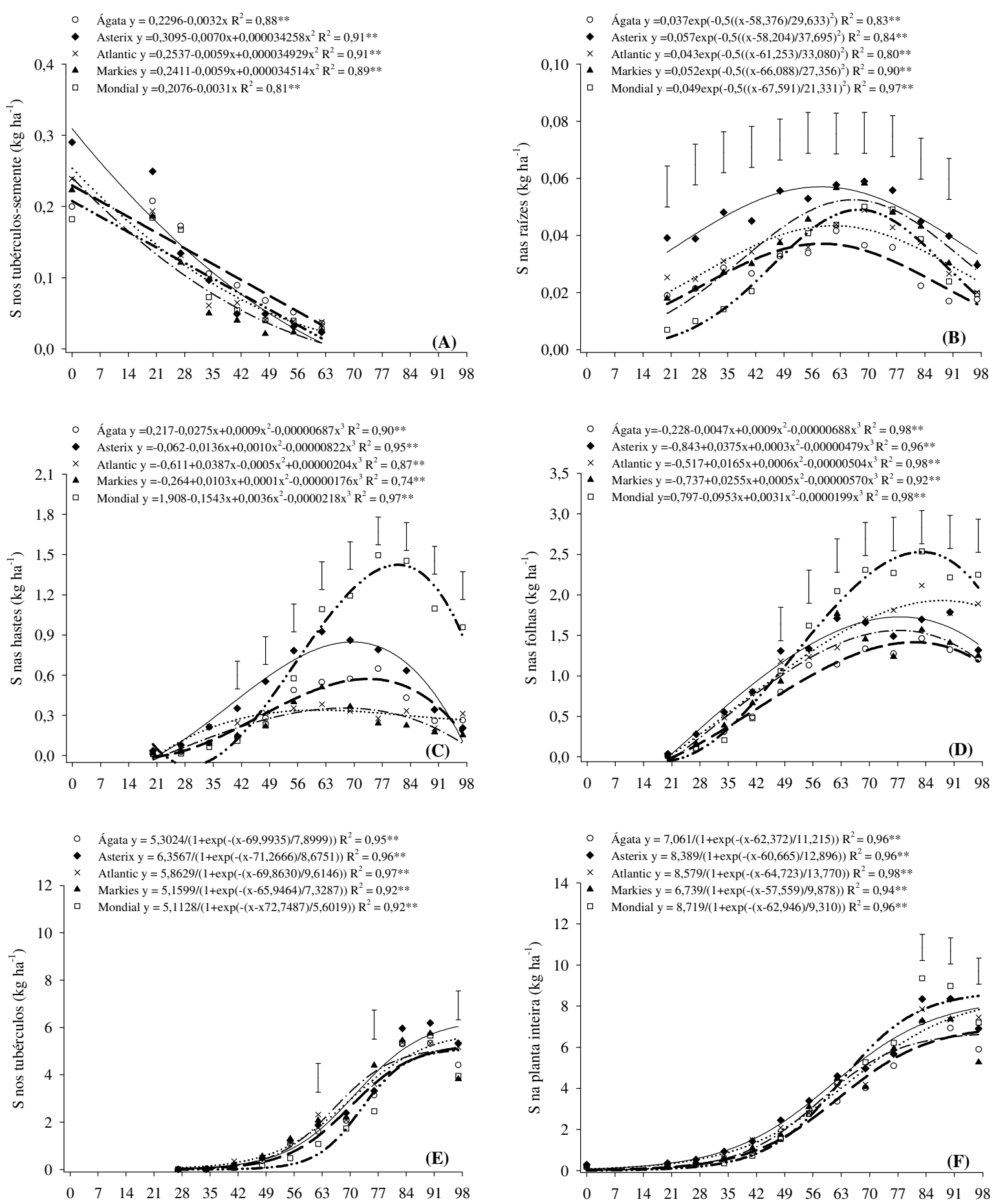

Dias após o plantio

Figura 18. Quantidade total de S nos tubérculos-semente (A), raízes (B), hastes (C), folhas (D), tubérculos $(\mathrm{E})$ e na planta inteira $(\mathrm{F})$ de cultivares de batata ao longo do ciclo. ** significativo a $1 \%$ de probabilidade pelo teste $\mathrm{F}$. Barras verticais indicam o valor de DMS pelo teste Tukey a $5 \%$ de probabilidade. 
Nas folhas, as quantidades de $\mathrm{S}$ acumuladas foram semelhantes entre as cultivares até aos 41 DAP e, a partir dos 48 DAP, os acúmulos de $\mathrm{S}$ nas folhas aumentaram alcançando as quantidades máximas estimadas de 1,41, 1,73, 1,93, 1,56 e 2,53 $\mathrm{kg} \mathrm{ha}^{-1}$, aos 81 , 77, 88, 77 e 83 DAP nas cultivares Ágata, Asterix, Atlantic, Markies e Mondial, respectivamente (Figura 18D). Dos 69 aos 83 DAP, os maiores acúmulos de $\mathrm{S}$ foram obtidos nas folhas da cultivar Mondial, no entanto, na última avaliação a cultivar Atlantic apresentou acúmulo de $\mathrm{S}$ semelhante à Mondial e, ambas tiveram acúmulo de $\mathrm{S}$ superior ao das demais cultivares. $\mathrm{O}$ maior acúmulo de $\mathrm{S}$ nas folhas da cultivar Atlantic em comparação à Asterix, Markies e Ágata na última avaliação, ocorreu em função dos maiores teores de $\mathrm{S}$ observados nas folhas da cultivar Atlantic nesse período (Tabela 22), pois, a quantidade de MS foliar foi semelhante entre essas cultivares (Figura 5D).

Houve acúmulo contínuo de $\mathrm{S}$ nos tubérculos do início da tuberização até o final do ciclo, quando as cultivares Ágata, Asterix, Atlantic, Markies e Mondial, obtiveram acúmulos máximos estimados de 5, 6, 5, 5 e $5 \mathrm{~kg} \mathrm{ha}^{-1}$, respectivamente (Figura 18E). Até aos $55 \mathrm{DAP}$, a quantidade de $\mathrm{S}$ acumulada nos tubérculos foi semelhante entre as cultivares, no entanto, aos 62 e 76 DAP, o acúmulo de S nos tubérculos das cultivar Mondial foi inferior aos observados nas cultivares Atlantic e Markies, respectivamente. Na última avaliação os maiores acúmulos ocorreram na cultivar Asterix e o menor na cultivar Markies.

No final do ciclo, aproximadamente $63 \%$ do total de $\mathrm{S}$ acumulado pelas cultivares Atlantic e Mondial estava presente nos tubérculos, nas cultivares Ágata e Markies esse valor foi de $71 \%$, enquanto, na cultivar Asterix o valor foi mais alto e próximo de $75 \%$. Paula et al. (1986), em estudo sobre a produção de MS e absorção de macronutrientes por cultivares de batata, observou que do total de $\mathrm{S}$ extraído pelas plantas da cultivar Mantiqueira, em torno de 63\% (não adubada com NPK) e 79\% (adubada com NPK) foram acumulados nos tubérculos. A época de maior taxa de acúmulo de $\mathrm{S}$ nos tubérculos ocorreu entre 66 e 72 DAP quando as cultivares Ágata, Asterix, Atlantic, Markies e Mondial atingiram taxas de acúmulos de 0,16, 0,18, 0,15, 0,17 e 0,23 $\mathrm{kg} \mathrm{ha}^{-1} \mathrm{dia}^{-1}$, respectivamente (Figura 19A e Tabela 23). 

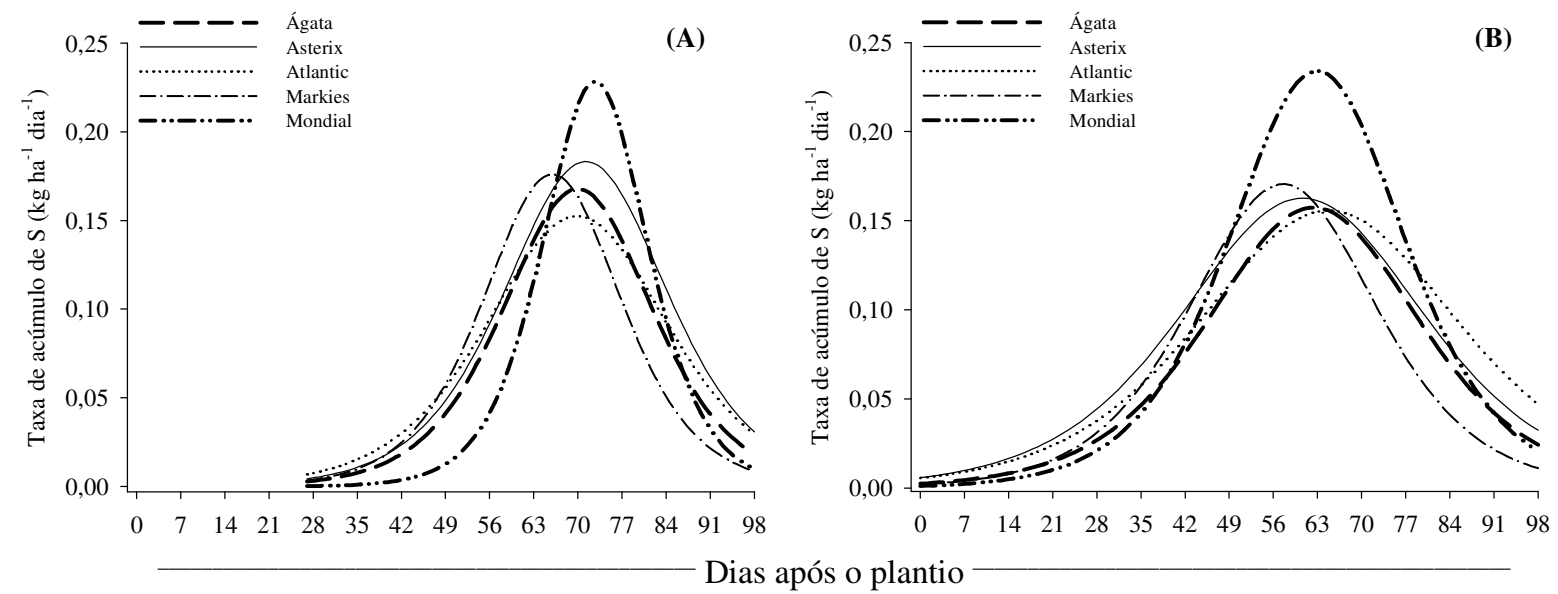

Figura 19. Taxa de acúmulo de $\mathrm{S}$ nos tubérculos (A) e nas plantas (B) de cultivares de batata ao longo do ciclo.

Tabela 23. Quantidade máxima de $S$ acumulada, taxa diária máxima de acúmulo e época de maior taxa de acúmulo de $\mathrm{S}$ nos tubérculos e nas plantas de cultivares de batata.

\begin{tabular}{|c|c|c|c|c|c|c|}
\hline Cultivares & $\begin{array}{l}\text { Acúmulo } \\
\text { máximo no } \\
\text { tubérculo }\end{array}$ & $\begin{array}{c}\text { Taxa } \\
\text { máxima de } \\
\text { acúmulo no } \\
\text { tubérculo }\end{array}$ & $\begin{array}{c}\text { Época de } \\
\text { maior taxa de } \\
\text { acúmulo no } \\
\text { tubérculo }\end{array}$ & $\begin{array}{l}\text { Acúmulo } \\
\text { máximo na } \\
\text { planta }\end{array}$ & $\begin{array}{c}\text { Taxa } \\
\text { máxima de } \\
\text { acúmulo na } \\
\text { planta }\end{array}$ & $\begin{array}{c}\text { Época de } \\
\text { maior taxa } \\
\text { de acúmulo } \\
\text { na planta }\end{array}$ \\
\hline & $\mathrm{kg} \mathrm{ha}^{-1}$ & $\mathrm{~kg} \mathrm{ha}^{-1} \mathrm{dia}^{-1}$ & DAP & $\mathrm{kg} \mathrm{ha}^{-1}$ & $\mathrm{~kg} \mathrm{ha}^{-1} \mathrm{dia}^{-1}$ & DAP \\
\hline Ágata & 5 & 0,16 & 70 & 7 & 0,15 & 62 \\
\hline Asterix & 6 & 0,18 & 71 & 8 & 0,16 & 60 \\
\hline Atlantic & 5 & 0,15 & 70 & 8 & 0,15 & 64 \\
\hline Markies & 5 & 0,17 & 66 & 7 & 0,17 & 58 \\
\hline Mondial & 5 & 0,23 & 72 & 8 & 0,23 & 62 \\
\hline
\end{tabular}

As quantidades totais acumuladas de $\mathrm{S}$ nas plantas inteiras, não diferiram entre as cultivares desde o plantio até aos 76 DAP, atingindo no final do ciclo as quantidades máximas estimadas de 7, 8, 8, 7 e $8 \mathrm{~kg} \mathrm{ha}^{-1}$ nas cultivares Ágata, Asterix, Atlantic, Markies e Mondial, respectivamente (Figura 18F). Na fase de crescimento vegetativo houve baixa absorção em $\mathrm{S}$ em todas cultivares, uma vez que, as taxas diárias de absorção foram baixas e, todas as cultivares absorveram menos de $13 \%$ do total de $\mathrm{S}$ extraído, nesse período (Figura 9B e Tabela 24). A época de maior exigência por $\mathrm{S}$ ocorreu durante o enchimento de tubérculos, sendo que no início dessa fase (42-62 DAP), a cultivar Markies absorveu ao redor de $46 \%$ do total acumulado, enquanto, as demais cultivares apresentaram as maiores 
porcentagens de absorção na fase final desse estádio (Tabela 24). A absorção precoce de $\mathrm{S}$ observada na cultivar Markies, foi devido à ocorrência das maiores taxas diárias de absorção mais precocemente e menores taxas na fase final de enchimento de tubérculos (Figura 19B).

Tabela 24. Percentual de $\mathrm{S}$ acumulado pelas plantas em cada fase do desenvolvimento das cultivares de batata (valores obtidos nas equações ajustadas).

\begin{tabular}{lccccc}
\hline \multirow{5}{*}{ Cultivares } & \multicolumn{5}{c}{ Dias após o plantio/Fase da cultura } \\
\cline { 2 - 6 } & $\begin{array}{c}0-34 \\
\text { Crescimento vegetativo }\end{array}$ & $\begin{array}{c}34-41 \\
\text { Tuberização }\end{array}$ & $\begin{array}{c}42-62 \\
\text { Enchimento de tubérculos }\end{array}$ & $\begin{array}{c}91-97 \\
\text { Maturação }\end{array}$ \\
\hline \multirow{2}{*}{ Ágata } & 8 & 6 & 38 & 45 & 3 \\
Asterix & 12 & 7 & 37 & 40 & 4 \\
Atlantic & 11 & 6 & 34 & 44 & 5 \\
Markies & 9 & 7 & 46 & 36 & 2 \\
Mondial & 4 & 4 & 41 & 48 & 3 \\
\hline
\end{tabular}

Dos 83 aos 90 DAP a cultivar Mondial apresentou maior acúmulo de $\mathrm{S}$ que as cultivares Atlantic, Markies e Ágata, no entanto, aos 97 DAP as quantidades acumuladas de S nas cultivares Mondial, Asterix e Atlantic foram semelhantes e superiores as das cultivares Ágata e Markies (Figura 18F). Yorinori (2003) em estudo sobre o crescimento e o acúmulo de nutrientes pela batateira, cultivar Atlantic, obteve acúmulos totais de $S$ de 10,8 $\mathrm{kg} \mathrm{ha}^{-1}$ (safra das águas) e 6,7 $\mathrm{kg} \mathrm{ha}^{-1}$ (safra das secas) aos 111 e 87 DAP, respectivamente, ou seja, na safra das águas o acúmulo foi superior e na safra das secas inferior ao observado no presente experimento. O período de máxima taxa de absorção foi desde 48 DAP até os 76 DAP, ou seja, desde o início até próximo ao final da fase de enchimento de tubérculos (Figura 19B). Embora durante todo este período a demanda de $\mathrm{S}$ tenha sido relativamente alta, esta acentuou-se ainda mais entre 58 e 64 DAP, quando ocorreu início do crescimento exponencial dos tubérculos (Figuras 4C, 4D e 5E), época em que as cultivares Ágata, Asterix, Atlantic, Markies e Mondial absorveram aproximadamente $0,15,0,16,0,15,0,17$ e 0,23 $\mathrm{kg} \mathrm{ha}^{-1} \mathrm{dia}^{-1}$, respectivamente.

As taxas máximas diárias de absorção de $\mathrm{S}$ foram muito próximas das taxas máximas de acúmulo de $\mathrm{S}$ nos tubérculos e ocorreram em média 8 dias antes (Figura 19 e Tabela 23). Isso demonstra que semelhante ao que ocorreu para o $\mathrm{P}$, o $\mathrm{S}$ também sofre intensa translocação para os tubérculos. Gargantini et al. (1963) também observou 
comportamento semelhante a esse com o S sofrendo intensa translocação para os tubérculos da batateira, cultivar Bintje.

Ainda com base nas taxas diárias de absorção, observa-se se que a absorção diária de Ca chega a ser maior que a de $\mathrm{P}$ e S, no entanto, quando observa-se a taxa de acúmulo desses elementos nos tubérculos, fica claro a maior mobilidade dos elementos $\mathrm{P}$ e $\mathrm{S}$ na planta, uma vez que o acúmulo diário de $\mathrm{P}$ e $\mathrm{S}$ nos tubérculos é superior ao de $\mathrm{Ca}$, exceção feita apenas para as cultivares Asterix e Mondial que apresentaram taxa de acúmulo de Ca nos tubérculos superior a de S (Tabelas 11, 17 e 23).

\subsection{Marcha de absorção de micronutrientes}

\subsubsection{Boro}

O teor de B nos tubérculos-semente teve comportamento semelhante ao do $\mathrm{Ca}$, com aumento constante a partir do plantio até os 55 DAP (Tabelas 16 e 25). Nas raízes, hastes e folhas, os maiores teores de $\mathrm{B}$ foram observados da emergência até em torno dos 55 DAP, com diminuição após esse período. Embora com certas alterações, observa-se que o teor de B nos tubérculos decresceu em função do tempo a partir do início da tuberização. No final do ciclo os maiores teores de B ocorreram nas folhas, seguidas das raízes, hastes e tubérculos.

As quantidades de B presentes nos tubérculos-semente permaneceram relativamente constantes do plantio até aos 55 DAP (Figura 20A). Apesar da redução na MS dos tubérculos-semente (Figura 5A) do plantio até a última avaliação, as quantidades de B nesse período não foram muito alteradas, devido aos aumentos nos teores de $\mathrm{B}$ dos tubérculossemente (Tabela 25). No momento do plantio os tubérculos-semente da cultivar Ágata continham mais B em comparação à Markies, porém, aos 20 DAP apenas a cultivar Asterix apresentou maiores quantidades de $\mathrm{B}$ nos tubérculos-semente em relação à Markies e Atlantic. Já aos 27 DAP constatou-se diferenças apenas entre Ágata e Markies quanto a essa variável. Foram observadas pequenas reduções na quantidade de $\mathrm{B}$ dos tubérculos-semente com o decorrer do ciclo, principalmente, devido as características desse elemento na planta, uma vez que o B atua interligando moléculas de polissacarídeo da parede celular e também está associado com as pectinas (EPSTEIN; BLOOM, 2004). Isso, além de outros fatores fazem 
com que o B seja praticamente imóvel nas plantas, sendo translocado, principalmente, através do xilema e apresentando mobilidade muito limitada no floema (RAVEN, 1980).

Tabela 25. Teor de B em cada parte das plantas de cultivares de batata durante o ciclo da cultura.

\begin{tabular}{|c|c|c|c|c|c|c|c|c|c|c|c|c|c|}
\hline \multirow{2}{*}{ Cultivares } & \multicolumn{13}{|c|}{ Dias após o plantio } \\
\hline & 0 & 20 & 27 & 34 & 41 & 48 & 55 & 62 & 69 & 76 & 83 & 90 & 97 \\
\hline & \multirow{2}{*}{\multicolumn{13}{|c|}{$\begin{array}{l}\mathrm{mg} \mathrm{kg}^{-1} \\
\text { Tubérculos-semente }\end{array}$}} \\
\hline & & & & & & & & & & & & & \\
\hline Ágata & 17 & 23 & 40 & 46 & 48 & 71 & 92 & 37 & - & - & - & - & - \\
\hline Asterix & 10 & 21 & 51 & 58 & 74 & 76 & 93 & 26 & - & - & - & - & - \\
\hline Atlantic & 8 & 11 & 32 & 44 & 73 & 74 & 97 & 44 & - & - & - & - & - \\
\hline Markies & 8 & 17 & 32 & 41 & 71 & 81 & 88 & 35 & - & - & - & - & - \\
\hline \multirow[t]{2}{*}{ Mondial } & 13 & 19 & 34 & 44 & 70 & 75 & 97 & 53 & - & - & - & - & - \\
\hline & \multicolumn{13}{|c|}{ Raízes } \\
\hline Ágata & - & 56 & 85 & 64 & 83 & 77 & 53 & 41 & 61 & 35 & 29 & 28 & 27 \\
\hline Asterix & - & 56 & 58 & 65 & 64 & 61 & 50 & 45 & 53 & 35 & 24 & 18 & 27 \\
\hline Atlantic & - & 64 & 77 & 55 & 73 & 72 & 49 & 46 & 55 & 37 & 24 & 25 & 25 \\
\hline Markies & - & 59 & 59 & 55 & 72 & 66 & 47 & 34 & 49 & 36 & 24 & 28 & 25 \\
\hline Mondial & - & 92. & 87 & 61 & 78 & 70 & 48 & 40 & 45 & 36 & 25 & 27 & 25 \\
\hline & \multicolumn{13}{|c|}{ Hastes } \\
\hline Ágata & - & 64 & 56 & 38 & 49 & 36 & 27 & 27 & 25 & 28 & 21 & 21 & 25 \\
\hline Asterix & - & 51 & 50 & 34 & 35 & 33 & 31 & 27 & 24 & 26 & 16 & 18 & 22 \\
\hline Atlantic & - & 63 & 51 & 34 & 35 & 35 & 29 & 27 & 23 & 34 & 21 & 24 & 25 \\
\hline Markies & - & 47 & 59 & 38 & 43 & 42 & 28 & 24 & 27 & 34 & 21 & 20 & 23 \\
\hline Mondial & - & 56 & 56 & 43 & 49 & 41 & 23 & 19 & 21 & 18 & 16 & 16 & 19 \\
\hline & \multicolumn{13}{|c|}{ Folhas } \\
\hline Ágata & - & 70 & 44 & 34 & 48 & 48 & 39 & 26 & 31 & 36 & 21 & 23 & 34 \\
\hline Asterix & - & 55 & 36 & 30 & 43 & 38 & 41 & 27 & 33 & 40 & 26 & 28 & 39 \\
\hline Atlantic & - & 62 & 46 & 42 & 43 & 41 & 42 & 33 & 30 & 36 & 20 & 23 & 35 \\
\hline Markies & - & 64 & 54 & 29 & 43 & 47 & 41 & 25 & 31 & 39 & 24 & 26 & 35 \\
\hline Mondial & . & 66 & 42 & 40 & 46 & 51 & 47 & 27 & 34 & 39 & 27 & 33 & 41 \\
\hline & \multicolumn{13}{|c|}{ Tubérculos } \\
\hline Ágata & - & - & - & 23 & 18 & 27 & 18 & 12 & 13 & 12 & 7 & 7 & 7 \\
\hline Asterix & - & - & - & 26 & 19 & 29 & 17 & 8 & 10 & 9 & 6 & 6 & 6 \\
\hline Atlantic & - & - & - & 22 & 17 & 19 & 14 & 7 & 6 & 7 & 5 & 5 & 6 \\
\hline Markies & - & - & - & 30 & 16 & 16 & 13 & 7 & 7 & 7 & 4 & 5 & 5 \\
\hline Mondial & - & - & - & 40 & 17 & 25 & 17 & 7 & 8 & 11 & 6 & 6 & 6 \\
\hline
\end{tabular}



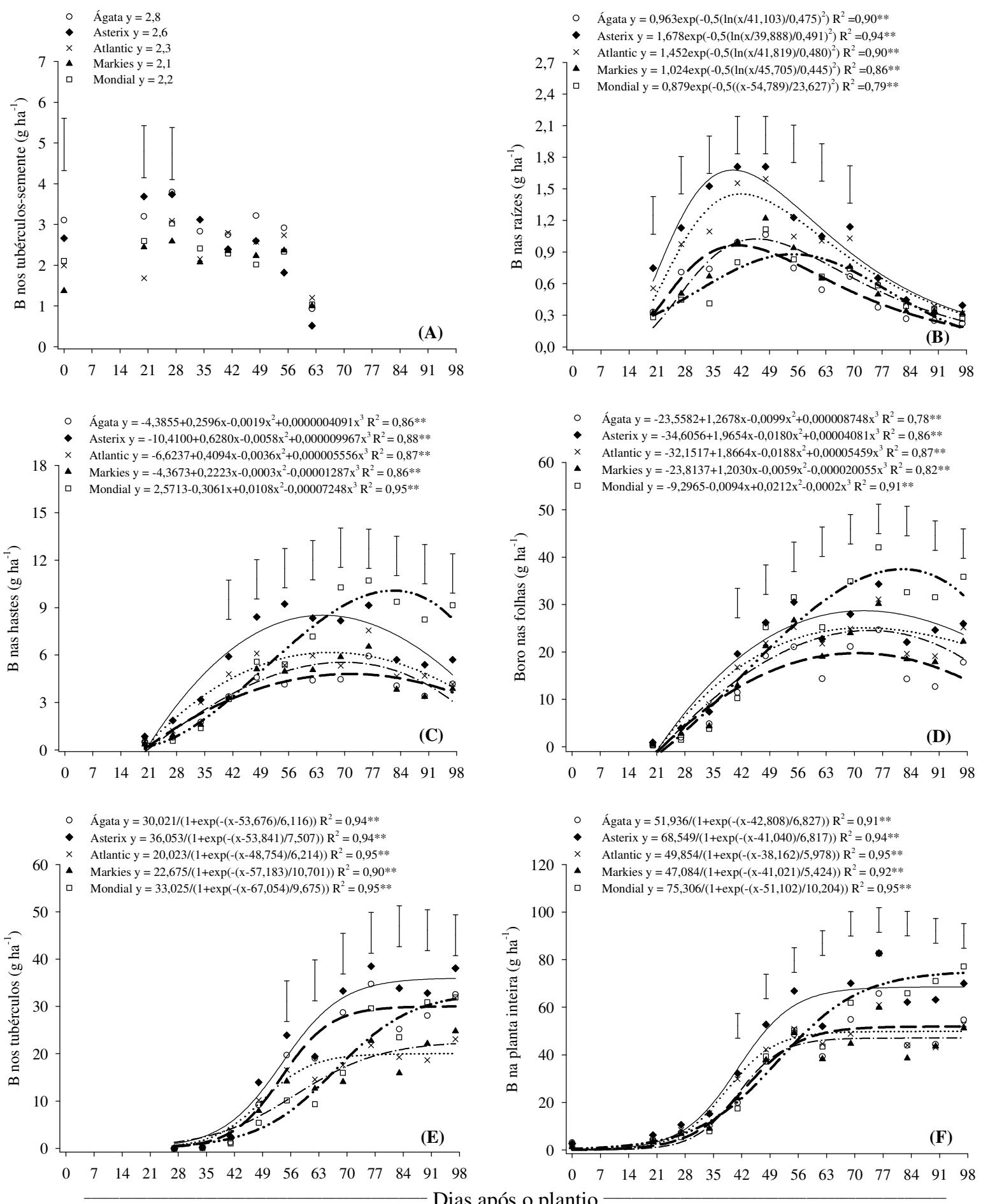

Figura 20. Quantidade de B nos tubérculos-semente (A), raízes (B), hastes (C), folhas (D), tubérculos $(\mathrm{E})$ e na planta inteira $(\mathrm{F})$ de cultivares de batata ao longo do ciclo. ** significativo a $1 \%$ de probabilidade pelo teste F. Barras verticais indicam o valor de DMS pelo teste Tukey a $5 \%$ de probabilidade. 
Os acúmulos de $\mathrm{B}$ nas raízes aumentaram desde a emergência, atingindo as quantidades máximas estimadas de 0,96, 1,68, 1,45, 1,04 e 0,88 $\mathrm{g} \mathrm{ha}^{-1}$ aos 41, 40, 41, 45 e 54 DAP para as cultivares Ágata, Asterix, Atlantic, Markies, e Mondial, respectivamente (Figura 20B). Embora no início do ciclo a cultivar Atlantic tenha acumulado $\mathrm{B}$ em quantidades semelhantes àquelas observadas nas cultivares Ágata e Markies, de maneiral geral, as raízes das cultivares Asterix e Atlantic apresentaram os maiores acúmulos de B durante a fase inicial de desenvolvimento, comportamento esse semelhante ao obtido para a MS radicular (Figura 5B). No início da fase de enchimento de tubérculos, quando todas as cultivares apresentaram reduções na quantidade de B acumulada nas raízes, o acúmulo de B nas raízes da cultivar Mondial continuou aumentando até próximo aos 54 DAP. No entanto, a partir dos 76 DAP, o acúmulo de B nas raízes de todas as cultivares diminuiu de forma semelhante até o final do ciclo. Yorinori (2003) observou acúmulo máximo de B nas raízes da cultivar Atlantic de $0,86 \mathrm{~g} \mathrm{ha}^{-1}$ na safra das águas (67 DAP) e $0,88 \mathrm{~g} \mathrm{ha}^{-1}$ na safra das secas (40 DAP), ou seja, inferiores aos observados em todas cultivares estudadas.

As quantidades de B acumuladas nas hastes foram semelhante entre as cultivares, até aos 34 DAP, sendo que depois disso os acúmulos de B nas hastes aumentaram de forma diferente entre as cultivares (Figura 20C). Entre os 41 e 55 DAP, o acúmulo de B nas hastes da cultivar Asterix foi superior ao observado em todas as cultivares, com exceção da cultivar Atlantic aos 41 e 48 DAP que teve acúmulo semelhante. No entanto, a partir dos 69 DAP, houve redução do acúmulo de $\mathrm{B}$ nas hastes da cultivar Asterix, a qual apresentou acúmulo semelhante ao das cultivares Ágata, Atlantic e Markies a partir dos 83 DAP. Essa redução do acúmulo de $\mathrm{B}$ nas hastes da cultivar Asterix, nesse período, foi devido aos teores inferiores aos observados nas cultivares Ágata, Atlantic e Markies (Tabela 25). O acúmulo de B nas hastes da cultivar Mondial foi pequeno no início do ciclo, porém, atingiu valores superiores as demais cultivares nas últimas três avaliações, o que está relacionado com a maior acumulação tardia de MS nas hastes dessa cultivar (Figura 5C). As quantidades máximas de B acumuladas nas hastes foram estimadas em 4,80, 8,52, 6,17, 5,54 e 10,10 $\mathrm{g} \mathrm{ha}^{-1} \mathrm{e}$, ocorreram aos 71, 64, 66, 69 e 82 DAP, respectivamente, para as cultivares Ágata, Asterix, Atlantic, Markies e Mondial.

Nas folhas, os acúmulos de B foram semelhantes entre as cultivares até aos 34 DAP (Figura 20D). Os valores máximos estimados de acúmulo foram 19,7, 28,7, 25,1, 
24,5 e 37,5 $\mathrm{g} \mathrm{ha}^{-1}$, aos 70, 72, 72, 73 e 82 DAP nas cultivares Ágata, Asterix, Atlantic, Markies e Mondial, respectivamente (Figura 20D). A partir dos 69 DAP até o final do ciclo as folhas da cultivar Mondial apresentaram os maiores acúmulos de $\mathrm{B}$ em relação às demais, o que está relacionado com a maior MS foliar apresentada por essa cultivar essa época (Figura 5D). Embora não tenha apresentado diferença significativa, de maneira geral, do início da fase de enchimento de tubérculos (42 DAP) até o final do ciclo os menores acúmulos foliares de B foram observados na cultivar Ágata, a qual também teve menor acúmulo de MS que as demais (Figura 5D).

Os dados referentes aos acúmulos de B nos tubérculos foram ajustados a modelos sigmóides de regressão (Figura 20E). Nos tubérculos os acúmulos de B foram pequenos e semelhantes durante a fase de tuberização (35 a 41 DAP), porém, com o início do enchimento de tubérculos, ocorreram aumentos nas quantidades de B acumuladas nos mesmos, em todas as cultivares estudadas. No período compreendido entre 48 e 69 DAP, o acúmulo de B nos tubérculos da cultivar Asterix foi superior ao obtido na cultivar Mondial. No entanto, devido ao aumento crescente do acúmulo de B nos tubérculos da cultivar Mondial na fase final do ciclo, ambas cultivares tiveram acúmulo semelhante e superior que o observado nas cultivares Markies e Atlantic. Embora a cultivar Ágata tenha apresentado MS de tubérculos inferior àquela obtida nas cultivares Asterix e Mondial (Figura 5E), o acúmulo de B nestas cultivares foi semelhante no final do ciclo, o que ocorreu principalmente devido aos maiores teores de B observados nos tubérculos da cultivar Ágata, durante a fase final (Tabela 25). No final do ciclo, os acúmulos máximos estimados de $\mathrm{B}$ nos tubérculos foram de 30, 36, 20, 22 e $31 \mathrm{~g} \mathrm{ha}^{-1}$ nas cultivares Ágata, Asterix, Atlantic, Markies e Mondial, respectivamente (Figura 20E). Nesse período, a quantidade de B acumulada nos tubérculos representou entre 53\% e 58\% do B acumulado pelas cultivares Asterix e Ágata, cerca de 47\% na cultivar Markies e aproximadamente $42 \%$ a $47 \%$ nas cultivares Mondial e Atlantic (Figura 20E e Tabela 26).

Dos 49 aos 67 DAP, verificaram-se as maiores taxas de acúmulos de B nos tubérculos, quando as cultivares Ágata, Asterix, Atlantic, Markies e Mondial atingiram as taxas máximas de acúmulo diário de 1,22, 1,20,0,80,0,53 e 0,85 $\mathrm{g} \mathrm{ha}^{-1} \mathrm{dia}^{-1}$, respectivamente (Figura 21A e Tabela 26). As cultivares Asterix, Ágata e Atlantic foram as mais precoces em acumular esse elemento nos tubérculos alcançando as taxas máximas diárias de acúmulo aos 
49, 54 e 54 DAP, respectivamente. Já as cultivares Markies e Mondial apresentaram as maiores taxas de acúmulo de $\mathrm{B}$ nos tubérculos mais no final do ciclo, fato que proporcionou acúmulo de B crescente até a última coleta (Figura 21A e Figura 20E).
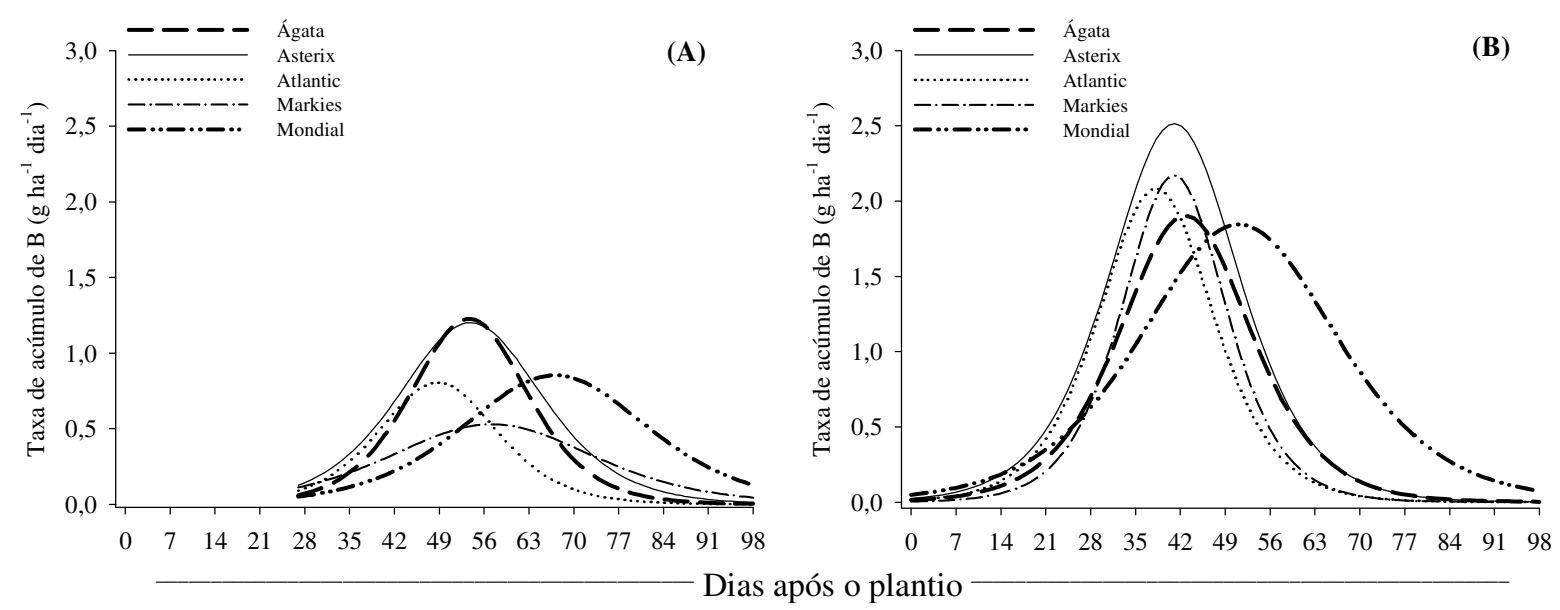

Figura 21. Taxa de acúmulo de B nos tubérculos (A) e nas plantas (B) de cultivares de batata ao longo do ciclo.

Tabela 26. Quantidade máxima de B acumulada, taxa diária máxima de acúmulo e época de maior taxa de acúmulo de $\mathrm{B}$ nos tubérculos e nas plantas de cultivares de batata.

\begin{tabular}{lcccccc}
\hline Cultivares & $\begin{array}{c}\text { Acúmulo } \\
\text { máximo no } \\
\text { tubérculo }\end{array}$ & $\begin{array}{c}\text { Taxa } \\
\text { máxima de } \\
\text { acúmulo no } \\
\text { tubérculo }\end{array}$ & $\begin{array}{c}\text { Época de } \\
\text { maior taxa de } \\
\text { acúmulo no } \\
\text { tubérculo }\end{array}$ & $\begin{array}{c}\text { Acúmulo } \\
\text { máximo na } \\
\text { planta }\end{array}$ & $\begin{array}{c}\text { Taxa } \\
\text { máxima de } \\
\text { acúmulo na } \\
\text { planta }\end{array}$ & $\begin{array}{c}\text { Época de } \\
\text { maior taxa } \\
\text { de acúmulo } \\
\text { na planta }\end{array}$ \\
\hline Ágata & $\mathrm{g} \mathrm{ha}^{-1}$ & $\mathrm{~g} \mathrm{ha}^{-1} \mathrm{dia}^{-1}$ & $\mathrm{DAP}$ & $\mathrm{g} \mathrm{ha}^{-1}$ & $\mathrm{~g} \mathrm{ha}^{-1} \mathrm{dia}^{-1}$ & $\mathrm{DAP}$ \\
Asterix & 30 & 1,22 & 54 & 52 & 1,90 & 43 \\
Atlantic & 36 & 1,20 & 54 & 68 & 2,51 & 41 \\
Markies & 20 & 0,80 & 49 & 50 & 2,08 & 38 \\
Mondial & 22 & 0,53 & 57 & 47 & 2,17 & 41 \\
\hline
\end{tabular}

Os acúmulos de B nas plantas inteiras, foram ajustados a modelos sigmóides de regressão (Figura 20F). Em todas as cultivares os acúmulos de B foram lentos e semelhantes até aos 34 DAP, coincidindo com o período de menor acúmulo de MS. Nesse período a cultivar Atlantic absorveu em torno de 33\% do total de B acumulado, proporção maior que a observada nas demais cultivares (Tabela 27). No início da fase de enchimento dos tubérculos (42 a 62 DAP) as cultivares Ágata, Markies, Mondial e Asterix absorveram entre 
$46 \%$ e $51 \%$ do total de $\mathrm{B}$ extraído, proporções essas maiores que àquelas observadas em Atlantic no mesmo período (Tabela 27).

Observa-se que com exceção da cultivar Mondial que absorveu aproximadamente $24 \%$ do total de B extraído, na fase final de enchimento de tubérculos, nas demais cultivares a maior parte do B foi absorvido no início do ciclo, ou seja, na fase de crescimento vegetativo, tuberização e no início de fase de enchimento de tubérculos (Tabela 27). Esse comportamento se explica pelas maiores taxas diárias de absorção de $B$ nas cultivares Ágata, Asterix, Atlantic e Markies estarem concentradas praticamente todas antes dos 55 DAP (Figura 21B), o que refletiu em crescimento exponencial do acúmulo de B pelas plantas destas cultivares durante esse período (Figura 20F). Além do fato das maiores taxas de absorção terem ocorrido nesse período (Figura 21B), o maior acúmulo de B observado na cultivar Asterix, entre 48 e 55 DAP, também está relacionado com os maiores acúmulos de MS apresentados por essa cultivar (Figura 5F). Contudo, a partir dos 69 DAP, quando já tinham ocorrido as maiores taxas de absorção de B na cultivar Mondial (Figura 21B) e o acúmulo de MS nessa cultivar ainda encontrava-se crescente (Figura 5F), assim, houve o aumento contínuo do acúmulo de B nessa cultivar, a qual passou a ser semelhante ao obtido na cultivar Asterix até o final do ciclo (Figura 20F).

Tabela 27. Percentual de B acumulado pelas plantas em cada fase do desenvolvimento das cultivares de batata (valores obtidos nas equações ajustadas).

\begin{tabular}{lccccc}
\hline \multirow{2}{*}{ Cultivares } & \multicolumn{5}{c}{ Dias após o plantio/Fase da cultura } \\
\cline { 2 - 6 } & $\begin{array}{c}0-34 \\
\text { Crescimento vegetativo }\end{array}$ & $\begin{array}{c}35-41 \\
\text { Tuberização }\end{array}$ & $\begin{array}{c}42-62 \\
\text { Enchimento de tubérculos }\end{array}$ & $\begin{array}{c}91-97 \\
\text { Maturação }\end{array}$ \\
\hline \multirow{2}{*}{ Ágata } & 22 & 21 & 51 & 6 & 0 \\
Asterix & 27 & 23 & 46 & 4 & 0 \\
Atlantic & 33 & 28 & 37 & 2 & 0 \\
Markies & 22 & 28 & 48 & 2 & 0 \\
Mondial & 16 & 11 & 48 & 24 & 1 \\
\hline
\end{tabular}

No final do ciclo, os menores acúmulos de B ocorreram nas cultivares Ágata, Atlantic e Markies, as quais acumularam 52, 50 e $47 \mathrm{~g} \mathrm{ha}^{-1}$, respectivamente, enquanto as cultivares Asterix e Mondial acumularam 68 e $74 \mathrm{~g} \mathrm{ha}^{-1}$ (Figura 20F e Tabela 26). Yorinori (2003) observou na cultivar Atlantic acúmulos totais de B de 107,3 $\mathrm{g} \mathrm{ha}^{-1}$ (safra das águas) e 
$84,3 \mathrm{~g} \mathrm{ha}^{-1}$ (safra das secas) aos 111 e 71 DAP, respectivamente, ou seja, superiores aos observados em todas as cultivares estudadas.

Os valores das taxas diárias de absorção foram crescentes da emergência até entre 38 e 58 DAP, quando ocorreu o período de máxima taxa de absorção de B pelas cultivares (Figura 21B). No entanto, fica claro que as cultivares Ágata e Asterix são mais eficientes em acumular B nos tubérculos em comparação às demais, uma vez que as taxas diárias de acúmulo de $\mathrm{B}$ nos tubérculos dessas cultivares foram superiores àquelas obtidas nas demais (Figura 21 e Tabela 26). Com isso, observa-se que apesar da MS de tubérculos (Figura 5E), da planta inteira (Figura 5F) e do acúmulo de B na planta inteira das cultivares Mondial e Asterix (Figura 20F) terem sido maior que os obtidos em Ágata, o acúmulo de $\mathrm{B}$ nos tubérculos dessa cultivar foi semelhante ao obtido nas cultivares Asterix e Mondial (Figura 20E).

\subsubsection{Cobre}

$\mathrm{O}$ teor de $\mathrm{Cu}$ nos tubérculos-semente apresentou certas variações no decorrer do ciclo, no entanto, nas últimas avaliações os teores foram sempre inferiores aos observados no plantio (Tabela 28). Nas raízes, hastes, folhas e tubérculos, ocorreram bastantes variações no teor de $\mathrm{Cu}$ durante o ciclo, de forma, que não observou-se um padrão de comportamento contínuo. Mesmo havendo variações, constatou-se que na fase final do ciclo os maiores teores ocorrem normalmente primeiro nas folhas, seguido das raízes, tubérculos e hastes.

Nos tubérculos-semente, as quantidades de $\mathrm{Cu}$ reduziram de forma contínua durante o desenvolvimento da cultura em todas as cultivares estudadas (Figura 22A). No momento do plantio as maiores quantidades de $\mathrm{Cu}$ foram observadas nos tubérculossemente da cultivar Asterix, porém, aos 20 DAP apenas as cultivares Markies e Ágata tiveram quantidades de $\mathrm{Cu}$ superiores àquelas observadas na cultivar Mondial. A partir dos 27 DAP todas as cultivares apresentaram quantidades semelhantes de $\mathrm{Cu}$ nos tubérculos-semente. 
Tabela 28. Teor de $\mathrm{Cu}$ em cada parte das plantas de cultivares de batata durante o ciclo da cultura.

\begin{tabular}{|c|c|c|c|c|c|c|c|c|c|c|c|c|c|}
\hline \multirow{2}{*}{ Cultivares } & \multicolumn{13}{|c|}{ Dias após o plantio } \\
\hline & 0 & 20 & 27 & 34 & 41 & 48 & 55 & 62 & 69 & 76 & 83 & 90 & 97 \\
\hline & \multicolumn{13}{|c|}{$\begin{array}{l}\mathrm{mg} \mathrm{kg}^{-1} \\
\text { Tubérculos-semente }\end{array}$} \\
\hline Ágata & 14 & 21 & 21 & 25 & 23 & 33 & 10 & 8 & - & - & - & - & - \\
\hline Asterix & 24 & 12 & 16 & 31 & 14 & 19 & 10 & 10 & - & - & - & - & - \\
\hline Atlantic & 16 & 17 & 12 & 31 & 12 & 35 & 11 & 7 & - & - & - & - & - \\
\hline Markies & 22 & 21 & 17 & 30 & 13 & 22 & 5 & 5 & - & - & - & - & - \\
\hline \multirow[t]{2}{*}{ Mondial } & 22 & 11 & 17 & 19 & 13 & 28 & 6 & 5 & - & - & - & - & - \\
\hline & \multicolumn{13}{|c|}{ Raízes } \\
\hline Ágata & - & 11 & 23 & 16 & 17 & 12 & 12 & 12 & 11 & 16 & 18 & 15 & 16 \\
\hline Asterix & - & 12 & 15 & 16 & 12 & 13 & 15 & 12 & 14 & 18 & 17 & 17 & 22 \\
\hline Atlantic & - & 14 & 18 & 17 & 13 & 14 & 17 & 16 & 15 & 16 & 20 & 23 & 24 \\
\hline Markies & - & 14 & 16 & 20 & 13 & 11 & 15 & 12 & 12 & 13 & 20 & 23 & 23 \\
\hline Mondial & - & 15 & 16 & 14 & 15 & 13 & 16 & 13 & 12 & 15 & 17 & 13 & 17 \\
\hline & \multicolumn{13}{|c|}{ Hastes } \\
\hline Ágata & - & 11 & 8 & 12 & 25 & 6 & 13 & 10 & 5 & 6 & 12 & 11 & 9 \\
\hline Asterix & - & 12 & 7 & 11 & 18 & 7 & 9 & 7 & 6 & 7 & 7 & 6 & 8 \\
\hline Atlantic & - & 15 & 5 & 23 & 20 & 13 & 14 & 8 & 7 & 10 & 8 & 10 & 11 \\
\hline Markies & - & 11 & 8 & 20 & 8 & 8 & 10 & 7 & 8 & 13 & 12 & 9 & 13 \\
\hline Mondial & - & 13 & 20 & 19 & 7 & 8 & 13 & 11 & 8 & 11 & 9 & 10 & 10 \\
\hline & \multicolumn{13}{|c|}{ Folhas } \\
\hline Ágata & - & 23 & 17 & 19 & 22 & 14 & 14 & 15 & 25 & 24 & 22 & 34 & 17 \\
\hline Asterix & - & 21 & 27 & 14 & 17 & 10 & 17 & 11 & 19 & 12 & 15 & 18 & 17 \\
\hline Atlantic & - & 37 & 36 & 15 & 21 & 10 & 12 & 10 & 17 & 15 & 23 & 22 & 24 \\
\hline Markies & - & 37 & 32 & 12 & 32 & 10 & 13 & 17 & 21 & 14 & 22 & 15 & 19 \\
\hline Mondial & - & 40 & 24 & 13 & 28 & 14 & 20 & 15 & 21 & 26 & 22 & 18 & 22 \\
\hline & \multicolumn{13}{|c|}{ Tubérculos } \\
\hline Ágata & - & - & - & 14 & 21 & 7 & 12 & 6 & 12 & 8 & 13 & 19 & 14 \\
\hline Asterix & - & - & - & 21 & 36 & 6 & 17 & 5 & 12 & 17 & 15 & 18 & 25 \\
\hline Atlantic & - & - & - & 42 & 39 & 6 & 27 & 10 & 21 & 14 & 20 & 17 & 11 \\
\hline Markies & - & - & - & 31 & 34 & 8 & 10 & 5 & 12 & 15 & 12 & 15 & 18 \\
\hline Mondial & - & - & - & 36 & 21 & 8 & 13 & 14 & 26 & 13 & 14 & 10 & 14 \\
\hline
\end{tabular}

As quantidades de $\mathrm{Cu}$ acumuladas nas raízes, aumentaram a partir da emergência das plantas, atingindo os acúmulos máximos estimados de 0,19, 0,35, 0,34, 0,26 e 0,23 $\mathrm{g} \mathrm{ha}^{-1}$ aos 45, 52, 61, 97 e 65 DAP para as cultivares Ágata, Asterix, Atlantic, Markies, e Mondial, respectivamente (Figura 22B). Yorinori (2003) observou acúmulo máximo de $\mathrm{Cu}$ nas raízes da cultivar Atlantic de 0,46 $\mathrm{g} \mathrm{ha}^{-1}$ na safra das águas (111 DAP) e 0,32 $\mathrm{g} \mathrm{ha}^{-1}$ na safra das secas (56 DAP), ou seja, apenas as cultivares Asterix e Atlantic apresentaram acúmulo de $\mathrm{Cu}$ nas raízes maiores que aos obtidos por esse autor na safra das secas. De 
maneira geral, o acúmulo de $\mathrm{Cu}$ nas raízes da cultivar Asterix foi maior que o da cultivar Ágata até aos 48 DAP, porém, dos 55 DAP até o final do ciclo as cultivares Asterix e Atlantic apresentaram acúmulo semelhante de $\mathrm{Cu}$ em suas raízes e superior aos encontrados na cultivar Ágata.

Os acúmulos de $\mathrm{Cu}$ nas raízes da cultivar Mondial nas últimas avaliações também foram inferiores àqueles obtidos nas cultivares Asterix e Atlantic (Figura 22B). Embora as curvas que descrevam a acumulação de MS nas raízes da cultivar Atlantic tenham apresentado valores inferiores aos observados na cultivar Asterix (Figura 5B), o acúmulo de $\mathrm{Cu}$ nas raízes da cultivar Atlantic apresentou valores maiores que os da Asterix a partir dos 62 DAP (Figura 22B), devido aos maiores teores de $\mathrm{Cu}$ nas raízes de Atlantic em comparação à Asterix (Tabela 28). Comportamento semelhante a esse também foi observado entre as cultivares Mondial e Markies, no qual os maiores teores radiculares de $\mathrm{Cu}$ ocorridos na Markies na fase final do ciclo (Tabela 28), proporcionou maiores acúmulos desse elemento em suas raízes, quando comparada à Mondial (Figura 22B).

Os acúmulos de $\mathrm{Cu}$ nas hastes foram semelhantes entre as cultivares da emergência até aos 34 DAP (Figura 22C). Aos 41 DAP as cultivares Asterix e Atlantic apresentaram acúmulos de $\mathrm{Cu}$ nas hastes superiores aos observados nas cultivares Asterix e Mondial. No entanto, a partir dos 48 DAP, as quantidades de $\mathrm{Cu}$ acumuladas nas hastes das cultivares Ágata, Asterix, Atlantic e Markies não diferiram até o final do ciclo. Embora no início do ciclo a cultivar Mondial tenha apresentado pequeno acúmulo de $\mathrm{Cu}$ nas hastes, a quantidade desse elemento acumulada nas hastes dessa cultivar aumentou com o decorrer do ciclo e, tornou-se superior à observada nas demais cultivares a partir dos 62 DAP. Mesmo a cultivar Asterix apresentando maior acúmulo de MS nas hastes (Figura 5C) que Atlantic, Ágata e Markies, o acúmulo de $\mathrm{Cu}$ nas hastes dessas cultivares foi semelhante (Figura 22C), em função dos menores teores de $\mathrm{Cu}$ observados nas hastes da cultivar Asterix (Tabela 28). Os acúmulos máximos de $\mathrm{Cu}$ nas hastes foram de 1,73, 2,39, 2,37, 2,11 e 5,63 $\mathrm{g} \mathrm{ha}^{-1} \mathrm{e}$, ocorreram aos 97, 60, 51, 84 e 83 DAP, nas cultivares Ágata, Asterix, Atlantic, Markies e Mondial, respectivamente. 

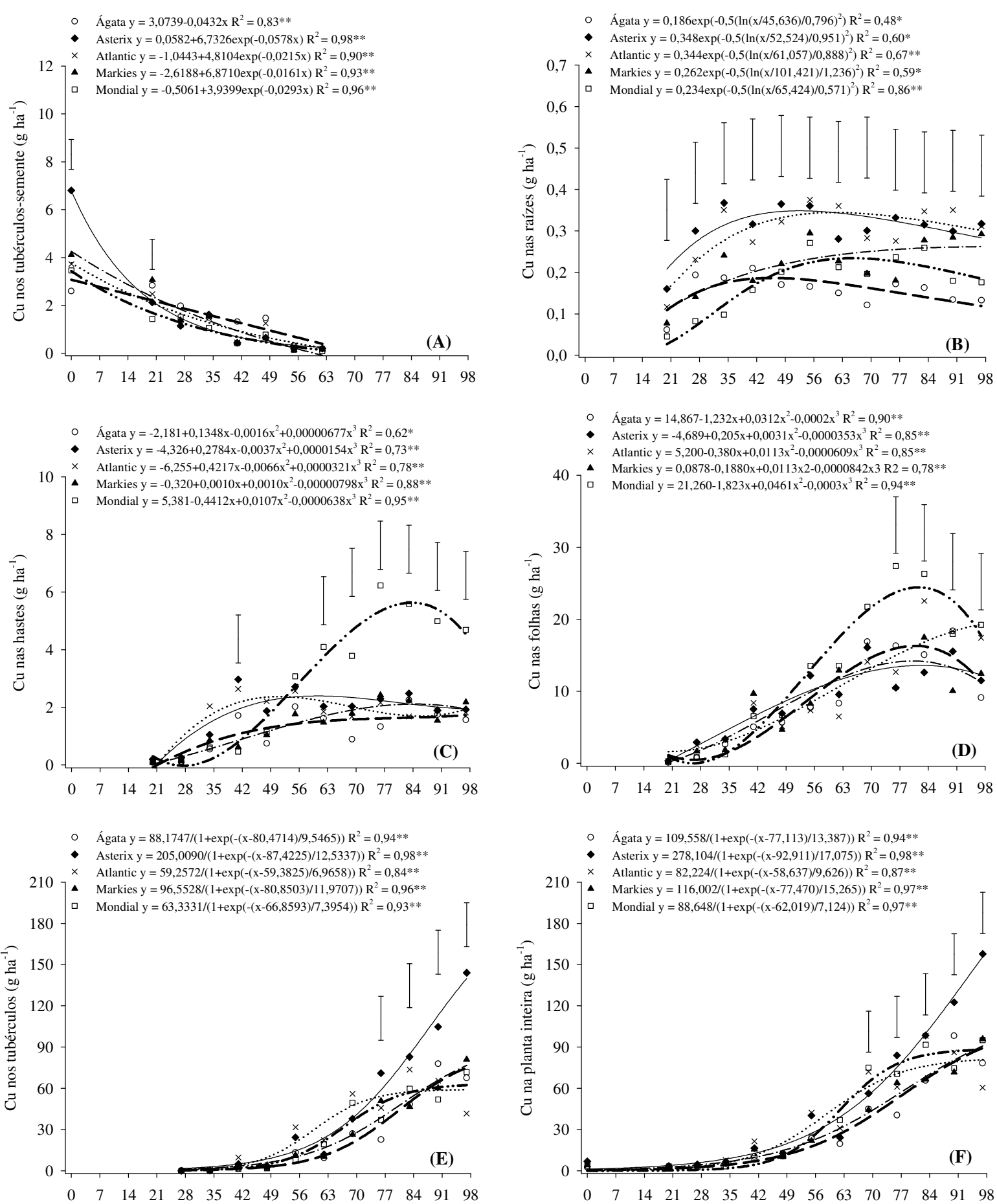

Dias após o plantio

Figura 22. Quantidade de Cu nos tubérculos-semente (A), raízes (B), hastes (C), folhas (D), tubérculos (E) e na planta inteira $(\mathrm{F})$ de cultivares de batata ao longo do ciclo. * e ** significativo a $5 \%$ e $1 \%$ de probabilidade pelo teste F. Barras verticais indicam o valor de DMS pelo teste Tukey a $5 \%$ de probabilidade. 
Nas folhas, as quantidades de $\mathrm{Cu}$ acumuladas foram semelhantes entre as cultivares até aos 69 DAP (Figura 22D). Aos 76 DAP as folhas da cultivar Mondial apresentaram acúmulo de $\mathrm{Cu}$ superior ao obtido nas demais cultivares, enquanto, os menores acúmulos foliares de $\mathrm{Cu}$ foram observados nas cultivares Asterix, Markies e Ágata respectivamente aos 83, 90 e 97 DAP. No final do ciclo apenas a cultivar Mondial apresentou acúmulo de $\mathrm{Cu}$ nas folhas superior ao obtido em Ágata. Os maiores teores de $\mathrm{Cu}$ ocorridos nas folhas da cultivar Atlantic, no final do ciclo (Tabela 28), foram responsáveis pelos valores semelhantes de acúmulo de $\mathrm{Cu}$ nas folhas das cultivares Mondial e Atlantic, uma vez que a MS foliar de Atlantic foi inferior (Figura 5D). Os acúmulos máximos de $\mathrm{Cu}$ nas folhas foram de $16,3,13,6,19,3,14,2$ e 24,4 $\mathrm{g} \mathrm{ha}^{-1}$ e ocorreram aos 80, 82, 97, 80 e 82 DAP, nas cultivares Ágata, Asterix, Atlantic, Markies e Mondial, respectivamente.

Os acúmulos de $\mathrm{Cu}$ nos tubérculos apresentaram ajustes a modelos sigmóides de regressão (Figura 22E). $\mathrm{O}$ acúmulo de $\mathrm{Cu}$ nos tubérculos foi lento e não diferiu entre as cultivares até aos 69 DAP. No final da fase de enchimento de tubérculos, o acúmulo de $\mathrm{Cu}$ nos tubérculos da cultivar Asterix foi superior ao obtido nas cultivares Ágata e Mondial aos 76 DAP e nas cultivares Ágata e Markies aos 83 DAP. No entanto, com o aumento crescente da quantidade de $\mathrm{Cu}$ acumulada nos tubérculos da cultivar Asterix no final do ciclo, esta passou a apresentar quantidade acumulada superior às demais cultivares. Os maiores acúmulos de $\mathrm{Cu}$ nos tubérculos da cultivar Asterix, principalmente no final do ciclo, estão relacionados com os maiores acúmulos de MS (Figura 5E) e com as maiores taxas de acúmulo de $\mathrm{Cu}$ dessa cultivar durante esse período (Figura 23 e Tabela 29). Os acúmulos máximos estimados de $\mathrm{Cu}$ nos tubérculos no final do ciclo foram de 75, 140, 59, 77 e $62 \mathrm{~g}^{-1}$ pelas cultivares Ágata, Asterix, Atlantic, Markies e Mondial, respectivamente (Figura 22E). Nessa época a quantidade de $\mathrm{Cu}$ acumulada nos tubérculos representou em torno de $70 \%$ a $73 \%$ nas cultivares Mondial e Atlantic, aproximadamente $84 \%$ nas cultivares Ágata e Markies e por volta de $90 \%$ na cultivar Asterix (Figura 22E e Tabela 29). Essa maior quantidade de Cu nos tubérculos da cultivar Asterix, também está relacionada com as maiores taxas de acúmulo desse nutriente (Figura 23 e Tabela 29), demonstrando que essa cultivar é mais eficiente que às demais em acumular esse elemento nos tubérculos. 

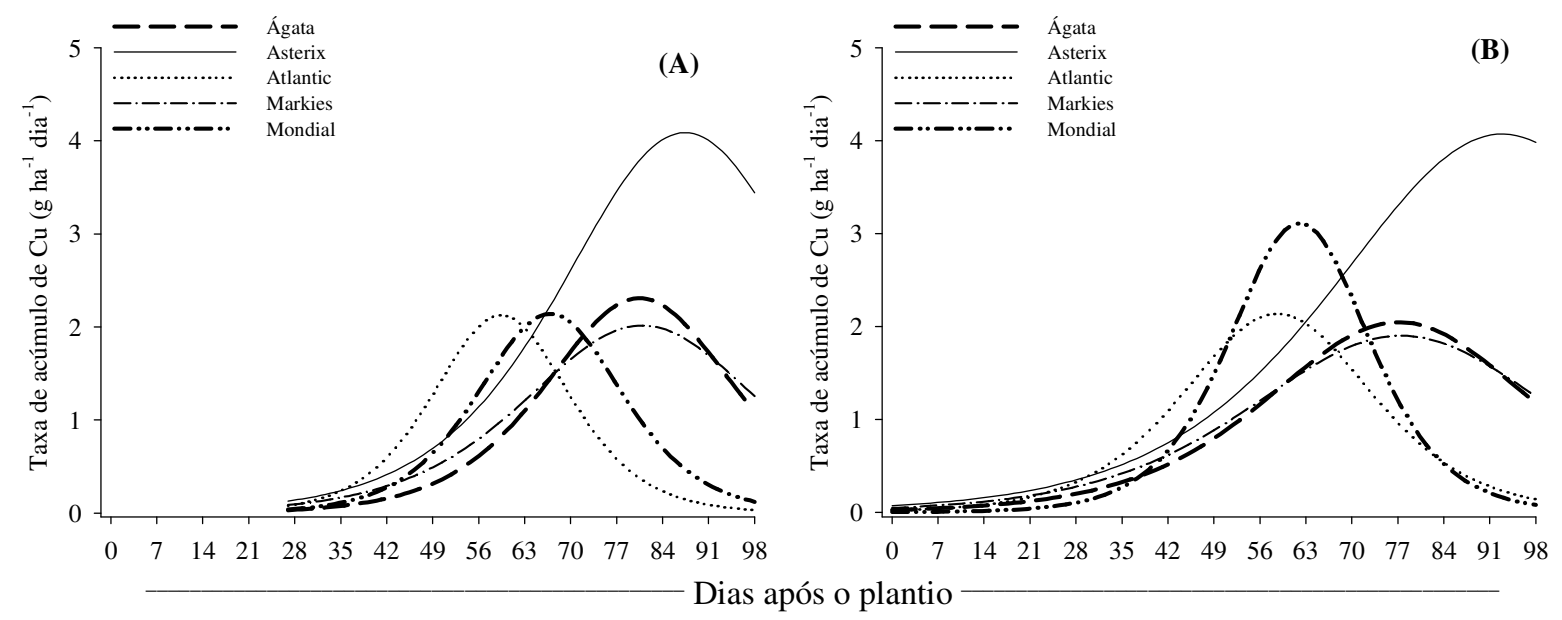

Figura 23. Taxa de acúmulo de $\mathrm{Cu}$ nos tubérculos (A) e nas plantas (B) de cultivares de batata ao longo do ciclo.

Tabela 29. Quantidade máxima de $\mathrm{Cu}$ acumulada, taxa diária máxima de acúmulo e época de maior taxa de acúmulo de $\mathrm{Cu}$ nos tubérculos e nas plantas de cultivares de batata.

\begin{tabular}{lcccccc}
\hline Cultivares & $\begin{array}{c}\text { Acúmulo } \\
\text { máximo no } \\
\text { tubérculo }\end{array}$ & $\begin{array}{c}\text { Taxa } \\
\text { máxima de } \\
\text { acúmulo no } \\
\text { tubérculo }\end{array}$ & $\begin{array}{c}\text { Época de } \\
\text { maior taxa } \\
\text { de acúmulo } \\
\text { no tubérculo }\end{array}$ & $\begin{array}{c}\text { Acúmulo } \\
\text { máximo na } \\
\text { planta }\end{array}$ & $\begin{array}{c}\text { Taxa } \\
\text { máxima de } \\
\text { acúmulo na } \\
\text { planta }\end{array}$ & $\begin{array}{c}\text { Época de } \\
\text { maior taxa de } \\
\text { acúmulo na } \\
\text { planta }\end{array}$ \\
\hline Ágata & $\mathrm{g} \mathrm{ha}^{-1}$ & $\mathrm{~g} \mathrm{ha}^{-1} \mathrm{dia}^{-1}$ & $\begin{array}{c}\mathrm{DAP} \\
\mathrm{g} \mathrm{ha}^{-1}\end{array}$ & $\mathrm{~g} \mathrm{ha}^{-1} \mathrm{dia}^{-1}$ & $\mathrm{DAP}$ \\
Asterix & 75 & 2,30 & 80 & 89 & 2,04 & 77 \\
Atlantic & 140 & 4,08 & 87 & 156 & 4,07 & 93 \\
Markies & 59 & 2,12 & 60 & 81 & 2,13 & 59 \\
Mondial & 77 & 2,01 & 81 & 91 & 1,89 & 77 \\
\hline
\end{tabular}

Com relação as plantas inteiras, as quantidades de $\mathrm{Cu}$ acumuladas apresentaram ajustes a modelos sigmóides de regressão (Figura 22F). As curvas que descrevem a acumulação de $\mathrm{Cu}$ nas plantas de todas as cultivares tiveram crescimento lento e não diferiram entre si até aos 62 DAP, demonstrando que durante as fases iniciais de desenvolvimento todas as cultivares são pouco exigentes em $\mathrm{Cu}$. Esta constatação torna-se mais evidente quando observa-se que durante a fase de crescimento vegetativo e tuberização houve baixa absorção de $\mathrm{Cu}$ em todas as cultivares, (Tabela 30) uma vez que, nesse período as taxas diárias de absorção foram baixas e a cultivar Atlantic, que apresentou as maiores taxas 
diárias de absorção nesse período (Figura 23B) havia absorvido apenas $14 \%$ do total extraído (Figura 23B e Tabela 30).

Tabela 30. Percentual de $\mathrm{Cu}$ acumulado pelas plantas em cada fase do desenvolvimento das cultivares de batata (valores obtidos nas equações ajustadas).

\begin{tabular}{lccccc}
\hline \multirow{2}{*}{ Cultivares } & \multicolumn{5}{c}{ Dias após o plantio/Fase da cultura } \\
\cline { 2 - 6 } & $\begin{array}{c}0-34 \\
\text { Crescimento vegetativo }\end{array}$ & $\begin{array}{c}35-41 \\
\text { Tuberização }\end{array}$ & $\begin{array}{c}42-62 \\
\text { Enchimento de tubérculos }\end{array}$ & $\begin{array}{c}91-97 \\
\text { Maturação }\end{array}$ \\
\cline { 2 - 6 } Agata & 5 & 3 & 22 & 59 & 11 \\
Asterix & 5 & 3 & 17 & 57 & 18 \\
Atlantic & 7 & 7 & 45 & 39 & 2 \\
Markies & 7 & 3 & 22 & 55 & 13 \\
Mondial & 2 & 3 & 46 & 48 & 1 \\
\hline
\end{tabular}

Aos 69 DAP, a cultivar Mondial apresentou acúmulo de $\mathrm{Cu}$ superior ao obtido nas cultivares Markies e Ágata, em parte, devido ao fato das maiores taxas de absorção de $\mathrm{Cu}$ terem antecedido esse período e terem sido superiores ao de todas as cultivares, nessa época (Figuras 22F e 23B). A partir dos 84 DAP, o aumento na quantidade de $\mathrm{Cu}$ acumulada pelas plantas da cultivar Asterix (Figura 22F), coincidiu com a época de maior taxa de absorção desse elemento (Figura 23B e Tabela 29), o que proporcionou, na última avaliação, acúmulo de $\mathrm{Cu}$ nas plantas da cultivar Asterix superior aos obtidos em todas as demais cultivares. As cultivares Ágata e Markies apresentaram comportamento semelhante ao obtido em Asterix, contudo, como as taxas diárias de absorção $\mathrm{Cu}$ nessas cultivares foram inferiores às obtidas em Asterix no mesmo período, o acúmulo também foi menor (Figura 23B e Figura 22F). No final do ciclo, os acúmulos máximos de $\mathrm{Cu}$ foram estimados em 89, 156, 81,91 e $88 \mathrm{~g} \mathrm{ha}^{-1}$ nas cultivares Ágata, Asterix, Atlantic, Markies e Mondial, respectivamente (Figura 22F e Tabela 29).

Verifica-se que a absorção de $\mathrm{Cu}$ em todas as cultivares ocorreu em maiores proporções na época de enchimento de tubérculos, pois, nesse período observou-se os maiores aumentos no acúmulo de $\mathrm{Cu}$ (Figura 22F), as maiores taxas de absorção (Figura 23B) e foi quando ocorreu a maior parte da absorção (Tabela 30). No entanto, a proporção de $\mathrm{Cu}$ absorvida pelas cultivares Ágata, Asterix e Markies durante a fase de maturação foi maior que a ocorrida desde a emergência até aos 41 DAP (Tabela 30), demonstrando que a maior parte 
da absorção desse elemento ocorre durante o enchimento de tubérculos, porém, estende-se até o final do ciclo.

\subsubsection{Ferro}

De maneira geral, os teores de Fe nos tubérculos-semente, raízes, hastes e folhas aumentaram com o decorrer do ciclo (Tabela 31). No entanto, comportamento contrário foi observado nos tubérculos em que os teores de Fe foram decrescentes desde o início da tuberização até o final do ciclo. Entre os órgãos das plantas os maiores teores ocorreram nas raízes, seguidas das folhas, hastes, tubérculos-semente e tubérculos. Dechen e Nachtigall (2006) relataram que o Fe é considerado de baixa mobilidade nos tecidos vegetais, e, que devido a baixa taxa de translocação, pode ocorrer acumulação de $\mathrm{Fe}$ nas raízes, enquanto, ao mesmo tempo folhas jovens apresentem sintomas de deficiência desse elemento. Dessa forma fica evidente, que os maiores teores radiculares é resultado do comportamento comum desse elemento em acumular-se nas raízes.

As quantidades de $\mathrm{Fe}$ nos tubérculos-semente diminuíram desde o plantio até a última avaliação, em todas as cultivares (Figura 24A). No plantio os tubérculossemente com maiores quantidades de Fe foram os da cultivar Atlantic, enquanto os da cultivar Asterix, tiveram quantidades de Fe superiores apenas àquelas observadas na cultivar Mondial. Aos 20 DAP, a quantidade de Fe nos tubérculos-semente da cultivar Asterix foi superior à encontrada na cultivar Ágata, a qual, juntamente com Mondial, apresentou conteúdos de Fe inferiores aos obtidos em Atlantic aos 34 DAP. Nota-se que mesmo a cultivar Asterix tendo apresentado maior MS de tubérculos-semente no momento do plantio (Figura 5A), a maior quantidade de Fe foi encontrada nos tubérculos-semente da cultivar Atlantic, o que está relacionado com os maiores teores desse elemento observados nos tubérculos-semente da cultivar Atlantic em relação à Asterix (Tabela 31). 
Tabela 31. Teor de Fe em cada parte das plantas de cultivares de batata durante o ciclo da cultura.

\begin{tabular}{|c|c|c|c|c|c|c|c|c|c|c|c|c|c|}
\hline \multirow{2}{*}{ Cultivares } & \multicolumn{13}{|c|}{ Dias após o plantio } \\
\hline & 0 & 20 & 27 & 34 & 41 & 48 & 55 & 62 & 69 & 76 & 83 & 90 & 97 \\
\hline \multirow{7}{*}{$\begin{array}{l}\text { Ágata } \\
\text { Asterix } \\
\text { Atlantic } \\
\text { Markies } \\
\text { Mondial }\end{array}$} & \multicolumn{13}{|c|}{ Tubérculos-semente } \\
\hline & 432 & 340 & 290 & 647 & 813 & 886 & 861 & 1.830 & - & - & - & - & - \\
\hline & 312 & 477 & 569 & 1.123 & 1.472 & 1.604 & 916 & 2.167 & - & - & - & - & - \\
\hline & 592 & 432 & 576 & 1.580 & 1.333 & 1.608 & 964 & 1.906 & - & - & - & - & - \\
\hline & 441 & 461 & 397 & 1.157 & 819 & 1.259 & 940 & 1.575 & - & - & - & - & - \\
\hline & 307 & 387 & 275 & 883 & 956 & 1.253 & 592 & 1.440 & - & $\begin{array}{c}- \\
-\end{array}$ & - & - & - \\
\hline & \multicolumn{13}{|c|}{ Raízes } \\
\hline \multirow{6}{*}{$\begin{array}{l}\text { Ágata } \\
\text { Asterix } \\
\text { Atlantic } \\
\text { Markies } \\
\text { Mondial }\end{array}$} & - & 2.509 & 4.533 & 3.823 & 6.130 & 6.030 & 2.960 & 4.941 & 6.031 & 6.610 & 6.415 & 6.125 & 6.305 \\
\hline & - & 2.964 & 3.024 & 4.483 & 4.639 & 5.757 & 4.687 & 4.962 & 6.906 & 7.780 & 6.229 & 7.402 & 4.932 \\
\hline & - & 2.811 & 3.259 & 4.053 & 6.558 & 6.293 & 4.629 & 5.661 & 7.045 & 6.867 & 6.931 & 6.649 & 4.830 \\
\hline & - & 2.870 & 3.309 & 2.817 & 4.753 & 6.161 & 3.873 & 5.404 & 6.211 & 6.468 & 6.573 & 5.849 & 4.314 \\
\hline & - & 2.202 & 2.901 & 4.723 & 6.598 & 5.950 & 4.271 & 6.341 & 6.693 & 7.041 & 5.909 & 4.772 & 3.848 \\
\hline & \multicolumn{13}{|c|}{ Hastes } \\
\hline Ágata & - & 528 & 238 & 601 & 464 & 551 & 493 & 599 & 582 & 630 & 681 & 795 & 676 \\
\hline Asterix & - & 527 & 226 & 493 & 425 & 531 & 331 & 416 & 528 & 424 & 572 & 670 & 617 \\
\hline Atlantic & - & 346 & 238 & 526 & 360 & 506 & 317 & 465 & 397 & 508 & 550 & 825 & 575 \\
\hline Markies & - & 576 & 190 & 533 & 422 & 651 & 423 & 507 & 592 & 778 & 688 & 775 & 706 \\
\hline Mondial & - & 446 & 204 & 347 & 558 & 408 & 380 & 470 & 369 & 405 & 334 & 529 & 428 \\
\hline \multicolumn{14}{|c|}{ Folhas } \\
\hline Ágata & - & 815 & 836 & 791 & 666 & 893 & 1.610 & 963 & 1.119 & 2.077 & 1.647 & 1.951 & 2.184 \\
\hline Asterix & - & 1.118 & 690 & 1.091 & 530 & 852 & 1.007 & 894 & 1.453 & 2.038 & 1.401 & 2.031 & 1.370 \\
\hline Atlantic & - & 962 & 643 & 950 & 633 & 801 & 888 & 699 & 1.736 & 1.858 & 1.601 & 2.203 & 1.504 \\
\hline Markies & - & 933 & 556 & 1.179 & 696 & 944 & 1.606 & 695 & 1.177 & 1.299 & 1.365 & 2.249 & 1.368 \\
\hline Mondial & - & 596 & 409 & 1.273 & 733 & 651 & 1.751 & 964 & 1.640 & 1.640 & 2.129 & 2.352 & 1.804 \\
\hline & \multicolumn{13}{|c|}{ Tubérculos } \\
\hline Ágata & - & - & - & 251 & 184 & 192 & 42 & 57 & 23 & 26 & 44 & 35 & 40 \\
\hline Asterix & - & - & - & 234 & 227 & 211 & 35 & 55 & 24 & 35 & 36 & 25 & 39 \\
\hline Atlantic & - & - & - & 208 & 239 & 167 & 47 & 57 & 29 & 49 & 33 & 31 & 48 \\
\hline Markies & - & - & - & 166 & 191 & 192 & 62 & 68 & 43 & 44 & 39 & 36 & 37 \\
\hline Mondial & - & - & - & 255 & 170 & 164 & 54 & 66 & 31 & 50 & 41 & 32 & 41 \\
\hline
\end{tabular}



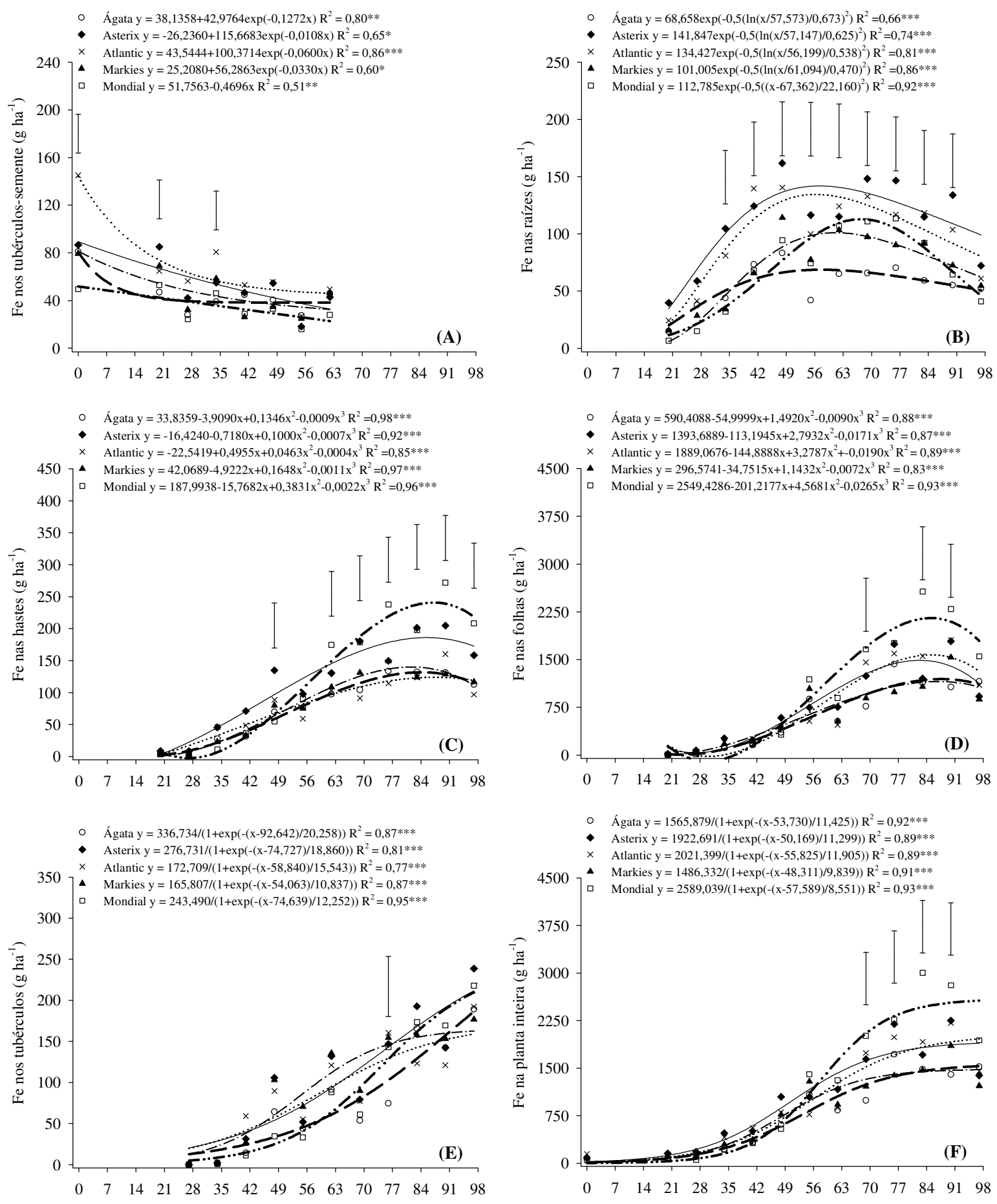

Dias após o plantio

Figura 24. Quantidade de Fe nos tubérculos-semente (A), raízes (B), hastes (C), folhas (D), tubérculos (E) e na planta inteira $(\mathrm{F})$ de cultivares de batata ao longo do ciclo. * significativo a $10 \% * *$ significativo a $5 \%$ e $* * *$ significativo $1 \%$ de probabilidade pelo teste $\mathrm{F}$. Barras verticais indicam o valor de DMS pelo teste Tukey a $5 \%$ de probabilidade. 
Nas raízes, as quantidades acumuladas de $\mathrm{Fe}$ foram semelhantes em todas as cultivares, da emergência até aos 27 DAP e, a partir dos 34 DAP os acúmulos de Fe nas raízes intensificaram-se atingindo os valores máximos estimados de 68,7, 141,9, 134,4, 101,0 e 112,8 $\mathrm{g} \mathrm{ha}^{-1}$ aos 57, 57, 56, 61 e 67 DAP para as cultivares Ágata, Asterix, Atlantic, Markies e Mondial, respectivamente (Figura 24B). Dos 34 DAP aos 48, a cultivar Asterix apresentou acúmulo de $\mathrm{Fe}$ nas raízes semelhante àqueles obtidos em Atlantic, porém, superiores aos observados em todas as outras cultivares. Apesar de aos 62 DAP a cultivar Asterix ter apresentado acúmulo de Fe nas raízes semelhante ao obtido em Ágata, no geral, entre 55 e 90 DAP o acúmulo de Fe nas raízes da cultivar Asterix foi superior ao observado em Ágata. A cultivar Atlantic teve acúmulo de Fe nas raízes semelhante aos encontrados na Asterix, no entanto, superiores aos obtidos na Ágata aos 62, 70, 83 e 90 DAP. Yorinori (2003) observou acúmulo máximo de Fe nas raízes da cultivar Atlantic de 54,2 $\mathrm{g} \mathrm{ha}^{-1}$ na safra das águas (65 DAP) e 41,8 $\mathrm{g} \mathrm{ha}^{-1}$ na safra das secas (44 DAP), os quais foram inferiores aos observados no presente experimento para todas as cultivares.

Os acúmulos de Fe nas hastes apresentaram ajustes a modelos cúbicos de regressão, sendo semelhantes entre as cultivares da emergência até aos 41 DAP (Figura 24C). As quantidades máximas estimadas de Fe acumuladas nas hastes foram de 131,7, 186,0, $123,9,140,0$ e 240,7 $\mathrm{g} \mathrm{ha}^{-1}$ e, ocorreram aos 84, 85, 87, 81 e 87 DAP, respectivamente, para as cultivares Ágata, Asterix, Atlantic, Markies e Mondial. Aos 48 DAP o acúmulo de Fe nas hastes da cultivar Asterix foi maior que o observado na cultivar Mondial, porém, com o aumento intenso do acúmulo de Fe nas hastes da cultivar Mondial, após esse período a mesma passou a apresentar acúmulo de Fe semelhante ao obtido em Asterix até o final do ciclo, exceto aos 76 DAP em que todas as cultivares apresentaram acúmulos menores que a Mondial. Verifica-se que embora a cultivar Mondial tenha apresentado MS de hastes significativamente maior que a observada em Asterix no final do ciclo (Figura 5C), ambas as cultivares tiveram acúmulo semelhante de Fe em suas hastes durante esse período (Figura 24C), o que é reflexo dos menores teores de Fe observados nas hastes da cultivar Mondial nas últimas avaliações (Tabela 31).

As quantidades de Fe acumuladas nas folhas, aumentaram sem diferir entre as cultivares até aos 63 DAP e, permaneceu aumentando até atingir os acúmulos máximos estimados de 1.193, 1.488, 1.574, 1.155 e $2.152 \mathrm{~g} \mathrm{ha}^{-1}$, aos 87, 82, 85, 86 e 85 DAP, 
respectivamente, nas cultivares Ágata, Asterix, Atlantic, Markies e Mondial (Figura 24D). Aos 69 e 90 DAP o acúmulo de Fe nas folhas da cultivar Mondial foi superior ao obtido na cultivar Ágata, no entanto, aos 83 DAP quando a cultivar Mondial atingiu os maiores acúmulos de Fe nas folhas, a quantidade de Fe acumulada nas folhas dessa cultivar foi maior que a observada em todas as demais cultivares.

Os tubérculos acumularam $\mathrm{Fe}$ continuamente desde o início da tuberização até o final do ciclo, atingindo acúmulos máximos estimados de 186, 212, 159, 163 e $209 \mathrm{~g} \mathrm{ha}^{-1}$ pelas cultivares Ágata, Asterix, Atlantic, Markies e Mondial, respectivamente (Figura 24E e Tabela 32). Durante todo o ciclo, os acúmulos de Fe nos tubérculos de todas as cultivares foram semelhantes. No entanto, aos 76 DAP, as quantidades de Fe acumuladas nos tubérculos das cultivares Markies e Atlantic foram maiores que as observadas na cultivar Ágata. (Figura 24E). No final do ciclo, todas as cultivares apresentaram menos de 12,5\% de todo o Fe absorvido acumulado nos tubérculos (Figura 24E e Tabela 32), fato esse que está relacionado com as baixas taxas de acumulação de Fe nos tubérculos (Figura 25A e Tabela 32), o que é resultado da baixa redistribuição desse elemento na planta (MALAVOLTA, 2006), pois, após absorvido o transporte a longa distância é feito principalmente via xilema e sua mobilização para dentro do floema é diminuída principalmente pela formação de compostos insolúveis nas folhas (DECHEN; NACHTIGALL, 2006; TAIZ; ZEIGER, 2004). Este comportamento do Fe na planta, torna-se ainda mais evidente quando observa-se que entre os órgãos das plantas o maior acúmulo de Fe ocorreu nas folhas (Figura 24). 

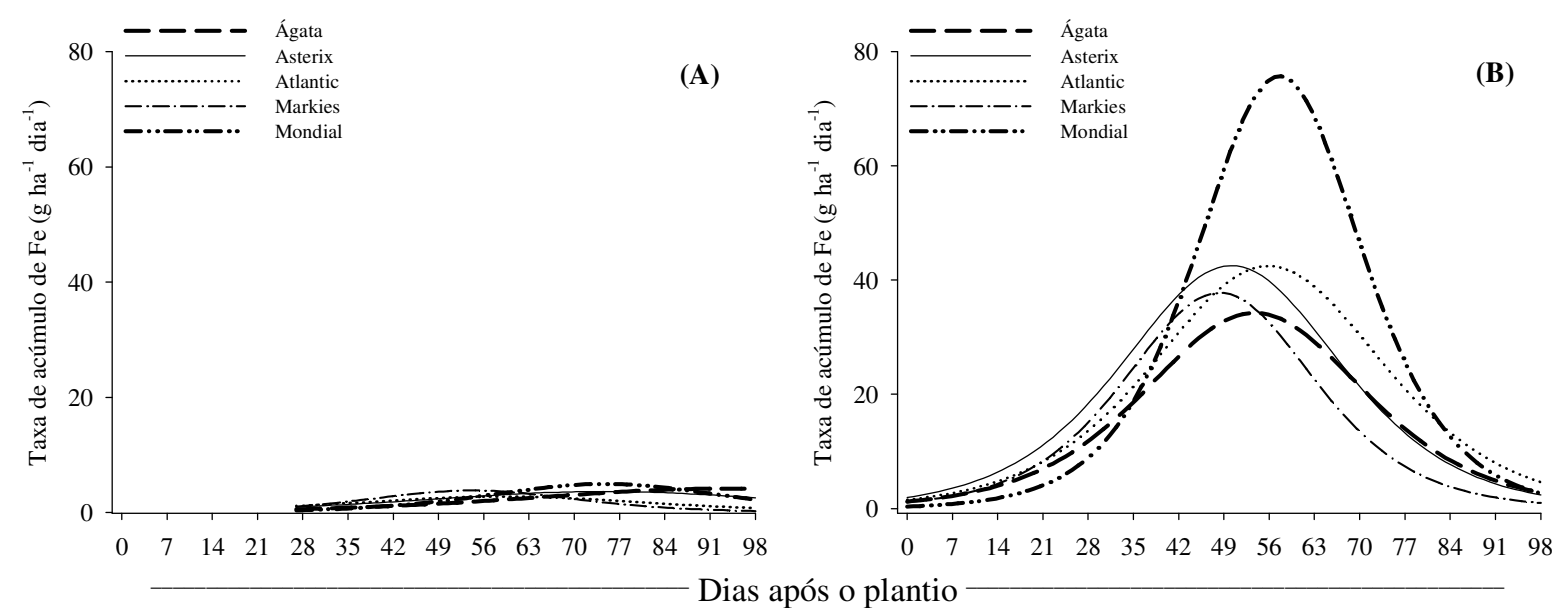

Figura 25. Taxa de acúmulo de Fe nos tubérculos (A) e nas plantas (B) de cultivares de batata ao longo do ciclo.

Tabela 32. Quantidade máxima de Fe acumulada, taxa diária máxima de acúmulo e época de maior taxa de acúmulo de Fe nos tubérculos e nas plantas de cultivares de batata.

\begin{tabular}{|c|c|c|c|c|c|c|}
\hline Cultivares & $\begin{array}{l}\text { Acúmulo } \\
\text { máximo no } \\
\text { tubérculo }\end{array}$ & $\begin{array}{c}\text { Taxa } \\
\text { máxima de } \\
\text { acúmulo no } \\
\text { tubérculo }\end{array}$ & $\begin{array}{c}\text { Época de } \\
\text { maior taxa } \\
\text { de acúmulo } \\
\text { no tubérculo }\end{array}$ & $\begin{array}{l}\text { Acúmulo } \\
\text { máximo na } \\
\text { planta }\end{array}$ & $\begin{array}{c}\text { Taxa } \\
\text { máxima de } \\
\text { absorção da } \\
\text { planta }\end{array}$ & $\begin{array}{l}\text { Época de } \\
\text { máxima } \\
\text { absorção da } \\
\text { planta }\end{array}$ \\
\hline & $\mathrm{g} \mathrm{ha}^{-1}$ & $\mathrm{~g} \mathrm{ha}^{-1} \mathrm{dia}^{-1}$ & DAP & $\mathrm{g} \mathrm{ha}^{-1}$ & $\mathrm{~g} \mathrm{ha}^{-1} \mathrm{dia}^{-1}$ & DAP \\
\hline Ágata & 186 & 4,15 & 92 & 1.531 & 34,26 & 54 \\
\hline Asterix & 212 & 3,66 & 75 & 1.893 & 42,53 & 50 \\
\hline Atlantic & 159 & 2,78 & 59 & 1.960 & 42,45 & 56 \\
\hline Markies & 163 & 3,82 & 54 & 1.476 & 37,75 & 48 \\
\hline Mondial & 209 & 4,96 & 74 & 2.563 & 75,67 & 58 \\
\hline
\end{tabular}

Os dados referentes aos acúmulos de Fe nas plantas inteiras, foram ajustados a modelos sigmóides de regressão (Figura 24F). Embora do plantio até 62 DAP o acúmulo de Fe tenha sido semelhante entre as cultivares, da emergência até o final da tuberização as cultivares Asterix e Markies já tinham absorvido mais de $31 \%$ da quantidade total, o que ocorreu devido as taxas diárias de absorção de Fe nessas cultivares terem sido superiores àquelas apresentadas pelas demais, durante esse mesmo período (Tabela 33 e Figura 25B). De maneira geral, durante o início da fase de enchimento de tubérculos (42 a 62 DAP), ocorreu a maior parte da absorção de Fe em todas as cultivares, uma vez que nessa época obteve-se as maiores taxas diárias de absorção e as cultivares absorveram entre $42 \%$ e $51 \%$ da quantidade total (Figura 25B e Tabela 33). 
Tabela 33. Percentual de Fe acumulado pelas plantas em cada fase do desenvolvimento das cultivares de batata (valores obtidos nas equações ajustadas).

\begin{tabular}{|c|c|c|c|c|c|}
\hline \multirow{3}{*}{ Cultivares } & \multicolumn{5}{|c|}{ Dias após o plantio/Fase da cultura } \\
\hline & $0-34$ & $35-41$ & $42-6$ & $63-90$ & $91-97$ \\
\hline & Crescimento vegetativo & Tuberização & Enchir & gérculos & Maturação \\
\hline Ágata & 16 & 9 & 44 & 29 & 2 \\
\hline Asterix & 20 & 12 & 44 & 23 & 1 \\
\hline Atlantic & 14 & 9 & 42 & 33 & 2 \\
\hline Markies & 19 & 13 & 49 & 18 & 1 \\
\hline Mondial & 6 & 7 & 51 & 35 & 1 \\
\hline
\end{tabular}

Após 62 DAP as taxas diárias de absorção de Fe apresentadas pela cultivar Mondial ainda permaneceram superiores àquelas observadas nas demais cultivares até aos 83 DAP, o que refletiu em maiores quantidades acumuladas de Fe que as obtidas nas cultivares Ágata (69 DAP) e Markies (76 DAP) e em ambas (90 DAP) (Figuras 25B e 24F). Aos 83 DAP, o acúmulo de Fe apresentado pela cultivar Mondial foi maior que o obtido em todas as cultivares (Figura 24F).

No final do ciclo, os acúmulos máximos estimados de Fe apresentados pelas plantas foram de 1.531, 1.893, 1.960, 1.476 e $2.563 \mathrm{~g} \mathrm{ha}^{-1}$ nas cultivares Ágata, Asterix, Atlantic, Markies e Mondial, respectivamente (Figura 24F e Tabela 32). Yorinori (2003) em estudo sobre o crescimento e o acúmulo de nutrientes pela batateira, cultivar Atlantic, obteve acúmulos totais de Fe de $1.229 \mathrm{~g} \mathrm{ha}^{-1}$ (safra das águas) e $790 \mathrm{~g} \mathrm{ha}^{-1}$ (safra das secas) aos $111 \mathrm{e}$ 92 DAP, respectivamente, os quais foram inferiores aos observados no presente experimento, provavelmente, em parte devido aos altos teores de Fe presentes no solo onde conduziu-se este ensaio (Tabela 1).

Observando a Figura 25 e a Tabela 32, verifica-se que a época de maior taxa de absorção de Fe pelas cultivares de batata concentrou-se entre 48 e 58 DAP, porém, nota-se que a taxa máxima com que as plantas acumularam Fe nos tubérculos chegou a ser em média 12 vezes menor que a máxima taxa de absorção, demonstrando que embora tenha ocorrido um período de maior absorção de Fe pelas plantas, esse elemento não foi translocado em grandes quantidades para os tubérculos, uma vez que as taxas máximas de acúmulo de $\mathrm{Fe}$ nos tubérculos ocorridas entre 54 e 92 DAP foram baixas e a maior parte do $\mathrm{Fe}$ absorvido ficou alocado nas folhas (Figura 24). 


\subsubsection{Manganês}

Nos tubérculos-semente, hastes e folhas o teor de Mn aumentou gradativamente do início ao final do ciclo, porém, nas raízes, embora o comportamento tenha sido o mesmo, nas últimas duas avaliações ocorreram certa diminuição (Tabela 34). Nos tubérculos verificaram-se reduções no teor de Mn desde a fase de tuberização e início de enchimento de tubérculos até o final do ciclo. De maneira geral, observou-se que no início do ciclo, os maiores teores de Mn ocorreram nas raízes, mas no final os maiores teores obedeceram a seguinte ordem: folhas, hastes, raízes e tubérculos.

Os conteúdos de $\mathrm{Mn}$ nos tubérculos-semente permaneceram relativamente constantes em todas as cultivares (Figura 26A). Apesar das reduções na MS dos tubérculos-semente (Figura 5A) durante o desenvolvimento da cultura, as quantidades de Mn praticamente não sofreu alterações, o que é resultado dos aumentos nos teores de Mn dos tubérculos-semente (Tabela 34). Observa-se que os tubérculos-semente, das cultivares Asterix e Atlantic apresentaram na maioria das avaliações quantidades de Mn superiores à cultivar Mondial, fato esse que está relacionado com as maiores quantidades de MS presente nos tubérculos-semente das cultivares Asterix e Atlantic (Figura 5A), bem como devido a variações no teor desse elemento no referido órgão (Tabela 34). O fato das quantidades de Mn ter permanecido relativamente constantes está relacionado à sua baixa mobilidade no floema, sendo considerado imóvel na planta (MALAVOLTA, 2006).

As quantidades de $\mathrm{Mn}$ acumuladas nas raízes aumentaram e foram semelhantes entre as cultivares da emergência até aos 27 DAP (Figura 26B). Os acúmulos de Mn nas raízes atingiram os valores máximos estimados de 3,3, 6,2, 7,0, 6,4 e 5,7 $\mathrm{g} \mathrm{ha}^{-1}$ aos 64, 64, 63, 65 e 69 DAP para as cultivares Ágata, Asterix, Atlantic, Markies, e Mondial, respectivamente (Figura 26B). Aos 34 e 41 DAP as cultivares Mondial, Markies e Ágata apresentaram acúmulos de $\mathrm{Mn}$ nas raízes inferiores aos obtidos nas cultivares Asterix e Atlantic, porém, a partir dos 48 DAP o rápido aumento na quantidade de Mn acumulada nas raízes das cultivares Mondial e Markies, proporcionou acúmulo de Mn nas raízes dessas cultivares semelhantes àqueles encontrados nas raízes de Asterix e Atlantic até o final do ciclo. Na cultivar Ágata o aumento na quantidade acumulada de Mn nas raízes foi menor, o que refletiu em acúmulos inferiores aos obtidos nas cultivares Asterix e Atlantic desde a fase 
de tuberização até aos 83 DAP. Embora a cultivar Asterix tenha apresentado maiores acúmulos de MS nas raízes (Figura 5B), a curva que descreve a acumulação de Mn nas raízes dessa cultivar ficou abaixo da curva obtida em Atlantic (Figura 26B), provavelmente, devido aos maiores teores de Mn observados nas raízes da cultivar Atlantic (Tabela 34). As reduções nas quantidades de $\mathrm{Mn}$ acumuladas nas raízes de todas as cultivares, no final do ciclo, estão relacionadas com a morte e diminuição da MS do sistema radicular (Figura 5B), pois, o teor de Mn neste órgão não sofreu grandes alterações (Tabela 34).

Tabela 34. Teor de Mn em cada parte das plantas de cultivares de batata durante o ciclo da cultura.

\begin{tabular}{|c|c|c|c|c|c|c|c|c|c|c|c|c|c|}
\hline \multirow{2}{*}{ Cultivares } & \multicolumn{13}{|c|}{ Dias após o plantio } \\
\hline & 0 & 20 & 27 & 34 & 41 & 48 & 55 & 62 & 69 & 76 & 83 & 90 & 97 \\
\hline & \multicolumn{13}{|c|}{$\begin{array}{l}\mathrm{mg} \mathrm{kg}^{-1} \\
\text { Tubérculos-semente }\end{array}$} \\
\hline Ágata & 23 & 24 & 35 & 53 & 67 & 85 & 113 & 94 & - & - & - & - & - \\
\hline Asterix & 16 & 30 & 65 & 87 & 134 & 144 & 132 & 108 & - & - & - & - & - \\
\hline Atlantic & 23 & 26 & 49 & 72 & 116 & 135 & 150 & 151 & - & - & - & - & - \\
\hline Markies & 14 & 24 & 39 & 55 & 99 & 124 & 148 & 128 & - & - & - & - & - \\
\hline \multirow[t]{2}{*}{ Mondial } & 15 & 21 & 28 & 43 & 86 & 94 & 133 & 109 & - & - & - & - & - \\
\hline & \multicolumn{13}{|c|}{ Raízes } \\
\hline Ágata & - & 113 & 136 & 158 & 177 & 195 & 236 & 244 & 271 & 284 & 282 & 185 & 229 \\
\hline Asterix & - & 139 & 149 & 172 & 206 & 172 & 256 & 261 & 282 & 288 & 314 & 192 & 313 \\
\hline Atlantic & - & 182 & 158 & 199 & 260 & 225 & 345 & 291 & 385 & 341 & 328 & 227 & 255 \\
\hline Markies & - & 133 & 131 & 145 & 214 & 289 & 378 & 289 & 418 & 300 & 398 & 216 & 302 \\
\hline Mondial & - & 131 & 158 & 201 & 266 & 234 & 345 & 288 & 304 & 330 & 359 & 213 & 297 \\
\hline \multicolumn{14}{|c|}{ Hastes } \\
\hline Ágata & - & 58 & 59 & 81 & 85 & 123 & 127 & 132 & 138 & 190 & 203 & 233 & 233 \\
\hline Asterix & - & 68 & 62 & 93 & 103 & 139 & 153 & 178 & 187 & 244 & 285 & 329 & 422 \\
\hline Atlantic & - & 84 & 70 & 113 & 137 & 171 & 167 & 195 & 197 & 282 & 309 & 367 & 455 \\
\hline Markies & - & 48 & 53 & 67 & 102 & 123 & 148 & 148 & 158 & 224 & 258 & 291 & 359 \\
\hline Mondial & - & 39 & 57 & 67 & 98 & 95 & 117 & 127 & 135 & 162 & 228 & 248 & 303 \\
\hline \multicolumn{14}{|c|}{ Folhas } \\
\hline Ágata & - & 62 & 98 & 135 & 294 & 505 & 338 & 557 & 491 & 587 & 450 & 504 & 551 \\
\hline Asterix & - & 61 & 118 & 146 & 301 & 440 & 334 & 463 & 526 & 605 & 485 & 488 & 591 \\
\hline Atlantic & - & 88 & 152 & 175 & 442 & 469 & 408 & 563 & 530 & 603 & 480 & 413 & 491 \\
\hline Markies & - & 58 & 140 & 135 & 433 & 484 & 371 & 529 & 610 & 619 & 566 & 464 & 539 \\
\hline Mondial & - & 44 & 94 & 114 & 414 & 445 & 324 & 351 & 484 & 450 & 432 & 373 & 459 \\
\hline & \multicolumn{13}{|c|}{ Tubérculos } \\
\hline Ágata & - & - & - & 16 & 24 & 26 & 12 & 14 & 11 & 9 & 14 & 14 & 12 \\
\hline Asterix & - & - & - & 13 & 22 & 26 & 14 & 16 & 13 & 9 & 12 & 10 & 12 \\
\hline Atlantic & - & - & - & 13 & 21 & 20 & 12 & 14 & 10 & 12 & 13 & 12 & 15 \\
\hline Markies & - & - & - & 14 & 23 & 25 & 15 & 16 & 13 & 12 & 14 & 13 & 13 \\
\hline Mondial & - & - & - & 19 & 22 & 24 & 15 & 15 & 13 & 9 & 9 & 10 & 13 \\
\hline
\end{tabular}



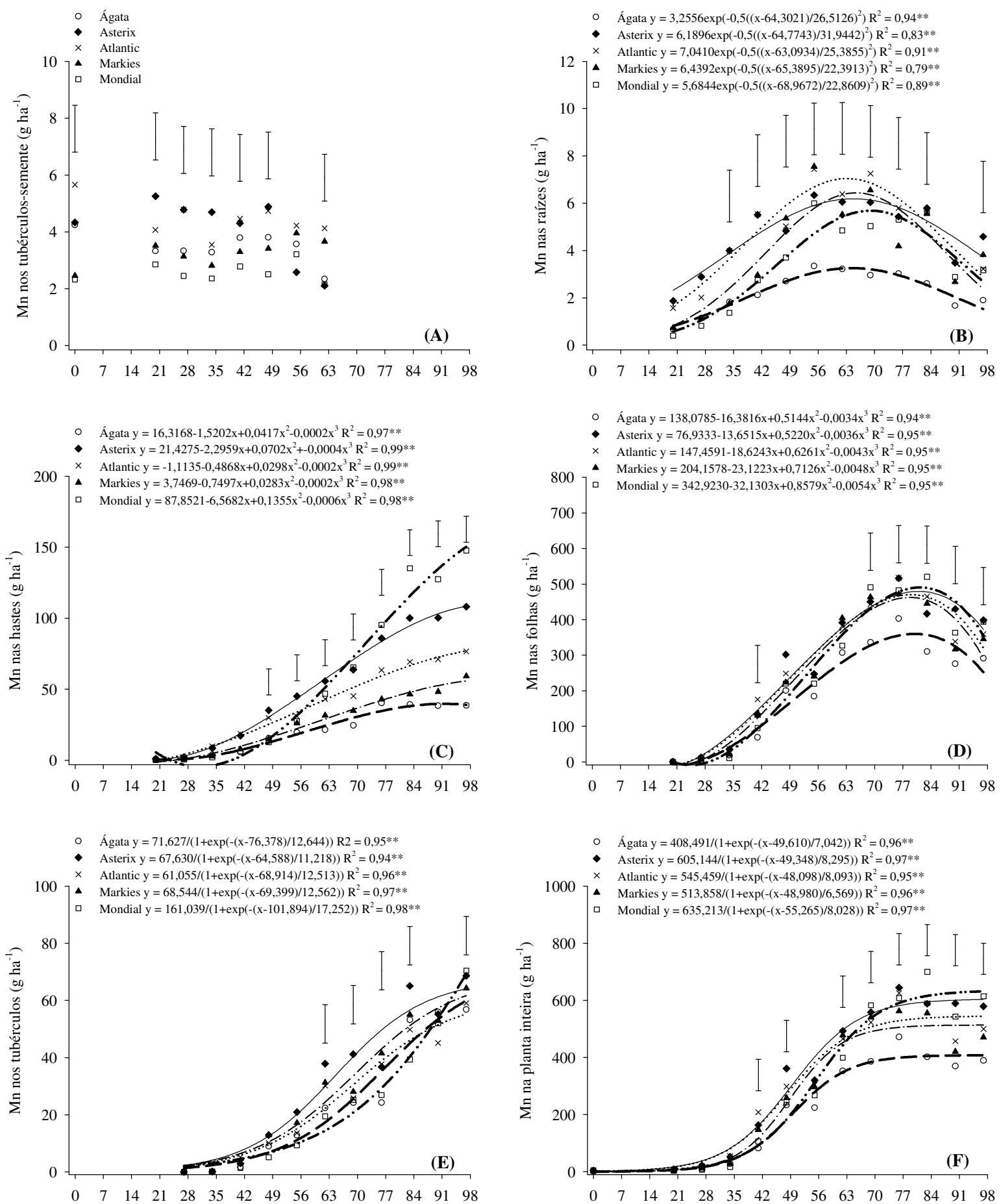

Dias após o plantio

Figura 26. Quantidade de Mn nos tubérculos-semente (A), raízes (B), hastes (C), folhas (D), tubérculos $(\mathrm{E})$ e na planta inteira $(\mathrm{F})$ de cultivares de batata ao longo do ciclo. ** significativo a $1 \%$ de probabilidade pelo teste F. Barras verticais indicam o valor de DMS pelo teste Tukey a $5 \%$ de probabilidade. 
Nas hastes, os acúmulos de Mn não diferiram entre as cultivares da emergência até aos 41 DAP (Figura 26C). No entanto, a partir dos 48 DAP as quantidades de Mn acumuladas pelas hastes intensificaram-se e diferiram entre as cultivares. Dos 48 aos 69 DAP, os acúmulos de Mn nas hastes da cultivar Asterix foram superiores aos observados nas cultivares Ágata e Markies. A partir dos 76 DAP, quando houve rápido acúmulo de Mn nas hastes das cultivares Mondial e Atlantic, estas passaram a acumular mais Mn em suas hastes quando comparadas à Ágata e Markies. No final do ciclo, os maiores acúmulos de Mn nas hastes ocorreram na seguinte ordem decrescente: Mondial (150,3 $\left.\mathrm{g} \mathrm{ha}^{-1}\right)$, Asterix $(108,4 \mathrm{~g} \mathrm{ha}$ $\left.{ }^{1}\right)$, Atlantic (77,0 $\left.\mathrm{g} \mathrm{ha}^{-1}\right)$, Markies $\left(56,0 \mathrm{~g} \mathrm{ha}^{-1}\right)$ e Ágata $\left(39,8 \mathrm{~g} \mathrm{ha}^{-1}\right)$.

As quantidades de MS acumuladas nas hastes das cultivares Atlantic, Ágata e Markies, no final do ciclo, foram semelhantes (Figura 5C), porém, Atlantic acumulou maiores quantidades de Mn nas hastes em comparação a Ágata e Markies (Figura 26C), o que é resultado dos maiores teores desse elemento nas hastes da Atlantic (Tabela 34).

Os acúmulos de Mn nas folhas foram ajustados a modelos cúbicos de regressão (Figura 26D). De maneira geral, em todas as cultivares os acúmulos de Mn nas folhas foram crescentes e não diferiram entre si desde a emergência até aos 62 DAP. Aos 69 e 83 DAP, os menores acúmulos foliares de Mn foram observados na cultivar Ágata, no entanto, aos 76, 90 e 97 apenas a cultivar Asterix apresentou acúmulos foliares de Mn superiores aos obtidos em Ágata. Nas demais cultivares, os acúmulos de Mn nas folhas foram semelhantes durante todo o ciclo, o que ocorreu devido aos menores teores de Mn obtidos na cultivar Mondial entre 69 e 83 DAP (Tabela 34), pois nesse período a MS foliar dessa cultivar foi significativamente superior à observada nas demais cultivares (Figura 5D). As quantidades máximas de Mn acumuladas nas folhas foram estimadas em 359,9, 479,5, 470,1, 462,3 e 490,5 $\mathrm{g} \mathrm{ha}^{-1} \mathrm{e}$, ocorreram aos 80, 80, 79, 78 e 81 DAP nas cultivares Ágata, Asterix, Atlantic, Markies e Mondial, respectivamente (Figura 26D).

Nos tubérculos, as quantidades acumuladas de Mn foram semelhantes até aos 55 DAP (Figura 26E). Aos 62 DAP a cultivar Asterix apresentou acúmulos de Mn nos tubérculos maiores que as cultivares Ágata e Mondial. Na avaliação seguinte, (69 DAP) as quantidades de Mn acumuladas nos tubérculos da cultivar Asterix tornaram-se superiores também às obtidas na cultivar Atlantic. Esse maior acúmulo de Mn nos tubérculos da cultivar 
Asterix nessa época está relacionado com a ocorrência das maiores taxas diárias de acúmulo de Mn nos tubérculos dessa cultivar por volta dos 64 DAP (Figura 27A e Tabela 35).
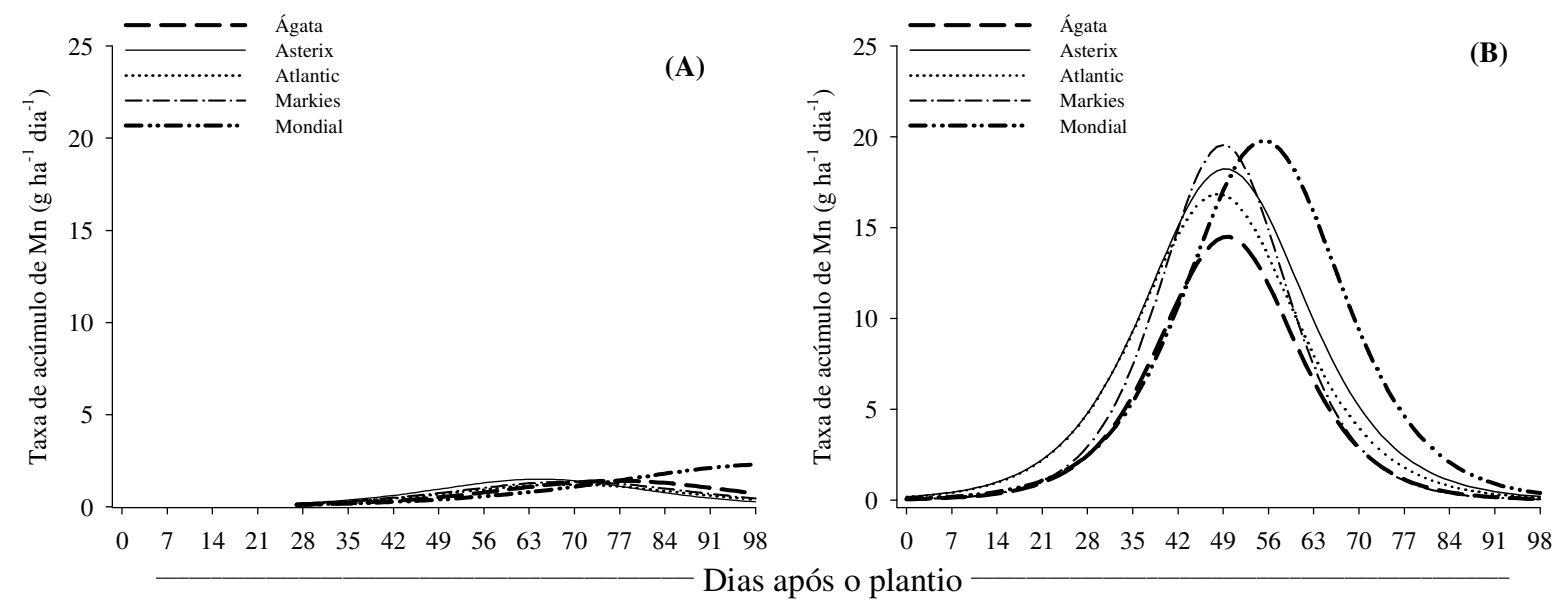

Figura 27. Taxa de acúmulo de Mn nos tubérculos (A) e nas plantas (B) de cultivares de batata ao longo do ciclo.

Tabela 35. Quantidade máxima de Mn acumulada, taxa diária máxima de acúmulo e época de maior taxa de acúmulo de Mn nos tubérculos e nas plantas de cultivares de batata.

\begin{tabular}{lcccccc}
\hline Cultivares & $\begin{array}{c}\text { Acúmulo } \\
\text { máximo no } \\
\text { tubérculo }\end{array}$ & $\begin{array}{c}\text { Taxa } \\
\text { máxima de } \\
\text { acúmulo no } \\
\text { tubérculo }\end{array}$ & $\begin{array}{c}\text { Época de } \\
\text { maior taxa } \\
\text { de acúmulo } \\
\text { no tubérculo }\end{array}$ & $\begin{array}{c}\text { Acúmulo } \\
\text { máximo na } \\
\text { planta }\end{array}$ & $\begin{array}{c}\text { Taxa } \\
\text { máxima de } \\
\text { acúmulo na } \\
\text { planta }\end{array}$ & $\begin{array}{c}\text { Época de } \\
\text { maior taxa de } \\
\text { acúmulo na } \\
\text { planta }\end{array}$ \\
\hline Ágata & $\mathrm{g} \mathrm{ha}^{-1}$ & $\mathrm{~g} \mathrm{ha}^{-1} \mathrm{dia}^{-1}$ & $\begin{array}{c}\mathrm{DAP} \\
\mathrm{g} \mathrm{ha}^{-1}\end{array}$ & $\mathrm{~g} \mathrm{ha}^{-1} \mathrm{dia}^{-1}$ & $\mathrm{DAP}$ \\
Asterix & 60 & 1,41 & 76 & 408 & 14,49 & 50 \\
Atlantic & 64 & 1,51 & 64 & 603 & 18,23 & 49 \\
Markies & 55 & 1,22 & 69 & 544 & 16,84 & 48 \\
Mondial & 62 & 1,36 & 69 & 513 & 19,55 & 49 \\
\hline
\end{tabular}

No final do ciclo, os acúmulos máximos estimados de Mn nos tubérculos foram de 60, 64, 55, 62 e $69 \mathrm{~g} \mathrm{ha}^{-1}$ nas cultivares Ágata, Asterix, Atlantic, Markies e Mondial, respectivamente (Figura 26E e Tabela 35). Nessa época as quantidades de Mn acumuladas nos tubérculos representaram aproximadamente $14,7 \%$ na cultivar Ágata e em torno de 10 a 12\% nas demais cultivares (Figura 26E e Tabela 35). Esse baixo acúmulo de Mn nos tubérculos que foi bem inferior à quantidade acumulada nas folhas (Figura 26), pode ser explicado pelas baixas taxas de acumulação desse elemento nos tubérculos (Figura 27A e 
Tabela 35). Isso ocorre devido a pequena redistribuição do Mn dentro da planta, pois, após absorvido, esse elemento move-se livremente via corrente transpiratória e acumula-se em certos órgãos das plantas como as folhas (MALAVOLTA, 1980; MALAVOLTA, 2006), de modo que, o pequeno transporte que ocorre via floema é quem promove a baixa concentração desse elemento em frutos, sementes e órgãos de reserva (DECHEN; NACHTIGALL, 2006), que neste caso são os tubérculos.

As quantidades totais de $\mathrm{Mn}$ acumuladas pelas plantas inteiras das cultivares de batata foram semelhantes durante a fase de crescimento vegetativo (Figura 26F). Nesse período, houve baixa exigência por esse elemento em todas as cultivares, uma vez que, as taxas diárias de absorção foram baixas e todas as cultivares tinham absorvido menos de $15 \%$ da quantidade total (Figura 27B e Tabela 36). Aos 41 e 48 DAP o acúmulo de Mn apresentado pelas plantas da cultivar Ágata foi inferior ao obtido nas cultivares Atlantic e Asterix, respectivamente. Esse menor acúmulo de Mn na cultivar Ágata durante esse período, está relacionado com as menores taxas de absorção apresentadas por essa cultivar nessa época (Figura 27B). O período de maior exigência em Mn por todas as cultivares ocorreu no início da fase de enchimento de tubérculos, quando observou-se a época de maior taxa de absorção desse elemento e as cultivares absorveram entre $56 \%$ e $65 \%$ da quantidade total (Figura 27B e Tabelas 35 e 36$)$.

Tabela 36. Percentual de Mn acumulado pelas plantas em cada fase do desenvolvimento das cultivares de batata (valores obtidos nas equações ajustadas).

\begin{tabular}{|c|c|c|c|c|c|}
\hline \multirow{3}{*}{ Cultivares } & \multicolumn{5}{|c|}{ Dias após o plantio/Fase da cultura } \\
\hline & $0-34$ & $35-41$ & $42-62$ & $63-90$ & 91-97 \\
\hline & Crescimento vegetatıvo & I uberızaçao & Enchim & uberculos & Maturação \\
\hline Ágata & 10 & 13 & 63 & 14 & 0 \\
\hline Asterix & 14 & 13 & 56 & 17 & 0 \\
\hline Atlantic & 15 & 14 & 56 & 15 & 0 \\
\hline Markies & 10 & 13 & 65 & 12 & 0 \\
\hline Mondial & 7 & 7 & 56 & 29 & 1 \\
\hline
\end{tabular}

No geral, a partir dos 69 DAP até o final do ciclo, as cultivares Asterix, Atlantic e Mondial apresentaram acúmulos de Mn superiores aos observados na cultivar Ágata (Figura 26F). Essas diferenças entre a quantidade de Mn acumulada pelas 
cultivares devem-se ao fato das taxas diárias de absorção de Mn nas cultivares Asterix, Atlantic e Mondial terem sido superiores àquelas observadas em Ágata (Figura 27B e Tabela $35)$.

Os acúmulos máximos estimados de $\mathrm{Mn}$, no final do ciclo, foram de 408, 603, 544, 513 e $632 \mathrm{~g} \mathrm{ha}^{-1}$ nas cultivares Ágata, Asterix, Atlantic, Markies e Mondial, respectivamente (Figura 26F e Tabela 35). Yorinori (2003) em estudo sobre o crescimento e o acúmulo de nutrientes pela batateira, cultivar Atlantic, obteve acúmulos totais de $\mathrm{Mn}$ de $250 \mathrm{~g}$ $\mathrm{ha}^{-1}$ (safra das águas) e $130 \mathrm{~g} \mathrm{ha}^{-1}$ (safra das secas) aos 84 e 57 DAP, respectivamente, os quais foram inferiores aos observados no presente trabalho. Verifica-se ainda que a época de maior taxa de absorção de Mn pelas plantas das cultivares de batata concentrou-se entre 48 e 55 DAP, no entanto, as taxas máximas de acúmulo de Mn nos tubérculos ocorridas entre 64 e 97 DAP foram em média 11 vezes menores que as taxas máximas de absorção, demonstrando que embora ocorra um período de maior absorção de Mn pelas plantas, esse elemento não é translocado em grandes quantidades para os tubérculos (Figura 27B e Tabela 35).

\subsubsection{Zinco}

Nos tubérculos-semente, raízes e hastes o teor de $\mathrm{Zn}$ aumentou gradativamente no decorrer do ciclo, no entanto, nos tubérculos os teores de $\mathrm{Zn}$ permaneceram relativamente constantes da tuberização até por volta dos 90 DAP, e aumentaram na última avaliação (Tabela 37). Nas folhas o comportamento foi diferente, ou seja, desde a emergência até o final do ciclo, no geral, foram observadas diminuições no teor desse elemento. Entre os órgãos das plantas observou-se que no final do ciclo os teores de $\mathrm{Zn}$ nas raízes e hastes apresentaram valores próximos, sendo seguidos das folhas e tubérculos.

Do plantio até a última avaliação as quantidades de $\mathrm{Zn}$ nos tubérculossemente sofreram diminuições (Figura 28A). No plantio as cultivares Asterix e Ágata apresentaram quantidade de $\mathrm{Zn}$ nos tubérculos-semente maiores que àquelas observadas em Mondial e Markies, porém, aos 20 DAP a redução do $\mathrm{Zn}$ dos tubérculos-semente das cultivares Asterix e Ágata fez com que a quantidade desse elemento contida nos tubérculossemente dessas cultivares se tornasse semelhante à obtida em Markies, mas superior a Mondial e Atlantic. Nas demais avaliações as quantidades desse elemento nos tubérculos-semente 
permaneceram semelhantes. Vale destacar que embora a cultivar Atlantic tenha apresentado maior MS de tubérculos-semente que Ágata (Figura 5A), seu conteúdo de Zn foi menor (Figura 28A), devido principalmente aos menores teores desse elemento observados nos tubérculos-semente de Atlantic em comparação à Ágata (Tabela 37).

Tabela 37. Teor de Zn em cada parte das plantas de cultivares de batata durante o ciclo da cultura.

\begin{tabular}{|c|c|c|c|c|c|c|c|c|c|c|c|c|c|}
\hline \multirow{2}{*}{ Cultivares } & \multicolumn{13}{|c|}{ Dias após o plantio } \\
\hline & 0 & 20 & 27 & 34 & 41 & 48 & 55 & 62 & 69 & 76 & 83 & 90 & 97 \\
\hline $\begin{array}{l}\text { mg kg-1 } \\
\text { Tubérculos-semente }\end{array}$ & \multicolumn{13}{|c|}{$\mathrm{mg} \mathrm{kg}^{-1}$} \\
\hline Ágata & 26 & 26 & 14 & 26 & 36 & 41 & 37 & 32 & - & - & - & - & - \\
\hline Asterix & 22 & 23 & 14 & 29 & 32 & 32 & 42 & 34 & - & - & - & - & - \\
\hline Atlantic & 16 & 14 & 11 & 21 & 28 & 28 & 38 & 25 & - & - & - & - & - \\
\hline Markies & 20 & 22 & 12 & 24 & 23 & 27 & 36 & 27 & - & - & - & - & - \\
\hline Mondial & 24 & 17 & 17 & 25 & 28 & 31 & 23 & 26 & - & - & - & - & - \\
\hline \multicolumn{14}{|c|}{ Raízes } \\
\hline Ágata & - & 88 & 118 & 106 & 138 & 128 & 127 & 103 & 109 & 97 & 126 & 113 & 132 \\
\hline Asterix & - & 88 & 116 & 103 & 123 & 128 & 124 & 100 & 107 & 109 & 110 & 111 & 118 \\
\hline Atlantic & - & 83 & 112 & 88 & 120 & 141 & 130 & 105 & 114 & 104 & 120 & 117 & 114 \\
\hline Markies & - & 79 & 124 & 83 & 115 & 130 & 121 & 97 & 96 & 105 & 113 & 120 & 129 \\
\hline Mondial & - & 80 & 121 & 99 & 131 & 129 & 143 & 111 & 108 & 116 & 107 & 107 & 118 \\
\hline \multicolumn{14}{|c|}{ Hastes } \\
\hline Ágata & - & 41 & 66 & 78 & 104 & 90 & 94 & 93 & 78 & 91 & 95 & 90 & 112 \\
\hline Asterix & - & 42 & 75 & 91 & 106 & 103 & 99 & 87 & 78 & 82 & 72 & 79 & 102 \\
\hline Atlantic & - & 57 & 89 & 111 & 119 & 128 & 130 & 131 & 116 & 143 & 135 & 142 & 162 \\
\hline Markies & - & 39 & 84 & 107 & 127 & 141 & 146 & 139 & 133 & 152 & 150 & 152 & 168 \\
\hline Mondial & - & 34 & 75 & 99 & 119 & 122 & 132 & 114 & 108 & 109 & 121 & 143 & 133 \\
\hline \multicolumn{14}{|c|}{ Folhas } \\
\hline Ágata & - & 79 & 69 & 67 & 91 & 79 & 93 & 53 & 50 & 57 & 55 & 85 & 75 \\
\hline Asterix & - & 70 & 54 & 64 & 79 & 66 & 75 & 44 & 45 & 42 & 44 & 50 & 56 \\
\hline Atlantic & - & 83 & 68 & 64 & 90 & 73 & 77 & 53 & 56 & 47 & 54 & 62 & 70 \\
\hline Markies & - & 85 & 65 & 63 & 87 & 79 & 90 & 56 & 61 & 50 & 63 & 63 & 77 \\
\hline Mondial & - & 87 & 80 & 94 & 108 & 100 & 112 & 72 & 72 & 58 & 56 & 69 & 88 \\
\hline \multicolumn{14}{|c|}{ Tubérculos } \\
\hline Ágata & - & - & - & 48 & 43 & 40 & 30 & 23 & 31 & 23 & 31 & 35 & 55 \\
\hline Asterix & - & - & - & 36 & 33 & 33 & 27 & 23 & 33 & 29 & 31 & 41 & 54 \\
\hline Atlantic & - & - & - & 29 & 28 & 23 & 20 & 21 & 26 & 19 & 24 & 33 & 51 \\
\hline Markies & - & - & - & 40 & 36 & 31 & 26 & 25 & 35 & 34 & 30 & 46 & 49 \\
\hline Mondial & - & - & - & 50 & 46 & 38 & 35 & 39 & 26 & 28 & 32 & 42 & 57 \\
\hline
\end{tabular}



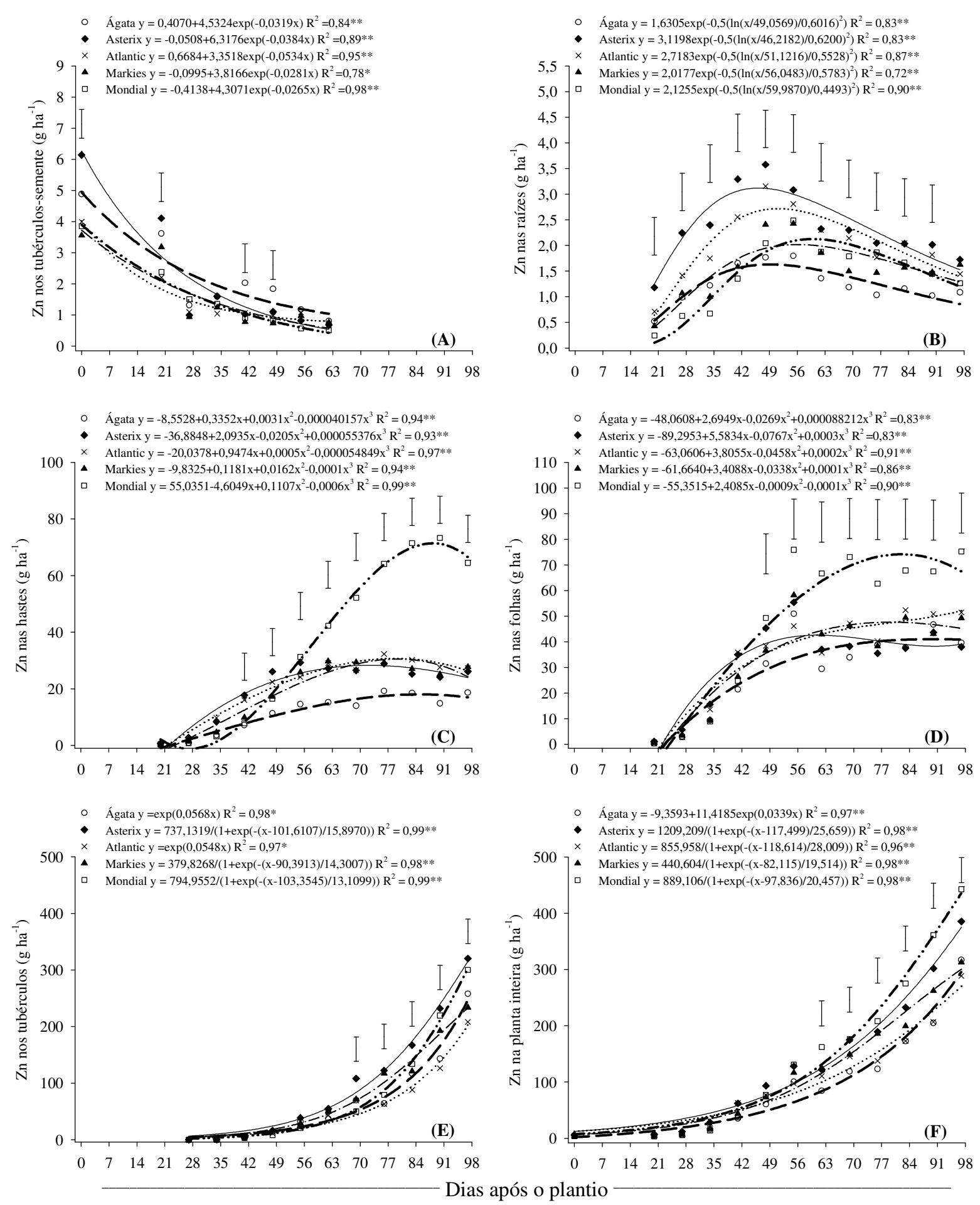

Figura 28. Quantidade de Zn nos tubérculos-semente (A), raízes (B), hastes (C), folhas (D), tubérculos (E) e na planta inteira $(\mathrm{F})$ de cultivares de batata ao longo do ciclo. * e ** significativo a $5 \%$ e $1 \%$ de probabilidade pelo teste $\mathrm{F}$. Barras verticais indicam o valor de DMS pelo teste Tukey a 5\% de probabilidade. 
Os acúmulos de $\mathrm{Zn}$ nas raízes foram crescentes desde a emergência até entre 46 e 56 DAP, quando as cultivares Asterix, Atlantic, Markies e Ágata atingiram as quantidades máximas estimadas de 3,12, 2,72, 2,02 e 1,63 $\mathrm{g} \mathrm{ha}^{-1}$, respectivamente (Figura 28B). Na cultivar Mondial, o acúmulo de Zn nas raízes inicialmente foi mais lento que nas cultivares Asterix e Atlantic até aos 48 DAP, no entanto, após esse período a cultivar Mondial continuou acumulando $\mathrm{Zn}$ constantemente nas raízes até atingir o acúmulo máximo estimado de 2,1 $\mathrm{g} \mathrm{ha}^{-1}$ por volta dos $60 \mathrm{DAP}$, quando, tornou-se semelhante as cultivares Asterix e Atlantic. De maneira geral, da emergência até aos 48 DAP, os acúmulos de Zn nas raízes das cultivares Asterix e Atlantic foram na maioria das vezes superior ao de todas as cultivares estudadas. No entanto, entre 55 e 90 DAP as quantidades desse elemento acumuladas nas raízes dessas cultivares superaram apenas os valores obtidos na cultivar Ágata, uma vez que, a partir dos 48 DAP o acúmulo de Zn nas raízes da cultivar Ágata foi sempre decrescente.

As quantidades de $\mathrm{Zn}$ acumuladas nas hastes apresentaram ajustes a modelos cúbicos de regressão (Figura 28C). Os acúmulos máximos de $\mathrm{Zn}$ nas hastes foram de 18,0, 28,3, 30,7, 30,5 e 71,4 $\mathrm{g} \mathrm{ha}^{-1}$ e, ocorreram aos 85, 72, 78, 79 e 88 DAP nas cultivares Ágata, Asterix, Atlantic, Markies e Mondial, respectivamente. Da emergência até aos 27 DAP os acúmulos de $\mathrm{Zn}$ nas hastes foram semelhantes entre todas as cultivares, mas, entre os 55 e 90 DAP os menores acúmulos desse elemento foram observados nas hastes da cultivar Ágata. Aos 55 DAP o acúmulo de Zn nas hastes das cultivares Mondial, Asterix, Atlantic e Markies foram semelhantes. A partir dos 62 DAP houve um aumento intenso da quantidade de $\mathrm{Zn}$ acumulada nas hastes da cultivar Mondial, o que proporcionou quantidades acumuladas maiores que nas demais cultivares. Embora a MS de hastes da cultivar Asterix tenha sido maior que a observada nas cultivares Atlantic e Markies (Figura 5C), os acúmulos de Zn nas hastes dessas cultivares foram semelhantes (Figura 28C), o que pode ser explicado pelos menores teores de $\mathrm{Zn}$ observados nas hastes da cultivar Asterix (Tabela 37).

Da emergência até aos 41 DAP as quantidades de $\mathrm{Zn}$ acumuladas nas folhas aumentaram sem diferir entre as cultivares, porém, a partir dos 55 DAP, houve grande aumento na quantidade acumulada nas folhas da cultivar Mondial, a qual, apresentou acúmulo foliar de $\mathrm{Zn}$ superior à todas as cultivares, até o final do ciclo (Figura 28D). Nessa mesma época, nas demais cultivares as quantidades desse elemento acumuladas nas folhas mantiveram-se semelhantes. Os maiores acúmulos de $\mathrm{Zn}$ nas folhas das cultivares estudadas 
ocorreram aos 61, 79, 82, 90 e 97 DAP e foram de aproximadamente 42,6, 47,7, 74,2, 41,0 e $52,2 \mathrm{~g} \mathrm{ha}^{-1}$, respectivamente, para as cultivares Asterix, Markies, Mondial, Ágata e Atlantic.

Nos tubérculos, os acúmulos de Zn foram semelhantes até aos 62 DAP (Figura 28E). O acúmulo de Zn nos tubérculos da cultivar Asterix foi maior que o observado na cultivar Mondial aos 69 DAP e, superior ao observado nas cultivares Ágata e Atlantic aos 76 DAP. Esse maior acúmulo de Zn na cultivar Asterix, deveu-se ao fato que desde o início da tuberização as taxas de acúmulo de $\mathrm{Zn}$ nos tubérculos dessa cultivar foram superiores às obtidas nas cultivares Mondial, Ágata e Atlantic (Figura 29A). Como a partir dos 76 DAP as taxas de acúmulo de $\mathrm{Zn}$ nos tubérculos da cultivar Atlantic permaneceram inferiores as taxas observadas em Asterix (Figura 29A), fica evidente o fato da cultivar Asterix ter acumulado mais $\mathrm{Zn}$ nos tubérculos durante esse período, quando comparada à Atlantic (Figura 28E).

No final do ciclo, os maiores acúmulos de Zn foram observados nos tubérculos das cultivares Asterix e Mondial, os quais foram superiores aos das cultivares Markies e Atlantic. Nessa época, os acúmulos máximos estimados de Zn nos tubérculos das cultivares foram de 247, 315, 203, 233 e $303 \mathrm{~g} \mathrm{ha}^{-1}$ nas cultivares Ágata, Asterix, Atlantic, Markies e Mondial, respectivamente (Figura 28E e Tabela 38). A quantidade de Zn acumulada nos tubérculos no final do ciclo correspondeu a aproximadamente $84 \%$ do total absorvido nas cultivares Ágata e Asterix e, entre 70\% e 78\% do total absorvido nas demais cultivares (Figura 28E e Tabela 38). Essa alta proporção de acúmulo de Zn nos tubérculos está relacionada com as altas taxas de acúmulo desse nutriente nos tubérculos ocorridas na fase final do ciclo (Figura 29A e Tabela 38). Segundo Dechen e Nachtigall (2006) alguns autores consideram o $\mathrm{Zn}$ como sendo altamente móvel na planta, enquanto outros o consideram de mobilidade intermediária, mas ao que parece, na batateira tudo indica que esse elemento possa ser redistribuído facilmente, uma vez que, as taxas máximas de acúmulo de Zn nos tubérculos chegaram a ser maiores que as taxas máximas de absorção pelas plantas. 

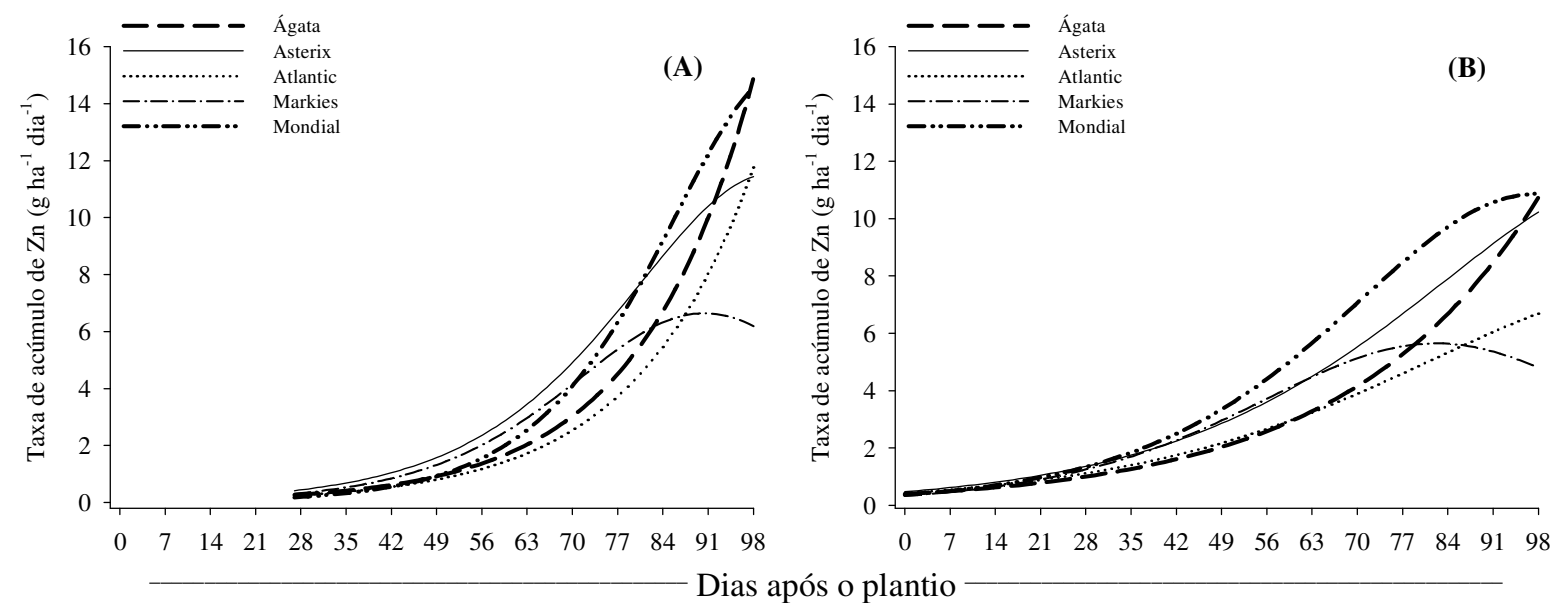

Figura 29. Taxa de acúmulo de Zn nos tubérculos (A) e nas plantas (B) de cultivares de batata ao longo do ciclo.

Tabela 38. Quantidade máxima de Zn acumulada, taxa diária máxima de acúmulo e época de maior taxa de acúmulo de $\mathrm{Zn}$ nos tubérculos e nas plantas de cultivares de batata.

\begin{tabular}{lcccccc}
\hline Cultivares & $\begin{array}{c}\text { Acúmulo } \\
\text { máximo no } \\
\text { tubérculo }\end{array}$ & $\begin{array}{c}\text { Taxa } \\
\text { máxima de } \\
\text { acúmulo no } \\
\text { tubérculo }\end{array}$ & $\begin{array}{c}\text { Época de } \\
\text { maior taxa } \\
\text { de acúmulo } \\
\text { no tubérculo }\end{array}$ & $\begin{array}{c}\text { Acúmulo } \\
\text { máximo na } \\
\text { planta }\end{array}$ & $\begin{array}{c}\text { Taxa } \\
\text { máxima de } \\
\text { acúmulo na } \\
\text { planta }\end{array}$ & $\begin{array}{c}\text { Época de } \\
\text { maior taxa de } \\
\text { acúmulo na } \\
\text { planta }\end{array}$ \\
\hline Ágata & $\mathrm{g} \mathrm{ha}^{-1}$ & $\mathrm{~g} \mathrm{ha}^{-1} \mathrm{dia}^{-1}$ & $\begin{array}{c}\text { DAP } \\
\mathrm{ph}^{-1} \mathrm{dia}^{-1}\end{array}$ & $\mathrm{~g} \mathrm{ha}^{-1}$ & $\mathrm{~g} \mathrm{hAP}^{-1}$ \\
Asterix & 247 & 14,26 & 97 & 295 & 10,37 & 97 \\
Atlantic & 315 & 11,38 & 97 & 375 & 10,08 & 97 \\
Markies & 203 & 11,32 & 97 & 270 & 6,60 & 97 \\
Mondial & 233 & 6,64 & 90 & 300 & 5,64 & 82 \\
\hline
\end{tabular}

Considerando a planta inteira, verifica-se que os acúmulos de $\mathrm{Zn}$ das cultivares de batata não diferiram até aos 55 DAP (Figura 28F). Da emergência até o final da fase de tuberização, houve baixa exigência em $\mathrm{Zn}$, uma vez que as cultivares absorveram entre 12 e $19 \%$ do total de Zn extraído, o que provavelmente está relacionado com as pequenas taxas diárias de absorção observadas nessa época (Tabela 39 e Figura 29 B). Mesmo no início da fase de enchimento de tubérculos, a absorção de $\mathrm{Zn}$, foi pequena em todas cultivares, e a cultivar que absorveu as maiores proporções em relação à quantidade total de $\mathrm{Zn}$, foi Markies (Tabela 39). 
Tabela 39. Percentual de $\mathrm{Zn}$ acumulado pelas plantas em cada fase do desenvolvimento das cultivares de batata (valores obtidos nas equações ajustadas).

\begin{tabular}{|c|c|c|c|c|c|}
\hline \multirow{3}{*}{ Cultivares } & \multicolumn{5}{|c|}{ Dias após o plantio/Fase da cultura } \\
\hline & $0-34$ & $35-41$ & $42-62$ & $63-90$ & 91-97 \\
\hline & Crescimento vegetativo & Tuberização & Enchimen & bérculos & Maturação \\
\hline Ágata & 9 & 3 & 16 & 50 & 22 \\
\hline Asterix & 12 & 4 & 18 & 49 & 17 \\
\hline Atlantic & 15 & 4 & 18 & 47 & 16 \\
\hline Markies & 11 & 4 & 23 & 50 & 12 \\
\hline Mondial & 9 & 3 & 18 & 53 & 17 \\
\hline
\end{tabular}

Diferenças entre cultivares, quanto ao acúmulo de $\mathrm{Zn}$, somente foram observadas a partir de 62 DAP, quando a cultivar Mondial apresentou acúmulo de Zn superior ao observado nas cultivares Ágata e Atlantic (Figura 28F). De 69 DAP em diante as cultivares Mondial e Asterix acumularam Zn em maiores quantidades que Ágata e Atlantic. Os maiores acúmulos de $\mathrm{Zn}$ observados nas cultivares Mondial e Asterix ocorreram devido ao fato das taxas de diárias de absorção de Zn terem sido superiores àquelas observadas nas cultivares Ágata e Atlantic (Figura 29B e Tabela 38).

A absorção de $\mathrm{Zn}$ em todas as cultivares ocorreu em maiores proporções no final da fase de enchimento de tubérculos e durante a fase de maturação, pois, nesse período observou-se os maiores aumentos no acúmulo de $\mathrm{Zn}$ (Figura 28F), as maiores taxas de absorção (Figura 29B e Tabela 38) e foi quando ocorreu a maior parte da absorção que variou entre 62\% (Markies) e 72\% (Ágata) do total de Zn extraído (Tabela 39). No final do ciclo, os acúmulos máximos de Zn foram estimados em 295, 375, 270, 300 e $435 \mathrm{~g} \mathrm{ha}^{-1}$ nas cultivares Ágata, Asterix, Atlantic, Markies e Mondial, respectivamente (Figura 28F e Tabela 38). Yorinori (2003) observou acúmulos totais de $\mathrm{Zn}$ de $156,8 \mathrm{~g} \mathrm{ha}^{-1}$ (safra das águas) e 124,6 $\mathrm{g} \mathrm{ha}^{-1}$ (safra das secas) aos 111 e 90 DAP, respectivamente, na cultivar Atlantic, os quais foram inferiores aos encontrados neste estudo. 


\subsection{Porcentagem de matéria seca e exportação de nutrientes}

As cultivares Atlantic, Markies e Asterix apresentaram as maiores porcentagens de MS nos tubérculos (Tabela 40). Tubérculos com maiores teores de carboidratos e com menores teores de água como os das cultivares Atlantic, Markies e Asterix (Tabela 40) são mais adequados à fritura e ao preparo de purês (PEREIRA et al., 2005), favorecem o rendimento da fritura e a produção de chips, proporcionando menor retenção de óleo e garantindo a crocância do produto final (MELO, 1999). Cultivares com menor porcentagem de MS em seus tubérculos como Ágata e Mondial (Tabela 40), são mais firmes no cozimento, sendo indicadas para a preparação de pratos assados onde é essencial a manutenção de sua forma (PEREIRA, 1987).

Quanto ao teor de macronutrientes, observa-se que a cultivar Markies sempre esteve entre as cultivares que apresentaram os maiores teores de $\mathrm{N}, \mathrm{P}, \mathrm{K}, \mathrm{Mg}$ e $\mathrm{S}$ nos tubérculos (Tabela 40). Os teores de Ca não diferiram entre as cultivares estudadas, enquanto que a cultivar Ágata juntamente com Markies apresentou os maiores teores de $\mathrm{Mg}$ em seus tubérculos. Com relação aos teores de $\mathrm{S}$ nos tubérculos, observou-se diferenças apenas entre as cultivares Ágata, Asterix e Mondial (Tabela 40).

Tabela 40. Porcentagem de MS e teor de macronutrientes nutrientes nos tubérculos de cultivares de batata na colheita final.

\begin{tabular}{lcclllll}
\hline Cultivares & Matéria seca & $\mathrm{N}$ & $\mathrm{P}$ & $\mathrm{K}$ & $\mathrm{Ca}$ & $\mathrm{Mg}$ & $\mathrm{S}$ \\
\cline { 2 - 8 } & $\%$ & & \multicolumn{5}{c}{$\mathrm{g} \mathrm{kg}^{-1} \mathrm{de} \mathrm{MS}{ }^{(1)}$} \\
Ágata & $14,1 \mathrm{c}$ & $13 \mathrm{ab}$ & $2,6 \mathrm{ab}$ & $31 \mathrm{~b}$ & $0,4 \mathrm{a}$ & $1,4 \mathrm{a}$ & $1,1 \mathrm{a}$ \\
Asterix & $16,7 \mathrm{~b}$ & $13 \mathrm{ab}$ & $2,3 \mathrm{~b}$ & $33 \mathrm{~b}$ & $0,4 \mathrm{a}$ & $1,2 \mathrm{ab}$ & $0,7 \mathrm{~b}$ \\
Atlantic & $19,0 \mathrm{a}$ & $11 \mathrm{~b}$ & $2,4 \mathrm{ab}$ & $33 \mathrm{~b}$ & $0,4 \mathrm{a}$ & $1,1 \mathrm{~b}$ & $0,9 \mathrm{ab}$ \\
Markies & $17,2 \mathrm{ab}$ & $14 \mathrm{a}$ & $2,7 \mathrm{a}$ & $36 \mathrm{a}$ & $0,5 \mathrm{a}$ & $1,3 \mathrm{a}$ & $0,8 \mathrm{ab}$ \\
Mondial & $13,3 \mathrm{c}$ & $11 \mathrm{~b}$ & $2,4 \mathrm{ab}$ & $32 \mathrm{~b}$ & $0,5 \mathrm{a}$ & $1,0 \mathrm{~b}$ & $0,7 \mathrm{~b}$ \\
CV \% & 5,7 & 8,4 & 6,2 & 3,6 & 22,4 & 8,7 & 19,6 \\
\hline
\end{tabular}

Médias seguidas de mesma letra nas colunas não diferem entre si pelo teste Tukey a 5\% de probabilidade.

${ }^{(1)}$ Valores expressos na matéria seca.

A maior exportação de $\mathrm{N}$ por área foi observada na cultivar Asterix, enquanto, as menores exportações desse elemento foram obtidas nas cultivares Mondial e Atlantic (Tabela 41). Yorinori (2003) observou exportação de $\mathrm{N}$ por área da ordem de $120 \mathrm{~kg}$ 
$\mathrm{ha}^{-1}$ (safra das águas) e $113 \mathrm{~kg} \mathrm{ha}^{-1}$ (safra das secas), as quais foram superiores às encontradas neste experimento. As maiores exportações por tonelada de tubérculos ocorreram nas cultivares Asterix, Atlantic e Markies e foram superiores às obtidas na cultivar Mondial. Feltran (2002) em estudo sobre a determinação das características agronômicas de cultivares de batata observou que a cultivar Mondial foi uma das que apresentou a menor exportação de $\mathrm{N}$ por tonelada de tubérculos, ficando em torno de $2,0 \mathrm{~kg} \mathrm{t}^{-1}$. No entanto, mesmo sendo considerada baixa por esse autor, essa exportação ainda foi maior que a obtida no presente estudo. Porém, de maneira geral, todas as cultivares mostraram valores de exportação de $\mathrm{N}$ por unidade produzida inferiores ao intervalo descrito por Fontes (1997b), o qual é de 3,0 a 5,0 kg de $\mathrm{N}$ por tonelada de tubérculos. Chama a atenção o fato de que mesmo a cultivar Mondial apresentando a maior produtividade de tubérculos juntamente com Asterix (Tabela 5), sua exportação de $\mathrm{N}$ tanto por área, como por unidade produzida (Tabela 41), foi uma das menores, o que é resultado das menores porcentagens de $\mathrm{MS}$ e dos menores teores de $\mathrm{N}$ em seus tubérculos (Tabela 40).

Tabela 41. Exportação por área e por tonelada de tubérculos dos macronutrientes N, P, K, Ca, $\mathrm{Mg}$ e S, nas cultivares de batata na colheita final.

\begin{tabular}{|c|c|c|c|c|c|c|}
\hline Cultivares & $\mathrm{N}$ & $\mathrm{P}$ & $\mathrm{K}$ & $\mathrm{Ca}$ & $\mathrm{Mg}$ & $S$ \\
\hline & \multicolumn{6}{|c|}{$\mathrm{kg} \mathrm{ha}^{-1(2)}$} \\
\hline Ágata & $69 \mathrm{ab}$ & $14 \mathrm{a}$ & $163 b$ & $2 \mathrm{a}$ & $7 \mathrm{ab}$ & $6 a$ \\
\hline Asterix & $88 \mathrm{a}$ & $15 \mathrm{a}$ & $220 \mathrm{a}$ & $3 \mathrm{a}$ & $8 \mathrm{a}$ & $5 \mathrm{a}$ \\
\hline Atlantic & $48 \mathrm{c}$ & $10 \mathrm{~b}$ & $143 b$ & $2 \mathrm{a}$ & $5 c$ & $4 a$ \\
\hline Markies & $68 \mathrm{ab}$ & $13 \mathrm{ab}$ & $178 b$ & $2 \mathrm{a}$ & $7 a b c$ & $4 a$ \\
\hline Mondial & $61 \mathrm{bc}$ & $13 \mathrm{ab}$ & $176 b$ & $3 a$ & $6 \mathrm{bc}$ & $4 a$ \\
\hline \multirow[t]{2}{*}{ CV \% } & 13,3 & 11,1 & 9,5 & 26,0 & 13,5 & 23,8 \\
\hline & \multicolumn{6}{|c|}{$\mathrm{kg} \mathrm{t}^{-1}$ de matéria fresca ${ }^{(2)}$} \\
\hline Ágata & $1,87 \mathrm{ab}$ & $0,37 \mathrm{ab}$ & $4,35 b$ & $0,10 \mathrm{a}$ & $0,20 \mathrm{a}$ & $0,17 \mathrm{ab}$ \\
\hline Asterix & $2,20 \mathrm{a}$ & $0,40 \mathrm{ab}$ & $5,52 \mathrm{a}$ & $0,10 \mathrm{a}$ & $0,20 \mathrm{a}$ & $0,12 \mathrm{ab}$ \\
\hline Atlantic & $2,12 \mathrm{a}$ & $0,47 a$ & $6,32 a$ & $0,10 \mathrm{a}$ & $0,20 \mathrm{a}$ & $0,20 \mathrm{a}$ \\
\hline Markies & $2,40 \mathrm{a}$ & $0,47 \mathrm{a}$ & $6,25 \mathrm{a}$ & $0,10 \mathrm{a}$ & $0,20 \mathrm{a}$ & $0,12 \mathrm{ab}$ \\
\hline Mondial & $1,50 \mathrm{~b}$ & $0,30 \mathrm{~b}$ & $4,30 \mathrm{~b}$ & $0,07 \mathrm{a}$ & $0,12 \mathrm{~b}$ & $0,10 \mathrm{~b}$ \\
\hline $\mathrm{CV} \%$ & 11,7 & 14,4 & 7,7 & 23,5 & 12,1 & 28,8 \\
\hline
\end{tabular}

Médias seguidas de mesma letra nas colunas não diferem entre si pelo teste Tukey a $5 \%$ de probabilidade. ${ }^{(1)}$ Valores expressos na matéria seca. ${ }^{(2)}$ Exportação de nutrientes em relação à produtividade total.

Quanto à exportação por área de $\mathrm{P}$, as cultivares Ágata e Asterix apresentaram os maiores valores enquanto o menor valor foi observado em Atlantic (Tabela 
41). Yorinori (2003) observou exportação de P pela cultivar Atlantic de $15 \mathrm{~kg} \mathrm{ha}^{-1}$ na safra das águas, a qual foi maior que a observada na mesma cultivar no presente ensaio, porém, semelhante à obtida na Asterix. Na exportação por unidade produzida, Atlantic e Markies apresentaram valores semelhantes e superiores aos obtidos para a Mondial. A exportação de $0,525 \mathrm{~kg} \mathrm{t}^{-1}$ obtida por Feltran (2002) para a cultivar Mondial, foi maior que a observada em todas as cultivares estudadas. No entanto, para todas as cultivares, os valores de exportação por tonelada estão dentro do intervalo de 0,3 a $0,5 \mathrm{~kg}$ de $\mathrm{P}$ por tonealada de tubérculos, relatado por Fontes (1997b).

A maior exportação por área de $\mathrm{K}$ foi observada na cultivar Asterix, que foi superior as demais (Tabela 41). Em todas as cultivares estudadas, a exportação de $\mathrm{K}$ por área foi superior à obtida por Yorinori (2003), na cutivar Atlantic (104 $\mathrm{kg} \mathrm{ha}^{-1}$ na safra das águas e $119 \mathrm{~kg} \mathrm{ha}^{-1}$ na safra das secas). As menores exportações por tonelada foram observadas nas cultivares Ágata e Mondial. Os valores de exportação de K de 4,78 $\mathrm{kg} \mathrm{t}^{-1}$ observados por Feltran (2002) nas cultivares IAC Aracy Ruiva e Remarka foram semelhantes aos observados nas cultivares Ágata e Mondial, porém, inferiores aos obtidos nas demais cultivares. Fontes (1999) relata que, de maneira geral, uma tonelada de tubérculos remove do solo $3,75 \mathrm{~kg}$ de $\mathrm{K}$. No entanto, neste ensaio observou-se valores maiores que os citados por este autor.

A exportação de Ca por área e por tonelada de tubérculos não diferiu entre as cultivares (Tabela 41). Nas cultivares Mondial e Atlantic a exportação de Ca por área foi semelhante à relatada por Yorinori (2003), na cultivar Atlantic, durante a safra das águas $\left(2,88 \mathrm{~kg} \mathrm{ha}^{-1}\right)$ e das secas $\left(1,77 \mathrm{~kg} \mathrm{ha}^{-1}\right)$. Já a exportação de Ca por tonelada foi maior que a obtida por Feltran (2002) nas cultivares Remarka $\left(0,068 \mathrm{~kg} \mathrm{t}^{-1}\right)$ e Solide $\left(0,020 \mathrm{~kg} \mathrm{t}^{-1}\right)$ e as observadas por Yorinori (2003), nas duas safras $\left(0,08 \mathrm{~kg} \mathrm{t}^{-1}\right.$ safra das águas e $0,07 \mathrm{~kg} \mathrm{t}^{-1}$ safra das secas).

Quanto ao Mg, houve diferença significativa na exportação por área, sendo que a maior exportação de $\mathrm{Mg}$ ocorreu em Asterix e as menores em Mondial e Atlantic (Tabela 41). A exportação por tonelada de tubérculos foi menor na cultivar Mondial. Yorinori (2003) observou exportações de $\mathrm{Mg}$ por área de $0,24 \mathrm{~kg} \mathrm{t}^{-1}$ (safra das águas) e $0,25 \mathrm{~kg} \mathrm{t}^{-1}$ (safra das secas), ou seja, um pouco maiores que as observadas no presente estudo. No entanto, em 
todas as cultivares a exportação ficou dentro do intervalo citado por Fontes (1997b) que é de 0,1 a $0,3 \mathrm{~kg} \mathrm{t}^{-1}$.

A exportação de S por área foi semelhante entre todas as cultivares. Já na exportação de $S$ por tonelada, a cultivar Mondial foi inferior à Atlantic (Tabela 41). Em todas as cultivares a exportação por tonelada foi inferior à obtida por Yorinori (2003) safra das águas $\left(0,24 \mathrm{~kg} \mathrm{t}^{-1}\right)$ e na safra das secas $\left(0,25 \mathrm{~kg} \mathrm{t}^{-1}\right)$, além de estarem bem abaixo do intervalo descrito por Fontes (1997b), como sendo de 0,3 a $0,8 \mathrm{~kg} \mathrm{t}^{-1}$.

Com relação aos micronutrientes, nota-se que o maior teor de $\mathrm{B}$ ocorreu nos tubérculos da cultivar Ágata, enquanto, o menor teor desse elemento foi observado na cultivar Atlantic (Tabela 42). Na exportação por área e por tonelada as cultivares Ágata e Asterix apresentaram os maiores valores, enquanto que, na exportação por tonelada o menor valor foi obtido na cultivar Mondial. Os valores de exportação por tonelada foram inferiores aos relatados por Yorinori (2003) que obteve valores da ordem de 1,99 $\mathrm{g} \mathrm{t}^{-1}$ (safra das águas) e $2,8 \mathrm{~g} \mathrm{t}^{-1}$ (safra das secas), no entanto, enquadram-se dentro do intervalo descrito por Fontes (1997b), que é de 0,6 a 1,5 $\mathrm{g} \mathrm{t}^{-1}$.

As cultivares apresentaram comportamento semelhante quanto ao teor e exportação de $\mathrm{Cu}$ por área, sendo que os maiores valores foram obtidos em Mondial e o menores em Ágata e Atlantic (Tabela 42). A exportação de $\mathrm{Cu}$ por tonelada foi maior nas cultivares Markies e Mondial e menor na cultivar Ágata. As cultivares Ágata e Atlantic apresentaram exportação de $\mathrm{Cu}$ por área inferior à relatada por Yorinori (2003) que foi de $31 \mathrm{~g}$ $\mathrm{ha}^{-1}$ (safra das águas) e $35 \mathrm{~g} \mathrm{ha}^{-1}$ (safra das secas). No entanto, apenas as cultivares Markies e Mondial apresentaram exportação por tonelada de tubérculos dentro da faixa relatada por Fontes (1997b) que segundo esse autor fica entre 1,3 e 2,0 $\mathrm{g} \mathrm{t}^{-1}$.

Somente a cultivar Markies apresentou teor de $\mathrm{Fe}$ inferior ao observado nas demais cultivares, enquanto que, a exportação desse elemento tanto por área como por unidade produzida não diferiu entre as cultivares (Tabela 42). No entanto, em todas as cultivares a exportação por hectare foi menor que a obtida por Yorinori (2003), que foi de $392 \mathrm{~g} \mathrm{ha}^{-1}$ (safra das águas)e $358 \mathrm{~g} \mathrm{ha}^{-1}$ (safra das secas). 
Tabela 42. Teor, exportação por área e por tonelada de tubérculos dos micronutrientes $\mathrm{B}, \mathrm{Cu}$, $\mathrm{Fe}, \mathrm{Mn}$ e $\mathrm{Zn}$, nas cultivares de batata na colheita final.

\begin{tabular}{|c|c|c|c|c|c|}
\hline Cultivares & $\mathrm{B}$ & $\mathrm{Cu}$ & $\mathrm{Fe}$ & $\mathrm{Mn}$ & $\mathrm{Zn}$ \\
\hline & \multicolumn{5}{|c|}{$\mathrm{mg} \mathrm{kg}^{-1}$ de $\mathrm{MS}^{(1)}$} \\
\hline Ágata & $8 a$ & $4 \mathrm{~b}$ & $56 a$ & $12 \mathrm{ab}$ & $22 \mathrm{a}$ \\
\hline Asterix & $7 \mathrm{ab}$ & $7 b c$ & $47 a$ & $8 b$ & $25 \mathrm{a}$ \\
\hline Atlantic & $5 b$ & $4 b$ & $57 \mathrm{a}$ & $9 b$ & $19 \mathrm{a}$ \\
\hline Markies & $6 a b$ & $11 \mathrm{ab}$ & $27 b$ & $13 \mathrm{a}$ & $22 \mathrm{a}$ \\
\hline Mondial & $6 a b$ & $14 \mathrm{a}$ & $43 a$ & $10 \mathrm{ab}$ & $20 \mathrm{a}$ \\
\hline \multirow{2}{*}{$\mathrm{CV} \%$} & 18,0 & 37,9 & 38,2 & 18,5 & 18,1 \\
\hline & \multicolumn{5}{|c|}{$\mathrm{g} \mathrm{ha}^{-1(2)}$} \\
\hline Ágata & $43 \mathrm{a}$ & $20 \mathrm{~b}$ & $296 \mathrm{a}$ & $62 \mathrm{ab}$ & $114 \mathrm{ab}$ \\
\hline Asterix & $48 \mathrm{a}$ & $46 a b$ & $309 a$ & $51 \mathrm{ab}$ & $167 \mathrm{a}$ \\
\hline Atlantic & $22 b$ & $16 b$ & $241 \mathrm{a}$ & $37 \mathrm{~b}$ & $83 b$ \\
\hline Markies & $30 \mathrm{~b}$ & $54 \mathrm{ab}$ & $131 \mathrm{a}$ & $65 \mathrm{a}$ & $110 \mathrm{~b}$ \\
\hline Mondial & $30 \mathrm{~b}$ & $79 \mathrm{a}$ & $237 \mathrm{a}$ & $54 \mathrm{ab}$ & $110 \mathrm{~b}$ \\
\hline \multirow[t]{2}{*}{$\mathrm{CV} \%$} & 13,6 & 46,5 & 44,5 & 21,4 & 21,2 \\
\hline & \multicolumn{5}{|c|}{$\mathrm{g} \mathrm{t}^{-1}$ de matéria fresca ${ }^{(2)}$} \\
\hline Ágata & $1,17 \mathrm{a}$ & $0,52 b$ & $7,92 \mathrm{a}$ & $1,67 \mathrm{ab}$ & $3,07 \mathrm{a}$ \\
\hline Asterix & $1,20 \mathrm{a}$ & $1,15 \mathrm{ab}$ & $7,80 \mathrm{a}$ & $1,30 \mathrm{~b}$ & $4,17 \mathrm{a}$ \\
\hline Atlantic & $1,00 \mathrm{ab}$ & $0,75 \mathrm{ab}$ & $10,77 \mathrm{a}$ & $1,62 \mathrm{ab}$ & $3,70 \mathrm{a}$ \\
\hline Markies & $1,02 \mathrm{ab}$ & $1,90 \mathrm{a}$ & $4,57 \mathrm{a}$ & $2,27 \mathrm{a}$ & $3,82 \mathrm{a}$ \\
\hline Mondial & $0,72 b$ & $1,92 \mathrm{a}$ & $5,77 \mathrm{a}$ & $1,35 b$ & $2,70 \mathrm{a}$ \\
\hline CV \% & 15,9 & 43,2 & 40,5 & 22,6 & 19,9 \\
\hline
\end{tabular}

Médias seguidas de mesma letra nas colunas não diferem entre si pelo teste Tukey a 5\% de probabilidade.

${ }^{(1)}$ Valores expressos na matéria seca. ${ }^{(2)}$ Exportação de nutrientes em relação à produtividade total.

A cultivar Markies apresentou o maior teor de Mn e, os menores teores foram obtidos nos tubérculos das cultivares Asterix e Atlantic (Tabela 42). Quanto a exportação de Mn por área os maiores valores foram observados na cultivar Markies e os menores na Atlantic. Na exportação por tonelada, a cultivar Markies sobressaiu em relação às demais, enquanto os menores valores foram observados em Asterix e Mondial. Yorinori (2003) obteve exportação por área de $28 \mathrm{~g} \mathrm{ha}^{-1}$ (safra das águas) e 16,5 $\mathrm{g} \mathrm{ha}^{-1}$ (safra das secas), as quais foram inferiores a observada em todas as cultivares. No entanto, a exportação por tonelada de tubérculos apresentada pela cultivar Markies foi superior ao intervalo descrito por Fontes (1997b) (1,7 a 2,1 $\mathrm{g} \mathrm{t}^{-1}$ ), enquanto que nas demais cultivares os valores de exportação foram inferiores aos citados pelo referido autor.

Os teores de $\mathrm{Zn}$, bem como a exportação desse elemento por tonelada de tubérculos, não apresentaram diferença entre as cultivares (Tabela 42). No entanto, as cultivares Atlantic, Markies e Mondial apresentaram as menores exportações por área. 
Yorinori (2003) obteve exportação por área de 97,2 $\mathrm{g} \mathrm{ha}^{-1}$ (safra das secas) e 91,5 $\mathrm{g} \mathrm{ha}^{-1}$ (safra das águas), as quais foram superiores apenas à obtida para a mesma cultivar, neste trabalho. Apenas na cultivar Mondial a exportação por tonelada de tubérculos ficou abaixo dos valores relatados por Fontes (1997b) que são de 3,0 a 5,0 $\mathrm{g} \mathrm{t}^{-1}$.

\subsection{Relações entre crescimento, marcha de absorção e a prática de adubação}

Conforme notou-se pelos dados apresentados, as plantas de todas as cultivares apresentaram o máximo crescimento entre 59 e 69 DAP, enquanto que os tubérculos tiveram crescimento intenso um pouco depois, entre os 62 e 75 DAP. Observou-se que mesmo havendo diferenças entre as quantidades de nutrientes absorvidas pelas cultivares, existe uma época crítica, em que todas as cultivares necessitam de praticamente todos os nutrientes disponíveis em quantidades relativamente altas, que é, principalmente, no início da fase de enchimento de tubérculos, ou seja, de 42 até 62 DAP. Vale ressaltar ainda, que mesmo apresentando variações entre as cultivares, normalmente, a época de maior demanda por nutrientes ocorreu um pouco antes ou coincidiu com a época em que as plantas atingiram a máxima produção de MS. Estudos realizados por Greef et al. (1999) com N em milho, demonstraram comportamento semelhante a esse, em que o autor relata que as taxas máximas de absorção de $\mathrm{N}$ ocorreram em média de 7 a 13 dias antes das plantas atingirem as taxas máximas de crescimento. No entanto, esse comportamento não foi observado para todos os nutrientes, uma vez que os micronutrientes $\mathrm{Cu}$ e $\mathrm{Zn}$ tiveram a maior parte da absorção entre o final da fase de enchimento de tubérculos e durante a fase de maturação, ou seja, dos 63 aos 97 DAP.

Entre os macronutrientes, verificou-se que o $\mathrm{K}$, seguido do $\mathrm{N}$ foram os elementos absorvidos em maiores quantidades pelas plantas, enquanto, os demais foram absorvidos em quantidades bem menores, obedecendo a seguinte ordem: $\mathrm{Ca}>\mathrm{P}>\mathrm{Mg}>\mathrm{S}$. Em média as cultivares extraíram em torno de 204, 102, 41, 16, 11 e $8 \mathrm{~kg} \mathrm{ha}^{-1}$ de $\mathrm{K}, \mathrm{N}, \mathrm{Ca}, \mathrm{P}, \mathrm{Mg}$ e $\mathrm{S}$, respectivamente. As quantidades exportadas de macronutrientes pelos tubérculos, em todas as cultivares obedeceram a seguinte seqüência: $\mathrm{K}>\mathrm{N}>\mathrm{P}>\mathrm{Mg}>\mathrm{S}>\mathrm{Ca}$; com valores médios de exportação pelos tubérculos de aproximadamente 176, 67, 13, 7, 5 e 2 kg ha-1, respectivamente. Em torno de $86 \%$ do total de $\mathrm{K}$ e $83 \%$ do total de $\mathrm{P}$ extraídos pelas plantas 
das cultivares de batata foram aparentemente exportados pelos tubérculos. Para os elementos $\mathrm{N}, \mathrm{Mg}$ e S essa proporção foi menor e ficou entre $66 \%$ e $61 \%$ do total extraído. No entanto, para o $\mathrm{Ca}$ apenas $6 \%$ das quantidades totais máximas extraídas, foram exportadas pelos tubérculos. $\mathrm{O} \mathrm{Ca}$ apesar de ser o terceiro macronutriente mais absorvido pela batateira, é o menos exportado pelos tubérculos, o que torna fundamental que esse elemento esteja disponível em níveis adequados no solo, durante a formação e o crescimento dos tubérculos, pois a translocação desse nutriente para os tubérculos é baixa. Quando se trata de produção de tubérculos-semente a disponibilidade desse elemento no solo torna-se ainda mais importante, pois, segundo Magalhães (1985) há evidências de que a baixa reserva de Ca nos tubérculossemente afeta a brotação e o vigor dos brotos, podendo mesmo levá-los a morte antes do plantio.

Quanto à extração de micronutrientes observou-se a seguinte seqüência: $\mathrm{Fe}>\mathrm{Mn}>\mathrm{Zn}>\mathrm{Cu}>\mathrm{B}$, com valores médios de 1.885, 540, 335, 101 e $58 \mathrm{~g} \mathrm{ha}^{-1}$, respectivamente. A exportação pelos tubérculos obedeceu a seguinte ordem nas cultivares Ágata, Asterix e Atlantic: $\mathrm{Fe}>\mathrm{Zn}>\mathrm{Mn}>\mathrm{B}>\mathrm{Cu}$, respectivamente, com valores médios exportados de 282, 121, 54, 35 e $27 \mathrm{~g} \mathrm{ha}^{-1}$. Nas cultivares Markies e Mondial observou-se alteração na ordem de exportação, e o $\mathrm{Cu}\left(67 \mathrm{~g} \mathrm{ha}^{-1}\right)$ foi mais exportado do que $\mathrm{B}\left(30 \mathrm{~g} \mathrm{ha}^{-1}\right)$. De maneira geral, aproximadamente $60 \%$ do total de B extraído pelas cultivares de batata foram exportados pelos tubérculos. Os nutrientes $\mathrm{Cu}$ e $\mathrm{Zn}$ apresentaram valores intermediários com exportação de $43 \%(\mathrm{Cu})$ e $35 \%$ (Zn) da extração total. No entanto, as menores proporções foram observadas para os micronutrientes $\mathrm{Fe}$ e $\mathrm{Mn}$, com valores ao redor de $13 \%$ e 10\%, respectivamente.

A cultivar Mondial apresentou a maior extração de $\mathrm{K}, \mathrm{Ca}$ e $\mathrm{Mg}$ enquanto a cultivar Asterix apresentou a maior extração de $\mathrm{N}$, sendo estas as cultivares mais produtivas. Mesmo a cultivar Ágata tendo apresentado produtividade semelhante a Asterix, a quantidade de $\mathrm{K}$ e Mg extraída por essa cultivar foi inferior à das demais.

A cultivar Asterix apresentou a maior exportação de $\mathrm{N}, \mathrm{P}, \mathrm{K}$ e $\mathrm{Mg}$, enquanto que a maior exportação de Ca foi observada na Mondial. Com exceção do S, para os demais macronutrientes a cultivar Atlantic apresentou as menores exportações. Embora a cultivar Ágata tenha apresentado a menor extração de $\mathrm{Mg}$ e a segunda menor extração de $\mathrm{N}$, essa cultivar foi uma das que mais exportou esses elementos pelos tubérculos. 
Quanto aos micronutrientes, a cultivar Mondial extraiu as maiores quantidades de $\mathrm{Fe}$ e, juntamente com Asterix, extraíram as maiores quantidades de Mn, Zn e $\mathrm{B}$, enquanto, apenas a cultivar Asterix apresentou a alta extração de $\mathrm{Cu}$. As maiores exportações de $\mathrm{Fe}, \mathrm{Zn}$ e B foram observadas nas cultivares Asterix e Ágata. A cultivar Mondial apresentou as maiores exportações de $\mathrm{Cu}$.

De maneira geral, notou-se que a cultivar Mondial que apresentou elevada produtividade, normalmente, foi mais exigente em termos extração, porém, apresentou baixa exportação, diferente da cultivar Ágata que apresentou na maioria das vezes extração inferior as observadas na Mondial e Asterix, mas proporcionou altas exportações. Asterix teve comportamento diferente dessas cultivares, apresentando tanto extração como exportação relativamente alta em comparação às demais cultivares.

Quanto ao manejo da adubação adotado, deve-se considerar que cultivou-se a cultura em solo com elevada acidez, baixa saturação por bases, e teores de macro e micronutrientes considerados altos, exceção feita apenas ao $\mathrm{Mg}$, que estava em um teor médio no solo (Tabela 1). Além disso, foram aplicados $2.100 \mathrm{~kg} \mathrm{ha}^{-1}$ do formulado 4-30-10 no sulco de plantio e $227 \mathrm{~kg} \mathrm{ha}^{-1}$ do formulado 20-05-20 em cobertura aos 29 DAP, antecedendo a amontoa. No total, aplicou-se $129 \mathrm{~kg} \mathrm{ha}^{-1}$ de N, $280 \mathrm{~kg} \mathrm{ha}^{-1}$ de P e $213 \mathrm{~kg} \mathrm{ha}^{-1} \mathrm{de}$ K. Observou-se que a maior extração de $\mathrm{N}$ foi obtida na cultivar Asterix que absorveu $117 \mathrm{~kg} \mathrm{ha}^{-1}$ de $\mathrm{N}$, o que demonstra que, sem considerar perdas de $\mathrm{N}$ do sistema a quantidade aplicada via adubação foi próxima da máxima extração apresentada pelas cultivares.

No entanto, quando essa relação é feita para o $\mathrm{P}$, nota-se, que o teor inicial desse elemento no solo encontrava-se alto, em torno de $70 \mathrm{mg} \mathrm{dm}^{-3}$, e as cultivares que mais extraíram esse elemento foram Asterix e Mondial, com extração de $18 \mathrm{~kg} \mathrm{ha}^{-1}$. Não levando em conta o processo de fixação desse elemento no solo, que sabidamente ocorre, e o P já presente no solo antes da adubação de plantio, observa-se que em média a absorção de $\mathrm{P}$ foi 16 vezes menor que a quantidade aplicada, ou seja, as cultivares que mais absorveram $\mathrm{P}$ extraíram apenas $6,4 \%$ de todo o $\mathrm{P}$ aplicado. Comportamento semelhante foi observado por Yorinori (2003), uma vez que em solos com teores de P considerados altos (103 mg de $\mathrm{P}_{\text {resina }}$ $\mathrm{dm}^{-3}$ de solo) e com a aplicação de $643 \mathrm{~kg} \mathrm{ha}^{-1}$ de $\mathrm{P}_{2} \mathrm{O}_{5}$ (por volta de $281 \mathrm{~kg} \mathrm{ha}^{-1}$ de P) a absorção do nutriente pela batateira foi de $15,2 \mathrm{~kg} \mathrm{ha}^{-1}$ de $\mathrm{P}$ e representou por volta de $5,4 \%$ do $\mathrm{P}$ aplicado via adubação. 
Já para o $\mathrm{K}$ as maiores extrações foram de 230 e $256 \mathrm{~kg} \mathrm{ha}^{-1}$ respectivamente, nas cultivares Asterix e Mondial. Assim, os $213 \mathrm{~kg} \mathrm{ha}^{-1}$ de $\mathrm{K}$ aplicados via adubação não foram suficientes para suprir as exigências totais dessas cultivares, as quais

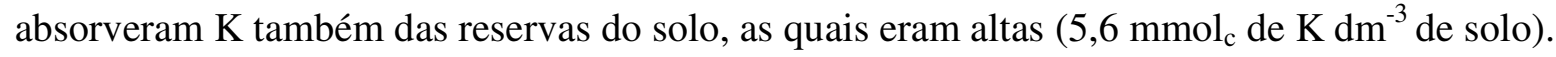

Assim fica claro que, principalmente, na adubação fosfatada, foi aplicado quantidade bem acima da necessidade da cultura, o que além de aumentar o custo de produção, pode gerar problemas ambientais. 


\section{CONCLUSÕES}

Todas as cultivares tiveram crescimento lento até o início da fase de enchimento de tubérculos. Desta época até o final do ciclo ocorreu o desenvolvimento dos tubérculos, com a máxima taxa de acúmulo de MS concentrando-se no início dessa fase.

A cultivar Mondial foi mais tardia em acumular MS, apresentando as maiores taxas de crescimento na fase final do ciclo.

As cultivares Ágata, Atlantic e Markies apresentam crescimento semelhante durante todo o ciclo, porém a cultivar Ágata, foi mais produtiva.

As cultivares Asterix e Mondial apresentaram maior acúmulo de MS, maior produtividade de tubérculos e maior extração de nutrientes do solo.

A cultivar Asterix apresentou alta extração e exportação de nutrientes, enquanto, a cultivar Mondial obteve alta extração, porém, menor exportação de nutrientes quando comparada à Ágata.

A época de maior taxa de absorção de nutrientes em todas as cultivares ocorreu no início da fase de enchimento de tubérculos, coincidindo, com a época de maior taxa de produção de MS.

Os nutrientes $\mathrm{Cu}$ e $\mathrm{Zn}$ foram mais absorvidos na fase final de enchimento de tubérculos e durante a fase de maturação. 
A sequiência de extração de nutrientes, em todas as cultivares, foi: $\mathrm{K}>$ $\mathrm{N}>\mathrm{Ca}>\mathrm{P}>\mathrm{Mg}>\mathrm{S}>\mathrm{Fe}>\mathrm{Mn}>\mathrm{Zn}>\mathrm{Cu}>\mathrm{B}$.

A seqüência de exportação de nutrientes foi: $\mathrm{K}>\mathrm{N}>\mathrm{P}>\mathrm{Mg}>\mathrm{S}>\mathrm{Ca}$ $>\mathrm{Fe}>\mathrm{Zn}>\mathrm{Mn}>\mathrm{B}>\mathrm{Cu}$. Nas cultivares Markies e Mondial o $\mathrm{Cu}$ foi mais exportado que o $\mathrm{B}$.

Das quantidades totais de macronutrientes extraídas pelas plantas das cultivares de batata, aproximadamente $86 \%, 66 \%, 6 \%, 83 \%, 62 \%$ e $61 \%$, respectivamente do $\mathrm{K}, \mathrm{N}, \mathrm{Ca}, \mathrm{P}, \mathrm{Mg}$ e $\mathrm{S}$ foram exportados pelos tubérculos.

Para os micronutrientes as quantidades exportadas pelos tubérculos representaram em torno de $13 \%, 35 \%, 10 \%, 60 \%$ e $43 \%$ do total extraído dos elementos $\mathrm{Fe}$, $\mathrm{Zn}, \mathrm{Mn}, \mathrm{B}$ e $\mathrm{Cu}$, respectivamente. 


\section{REFERÊNCIAS BIBLIOGRÁFICAS}

ABBA - ASSOCIAÇÃO BRASILEIRA DA BATATA. Variedades. Disponível em: <http://www.abbabatatabrasileira.com.br/2008/variedades.asp>. Acesso em: 16 dez. 2009.

AERTS, R. Nutrient resorption from senescing leaves of perennials: Are thre general patterns? Journal of Ecology, v.84, n.4, p.597-608, 1996.

AGRIANUAL - ANUÁRIO DA AGRICULTURA BRASILEIRA. Batata. São Paulo: FNP, 2009. 497p.

AGUIAR NETTO, A.O.; RODRIGUES, J.D.; PINHO, S.Z. Análise de crescimento na cultura da batata submetida a diferentes lâminas de irrigação. Pesquisa Agropecuária Brasileira, v.35, n.5, p.901-907, 2000.

ANDA - ASSOCIAÇÃO NACIONAL PARA DIFUSÃO DOS ADUBOS. Anuário Estatístico. São Paulo: ANDA, 2000. 252p.

ANDRIOLO, J.L.; BISOGNIN, D.A.; PAULA, A.L.; PAULA, F.L.M.; GODOI, R.S.; BARROS, G.T. Curva crítica de diluição de nitrogênio da cultivar Asterix de batata. Pesquisa Agropecuária Brasileira, v.41, n.7, p.1179-1184, 2006.

BARCELOS, D.M.; GARCIA, A.; MACIEL JUNIOR, V.A. Análise de crescimento da cultura da batata submetida ao parcelamento da adubação nitrogenada em cobertura, em um latossolo vermelho-amarelo. Ciência e Agrotecnologia, v.31, n.1, p.21-27, 2007.

BEADLE, C.L. Plant growth analysis. In: COOMBS, J.; HALL, D.O.; LONG, S.P.; SCURLOCK, J.M. O. (eds.). Techniques in bioproductivity and photosynthesis. 2. ed. Oxford: Pergamon, 1987. p.20-25. 
BENINCASA, M.M.P. Análise de crescimento de plantas: noções básicas. $2^{\mathrm{a}}$ ed. Funep: Jaboticabal, 2003. 41p.

BEUKEMA, H.P.; ZAAG, D.E. van der. Introduction to potato production. Wageningen: Pudoc, 1990. 180p.

BIEMOND, H.; VOS, J. Effects of nitrogen onthe development and growth of potato plant. 2. The partitioning of dry matter, nitrogen and nitrate. Annals of Botany, v.70, n.1 p.37-45, 1992.

CALDIZ, D.O. Genetic improvement and association with physiological changes in the potato. In: SLAFER, G.A. (eds.). Genetic improvement of fields crops. New York: Marcell Dekker, 1994. p.361-411.

CAROLUS, R.L. Chemical estimations of the weekly nutrient level of a potato crop. American Potato Journal, v.14, n.5 p.141-153, 1937.

COGO, C.M.; ANDRIOLO, J.L.; BISOGNIN, D.A. GODOI, R.S.; BORTOLOTTO, O.C.; LUZ, G.L. Relação potássio-nitrogênio para o diagnóstico e manejo nutricional da cultura da batata. Pesquisa Agropecuária Brasileira, v.41, n.12, p.1781-1786, 2006.

DECHEN, A.R.; NACHTIGALL, G.R. Micronutrientes. In: FERNANDES, M.S. (eds.). Nutrição mineral de plantas. Viçosa-MG: Sociedade Brasileira de Ciência do Solo. 2006, p.328-352.

DUARTE, A.P.; KIEHL, J.C.; CAMARGO, M.A.F.; RECO, P.C. Acúmulo de matéria seca e nutrientes em cultivares de milho originárias de clima tropical e introduzidas de clima temperado. Revista Brasileira de Milho e Sorgo, v.2, n.3, p.1-20, 2003.

ELMA CHIPS. Manual de recomendações técnicas para produção da variedade Atlantic. 5.ed. Itu, 2000. 15p.

EMBRAPA - EMPRESA BRASILEIRA DE PESQUISA AGROPECUÁRIA. Centro Nacional de Pesquisa de Solos. Manual de métodos de análise de solo. 2. ed. Brasília: Embrapa-CNPS, 1997. 212p. (Documentos, 1).

EMBRAPA - EMPRESA BRASILEIRA DE PESQUISA AGROPECUÁRIA. Centro Nacional de Pesquisa de Solos. Sistema Brasileiro de Classificação dos Solos. Rio de Janeiro: Embrapa-CNPS, 1999. 412p.

EPPENDORFER, W.H.; EGGUM, B.O. Effects of sulfur, phosphorus, potassium, and water stress on dietary fiber fractions, starch, amino acids and on the biological value of potato protein. Plant Foods for Human Nutrition, v.45, n.4, p.299-313, 1994.

EPSTEIN, E.; BLOOM, A. Nutrição mineral de plantas: princípios e perspectivas. traduzido por NUNES, M.E.T. Londrina: Editora Planta, 2006. 401p. 
EZETA, F.N.; McCOLLUM, R.E. Dry-matter production and nutrient uptake and removal by Solanum andigena in the Peruvian Andes. American Potato Journal, v.49, n.4, p.151-163, 1972.
FAO - FOOD AND AGRICULTURE ORGANIZATION OF THE UNITED NATIONS. (Roma, Itália). FAOSTAT: Crops. Disponível em: <http://faostat.fao.org/site/567/DesktopDefault.aspx>. Acesso em: 08 dez. 2009.

FAVORETTO, P. Parâmetros de crescimento e marcha de absorção de nutrientes na produção de mini-tubérculos de batata cv. Atlantic. 2005. 98p. Dissertação (Mestrado em Agronomia/Fitotecnia) - Escola Superior de Agricultura Luiz de Queiroz, Piracicaba. 2005.

FAYAD, J.A. Absorção de nutrientes, crescimento e produção do tomateiro cultivado em condições de campo e estufa. 1998. 81p. Tese (Mestrado em Fitotecnia), Universidade Federal de Viçosa, Viçosa. 1998.

FELTRAN, J.C. Adubação mineral na cultura da batata e residual no feijoeiro. 2005. 112p. Tese (Doutorado em Agronomia/Agricultura), Universidade Estadual Paulista, Faculdade de Ciências Agronômicas, Botucatu. 2005.

FELTRAN, J.C. Determinação das características agronômicas, dos distúrbios fisiológicos, do estado nutricional da planta e da qualidade dos tubérculos em cultivares de batata (Solanum tuberosum L.). 2002. 106p. Dissertação (Mestrado em Agronomia/Agricultura), Universidade Estadual Paulista, Faculdade de Ciências Agronômicas, Botucatu. 2002.

FELTRAN, J.C.; LEMOS, L.B. Acúmulo de nutrientes na parte aérea e nos tubérculos em cultivares de batata (Solanum tuberosum L.). In: ENCONTRO NACIONAL DE PRODUÇÃO E ABASTECIMENTO DE BATATA, 11; SEMINÁRIO NACIONAL DE BATATA SEMENTE, 7., Uberlândia, 2001. Resumos expandidos... Uberlândia: ABBA, 2001. p.21-25.

FILGUEIRA, F.A.R. Novo manual de olericultura: agrotecnologia moderna na produção e comercialização de hortaliças. Viçosa: UFV, 2000. 402p.

FONTES, P.C.R. Calagem e adubação da cultura da batata. Informe Agropecuário, v.20, n.197, p.42-52, 1999.

FONTES, P.C.R. Preparo do solo, nutrição mineral e adubação da batateira. Viçosa: UFV, 1997a. 42p.

FONTES, P.C.R.; DIAS, E.N.; SILVA, D.J.H. Dinâmica do crescimento, distribuição de matéria seca na planta e produção de pimentão em ambiente protegido. Horticultura Brasileira, v.23, n.1, p.94-99, 2005.

FONTES, R.R. Preparo do solo e adubação de plantio. In: LOPES, C.A.; BUSO, J.A. (eds.). Cultivo da batata (Solanum tuberosum L.). Brasília: EMBRAPA/CNPH, 1997b. 35p. (Instruções técnicas, 8). 
FORTES, G.R.L.; PEREIRA, J.E.S. Classificação e descrição botânica. In: PEREIRA, A.S.; DANIELS, J. (eds.). O cultivo da batata na região sul do Brasil. Brasília: Embrapa Informação Tecnológica, 2003. p.53-143.

GARGANTINI, H.; BLANCO, G.; GALLO, J.R.; NÓBREGA, S.A. Absorção de nutrientes pela batatinha. Bragantia, v.22, n.22, p.267-289, 1963.

GAVA, G.J.C.; TRIVELIN, P.C.O.; OLIVEIRA, M.W.; PENATTI, C.P. Crescimento e acúmulo de nitrogênio em cana-de-açúcar cultivada em solo coberto ou não com palhada. Pesquisa Agropecuária Brasileira, v.36, n.11, p.1347-1354, 2001.

GREEF, J.M.; OTT, H.; WULFES, R.; TAUBE, F. Growth analysis of dry matter accumulation and $\mathrm{N}$ uptake of forage maize cultivars affected by $\mathrm{N}$ supply. Journal of Agricultural Science, v.132, n.1, p.31-43, 1999.

GUIMARÃES, R. J. Análise do crescimento e da quantificação de nutrientes em mudas de cafeeiro (Coffea arábica L.), durante seus estádios de desenvolvimento em substrato padrão. 1994. 113p. Dissertação (Mestrado em Agronomia), Escola Superior de Agricultura de Lavras, Lavras. 1994.

HAWKINS, A. Rate of absorption and translocation of mineral nutrients by potatoes in Aroostook County, Maine, and their relation to fertilizer practices. Journal of the American Society of Agronomy, v.38, n.8, p.667-681. 1946.

IBGE - INSTITUTO BRASILEIRO DE GEOGRAFIA E ESTATÍSTICA. Levantamento sistemático da produção agrícola: pesquisa mensal de previsão e acompanhamento de safras agrícolas no ano civil. Disponível em: $<$ http://www.ibge.gov.br/home/estatistica/indicadores/agropecuaria/lspa/default.shtm>. Acesso em 8 de dez. 2009.

JONES JUNIOR, J.B.; WOLF, B.; MILL, H.A. Plant analysis handbook. Georgia: MicroMacro Publishing, 1991. 213p.

KLEINKOPF, G.E.; WESTERMANN, D.T.; DWELLE, R.B. Dry matter production and nitrogen utilization by six potato cultivars. Agronomy Journal, v.73, n.5, p.799-802, 1981.

KRATZKE, M.G.; PALTA, J.P. Calcium accumulation in potato tubers: role of basal roots. Hortscience, v.21, n.4, p.1022-1024, 1986.

LOPES N.F.; OLIVIA M.O.; CARDOSO M.I.; GOMES M.M.S.; SOUZA V.F. Crescimento e conversão de energia solar em Phaseolus vulgaris submetido a três densidades de fluxo radiante e dois regimes hídricos. Revista Ceres, v.33, n.186, p.142-114, 1986.

LORENZI, J.O.; MONTEIRO, P.A.; MIRANDA FILHO, H.S.; RAIJ, B. van. Raízes e tubérculos. In: RAIJ, B. van.; CANTARELLA, H.; QUAGGIO, J.A.; FURLANI, A.M.C., (eds.). Recomendações de adubação e calagem para o Estado de São Paulo. Campinas: Instituto Agronômico de Campinas, 1997. p.221-229 (Boletim Técnico, 100). 
LUCCHESI, A.A. Utilização prática da análise de crescimento vegetal. Anais da Escola Superior de Agricultura Luiz de Queiroz, v.41, n.1/2, p.181-201, 1984.

MACEDO JUNIOR, E.K. Crescimento e produtividade de pepino (Cucumis sativus L) enxertado e não enxertado, submetido à adubação convencional em cobertura e fertirrigação, em cultivo protegido. 1998. 129p. Tese (Doutorado em Horticultura), Universidade Estadual Paulista, Faculdade de Ciências Agronômicas, Botucatu. 1998.

MACEDO, M.C.M.; HAAG, H.P.; GALLO, J.R. Nutrição mineral de hortaliças. XXI Absorção de nutrientes por cultivares nacionais de batatinha (Solanum tuberosum L.). Anais da ESALQ, v.34, n.1, p.179-229, 1977.

MAGALHÃES, A.C.N. Análise quantitativa do crescimento. In: FERRI, M.G. (eds.). Fisiologia vegetal. São Paulo: Edusp, 1979. v.1, p.331-349.

MAGALHÃES, J.R. Nutrição e adubação da batata. São Paulo: Nobel, 1985. 51p.

MAGGIO, M.A. Acúmulo de massa seca e extração de nutrientes por plantas de milho doce híbrido “Tropical”. 2006. 56p. Dissertação (Mestrado em Tecnologia da Produção Agrícola), Instituto Agronômico de Campinas, Campinas. 2006.

MALAVOLTA, E. Elementos de nutrição mineral de plantas. São Paulo: Agronômica Ceres, 1980. 251p.

MALAVOLTA, E. Manual de nutrição mineral de plantas. São Paulo: Agronômica Ceres, 2006. 638p.

MALAVOLTA, E., VITTI, G.C., OLIVEIRA, S.A. Avaliação do estado nutricional de plantas: princípios e aplicações. Piracicaba: Potafós, 1997. 308p.

MARSCHNER, H. Mineral nutrition of higher plants. 2 ed. London: Academic Press, 1995. 889 p.

MELO, P.C.T.; GRANJA, N.P.; MIRANDA FILHO, H.S.; SUGAWARA, A.C.; OLIVEIRA, R.F. Análise do crescimento da cultivar de batata Ágata. In: CONGRESSO BRASILEIRO DE OLERICULTURA, 43., 2003, Recife. Anais... CD-ROM 2004. Recife-PE: UFRPE, 2003. 4p.

MELO, P.E. Cultivares de batata potencialmente úteis para o processamento na forma de fritura no Brasil e manejo para obtenção de tubérculos adequados. Informe Agropecuário, v.20, n.197, p.112-119, 1999.

MEURER, E.J. Potássio. In: FERNANDES, M.S. (eds.). Nutrição mineral de plantas. Viçosa-MG: Sociedade Brasileira de Ciência do Solo, 2006. p.282-295.

MILTHORPE, F.L.; MOOREY, J. An introduction to crop physiology. Cambridge: Cambridge University Press, 1974. 201p. 
MORENA, I.; GUILLEN, A.; MORAL, L.F.G. Yield development in potatoes as influenced by cultivar and the timing and level of nitrogen fertilization. American Potato Journal, v.71, n.3, p.165-173, 1994.

NIVAP - NETHERLANDS POTATO CONSULTATIVE FOUNDATION. Netherlands catalogue of potato varieties. 2007. 287p.

OJALA, J.C.; STARK, J.C.; KLEINKOPF, G.E. Influence of irrigation and nitrogen management on potato yiled and quality. American Potato Journal, v.67, n.1, p.29-43, 1990.

OLIVEIRA, C.A.S. Potato crop growth as affected by nitrogen and plant density. Pesquisa Agropecuária Brasileira, v.35, n.5, p.939-950, 2000.

PÁDUA, J. G. Batata Markies uma cultivar versátil no campo e na mesa. Batata show. v.5, n.13, 2005.

PAULA, M.B.; FONTES, P.C.R., NOGUEIRA, F.D. Produção de matéria seca e absorção de macronutrientes por cultivares de batata. Horticultura Brasileira, v.4, n.1, p.10-16, 1986.

PEREIRA, A.S. Composição química, valor nutricional e industrialização. In: REIFSCHNEIDER, F.J.B. (eds.). Produção de batata. Brasília: Linha Gráfica. 1987. p.1228.

PEREIRA, E.M.S.; LUZ, J.M.Q.; MOURA, C.C. A batata e seus benefícios nutricionais. Uberlândia: EDUFU. 60p. 2005.

RADFORD, P.J. Growth analysis formula their use and abuse. Crop Science, v.7, n.42, p.171-175, 1967.

RAIJ, B. van.; ANDRADE, J.C.; CANTARELlA, H.; QUAGGIO, J.A. Análise química para avaliação da fertilidade de solos tropicais. Campinas: Instituto Agronômico, 2001. $284 p$.

RAIJ, B. van.; CANTARELLA, H.; QUAGGIO, J.A., FURLANI, A.M.C. Recomendação de adubação e calagem para o Estado de São Paulo. Campinas: Instituto Agronômico de Campinas, 1997. 285p. (Boletim Técnico, 100).

RAVEN, J.A. Short and long distance transport of boric acid in plants. New Physiology, v.84, n.2, p.231-249, 1980.

REIS JÚNIOR, R.A.; FONTES, P.C.R. Morfologia e partição de assimilados na batateira em função de época de amostragem e de doses de potássio. Pesquisa Agropecuária Brasileira, v.34, n.5, p.795-799, 1999.

REIS JUNIOR, R.A.; MONNERAT, P.H. Exportação de nutrientes nos tubérculos de batata em função de doses de sulfato de potássio. Horticultura Brasileira, v.19, n.3, p.360-364, 2001. 
REYES-CUESTA, R.; LOPES, N.F.; OLIVA, M.A.; FRANCO, A.A. Crescimento e conversão da energia solar em Phaseolus vulgares em função da fonte de nitrogênio. Revista Ceres, v.42, n.242, p.405-455, 1995.

RIBEIRO, J.D.R. Associativismo garante futuro do produtor de batatas. Informe Agropecuário, v.20, n.197, p.5-6, 1999.

ROBERTS, S.; DOLE, R.E. Potassium nutrition of potatoes. In: MUNSON, R.D. Potassium in agriculture. Madison: American Society of Agronomy, 1985. p.799-818.

ROBERTS, S.; DOLE, R.E. Potassium nutrition of potatoes. In: MUNSON, R.D. (eds.) Potassium in agriculture. Madison: American Society of Agronomy, 1985. p.799-818.

RODRIGUES, J.D.; RODRIGUES, S.D.; DELACHIAVE, M.E.A.; PEDRAS, J.F. BOARO, C.S.F.; ONO, E.O. Influência de diferentes níveis de cálcio em plantas de estilosantes (Stylosanthes guyanensis (aubl) sw. cv. cook), avaliados através de alguns parâmetros fisiológicos. Scientia Agricola, v.50, n.1, p.45-57, 1993.

SILVA, E.C.; SILVA FILHO, A.V.; ALVARENGA, M.A.R. Efeito residual da adubação da batata sobre a produção do milho-verde em cultivo sucessivo. Pesquisa Agropecuária Brasileira, v.35, n.11, p.2151-2155, 2000.

SILVA, T.O.; MENEZES, R.S.C.; TIESSEN, H.; SAMPAIO, E.V.S.B; SALCEDO, I.H. SILVEIRA, L.M. Adubação orgânica da batata com esterco e, ou, Crotalaria juncea. I Produtividade vegetal e estoque de nutrientes no solo em longo prazo. Revista Brasileira Ciência Solo, v.31, n.1, p.39-49, 2007.

SOUZA, Z.S. Ecofisiologia. In: PEREIRA, A.S.; DANIELS, J. (eds.). O cultivo da batata na região sul do Brasil. Brasilia: Embrapa Informação Tecnológica, 2003. p.80-105.

TAIZ, L.; ZEIGER, E. Fisiologia Vegetal. 3.ed. Porto Alegre: Artmed, 2004. 559p.

VILLAS BÔAS, R.L.; ANTUNES, C.L.; BOARETTO, A.E.; SOUSA, V.F. de.; DUENHAS, L.H. Perfil da pesquisa e emprego da fertirrigação no Brasil. In: FOLEGATTI, M. V. (coord.) Fertirrigação: flores, frutas e hortaliças. Guaíba: Agropecuária, 2001. v.2, cap.2, p.71-103.

WESTERMANN, D.T. Fertility Management. In: ROWE, R.C. (eds.). Potato health management. Minnesota: APS Press, 1993. p.77-86.

YORINORI, G.T. Curva de crescimento e acúmulo de nutrientes pela cultura da batata cv. 'Atlantic'. 2003. 66p. Dissertação (Mestrado em Agronomia/Solos e Nutrição de Plantas), Escola Superior de Agricultura Luiz de Queiroz, Piracicaba. 2003. 
9 APÊNDICE 

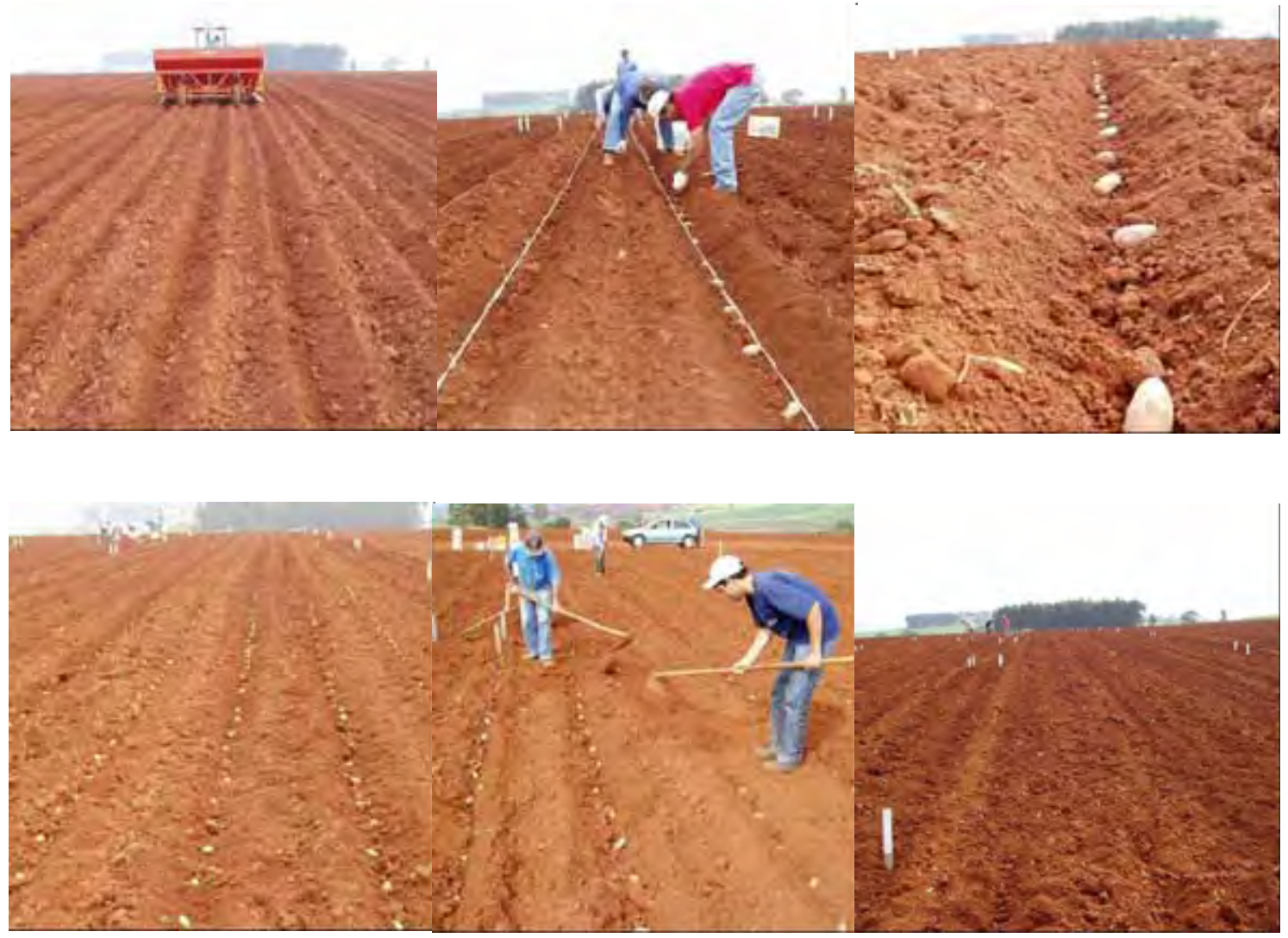

Apêndice 1. Instalação do experimento em junho de 2008. Estância Lago - Grupo Ioshida. 


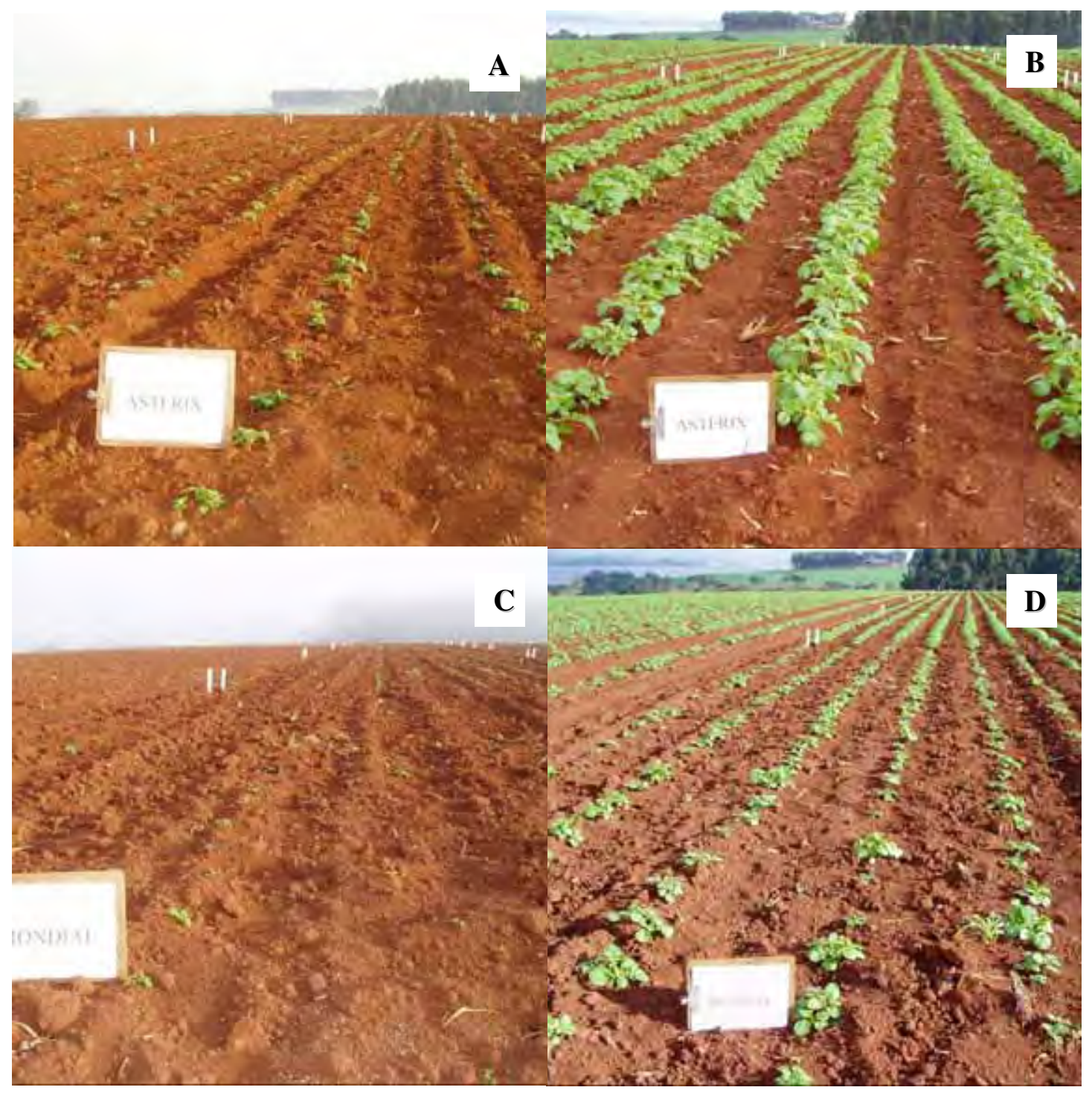

Apêndice 2. Visão geral do experimento: cultivar Asterix aos 20 DAP (A) e aos 27 DAP (B); cultivar Mondial aos 20 DAP (C) e aos 27 DAP (D). Estância Lago - Grupo Ioshida. 


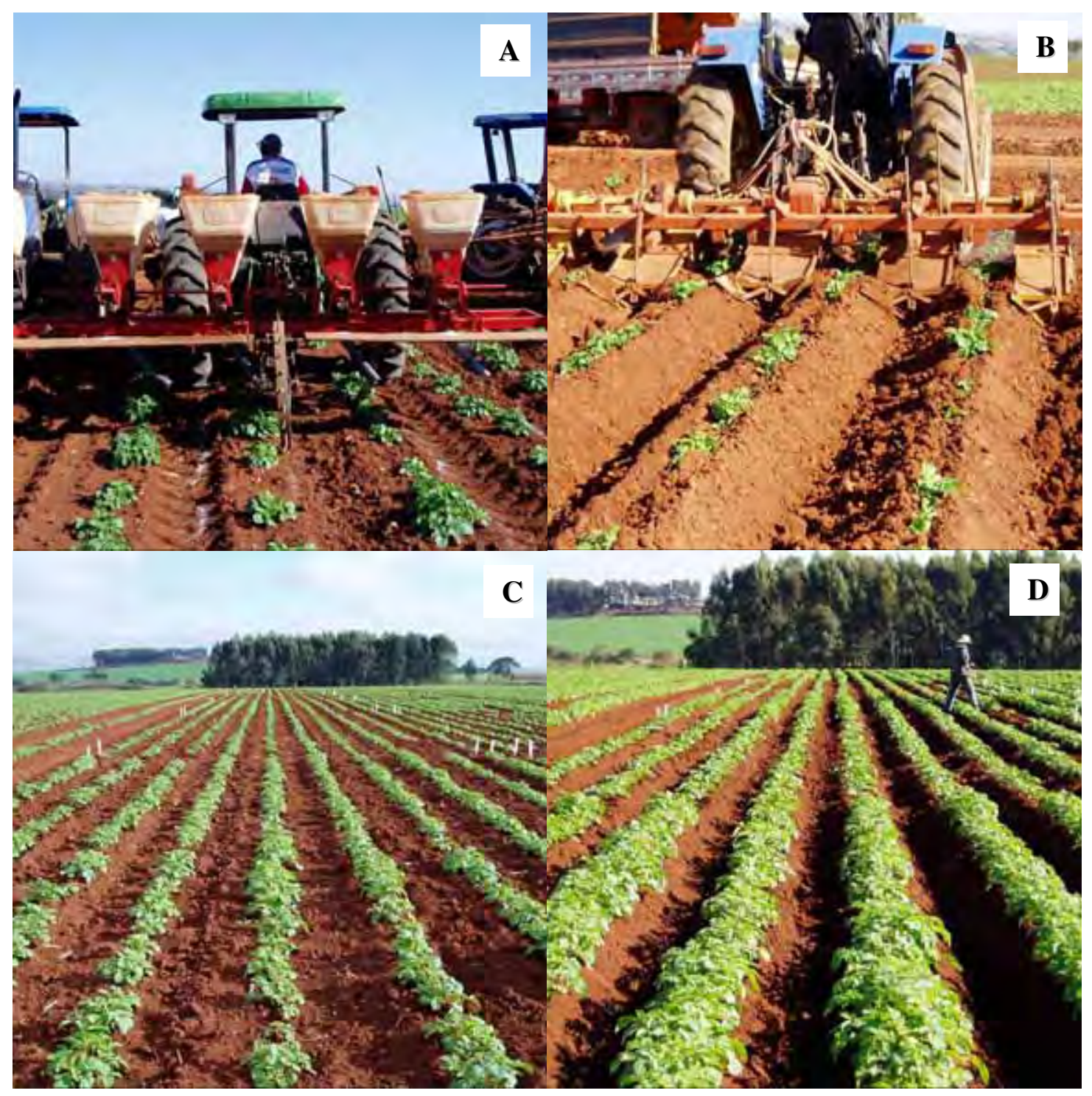

Apêndice 3. Adubação de cobertura (A) e amontoa (B) aos 29 DAP; visão geral do ensaio antes da amontoa aos 27 DAP (C) e depois da amontoa aos 34 DAP (D). 


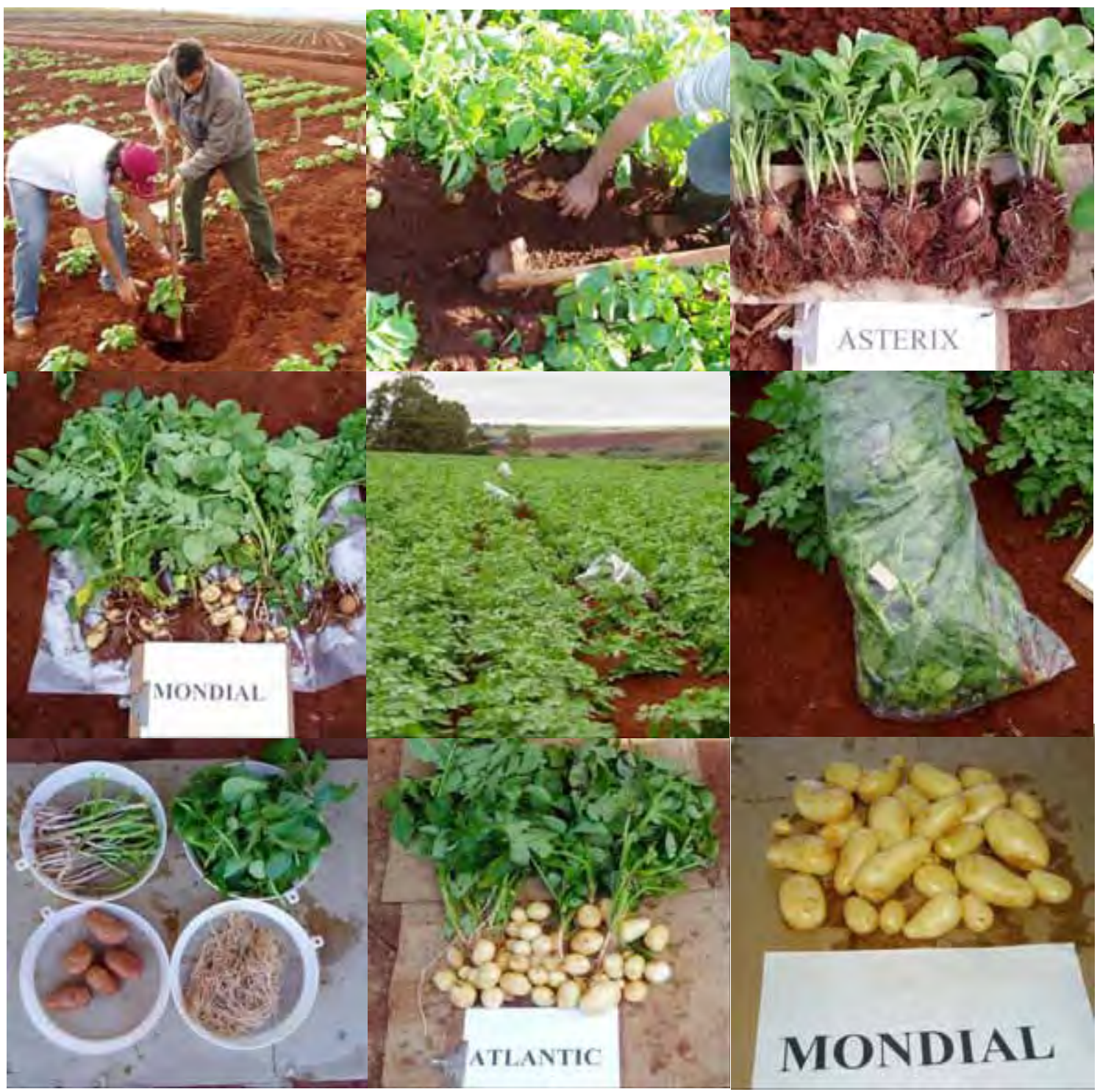

Apêndice 4. Metodologia de coleta de plantas e preparo das amostras durante a avaliação do experimento. 


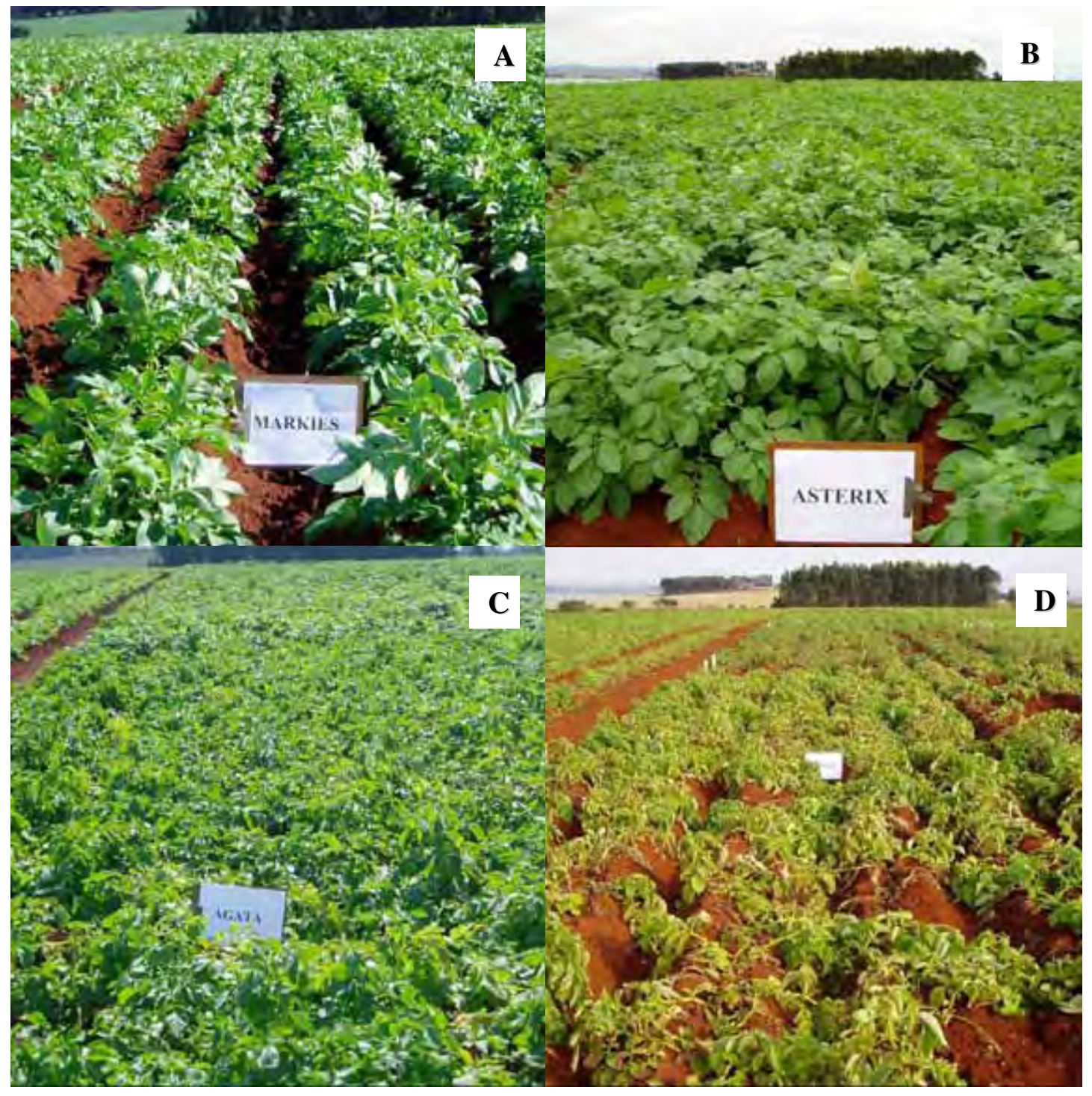

Apêndice 5. Visão geral do experimento: cultivar Markies aos 48 DAP (A), cultivar Asterix aos 62 DAP (B), cultivar Ágata aos 76 DAP (C) e cultivar Atlantic aos 97 DAP (D). Estância Lago - Grupo Ioshida. 